\title{
Charisma, Medieval and Modern
}

\author{
Edited by \\ Peter Iver Kaufman and Gary Dickson
}

Printed Edition of the Special Issue Published in Religions 
Peter Iver Kaufman and Gary Dickson (Eds.)

\section{Charisma, Medieval and Modern}


This book is a reprint of the special issue that appeared in the online open access journal Religions (ISSN 2077-1444) in 2012 (available at:

http://www.mdpi.com/journal/religions/special_issues/charisma_medieval).

\section{Guest Editors}

Peter Iver Kaufman

Jepson School, University of Richmond

Richmond, VA, USA

\section{Gary Dickson}

School of History, Classics, and Archaeology, University of Edinburgh

Edinburgh, EH, Scotland, UK

\section{Editorial Office}

MDPI AG

Klybeckstrasse 64

Basel, Switzerland

Publisher

Shu-Kun Lin

Production Editor

Jeremiah R. Zhang

\section{Edition 2014}

MDPI • Basel • Beijing

ISBN 978-3-03842-007-1

(C) 2014 by the authors; licensee MDPI, Basel, Switzerland. All articles in this volume are Open Access distributed under the Creative Commons Attribution 3.0 license (http://creativecommons.org/licenses/by/3.0/), which allows users to download, copy and build upon published articles even for commercial purposes, as long as the author and publisher are properly credited, which ensures maximum dissemination and a wider impact of our publications. However, the dissemination and distribution of copies of this book as a whole is restricted to MDPI, Basel, Switzerland. 


\section{Table of Contents}

List of Contributors V

Preface VII

\section{Gary Dickson}

Charisma, Medieval and Modern

Reprinted from: Religions 3 (2012): 763-789; doi:10.3390/rel3030763

http://www.mdpi.com/2077-1444/3/3/763

\section{Peter Iver Kaufman}

Augustine on Manichaeism and Charisma

Reprinted from: Religions 3 (2012): 808-816; doi:10.3390/rel3030808

http://www.mdpi.com/2077-1444/3/3/808

\section{Brett Edward Whalen}

Antichrist as (Anti)Charisma: Reflections on Weber and the 'Son of Perdition'

Reprinted from: Religions 4 (2013): 77-95; doi:10.3390/rel4010077

http://www.mdpi.com/2077-1444/4/1/77

\section{William M. Aird}

Saint Anselm of Canterbury and Charismatic Authority

Reprinted from: Religions 5 (2014): 90-108; doi:10.3390/rel5010090

http://www.mdpi.com/2077-1444/5/1/90 56

\section{Michael Clanchy}

Abelard: Celebrity and Charisma-A Response to Dickson

Reprinted from: Religions 3 (2012): 1140-1143; doi:10.3390/rel3041140

http://www.mdpi.com/2077-1444/3/4/1140

\section{Andrew Brown}

Charisma and Routine: Shaping the Memory of Brother Richard and Joan of Arc

Reprinted from: Religions 3 (2012): 1162-1179; doi:10.3390/rel3041162

http://www.mdpi.com/2077-1444/3/4/1162 


\section{Kristin M.S. Bezio}

Drama \& Demigods: Kingship and Charisma in Shakespeare's England

Reprinted from: Religions 4 (2013): 30-50; doi:10.3390/re14010030

http://www.mdpi.com/2077-1444/4/1/30

98

\section{George R. Goethals}

Charismatic Reactions to Individuals and Ideas: Looks, Language and Lincoln

Reprinted from: Religions 4 (2013): 209-215; doi:10.3390/rel4020209

http://www.mdpi.com/2077-1444/4/2/209

\section{Yaakov Ariel}

Charisma and Counterculture: Allen Ginsberg as a Prophet for a New Generation

Reprinted from: Religions 4 (2013): 51-66; doi:10.3390/rel4010051

http://www.mdpi.com/2077-1444/4/1/51

\section{Maiju Lehmijoki-Gardner}

Charisma, Diversity, and Religion in the American City- A Reflection

Reprinted from: Religions 5 (2014): 435-443; doi:10.3390/rel5020435

http://www.mdpi.com/2077-1444/5/2/435 


\section{List of Contributors}

William M. Aird lectures in Medieval History at the University of Edinburgh. His research interests concern the eleventh and twelfth centuries in Western Europe, with a focus on the 'Norman diaspora' in the British Isles, Northern France and Southern Italy. His more recent publications include: Duke Robert II, 'Curthose' of Normandy, c.1051-1134 (Boydell \& Brewer 2008) and The Tears of Bishop Gundulf: Gender, Religion, and Emotion in the Late Eleventh Century, in Cordelia Beattie and Kirsten A. Fenton, eds., Intersections of Gender, Religion and Ethnicity in the Middle Ages, (Palgrave Macmillan 2011), 62-84.

Yaakov Ariel is a graduate of the Hebrew University of Jerusalem and the University of Chicago, Yaakov Ariel's research focuses on Christian-Jewish relations, the Jewish reaction to modernity and postmodernity, and New Religious Movements. Ariel has published numerous articles and three books on these and other subjects. One of his books, Evangelizing the Chosen People (University of North Carolina Press 2000), was awarded the Albert C. Outler prize by the American Society of Church History. Ariel's latest book is An Unusual Relationship (New York University Press 2013). Ariel teaches Religious Studies at the University of North Carolina at Chapel Hill.

Kristin M.S. Bezio is an Assistant Professor of Leadership Studies at the Jepson School of Leadership Studies at the University of Richmond in Virginia. Her background is in technical theater and literature, and her research interests include early modern drama, leadership studies, and game studies. Recent publications include Subject, Servant, \& Sovereign: Servant Leadership and Elizabethan Government in Shakespeare's 'King John' in Leadership and Elizabethan Culture, 'Staged Magic: Performing Witchcraft in Macbeth' in William Shakespeare's Macbeth, and Friends \& Rivals: Loyalty, Ethics, and Leadership in 'Dragon Age II' in Identity and Leadership in Virtual Communities: Establishing Credibility and Influence.

Andrew Brown has been a senior lecturer in the School of Humanities at Massey University, Palmerston North (NZ) since 2010. Previously he was at Edinburgh University, and before that at Oxford as a Fellow at Keble College. His books include: Popular Piety in Late Medieval England: the Diocese of Salisbury 1250-1550 (OUP, 1995); Church and Society in England 1000-1500 (Palgrave, 2003); and Civic Ceremony and Religion in Bruges 1300-1520 (CUP, 2011).

Michael Clanchy is Emeritus Professor of Medieval History at the Institute of Historical Research, University of London, and a Fellow of the British Academy. He taught previously at the Univesity of Glasgow. He is the author of Abelard - A Medieval Life (Blackwell 1997) and From Memory to Written Record: England 1066-1307 (third edition, John Wiley \& Sons 2012). 
Gary Dickson was born in California. He received his A.B. at Stanford; his M.A. at Yale; and his Ph.D. from the University of Edinburgh. Employed as a medievalist in Edinburgh's history department for most of his academic career, he retired as a Reader and an Honorary Fellow. Medieval religious movements, revivalism, became the focus of his intellectual interest, as evidenced in his collected studies Religious Enthusiasm in the Medieval West: Revivals, crusades, saints (Ashgate 2000) and The Children's Crusade: Medieval History; Modern Mythistory (Palgrave-MacMillan 2008, pb 2010). His eight Wilde Lectures in Natural and Comparative Religion delivered at Oxford University (1996-7) were on the theme of 'Medieval Pentecostalism'. At present he is working on a book based on these lectures.

George R. Goethals holds the E. Claiborne Robins Distinguished Professorship in Leadership Studies at the University of Richmond. Previously at Williams College he served as chair of the Department of Psychology, founding chair of the Program in Leadership Studies, and Provost. With Georgia Sorenson and James MacGregor Burns, he edited the Encyclopedia of Leadership (Sage Publications 2004). With Gary McDowell he edited Lincoln's Legacy of Leadership (Palgrave Macmillan 2009). With Scott Allison he coauthored Heroes: What They Do \& Why We Need Them (Oxford University Press 2011) and Heroic Leadership: An Influence Taxonomy of 100 Exceptional Individuals (Routledge 2013). Goethals recent scholarship explores presidential leadership and race relations.

Maiju Lehmijoki-Gardner, Ph.D., is a church historian and a registered nurse. She is Coordinator of Health Professions Counseling and Affiliate Theology Professor at Loyola University Maryland. Her published work has focused on medieval spirituality and religious dietary ethics. Her publications include Dominican Penitent Women (Paulist Press 2005), an edition of medieval sources concerning Dominican laywomen, and the article Writing Religious Rules as an Interactive Process - Dominican Penitent Women and the Making of Their Regula, published in Speculum 79 (July 2004). As a registered nurse she is actively involved in urban health promotion through research, teaching, service-learning partnerships, urban school wellness initiatives, and Loyola University Maryland's outreach.

Peter Iver Kaufman is Professor Emeritus at the University of North Carolina, Chapel Hill, and George Matthews and Virginia Brinkley Modlin Distinguished Professor at the University of Richmond. His latest books, Religion around Shakespeare (authored) and Leadership and Elizabethan Culture (edited) appeared in 2013. His previous work on Augustine appeared in Incorrectly Political: Augustine and Thomas More (2007) and, since then, in several journals including History of Political Thought, Journal of Late Antiquity, Journal of Religious Ethics, and Vigiliae Christianae. He is Editor-in-Chief of Religions.

Brett Whalen teaches medieval European history at UNC-Chapel Hill. His other works include Dominion of God: Christendom and Apocalypse in the Middle Ages (Harvard University Press 2009) and The Medieval Papacy (Palgrave Macmillan 2014). He is currently writing a book about papal sovereignty in the thirteenth century. 


\section{Preface}

What is striking about this collection is that all the writers testify to one fact- the extraordinary fruitfulness of Max Weber's idea of charisma. Proof of the capaciousness of the Weberian idea of charisma is its diffusion outside the academic community, although "charisma" as popularized by the media owes little to Weber. These articles reveal, however, that Weberian charisma is indeed relevant to an astonishing range of phenomena. The expansion of charisma's territory stretches beyond what Max Weber could have imagined.

The central theme of my introductory essay is Max Weber's concept of charisma and its ramifications medieval and modern. The medieval dramatis personae range from the eleventh-century preacher of the first crusade, Peter the Hermit, to the late-fifteenth-century Florentine demagogue Girolamo Savonarola. The moderns include the demagogic radio priest Father Coughlin (d.1979) as well as the sect leaders Jim Jones of Jonestown (d. 1978) and David Koresh of the Branch Davidians (d. 1993), both of whom died ingloriously. Living saints present a final contrast.

Chronologically first comes Peter Kaufman's understanding of why, in late fourth and early fifth-century Roman North Africa and Italy, St. Augustine became disenchanted and disillusioned with the supposedly elite leaders of the Manichees. Instead, he came to value more humble Christians, specifically the early Christian martyrs. Augustine's charismatics were dead rather than alive.

From early Christianity to Barack Obama, Brett Whalen looks apocalpticism's Antichrist as the possessor of a 'dark charisma'. Adso, the tenth-century biographer of Antichrist has him born a Jew, his life a perverted parallel to Christ's. His power was anticharismatic. Apocalyptically-minded enemies of President Obama view him as a contemporary Antichrist, a false messiah.

William Aird concentrates on Saint Anselm of Canterbury (d.1109) and the charismatic authority he won as monk, abbot, miracle worker, preacher and scholar. Institutional and personal charisma secured his election as archbishop of Canterbury, although, ultimately, he lost his charismatic authority in exile, estranged from the king and abandoned by his followers.

Michael Clancy clarifies topics pertaining to one of the foremost philosophers of the twelfth century, Peter Abelard. Although Abelard did have student followers, it was Bernard of Clairvaux who fits the criteria of a charismatic teacher "rather better" than Abelard. Nonetheless, Abelard's celebrity status was widely acknowledged, as was his role as a public intellectual.

Andrew Brown examines the careers of Brother Richard, a charismatic apocalyptic preacher associated with Joan of Arc in fifteenth-century northern France.. While Richard was imprisoned and disappeared from the records, Joan was burnt at the stake. Her charisma culminated in canonization (1920). The focus of Brown's analysis is the Weberian distinction between charisma and routinization. 
Kristin Bezio takes us to late sixteenth century England and considers Shakespeare as a dramatist of royal charisma and its loss. This is an erudite discussion of the limitations of royal charisma which in England fused spiritual endowment with military success. The failure of royal charisma demonstrates frailty.

Social psychologist George Goethals opens his essay on Lincoln's presidential charisma (1861-65) with comments on Franklin Delano Rooesvelt's wish not to be photographed in his wheel chair. FDR wanted nothing to diminish his image as a strong leader. According to Goethals, Lincoln's "emotional connection with his followers" was created by means of his appearance and visibility. Biblical rhetoric in his speeches added to his charisma.

Yaakov Ariel chooses the poet Allen Ginsberg, as prophet and "father figure" of the Beat Generation (1950s-1990s). So he was a "charismatic counter-leader." His aura grew with the aura of the Beats, for whom he was a quasi-leader, even if his generation eschewed "rigid structures and authorities." His poems Howl and Kaddish brought him fame.

Maiju Lehmijoki-Gardner's vivid account of her exploration of Pentecostalist AfricanAmerican charismatic leadership, preaching, and worship in twenty-first century Baltimore, conjoins the issues of urban poverty, health, and racial and gender discrimination. The role of religion is also noted in the Webers' journey to America. Dr. Lehmijoki-Gardner's findings are enhanced by her personal perspective.

The editors would like to thank their contributors whose enthusiasm and erudition energized and inspired us, as did our collegue Jeremiah Zhang's cooperation at every stage from concept to journal to book.

Gary Dickson

Guest Editor 
Reprinted from Religions. Cite as: Dickson, G. "Charisma, Medieval and Modern." Religions 3 (2012): 763-789.

\title{
Charisma, Medieval and Modern
}

\section{Gary Dickson}

\begin{abstract}
Popularized by the mass media, Max Weber's sociological concept of charisma now has a demotic meaning far from what Weber had in mind. Weberian charismatic leaders have followers, not fans, although, exceptionally, fans mutate into followers. This essay aims to trace some of the dimensions of Weberian charismatic religious leadership in comparative perspective, medieval and modern. Examples include: preachers, "double charisma," professors, "collective charisma," religious radicals, the economy of charisma, transgressive sexuality, demagogues, living saints.
\end{abstract}

\section{Introduction: The Heroic Individual and Max Weber's Charisma}

Heroic figures have peopled the western imagination from Homeric and Virgilian epics to the Chanson de Roland and beyond. Thomas Carlyle's celebrated lectures of 1840 were devoted to Heroes, Hero-Worship, and the Heroic in History, which surveyed religious, literary, and political heroes. Carlyle's thesis that "Universal History is at bottom the History of Great Men" has long ceased to be persuasive, although variants of the idea have persisted ([1], pp. 1, 12). One example is Sidney Hook's protagonist in The Hero in History (1943) - the "event-making individual" ([2], p. 229). But does historical significance determine heroic status?

Perhaps the most influential twentieth-century permutation of the idea of the heroic individual was that of the charismatic leader. According to Max Weber (b.1864, d.1920), whose name has become virtually synonymous with charisma, charismatic authority was granted to certain extraordinary individuals whose personal qualities, heroic or saintly, marked them out as unlike other men ([3], pp. 332, 399). Once a charismatic leader has been recognized, his followers were expected to adhere to patterns of behavior or rules of conduct which he laid down ([4], p. 328). ${ }^{2}$

\subsection{Popular "Charisma" and Celebrity Culture}

But if Max Weber knew the fate of the word "charisma," how do we imagine he would respond? Probably not with a wry smile. More likely, he would display the same immensely serious, glacial

Several scholars have helped me revise drafts of my essay; I am their grateful beneficiary: Donald Bloxham, Samuel Cohn, Jr, David d'Avray, Ian Wei, Peter Kaufman. I also wish to thank the colleagues who provided me with references or gave me materials: Judith Green, Rhodri Jeffreys-Jones, Jill Stephenson, Anthony Goodman.

2 The male gender is used because Weber did not seem to envisage females as typical charismatic leaders. 
expression he composed for his photograph - an intellectual's frown surmounting a piercing German professorial stare ([5], frontispiece, pp. 52, 245-49). This could well have been Weber's reaction to the popularization of his key concept. Its extended usage after his death is largely the work of the mass media. A founding father and patron saint of sociology, Weber plucked the word “charisma" from Rudolf Sohm's Christian context, half-secularized it, and granted it right of entry into the academic world ${ }^{3}$ ([5], pp. 52, 246; [6]). But popular culture is no respecter of academic niceties. Whatever it wants, it takes.

Consequently, charismatics are no longer thought of as Weberian inspirational leaders, whether religious or political ([7], p. 732), although calling politicians "charismatic" presents problems of its own ([8], p. 147). ${ }^{4}$ On the contrary, since the 1960s "charisma" has become a label attached to pop musicians, movie stars, sporting heroes, TV personalities, "reality" show victims, glamorous models, and, on occasion, notorious rogues. A whiff of scandal does them no harm, especially if it kindles media interest. Escapees from the common fate-anonymity - these "charismatics" are easily seen as exceptional. Repeated media exposure enhances their marketability, while close-ups foster pseudo-familiarity, even intimacy, between them and their fans. Some date "celebrity culture" to the advent of the movies; others insist that its origins can be traced back to the eighteenth ([9], pp. 9-19) and nineteenth centuries ([10], pp. 95-114; [11] p. 75; [12], chapters 8-9.). Indeed, "celebrity" in its modern sense of being talked about, famous, was applied to individuals by Dr. Johnson, who applied it to himself (1751) ([13], p. 1019).

\subsection{Weberian and Popular "Charisma": Followers and Fans}

Yet there are crucial distinctions as well as parallels between Weberian and popular conceptions of charisma. Unlike Weber's charismatic leaders, today's popular "charismatics" have fans rather than followers, even though fanship occasionally mutates into followership. For instance, when the popular actor Ronald Reagan entered politics, his Holywood fans seemingly metamorphosed into political followers. Reagan won two elections: Governor of California and President of the United States. Then, too, the movie star Arnold Schwarzenegger became Governor of California. Not so long ago, Bob Geldof [14] and Bono (Paul David Hewson) [15] endorsed the televised Live Aid appeal (1985), prompting their myriad fans to follow them, embrace their cause, and create a movement which precipitated an outpouring of generosity.

A good many medieval Christian charismatic leaders installed their disciples in the new religious institutions, monasteries or confraternities, which they had either founded or promoted. Norbert of Xanten, for example, founded the house of Prémontré (1121) as well as the Premonstratensian canons ([16], p. 117). Contemporary Christian televangelists, in what looks like a modern attempt at institution building, try to persuade their viewers to donate funds to exchange fanship for followership by becoming part of the congregation of their new megachurch, or by enrolling in their new faith university. Instances include: Oral Roberts (university); Jerry Falwell

\footnotetext{
Weber always acknowledged a debt to Rudolf Sohm; but whereas Sohm anchored charisma in the New Testament, Weber universalized it.

4 Robert C. Tucker believes that Weber's "very great merit [was] to take this category [charisma] out of the historical world of religion and apply it to political life."
} 
(university); Joel Osteen (megachurch) ([17], p. 2; [18], p. 91ff.; [19], p. 483; [20], p. 122). Here the structural parallels, medieval and modern, seem to reflect a common desire for permanence. Whenever pop stars bathe in the glory of fan clubs, adulation, not moral prescription, holds sway. Notional obligations may be imposed - such as attending pop concerts, purchasing albums, snapping up ghost-written memoirs - all morally unburdensome. Fans crave entertainment; not the seriousness of purpose expected and demanded by the followers of Weberian charismatic leaders.

Nevertheless, the social behavior of fans and followers can approximate each other, particularly in their vociferous ejaculations of collective enthusiasm ([21], I, pp. 26-27). A further similarity is that both Weberian charismatic leaders and popular "charismatics" satisfy a need for community. Whether it is in collectively inbibing the star-quality of the celebrity or participating in the God-given mission of the religious leader, fans and followers can be said to belong to communities of belief. Yet there is an important distinction between the respective communities. Fans belong to "loose-knit or "virtual communities" mediated through the mass media; their relationship with their favorite celebrity is therefore "remote" and of "imagined intimacy." On the other hand, followers can enjoy a "direct, interpersonal" and even "face-to-face" relationship with their charismatic leader ([10], pp. 95-114; [22], pp. 393-97). An unfortunate consequence for fans and followers alike, however, is the risk of manipulation and exploitation.

\subsection{Weber's Concept of Charisma}

Here Max Weber's theory of charisma will be re-examined in comparative perspective, focussing on charismatic religious figures, medieval and modern. Given that Weber, while not ignoring historical particularity, based his broader sociological insights on patterns in comparative history-coherent phenomena in different epochs and regions-such an approach seems appropriate. Weber was attracted to the study of comparative history from an early age. At sixteen he was writing essays such as "Observations on the Ethnic Indo-European Nations" ([23], pp. 46-47). Historical specificity on a broad cross-cultural canvas underpinned Weber's sociological theory.

Nor is it inappropriate to look at Weberian ideas in a medieval setting, for Weber, that most historically-minded of sociologists, had more than a passing acquaintance with the medieval period. His first academic monograph was The History of Commercial Partnerships in the Middle Ages (1889). ([24], pp. 4-5). As H. Stuart Hughes comments, "Weber ['s] whole intellectual life was suffused with historical thinking" ([25], p. 293). Therefore, it seems altogether Weberian to discuss charisma in comparative medieval-modern historical perspective [26]. History and theory will thereby be allowed to rub shoulders, however abrasively.

Weber's charisma is a particular gift, reserved for a special type of leader, but not necessarily a religious leader. Weber argues that a charismatic leader emerges during a time of crisis, dislocation, or disorientation ("a devotion born of distress and enthusiasm"). He gains adherents not because of his noble birth or high office, but by virtue of his extraordinary personal qualities, his "gift of grace" or charisma (which in the Middle Ages was often expressed through his divine mission, the compelling Great Cause which he embodied). Certain characteristic signs - miracles or revelations or prophecies-yield charismatic recognition which is a prerequisite for his followers to pledge complete devotion to their leader. Ultimately, therefore, charisma is a matter of 
perception. It is in the eye of the beholder. Sociologists "must abstain from value judgments" even in cases of apparent fakery.

Possessing the distinctive signs, the nascent charismatic leader, attracts-better, captivates, overwhelms, enthralls - his followers, who recognize his authority, and submit to it. To Weber, Jesus's belief in his own charismatic powers, based on his ability to work miracles, exorcise demons, and preach so effectively, led to his assuming the role of messiah ([29], p. 271; [30], pp. 32-34, 84, 190-96).

One possible outcome of charismatic recognition, therefore, may be a messianic vocation. As with Jesus, too, the charismatic leader's most committed disciples then become the nucleus or core group of his adherents, his Apostles. The charismatic leader next chooses one disciple as his successor, and confers his authority on him. So, it was believed, Jesus chose Peter to govern his church. At this stage, a charismatic community is institutionalized, rationalized, and eventually bureaucratized.

In his critique of pure Weber, Edward Shils comments about attenuated, dispersed forms of charisma pervading institutions ([31], 11, pp. 127-34, 256-75). But there is a danger that by paying overmuch attention to institutionlized charisma and to the ideas and program of the charismatic leader, charisma itself is depersonalized. Without the individual charismatic leader, his ideas are merely ideas. David d'Avray makes the valid point that the acceptance of the leader's ideas and program has much to do with "the intensity" of the leader's "convictions" and, one might add, the strength of their expression ([32], p. 106; [33]). ${ }^{6}$ Self-belief must be communicated to potential followers. Rhetoric, as always, is a powerful tool.

Weber taught that charismatic authority is inherently unstable. It is precarious, depending, as it does, upon continued success. Consequently, it is relatively short-lived ([5], pp. 248-50). One commentator suggests that "the modern sporting hero" exemplifies this, because if he fails time after time, "his following" deserts him ([34], p. 84). But a Weberian leader has followers, not an inchoate following; and, thanks to his charismatic authority, rather than to momentary celebrity, he can lead his followers up or down his chosen path; that is, until his followers choose not to follow him ([35], p. 337). There have been attempts to apply Weber to contemporary situations [36], as well as several attempts to marry Weber and Freud; rarely, in my opinion, a happy marriage ([37]; [38], pp. 5-23; [39], p. 4).

In contradistinction to personal charisma, there is also a Weberian charisma of another sort - charisma of office (Amtscharisma) ([5], pp. 295-99; [35], p. 337). This is the charisma arising from a recognized prestigious status, either traditional or official. In a medieval context, it could be the aura of the throne, whether episcopal, papal or royal, as opposed to the peculiar qualities of the incumbent seated thereon.

\section{4. "Double Charisma”: Bernard of Clairvaux}

Weber appears to disregard what might be called "double charisma" which occurs when charisma of office is coupled with, and reinforces - by helping to legitimize - personal charisma.

\footnotetext{
For this clarification I am indebted to D. L. d'Avray's comments, citing ([27], p. 140). A translation of the relevant passages appears in ([28], I, p. 359).

6 This essay was in draft when d'Avray's books were published.
} 
The fusion is complete when an official status is so absorbed into an individual's persona as to become a personal attribute. The two are then indivisible.

An excellent medieval illustration is Bernard of Clairvaux (1091-1153, can. 1174), the founding abbot of Clairvaux and the leading light of the Cistercian order, the pre-eminent monastic order of its time. When Pope Eugenius III, his former pupil and a fellow Cistercian, summoned the second crusade, Bernard became its foremost official spokesman, both in France and Germany. Preaching the crusade to great crowds in Germany in 1146-47, he reputedly performed many miracle cures, all faithfully recorded by members of his entourage ([40], pp. 54-75, 61, n. 22).

After that crusade's failure, the Council of Chartres (1150), eager to mount a new crusade, chose him, he wrote, "almost as the leader and prince of the army." To choose Bernard, an old, sick monk, as overall commander of a crusading army certainly ran counter to conventional wisdom. The project came to nothing, perhaps owing to Cistercian objections ([41], pp. 311-20, 317). Clearly, what was wanted at Chartres was Bernard's God-given charismatic leadership, not his military prowess. When Bernard preached in Germany, ostensibly to recruit crusaders, he managed to persuade thirty or more would-be crusaders to enter his beloved Cistercian order. Bernard's charismatic authority was as much personal as it was institutional ([42], pp. 22, 35).

Finding a comparable modern instance is problematic. Perhaps a good candidate would be Pope John XXIII (1958-63), the pope of the Second Vatican Council, whose unaffected simplicity and good humor "brought a wind of change to his office" ([43], 320-22).

\section{Charisma as Performance}

\subsection{Medieval Preachers of Popular Crusades}

Charisma is public: it must be made manifest. So how best to manifest it, if not in performance? An unofficial crusade preacher like Peter the Hermit, addressing vast open-air crowds in 1096, and firing hordes of peasants with sufficient enthusiasm to put their lives at risk and follow him on the first crusade, was himself a performer. Barefoot, dressed in the simple, identifiable garb of a hermit, carrying his God-given proof of legitimacy — a celestial letter endorsing the crusade-he was acclaimed a holy man ([44]; [45], pp. 79-107). Hairs were pulled from his mule as relics. He was, reports Guibert of Nogent, endowed with an "amazing authority" (mira auctoritate) ([46], p. 121; [47], pp. 47-48). Although his "amazing authority" was undermined by the losses suffered by his troops and Peter's attempted flight from the crusader encampment at Antioch (1098), the crusade commanders subsequently let him assume a prominent role in the processions and liturgies preceding the crusader victories at Jerusalem and Ascalon (1099) ([48], p. 71). The probable lifespan of Peter's charismatic authority was three years.

For charismatic medieval preachers, appearance mattered, but not personal attractiveness. Rather, it was conformity to a specific type of holy man. Jacob, known as the Master of Hungary, was the most conspicuous preacher of another popular crusade, that of the pastores or Shepherds's Crusade (1251). He was described as having "a large beard, as if he were a man of penitence, with a pale, thin face" and bare feet. The focus of the crowd's attention was held in his clasped hands, displayed but not actually revealed. What it was, he claimed, was a legitimating parchment from the Virgin [49]. Anticlerical riots and attacks on the Jews followed in the wake of the pastores. During 
violent disturbances at Bourges or near it, Jacob was set upon and killed. His charismatic longevity probably lasted no more than four months, from mid-April perhaps to July, 1251 ([49], IX, pp. 2-5).

\subsection{Renaissance Preachers and the Burning of the Vanities}

Medieval preachers used words to establish and consolidate their charisma, but the charismatic performances of some Renaissance preachers were not confined to words. Theatrical flair reinforced their charismatic status as well as winning them followers for moral crusades. Without any doubt the most spectacular event they staged was the burning of the vanities. Heaped up in a conspicuous pile in a town centre, sometimes placed within a specially constructed wooden "castle," were dice, playing cards, wigs, cosmetics, masks, books of love spells, and other such tokens of immorality. The pyre was lit; and up in smoke went individual and communal sinfulness ([50], pp. 62-76).

Counted among the most celebrated Renaissance burners of the vanities was the charismatic Franciscan preacher San Bernardino da Siena (d. 1444), in Florence (1424) and Perugia (1425). He was of emaciated, ascetic appearance and prominently exhibited as a focal point for the auditors of his sermons what became his iconographic attribute - an emblem of the name of Jesus. He also interacted with his audience in ways other than audio-visual. During a sermon against sodomites, he invited his listeners, whenever they encountered one, to spit hard. Everybody did so. The sound, said the scribe, was like thunder ([51], p. 6; [52], p. 150; [53], pp. 154-55). Another Franciscan burner of the vanities was the Beato Bernardino da Feltre ([50], pp. 71-72; [54], pp. 475-78). Strengthened by their charismatic performances, the words of these moral crusaders were drafted into puritanical civic legislation ([55], pp. 265-93). Law was thus made the repository of charisma.

Among modern charismatic preachers were the revivalists of the Great Awakening which swept parts of Great Britain and colonial America in the 1730s and 1740s. The young George Whitefield, having drawn large crowds in Britain, arrived in Philadelphia in 1739 and returned to England in 1741. In common with medieval and modern charismatic preachers, his reputation preceded him. Spiritual rebirth was his aim. The means were: advance publicity; daily open-air preaching; moving from location to location; apparently spontaneous sermons; novelty; a dramatic style. Crowds of unprecedented size were reported ([56], pp. 90-100, 112-16). Similarly, when Dwight Moody and his musical accompanist Ira Sankey brought American evangelical revivalism to major British cities, exciting vast crowds, from 1873 to 1875 , "no revival in modern times has been marked with such immediate and varied results" (to quote a contemporary enthusiast ([57], p. 1). Charismatic preachers, medieval and modern, sought converts, preferably on the spot - to the crusades, moral crusades, or evangelical rebirth. Converts followed Whom their preacher followed.

\section{Professorial Charisma?}

For both medieval and modern preachers, obtaining and ratifying charisma was a performing art. But can charisma of a kind speak from the lectern as well as from the pulpit? Today's "charismatic professors" are a case in point. Among them are popular university lecturers, especially those espousing burning social issues and clever, opinionated, televisual historians. Among the most prominent "charismatic professors" are public intellectuals like the late Edward 
Said and Noam Chomsky, respected academics, unafraid of mobilizing public opinion in support of their political causes. Their intellectual fans can be said to be their followers.

University teachers possess a certain authority, due to their status, which, when coupled with the appropriate personal attributes, manage to sway their students. Weber, on the contrary, would have none of it. In a speech given at the University of Munich in 1918, he addressed his "fellow students," declaring that they were wrong to demand "qualities of leadership" from their teachers. Robustly, Weber declaimed that their scholarly qualities, however excellent, were not the qualities of leaders ([5], p. 150).

Despite Weber's ringing declaration, William Clark attempts to define "professorial charisma" in his Academic Charisma and the Origins of the Research University — and does so by invoking Weber. For Clark, the cult of academic personality stems from a Romantic belief in individual genius plus the insertion of Weberian charisma in a setting of Weberian rational authority ([58], pp. 16, 516, n.21).

According to Clark, before the birth of the modern research university in Protestant Germany (c.1770s-1830s), traditional universities had an aversion to charismatic professors ([58], pp. 3-4, 17). Yet Clark does admit that charismatic masters did lecture at medieval universities, and these were likely to be men who broke the philosophical-theological rules of the game ([58], p. 18). The penalty? The teachings of the Paris magistri Amalric of Bène (d. c.1206) ([59], III, pp. 347-52). and Siger of Brabant (d. c.1284) ([60], p. 249; [61], p. 481) were condemned as heretical. Clark does concede that modern academic charisma did spring from a traditional theme, the compelling spiritual or cultic leadership of a teacher ([58], p. 15). An extreme example is the charismatic Amalric of Bène. His former students, among them parish priests, created a sect, the Amalricians. A few years after their teacher's death, four were imprisoned, and ten were burned at the stake ([59], III, pp. 347-52). The warrior-prince of early scholasticism, Peter Abelard (c.1079-c.1142), was the medieval charismatic teacher, whose skill in disputation brought him fame ([58], p. 75). Accused of heresy in 1140, Abelard was forced to flee from the monastery of St. Denis where he had sought shelter. In his Historia calamitatum, Abelard "found a refuge in the wilderness" where soon "students began to gather... from all parts" ([62], p. 88). There, at his hermitage of the Paraclete, Abelard, the charismatic professor, found followers in a literal sense ([63], pp. 204-5, 238-40, 317-24). 


\section{4. "Collective Charisma"}

\subsection{Medieval}

At first "collective charisma" appears to fly in the face of Weberian individual charistmatic leadership. Yet Weber opens the door for it, when he remarks that "the pneumatic manifestations of charisma among women" are signs of "specifically religious exaltation" ([29], p. 104). Now exaltation was especially manifested during medieval revivals of the laity, male and female, from which individual charismatic leadership sometimes emerged ([64], pp. 147-76). Examples include: Durand of Le Puy, founder of the Caputiati (1182), a peace militia; Stephen of Cloyes, leader of the French Children's Crusade (1212); Nicholas of Cologne, leader of the German Children's Crusade (1212) ([65], pp. 61, 62, 65-77, 102-06); and Jacob, the Master of Hungary, leader of the pastores (1251) ([66], IV, pp. 1093-94). That collective enthusiasm could engender personal charisma was something Weber appreciated.

Conversely, there were occasions of collective fervor when apparently leaderless troops of enthusiasts radiated a charisma which electrified crowds of spectators. The revival of the flagellants (1260-61) began in Perugia, where it was linked with Raniero Fasani. But after the movement dispersed, what mattered was the public spectacle of the flagellants. Spellbound onlookers, transfixed by self-inflicted humiliation, joined the movement and took it to the next town ([67], VIII, pp. 227-67). During the Black Death (1349), troops of flagellants described as "headless" processed through German towns ([68], pp. 3-36, 8, 9, n.15, 16). Then (1374), parts of the Low Countries and the Rhineland witnessed the so-called "dancing mania." These troops of dancers-really leapers-were also, seemingly, acephalic ([69], pp. 339-55; [70], pp. 335-77). The adherence of spectators testifies to the charisma of these "headless" bands of medieval enthusiasts. Most medieval revivals were of short duration, corresponding to the lifespan of their charismatic power. Only relatively few, like the flagellants of 1260 or the Bianchi of 1399, became institutionalized as local confraternities [71]. Nevertheless, these revivals demonstrate the collective charisma of dramatic ritual performances.

\subsection{Modern}

Pentecostalism is their contemporary embodiment, exemplifying Weber's "pneumatic manifestations of charisma." "Classical Pentecostalism" dates back to the Azusa Street revival in Los Angeles (1906). The charismatic renewal movement of the '60s and '70s, swept "Neo-Pentecostalism" into the mainstream Protestant churches, as well as into Catholicism. Its crucial manifestation was glossolalia, a liturgical performance in which individuals or indeed the entire congregation engaged ([72], pp. 405-25; [73], pp. 31-36; [74] XI, pp. 229-35; [75], pp. 428-34). As of 1985, Pentecostalists were counted as the largest single family of American-born sects ([76], p. 139). So, as a religious phenomenon, collective charisma was medieval, just as it is modern. 


\section{Religious Radicals}

\section{1. 'Radicalization from Within' or 'Challenge from Without'?}

Weber sees charismatic domination as no less than a revolutionary force. ([5], p. 250). During the medieval centuries the religious equivalent to revolution was heresy. Some scholars prefer to speak of deviance, schism, and dissent rather than heresy. Certainly from the time of Pope Innocent III's (1198-1216) "counter-attack" the Church perceived heretics as rebels ([77], pp. 99-108). Valdes of Lyon (fl. c. 1176-c. 1205) was the founder of the Waldensian brethren, who, despite Inquisitors and Christian armies, managed to survive ([78], pp. 51, 196). Valdes was a wealthy cloth merchant who renounced his wealth, embraced apostolic poverty, and commenced preaching using vernacular translations of the Gospels. His followers also wanted to preach. The papacy insisted that the local clergy must first grant permission before Valdes and his uneducated followers were allowed to preach. The archbishop of Lyon refused to overturn a clerical monopoly. So the heresy of the Waldensians began as disobedience to clerical authority ([77], pp. 70-85; [78]; [79], pp. 12-14, 17-20, 30-31, 44, 59). The story, told and re-told, of Valdes's dramatic conversion to poverty won him followers. The charisma of Valdes was the charisma of the grand gesture.

As everyone knows, the truly revolutionary break in medieval Christendom occurred at the close of the Middle Ages with Jan Hus and Martin Luther, who, unlike Valdes, were both churchmen. Hence to accommodate medieval charismatic religious leaders who were clerics, a slight refinement to Weber's idea of the charismatic as revolutionary is called for. Put succinctly by Douglas Barnes, citing Peter Berger: "a charismatic leader who occupies an institutional office may attempt to change the religion by a "radicalization from within rather than a challenge from without." ([80], p. 6; [81], pp. 940-50).

Yet with later Protestant sect formation what began as 'radicalization from within' often ended in 'a challenge from without.' Here the U.S. experience is significant. "The sectarian spirit in American Christianity" - with many sects evolving into denominations, then churches - testifies to ongoing disputes over scriptural interpretations, fundamental spiritual values, and personal revelations ([82], pp. 11-24).

\subsection{Medieval Radicals from Within}

In sharp contrast, in the medieval church there were repeated examples of 'radicalization from within' among clerical leaders who were forceful advocates of religious reform, but never hereticated, never mounted 'a challenge from without.' Castigating their less zealous colleagues, they aroused controversy in spite of (or because of) their clerical status. Among the best known of them were the Wanderprediger, the wandering eremitical preachers of northern France from roughly the $1050 \mathrm{~s}$ to the $1120 \mathrm{~s}$. The majority founded new religious communities. Their appearance was distinctive: black cloak, long hair, untrimmed beard, thin-faced, barefoot ([83]; [84], pp. 1-45; [85]). Crowds flocked to hear them preach.

Vitalis of Savigny (d.1122) was an eminent eremitical preacher, monastic founder and reformer. Vitalis "was a man who had studied deeply... and spared neither rich nor poor in his public sermons" ([86], pp. 330-33). He was also a peacemaker. Instead of urging ex-prostitutes to enter 
the cloister, as other preachers would do, Vitalis preferred finding them husbands ([83], pp. 85-88). As outspoken critics of lax monks and clerics, Vitalis, along with other Wanderprediger, was accused of Pharisaism ([87], pp. 14-15). But their route to reform was via the authority of a pre-existing divinely legitimated order. To these men, radical reform implied a return to traditional monastic asceticism, which clashed with the perceived abuses of contemporary monastic life, as reflected in their relatively more comfortable standard of living. This was the temptation presented by the newly reborn urban economy ([88], p. 70).

\section{Charisma: The Economic Dimension}

\subsection{Weber's Idea of the Economics of Charisma}

Max Weber did not ignore the economic implications of charisma. What is unexpected, however, is that Weber constructed his theory of the economics of charisma on medieval foundations. He defines the charismatic economy by what it is not. Using St. Francis as an example, he maintains that the charismatic economy prohibits the use of money ([5], p. 247). It is seemingly paradoxical, but perhaps understandable, that the medieval charismatic rejection of the money economy occurred precisely at the time in which what Lopez called "the commerical revolution of the Middle Ages" took off [89]. Medieval charismatic rejection of the money economy can thus be seen as fundamentally reactionary.

In his stimulating thesis which launched a thousand arguments, The Protestant Ethic and the Spirit of Capitalism (1904-5), Weber invokes the name of the "young St. Francis... [whose] life was modelled directly on that of the Apostles" ([90], pp. 136-37, 146). For Weber, Francis of Assisi (1181-1226; canonized 1228) and the Order of Friars Minor which he founded, epitomized the economy of charisma.

\subsection{The Franciscan Economy of Charisma}

Francis not only espoused poverty, he embodied it. Thomas of Spalato's eye-witness account of Francis preaching before a large crowd in the main square of Bologna in 1222 describes him as "wearing a ragged habit; his whole person seemed insignificant; he did not have an attractive face." Yet "men and women flocked to him," trying to touch him" or "tear off a piece of his poor habit" ([91], pp. 1601-2). But his charisma was recognized well before 1222.

Francis's father Pietro Bernardone was a prosperous cloth merchant; so, like Valdes, Francis reaped the benefits of the money economy. Unlike Valdes, Francis's conversion to poverty was a gradual process (1204?-1208?) ([91], pp. xi-xii). ${ }^{7}$ The best known incident of his conversion was his public repudiation of his father's wealth precisely at the moment when his father was preparing to disinherit him. He stripped naked and handed back his clothes to his father. The officiating bishop of Assisi, Guido, hastily wrapped him in his robe ([91], p. 241; [92], pp. 4-9; [93]). By 1261, the archbishop of Pisa could hail St. Francis of Assisi as not only a wealthy merchant, but also as the patron saint of merchants ([88], pp. 216-17)! Francis thus renounced his father and the

These dates are by no means universally accepted. Alternative dates for Francis's conversion to poverty are suggested in [92], pp. 4-9. 
idea of money simultaneously. When a priest read from the book of Matthew (10: 7-10), in which Jesus instructs the Apostles to go and preach, taking with them neither gold, nor silver, his conversion to Lady Poverty was complete.

Within a couple of years, Francis had eleven companions. To the Franciscans, the charismatic economy meant begging for alms, but never for money. A candidate for the order "should sell all his possessions and give the money to the poor." ([91], pp. 31-32). To cite Malcolm Lambert: "the poverty of Christ was the key idea of the whole Franciscan movement" ([94], p. 59).

Pope Innocent III, after interviewing Francis, ultimately approved his order (1209) ([92], pp. 18-19, 51). What might have appeared to be a group of radical religious dissidents was incorporated within the church. The rapid expansion of the Franciscan order throughout Christendom was phenomenal, but Francis had neither the taste, nor the talent, for managing an ever-expanding religious order. So, in a perfect demonstration of the Weberian theory of charismatic succession, Francis chose his friend Peter Catani as his successor; then he abdicated. The minister-general, closely supervised by the Franciscans's cardinal-protector in Rome, now had control of the order ([92], pp. 50-51, 95-101).

As the order grew rapidly, so did its problems, chief among them the ideal of apostolic poverty, for Franciscanism imposed both individual and collective poverty. Despite the awkward fact that they needed them, Franciscans could own no buildings. Solution: a legal fiction. The church acquired the necessary property. The order had the use of it. Donations from wealthy townspeople, nobles, and kings were put into the building of spacious preaching churches ([88], pp. 164, 203-6).

Poverty continued to be a contentious and divisive issue for the Franciscans, their glory and their burden. The rigorists were uncompromising, but if the order was to serve the needs of the papacy and the church, accommodations were obligatory. Major crises occurred in 1322-23 when Pope John XXII removed any pretence that the Franciscans were not owners of property. He then ruled that the belief of the Spiritual Franciscans in the absolute poverty of Christ was heretical ([95], pp. 275-77). Nevertheless, the heretical Fraticelli, who persevered in the doctrines of the Spirituals, were not violently suppressed until the mid-fifteenth century ([96], pp. 241-72, 585-86).

Increasingly eroded and remote from reality, Francis's pristine vision of the economy of charisma ultimately proved unworkable. Weber would have known the fate of Franciscan economic utopianism, but whether he would have considered what was once Francis's band of brothers "a charismatic community" (Gemeinde) when it had become a religious order, subject to a written constitution (regula), with a defined structure of officialdom is unlikely ([97], vol. 1, p. 243). Monasticism was how the church was able to contain charismatic personalities within a structure governed by canon law.

\subsection{The Weberian Economy of Charisma: Two New Sects}

No such constraints inhibited the charismatic founders of two recent, short-lived Protestant sects: Jim Jones' People's Temple and David Koresh's Branch Davidians. Often termed cults ([98], p. xi, chapters 7-8; [76], pp. 186-87) ${ }^{8}$, both sects would qualify as Weberian charismatic

\footnotetext{
Tabor argues against the demonization of cults [98], while Stark and Bainbridge uphold the distinction between religious sects and cults, particularly in regard to Jim Jones's People's Temple [76].
} 
communities bound together by the emotional tie between the leader and his followers. If so, were their economies economies of charisma?

Jim Jones (1931-78) was the founder and leader of the People's Temple in Indiana, then in San Francisco. Ultimately, he transplanted his followers to a new settlement, Jonestown in Guyana. Of his charismatic leadership, there can be no doubt. On November 18, 1978, he led his Jonestown followers, 913 of them, to their death. Some were murdered, but Jones persuaded the overwhelming majority to commit suicide. He died alongside them ([99], p. 271ff, 288; [100], p. 571). ${ }^{9}$

During his charismatic career, Jones was a faith healer; a spellbinding preacher of thermonuclear apocalypse; a messiah; and a sexual manipulator of both his female and male adherents. He proclaimed himself a living incarnation of Buddha, Jesus, and Lenin. Towards the end he communicated paranoid fears about impending U.S. government intervention ([99], pp. 110-134; [100], pp. 280-81, 94-5; [101], pp. 3-20; [102], pp. 21-34). Jeannie Mills, a defector from Jonestown, recalls: "We surrounded him with this aura of power." ([103], pp. 165-73). Jones demanded and received total control ([104], pp. 174-82). He always presided over meetings, and his will prevailed ([99], pp. 96-98). Jim Jones's version of the Weberian economy of charisma operated, both at the People's Temple in San Francisco and at Jonestown in Guyana. Before there was any hint of socialism, the ideology of the People's Temple was broadcast as apostolic, Christian communalism. In return for donating their income, welfare benefits, and savings, to their church-commune, Jones's followers would have all their needs met ([100], pp. 133, 255; [99], pp. 77-80). After Jonestown perished, the holdings of the People's Temple were estimated at \$11 million ([99], pp. 89-90; [100], p. 324). Although professedly collectivist, Jones's economy of charisma, unlike that of the early Franciscans, by no means spurned the money economy.

After visiting the Holy Land, in 1990, Vernon Howell (1959-1993) became David Koresh ([105], pp. 93, 97). His new name traced his messianic lineage from King David and King Cyrus (Hebrew: Koresh) who freed the Jews from their Babylonian captivity. The home of the Branch Davidians, Koresh's religious community, was Mt. Carmel near Waco. An independent sect, they deviated from, but were theologically anchored in Seventh Day Adventist biblical prophecy ([106], pp. 43-72).

On April 19, 1993, when Mt. Carmel was stormed and burned to the ground, David Koresh, their charismatic leader, died together with most of the Branch Davidians, 74 of them. This was the final act in a controversial siege by the U.S. Bureau of Alcohol, Tobacco, and Firearms (ATF) and the FBI ([107], pp. xiii-xviii). ${ }^{10}$ Whoever bears the ultimate responsibility for the catastrophic fate of the Branch Davidians, the sect's apocalypticism definitely played a part.

For apocalypticism was at the heart of David Koresh's message and his charisma. At first glance two converts, Derek Lovelock, a siege survivor and Alisa Shaw, who later defected, were unimpressed by his appearance (and gave a very similar description) - he was rather short, unshaven, and dressed in jeans, a t-shirt, and a leather jacket. Lovelock later felt he was in the presence of a messenger of God ([108], p. 345; [105], p. 97). The key to Koresh's charisma was his

\footnotetext{
Reiterman's is a thorough, journalistic account based on many interviews with Jonestown defectors [100].

10 Also see Reavis [105], pp. 268-75, who gives the number of the dead as 76, p.13; but his date for Howell's name change, 1989, p. 15, gives rise to doubts.
} 
claim that he alone could unravel the hidden meaning of the Book of Revelation's Seven Seals ([98], pp. 160-63). His God-given ability attracted converts to Mt. Carmel. One affirmed that David, the Messiah, knew what would happen on the Last Days ([106], Paul Fatta, p. 57). And happen it did.

Whether or not the economy of the Branch Davidians qualifies as an economy of charisma is debatable. One writer argues that Mt. Carmel was never a true commune, because all goods were not held in common, although no one paid rent or board ([105], p. 49). But more and more, say scholars, the residents of Mt. Carmel devoted their funds, labor, and zeal to the community ([109], pp. 5-56, 62, 67). In sum, without abandoning the money economy, David Koresh's followers drew nearer to adopting a Weberian economy of charisma.

\section{Charisma and Transgressive Sexuality}

\subsection{Modern Sects: People's Temple and Mt. Carmel}

Ceaseless revelations about the sexual escapades of celebrities flow from the media's obsession with "charisma." To the star-struck, the fame (and fortune?) of the star prove irresistibly attractive. Overlooked, however, is the possible link between Weberian charismatic leaders and sexuality. That such a link does exist is shown by the sexual behavior of our two modern charismatic religious leaders, Jim Jones and David Koresh.

To Jones, having sexual relations with his followers demonstrated his charismatic authority. He is quoted as saying, "As long as I have power... women will always want me." ([103], p. 167). He also let it be known that his sexual appetites - unmarried women as well as the wives of his closest disciples - were not confined to women. Gossip about Jones's sexual prowess added to his charisma ([99], p. 112).

Like Jones's, David Koresh's sexual relationships were a consequence of charisma, but Koresh's liaisons were justified theologically. His followers were instructed that according to the Book of Revelation he and his "spiritual wives" were called upon to procreate a new branch of the House of David ([106], p. 59). Women married to his disciples were not excluded. Jones and Koresh had legal spouses. Jim Jones was a sexual opportunist, while Koresh's transgressed normative sexual boundaries through what might be called charismatic antinomianism. In effect, both men were religious legislators who rewrote society's moral rule book. Weber believes charismatic leaders could do just that ([5], p. 250).

\subsection{Robert of Arbrissel, Medieval Wandering Preacher}

A medieval instance - not so much transgressive, as of provocative sexual behavior-was one of the most celebrated Wanderprediger, Robert of Arbrissel (c.1045-1116). His sympathy for the plight of discarded wives and concubines, and daughters fleeing arranged marriages has preoccupied modern scholars ([110], pp. 175-84). He travelled with a mixed troop of male and female adherents, former prostitutes among them - enthusiasts (or "groupies" in the language of rock-stardom) who first listened to his sermons, then followed him from place to place. Arbrissel settled the most committed of his followers at his monastic foundation, Fontevrault, which became 
the mother house of a number of dependent monasteries. Not long before his death he chose a female successor as abbess over his mixed monastic congregation [111].

After the death of his father, a married parish priest, Robert assumed his role ([112], pp. 1140-60). During his studies at Paris, he came into contact with the ideas of Pope Gregory VII (1073-85), which stressed the separate identities of the clergy and the laity; condemned simony; and fulminated against nicolaitanism. Robert tirelessly advocated Gregorian reforms. Wherever he preached, men and women of all social classes came to hear him. He unashamedly visited brothels, most famously in Rouen, to warm his bare feet, and to preach chastity to the women, who at first mistook him for a client. A number of his fellow clerics clearly disapproved ([112], p. 1152).

His earliest hagiographer, Baudri of Dol, writing c.1118, says that while a student at Angers, Robert took to wearing an iron tunic next to his skin to avoid temptation of the flesh ([113], pp. 10-12). In letter (c.1098) addressed to Arbrissel, but meant to be circulated, Marbode, Bishop of Rennes, rebukes him for his truly scandalous inclination "to love greatly cohabitation with women... in the name of new religious practice." Even if you avoid bodily fornication, he admonishes him, your soul will not remain chaste ([114], pp. 92-100).

Equally censorious, Abbot Geoffrey of Vendôme, similarly circulates a letter to Robert (c.1107.) He has heard that Robert permits certain of his female followers to live with him, and to sleep with him. Attempting to curb his lust, he tortures himself "in a new kind of martyrdom" destined to fail. Such novum et inauditum behavior results in scandal ([115], pp. 103-5; [116], p. 111, n. 68).

However shocking Robert's behavior, it was neither "a new religious practice," nor "a new kind of martyrdom." Known as syneisaktism, subhospitio, subintroductae, and spiritual marriage, it was practised in the early church and in Celtic monasticism. Male and female hermits would live and sleep together without having sexual intercourse. Although Nicaea (325) and other early church councils condemned the practice, those engaging in it believed it would vanquish sexual temptation ([116], pp. 32-33, [85], pp. 26, 68; [117], p. 1319). Denis de Rougement comments that when Tristan and Iseult slept with the drawn sword between them, it merely heightened their desire ([118], p. 49).

Arbrissel's behavior had been deemed provocative during his lifetime. For his "mad audacity" (the judgment of a sympathetic scholar) ([111], p. 239), Robert of Arbrissel paid the penalty, albeit posthumously. The nuns of Fontevrault made two attempts in the seventeenth and nineteenth centuries to have him canonized and both failed. Abbot Geoffrey of Vendôme's letter was cited in evidence against him. Such evidence of provocative behavior helped to put an end to his canonization process, several centuries later ([119], pp. 361-77; [120], IV, pp. 142-43).

\section{Charismatic Politico-Religious Demagogues}

\subsection{Weber, Value-Judgments and Demagogues}

Aware of the problem of value-judgments in the social sciences, Weber holds that, generally speaking, the idea of charisma should remain 'value-neutral' ([5], p. 245; [25], pp. 295, 307-8). It was a difficult balancing act to maintain, especially because Weber extended the idea of charisma from the sociology of religion to political domination ([3], pp. 393-94). With demagogues and demagogy he implicitly takes negative popular usage for granted, and by so doing undermines his 
aspiration for a 'value-neutral' social science. In his lecture "Politics as a Vocation" (1918) Weber makes the bold assertion that however distasteful the term "demagogue" may be, demagogues have typically risen to the leadership of western democracies ever since Pericles became the demagogue of Athens ([5], p. 96).

According to Weber, the democratization of the masses (Massendemokratisierung) and demagogy were part of the same process, ([4], pp. 387-88) Political leaders do not hesitate to employ unscrupulous demagogic means to woo their followers ([121], II, pp. 1094, 1100; [122], III, p. 1449). Weber strongly implies that the successful demagogue would be a charismatic figure, who "could readily become a dictator" ([4], p. 74). Implicitly, demagogy was one outcome of charisma. Not necessarily, however; for Weber characterizes the pre-exilic Hebrew prophets as "world-political demagogues." Yet, because they lacked disciples and community support, could they have been charismatic leaders? ([123], pp. xx-xxi, 275, 279).

\subsection{A Renaissance Politico-Religious Demagogue: Savonarola}

On the other hand, when Weber notes that the Renaissance humanists were unequal to "the demagogy of priests and preachers," he was identifying a charismatic hybrid, at once political and religious, with partisan followers ([29], pp. 133-34). Most likely he was alluding to the Dominican preacher, Girolamo Savonarola (1452-1498), whose demagogic leadership in Florence combined both roles. Weber probably learned about Savonarola from Jacob Burckhardt's classic The Civilization of the Renaissance in Italy (1860). While Burckhardt exaggerates the treasures lost in Savonarola's burning of the vanities (1497), he recognizes his commanding pulpit eloquence ([124], II, pp. 452, 462, 457-58). For Burckhardt, Savonarola was a charismatic demagogue.

Committed to "the myth of Florence," Savonarola gave voice to the providential destiny of his adopted city ([125], pp. 27-66), an outlook he shared with the city's humanists and Neoplatonic philosophers, including Marsilio Ficino, that is, until he renounced him ([126], pp. 80-81, 102-8, 139-44). Shortly before Savonarola's execution, Ficino wrote to the College of Cardinals, vilifying him as a hypocrite who deceived even learned Florentines (like himself?). To Ficino, Savonarola was the Antichrist ([127], pp. 282-83).

Prior of the Observant Dominicans of San Marco, Savonarola began his apocalyptic preaching four years before the invasion of the French King Charles VIII in 1494. No longer a prophet scorned, Savonarola gained much credit, when Charles left Florence unharmed ([125], pp. 137-42). His sermons were now infused with millennial optimism. Florence would become the new Jerusalem. People would repent; and the corrupt Church would be reformed ([128], pp. 183-275). He rose to political prominence, intervening via the pulpit in the constitutional debates of the Signoria ([129], pp. 382-400). He exploited the new medium of the printed word by publishing his sermons in the vernacular ([130], pp. 87-89). His defense of republican liberty polarized Florence ([129], p. 394). Never the ruler of Florence, Savonarola and his followers, the Piagnoni or "the weepers," acted almost like a political party ([130], pp. 77, 83-84, 103-108).

His enemy, Pope Alexander VI, excommunicated him. Florence deserted him. He was tortured and executed on May 23, 1498, hanged, then thrown onto the flames. Nevertheless, the Piagnoni revered his memory for decades. Calls for Savonarola's beatification continue ([126], n.112). 


\subsection{A Modern Politico-Religious Demagogue: Father Coughlin}

Savonarola had medieval predecessors, such as the Dominican John of Vicenza, the celebrated charismatic preacher of the Lombard peace movement of 1233, known as the Great Hallelujah [131]. Of his modern successors, a conspicuous example is the American parish priest Charles Edward Coughlin (1891-1979), who commanded the airwaves during the Great Depression. To Wallace Stegner, Father Coughlin had "a voice made for promises" ([132], pp. 232-57). To his devoted listeners, he was the radio priest. To his biographer, he was the father of hate radio [133].

Coughlin began broadcasting sermons on Christian themes in 1926, soon shifting to politics and economics tinctured with Christian morals, attacking communism and socialism ([134], pp. 150-52). The Wall Street crash was caused by international bankers and "the ideas of 'Karl Marx, a Hebrew." ([133], pp. 34-35). Coughlin's sermons were transmitted on nearly thirty stations. Fortune magazine considered him probably "the biggest thing that ever happened to radio" ([135], p. 119). He founded a political party to oppose FDR, staging a huge political rally in Chicago before the election of 1936. His campaign manager, Philip C. Johnson, said that listening to Coughlin's speech was like listening to Hitler ([133], p. 76). His Union Party collapsed at the polls.

The Nation believed that Father Couglin was a perfect illustration of a demagogue at work ([135], p. 113). He became "a flagrant apologist" and "open admirer" of Franco, Salazar, Mussolini, and Hitler ([136], p. 130). His broadcasts were blatantly antisemitic. He published the Protocals of the Learned Elders of Zion ([133], p. 149). In 1938 he summoned "platoons" of his Christian front, sworn to fight (Jewish) Communism, to bait and attack Jews ([133], pp. 188-89; [134], p. 152). Then came Pearl Harbor. His archbishop ordered him to keep silent or be defrocked. He obeyed. In 1966, he retired as parish priest ([133], p. 269).

Charisma fueled the demagogic authority of Savonarola and Coughlin. Allowing for their different epochs, their careers were comparable. Clerical status (Amtscharisma) lent their politics credibility and legitimacy. Both demagogic careers had a relatively short life span. Coughlin's ascendancy lasted perhaps 8-10 years, Savonarola's about 5. Savonarola was executed. Coughlin's ended his career peacefully, his reputation tarnished. Both men retained their supporters.

Weber knew that communication, whether in performance or by other means, was the key to demagogy ([5], p. 96). Both Savonarola and Coughlin were not only adept pulpit orators, but also utilized new media to diffuse their messages; printing, for one; radio, for the other. Neither held elective office. Both had constituencies swayed by apprehension, expectation, or anger. For Florentines: invasion and conquest. For American workers: unemployment and poverty. Long-held beliefs could be tapped into: Florence's glorious destiny; American populism and antisemitism. Following WWI, Germans wanted a Führer, a hope Weber shared-but for a charismatic leader in the mold of Caesar, not Hitler ([3], pp. 400-4). Weber was spared fascist Europe.

\section{The Charisma of Living Saints}

\subsection{Weber: Living Saints as "Religious Virtuosi"}

When Weber turns to the cult of saints, he limits it to two contexts: personal devotion and the veneration of merchants and craftsmen towards their patron, for veneration was the key to the 
religion of the masses ([29], p. 104). But Weber never associates charisma with dead saints. Living saints are another matter.

Weber terms them "religious virtuosi." According to Weber, popular sanctification was achievable, if demonstrated through religiously inspired ethical conduct. A reputation for sanctity could be gained in much the same way as those possessing "magical charisma" ([2], p. 163). For the medievalist, "magical charisma" presents no difficulty. Medieval saints were obliged to perform miracles, during their lifetime, and/or after their death.

When exceptional individuals in modern, secular society demonstrate religiously inspired ethical conduct, they can also acquire a popular reputation for sanctity. Of these secular living saints who meet the conditions of Weberian charismatic "virtuosi," four are outstanding.

\subsection{Modern Living Saints}

Mahatma Gandhi (1869-1948), a leader in India's struggle for independence, was a Hindu, whose personal asceticism, opposition to untouchability, and espousal of non-violence, gained him followers in the wider world. He was assassinated for his beliefs $[137,138]$. As was Martin Luther King, Jr. (1929-68), a fearless campaigner in the movement for civil rights in the U.S. with many followers in the Southern Christian Leadership Conference. A Baptist minister, King's advocacy of non-violence was inspired by Gandhi ([139], pp. 171-210; [140]). Probably the twentieth-century's most revered secular saint, Nelson Mandela (b.1918), a member of the Wesleyan church, led the African National Congress. Freed from long imprisonment without bitterness and with extraordinary generosity of spirit, he guided South Africa out of apartheid and served as its first black president ([141], pp. 15, 196, 219). The beatified Catholic nun, Mother Teresa (1910-97), founded a religious order, the Missionaries of Charity. Through her singleminded care for the truly wretched in the slums of Calcutta, she was applauded by the world's secular media as epitomizing human compassion ([142], pp. 8, 15, 25).

\subsection{Medieval Living Saints: Catherine of Siena}

Like their modern counterparts, medieval living saints were recognized by their self-defining acts. Fama sanctitatis, a reputation for sanctity, depended upon both virtus moram, conspicuous ethical behavior, and virtus signorum, miracles ([143], pp. 5-8, 17, 30). Stereotypical attributes of sainthood were well-known. The past, however, was not a crushing weight. The typologies of sainthood continued to evolve ([144], pp. 121-69). From the fourteenth to the sixteenth centuries, charismatic female living saints became renowned for their asceticism, miracle-working, and prophetic powers, as well as for acts of personal and civic virtue. Dominican tertiaries were prominent exponents of the "mixed life," active and contemplative. Although they came to live in religious communities, they were not vowed to claustration, which meant they were visible in churches and elsewhere ([145], pp. 2-16, 93).

Their trail-blazer was St. Catherine of Siena (1347-80, can. 1461). She became a Dominican tertiary when she was about sixteen ([146], p. 46). Her hagiographer and confessor was Raymond of Capua, who, after her death, was made Master General of the Dominican Order. He details Catherine's visions, public ecstacies, superhuman fasting, mystical experiences, miracles (e.g., 
receiving Christ's invisible stigmata and his invisible bridal ring), and her spiritual writings ([147], pp. 69-78, 99-101, 164-96). As her ascetic practices and spiritual experiences became public knowledge, so her fama sanctitatis grew. Miraculous cures were atrributed to her. People implored her to spare them from the plague ([145], pp. 19-20, 95, 99-102, 246-48). Unusually for a female religious, she intervened in the affairs of church and state, urging Pope Gregory XI to return from Avignon to Rome, which he did in 1377 ([146], pp. 114-16; [148], pp. 153-200). Strenuously but vainly, she promoted Gregory's crusade as a way of uniting Christendom, converting the Muslims, and removing the condottieri from Christian Europe ([149], pp. 601-22; [150], pp. 120-24) Her fama sanctitatis culminated in her canonization.

\subsection{Medieval Living Saints: Colomba da Rieti}

An "astonishing brood of new Catherines" followed in her footsteps ([143], pp. 1-27). Perhaps the most notable was the Dominican tertiary Beata Colomba da Rieti (1467-1501; beatified 1713), "commonly known as "the second Catherine." A Dominican tertiary at nineteen, she left her parental home, and came to Perugia in 1488 ([145], pp. 252-53; [152], pp. 219-313). The Perugian chronicler Francesco Matarazzo (d.1518) records that "people gave her the name of saint." They "saw her walk openly in the town and speak and hold discourse and reveal secret things." Before long "the rulers of our city built a fair monastery" for her (1490) ([153], pp. 3-4). Between 1490 and 1501, 41 sisters took the habit at Colomba's monastery, St. Catherine of Siena. She was prioress from 1497 to 1500 ([154], pp. 110-59). One year before the plague struck Perugia in 1494, the civic authorities stated that the prayers of saintly Sister Colomba were of the greatest utility to its citizens ([155], pp. 305-6; [156], pp. 132, n.1, 140-43).

The coming of the plague saw the apogee of Colomba's fama as a living saint and protectress of Perugia. She urged the civic authorities to hold processions; and to have a processional plague banner (gonfalone) made ([156], pp. 142-43). They consented. Giannicola di Paolo was commissioned to make the banner (1494). At the foot of the gonfalone, between the towering figures of Saints Dominic and Catherine of Siena, there stood a clearly recognizable Beata Colomba, along with her Dominican sisters, and the townspeople. ([157], pp. 61-74, figure 2a and b). Occupying a central position at the foot of the gonfalone, Colomba's exalted civic and spiritual status was visible to all.

The years of Colomba in Perugia, 1488-1501, correspond to the period of Baglioni dominance in the city ([158], pp. 13-33). The Baglioni were Colomba's loyal supporters ([159], pp. 96, 102-9, 191). So Colomba da Rieti was not simply a "saint of the city... but at the same time a prophetess who put her charisma at the service of political power" ([159], pp. 89-108). The close relationship between the Baglioni and their holy sibyl was obvious to the people of Perugia; equally obvious was her intercession on behalf of her city ([160], pp. 161-75). Modern and medieval, charismatic living saints were Weber's "religious virtuosi".

\section{Concluding Remarks}

In its inflated non-Weberian sense, "charisma" is now so all-encompassing as to be virtually meaningless, except for suggesting a personality cult. Weber's charisma, on the other hand, retains 
its academic utility. In this instance, the juxtaposition of analogous phenomena, medieval and modern, occurring in different circumstances, centuries apart, can be reckoned a test case for Weberian charisma. Allowances made for alterations and discrepancies, Weber's charisma, on the whole, seems to have passed the test.

Hence Weber's ideas can still offer a potentially fruitful perspective, providing they are not treated slavishly. Historical specificity, which Weber valued, must not be lost. Donald Bloxham's note of caution is sensible: "[C]omparative history... is concerned equally with similarities and differences" ([161], p. 319). Weber's sociological perspective lay, for the most part, in similarities. Ignoring differences lends itself to the charge of methodological essentialism, a charge that Weber would have denied ([3], p. 103). He stressed broad patterns, not laws, and pledged his allegiance to historical empiricism. Naturally, Weber was aware that perceptions and varieties of charisma changed over time and across cultures. There is also the paradox of Weber, a sociologist, putting charismatic individuals at the center of his thought ([3], pp. 396-97). One can speculate on influences - the legacy of Romanticism, the Nietzschean übermensch, Stefan George ([3], p. 394). Influence, however, is not the measure of validity.

Finally, there remains the question of the Führer and the demagogue. Sidney Hook's "event-making individual," the ostensible protagonist of The Hero in History, proves to be an anti-hero, a threat to democratic societies ([2], pp. 229-45). Perhaps a survey of the comparative historical impact of various, typologically selected, charismatic leaders would be useful. Secondly, can there be a posthumous charisma? In Heroic Reputations and Exemplary Lives, Geoffrey Cubitt declares that our undertstanding of the idea of the heroic hinges upon reputation, acquired either during a lifetime or posthumously ([162], p. 3). Could the medieval cult of saints and its prerequisite reputation for sanctity, fama sanctitatis, be an illustration? Increasingly, it became a necessary first step in carrying forward the medieval canonization process ([144], pp. 50, 63, 81, 377, 561). To be sure, a culturally maintained reputation, whether bestowed positively or negatively, potentially outlives death. What insures social memory is commemoration-institutional veneration, whether political or religious [163]. What, then, of the abiding memory of Weberian charismatic leadership? Does charisma have an afterlife?

\section{References}

1. Thomas Carlyle. On Heroes, Hero-Worship and the Heroic in History. London: Chapman and Hall, Ltd., 1896, 1, 12.

2. Sidney Hook. The Hero in History. Boston: Beacon Press, 1943, 229-45.

3. Joachim Radkau. Max Weber: A Biography, translated by Patrick Camiller. Cambridge: Polity, 2011, 103, 332, 393-404.

4. Max Weber. The Theory of Social and Economic Organization, translated by A.M. Henderson, and Talcott Parsons. New York: Free Press of Glencoe, 1947, 4, 328, 387-88.

5. Max Weber. From Max Weber: Essays in Sociology, translated and edited by H.H. Gerth, and C. Wright Mills. London: Routledge and Kegan Paul, 1970, frontispiece, 52, 96, 129-56, 245-50, 295-99.

6. Rudolf Sohm. Outlines of Church History, translated by M. Sinclair. London: Macmillan \& Co, 1895. 
7. $\quad$ Robert C. Tucker. "The Theory of Charismatic Leadership." Daedalus 97 (1968): 731-56.

8. Bryan S. Turner. For Weber: Essays on the Sociology of Fate. Boston, London and Henley: Routledge \& Kegan Paul, 1981, 147.

9. Chris Rojek. Celebrity. London: Reaktion, 2001, 9-19.

10. Simon Morgan. "Celebrity: Academic 'Pseudo-event' or Useful Concept for Historians?" Cultural and Social History 8 (2011): 95-114.

11. David Aberbach. Charisma in Politics, Religion and the Media. Houndmills, Basingstoke: Palgrave Macmillan, 1996, 75.

12. John Potts. A History of Charisma. Houndsmills, Basingtoke: Palgrave Macmillan, 2009, chapters 8-9.

13. Clarendon Press. "Celebrity." Oxford English Dictionary, 2nd ed. Oxford: Clarendon Press, 1989, Vol. II, 1019.

14. Bob Geldof. "Look to the Stars: The World of Celebrity Giving." Available online: www.looktothestars.org.celebrity/24 (accessed on 20 August 2012).

15. Bono. "Bono Biography.” @U2,www.atu2.com/band/bono; Live Aid (Google).

16. Henrietta Leyser. Hermits and the New Monasticism. London: Macmillan, 1984, 52, 117, 246.

17. Robert Abelman, and Stewart M. Hoover, eds. Religious Television: Controversies and Conclusions. Norwood: Ablex Publishing Corporation, ca.1990, 2.

18. Hunter James. Smile Pretty and Say Jesus. Athens: University of Georgia Press, 1993, $91 \mathrm{ff}$.

19. James A. Albert. Jim Bakker. Chicago: Open Court, 1998, 483.

20. Mara Einstein. Brands of Faith. London \& New York: Routledge, 2008, 122.

21. Gary Dickson. "Religious Enthusiasm in the Medieval West and the Second Conversion of Europe." In Religious Enthusiasm in the Medieval West: Revivals, Crusades, Saints. Aldershot: Ashgate, 2000, I, 26-27.

22. Aviad Kleinberg. "Are Saints Celebrities?" Cultural and Social History 8 (2011): 393-97.

23. Marianne Weber. Max Weber: A Biography, translated and edited by H. Zohn. New York: John Wiley \& Sons, 1975, 46-47.

24. Gianfranco Poggi. Weber: A Short Introduction. Cambridge: Polity, 2006, 4-5.

25. H. Stuart Hughes. Consciousness and Society: The Reconstruction of European Social Thought, 1890-1930. New York: Vintage Books, 1958, 293-95, 307-8.

26. Guenther Roth. "History and Sociology in the work of Max Weber." British Journal of Sociology 25 (1976): 306-18.

27. Max Weber. Wirtschaft und Gesellschaft, 5th ed. Tübingen: Mohr, 1976, 140.

28. Max Weber. The Theory of Social and Economic Organization, translated by A.M. Henderson, and Parsons, T. New York: Free Press of Glencoe, 1964, I, 359.

29. Max Weber. The Sociology of Religion, translated by Ephraim Fishoff. London: Methuen \& Co., 1966, 104, 133-34, 163, 271.

30. Geza Vermes. The Changing Faces of Jesus. Harmondsworth: Penguin Books, 2002, 32-34, 84, 190-96.

31. Edward Shils. "Charisma" and "Charisma, Order, and Status." In Center and Periphery: Essays in Macrosociology. Chicago: University of Chicago Press, 1975, II, 127-34, 256-75. 
32. D.L. d'Avray. Rationalities in History: A Weberian Essay in Comparison. Cambridge: Cambridge University Press, 2010, 106.

33. D.L. d'Avray. Medieval Religious Rationalities: A Weberian Analysis. Cambridge: Cambridge University Press, 2010.

34. Frank Parkin. Max Weber. Chichester, London \& New York: Routledge, 1982, 84.

35. Joachim Wach. Sociology of Religion. Chicago: University of Chicago Press, 1962, 337.

36. Peter Lassman. "The Rule of Man over Man: Politics, Power and Legitimation." In The Cambridge Companion to Weber, edited by Stephen Turner. Cambridge: Cambridge University Press, 2000, 83-98.

37. Len Oakes. Prophetic Charisma: The Psychology of Revolutionary Religious Personalities. Syracuse: Syracuse University Press, 1997.

38. Charles Camic. "Charisma: Its Varieties, Preconditions, and Consequences." Sociological Inquiry 50 (1980): 5-23.

39. Irvine Schiffer. Charisma: A Psychoanalytic Look at Mass Society. Toronto: University of Toronto Press, 1973, 4.

40. Gary Dickson. "Medieval Christian Crowds and the Origins of Crowd Psychology." Revue d'Histoire Ecclésiastique 95 (2000): 54-75, 61, n.22.

41. Giles Constable. "The Crusading Project of 1150." In Crusaders and Crusading in the Twelfth Century. Farnham: Ashgate, 2008, 311-20, 317.

42. Brian Patrick McGuire. The Difficult Saint: Bernard of Clairvaux and his Tradition. Kalamazoo: Cistercian Publications, 1991, 22, 35.

43. J.N.D. Kelly. The Oxford Dictionary of Popes. Oxford: Oxford University Press, 1988, $320-22$.

44. Jean Flori. Pierre l'ermite et la première croisade. Paris: Fayard, 1999.

45. E.O. Blake, and Colin Morris. "A Hermit Goes to War: Peter and the Origins of the First Crusade." In Monks, Hermits and the Ascetic Tradition. Studies in Church History, 22, edited by W.J. Sheils. Oxford: Blackwell, 1985, 79-107.

46. Guibert of Nogent. Dei Gesta per Francos, edited by R.B.C. Huygens. Corpus Christianorum, Continuatio Medaevalis, 127A. Turnholt, Belg.: Brepols, 1996, 121.

47. August C. Krey, ed. and trans. The First Crusade. Gloucester: Peter Smith, 1958, 47-48.

48. Jonathan Riley-Smith. The First Crusade and the Idea of Crusading. London: The Athlone Press, 1986, 71.

49. Malcolm Barber. "The Crusade of the Shepherds in 1251." In Crusaders and Heretics, 12th-14th Centuries. Variorum Collected Studies Series. Aldershot: Ashgate, 1995, IX, 2-5.

50. Gary Dickson. "Revivalism and Populism in the Franciscan Observance of the Late Quattrocento." In Revival and Resurgence in Christian History, edited by Kate Cooper, and Jeremy Gregory. Studies in Church History, 44. Woodbridge: Boydell \& Brewer, 2008, $62-76$.

51. Katherine L. Jansen, and Miri Rubin, eds. Charisma and Religious Authority: Jewish, Christian, and Muslim Preaching, 1200-1500. Turnhout: Brepols, 2010, 6.

52. Franco Mormando. Bernardino of Siena and the Social Underworld of Early Renaissance Italy. Chicago and London: University of Chicago Press, 1999, 150. 
53. William Heywood. Palio and Ponte. London: Methuen, 1913, 154-55.

54. Richard Trexler. Public Life in Renaissance Florence. New York and London: Academic Press, 1980, 475-78.

55. Gary Dickson. "Encounters in Medieval Revivalism: Monks, Friars, and Popular Enthusiasts." Church History 68 (1999): 265-93.

56. Frank Lambert. Inventing the "Great Awakening”. Princeton: Princeton University Press, 1999, 90-100, 112-16.

57. Rufus W. Clark. The Work of God in Great Britain. London: Sampson Low, 1875, 1.

58. William Clark. Academic Charisma and the Origins of the Research University. Chicago and London: University of Chicago Press, 2006, 3-4, 15-18, 75, 516, n.21.

59. Gary Dickson. "The Burning of the Amalricians." In Religious Enthusiasm in the Medieval West: Revivals, Crusades, Saints. Aldershot: Ashgate, 2000, III, 347-52.

60. David Knowles. The Evolution of Medieval Thought, 2nd ed. London \& New York: Longman, 1988, 249.

61. John H. Mundy. Europe in the High Middle Ages, 1150-1309. London: Longman, 1973, 481.

62. Abelard. The Letters of Abelard and Heloise, translated by Betty Radice. Hammondsworth: Penguin, 1974, 88.

63. M.T. Clanchy. Abelard: A Medieval Life. Oxford: Blackwell, 1997, 204-5, 238-40, 317-24.

64. Gary Dickson. "Medieval Revivalism." In Medieval Christianity, edited by Daniel E. Bornstein. A People's History of Christianity, 4, general edited by Denis R. Janz. Minneapolis: Fortress Press, 2009, 147-76.

65. Gary Dickson. The Children's Crusade: Medieval History; Modern Mythistory. Basingstoke \& New York: Palgrave-Macmillan, 2008, 61-62, 65-77, 102-06.

66. Gary Dickson. "Shepherds' Crusade, First (1251)." In The Crusades: An Encyclopedia, edited by Alan Murray. Santa Barbara: ABC Clio, 2006, IV, 1093-94.

67. Gary Dickson. "The Flagellants of 1260 and the Crusades." In Religious Enthusiasm in the Medieval West: Revivals, Crusades, Saints. Aldershot: Ashgate, 2000, VIII, 227-67.

68. Samuel K. Cohn, Jr. "The Black Death and the Burning of the Jews." Past \& Present 196 (2007): 3-36, 8-9, n.15-16.

69. Madeleine Braekman. "La dansomanie de 1374: hérésie ou maladie?" Revue du Nord 63 (1981): 339-55.

70. Markus Müller. "Eine Trierer Bistumschronik aus der Zeit des Grossen Schismas." Archiv für Mittelrheinische Kirchengeschichte 49 (1997): 335-77.

71. Daniel E. Bornstein. The Bianchi of 1399; Popular Devotion in Late Medieval Italy. Ithaca: Cornell University Press, 1993.

72. Joe Creech. "Visions of Glory: The Place of the Azusa Street Revival in Pentecostal History." Church History 65 (1996): 405-25.

73. C.M. Robeck, Jr. “Azusa Street Revival.” In Dictionary of Charismatic Movements, edited by Stanley M. Burgess, et al. Grand Rapids: Zandervan Publishing, 1988, 31-36.

74. Robert M. Anderson. "Pentecostal and Charismatic Christianity." In The Encyclopedia of Religion. New York: Macmillan, 1987, XI, 229-35. 
75. Andrew Walker. "Pentecostalism and Charismatic Christianity." In The Blackwwell Encyclopedia of Modern Christian Thought, edited by Alister E. McGrath. Oxford: Basil Blackwell, 1993, 428-34.

76. Rodney Stark, and William S. Bainbridge. The Future of Religion: Secularization, Revival, and Cult Formation. Berkeley: University of California Press, 1985, 139, $186-87$.

77. Malcolm Lambert. Medieval Heresy, 3rd ed. Oxford: Blackwell, 2002, 70-85, 99-108.

78. Peter Biller. The Waldenses, 1170-1530: Between a Religious Order and a Church. Aldershot: Ashgate, 2001, 12, 14, 17, 20, 30-31, 44, 51, 59, 196.

79. Euan Cameron. Waldenses: Rejections of the Holy Church in Medieval Europe. Oxford: Blackwell, 2000, 12-14, 17-20, 30-31, 44, 59.

80. Douglas F. Barnes. "Charisma and Religious Leadership: An Historical Analysis." Journal for the Scientific Study of Religion 17 (1978): 1-17.

81. Peter Berger. "Charisma and Religious Innovation: The Social Location of Israelite Prophecy." American Sociological Review 28 (1963): 940-50.

82. Elmer T. Clark. The Small Sects in America. rev. ed. Gloucester: Peter Smith, 1981, 11-24.

83. Johannes von Walter. Die ersten Wanderprediger Frankreichs, 1-2. Leipzig: Georg Böhme, 1903-1906, 85-88.

84. Louis M. Raison, and René Niderst "Le mouvement érémitique dans l'ouest de la France à la fin du $\mathrm{xi}^{\mathrm{ie}}$ siècle et au début du xii ${ }^{\mathrm{ie}}$." Annales de Bretagne 55 (1948): 1-45.

85. Giles Constable. The Reformation of the Twelfth Century. Cambridge: Cambridge University Press, 1996.

86. Marjorie Chibnall, ed. and trans. The Ecclesiastical History of Orderic Vitalis. Oxford: Oxford University Press, 1973, IV, 330-33.

87. Giles Constable, and B. Smith, eds. and trans. Libellus de Diversis Ordinibus et Professionibus qui Sunt in Aecclesia. Oxford: Clarendon Presss, 1972, 14-15.

88 Lester K. Little. Religious Poverty and the Profit Economy in Medieval Europe. London: Elek, 1978, 70, 122-27, 164, 203-6, 216-17.

89. Robert S. Lopez. The Commerical Revolution of the Middle Ages. Englewood Cliffs: Prentice-Hall, 1971.

90. Max Weber. The Protestant Ethic and the Spirit of Capitalism, translated by Talcott Parsons. New York: Charles Scribner's Sons, 1958, 136-37, 146.

91. Marion A. Habig, ed. St. Francis of Assisi: Early Writings and Early Biographies, 3rd rev. ed. London: Society for Promoting Christian Knowledge, 1973, xi-xii, 31-32, 241, 1601-2. Permission to publish by the copyright holder, SPCK, is gratefully acknowledged.

92. John Moorman. A History of the Franciscan Order from its Origins to the Year 1515. Chicago: Franciscan Herald Press, 1988, 4-9, 18-19, 50-51, 95-101.

93. Richard C. Trexler. Naked before the Father: The Renunciation of Francis of Assisi. New York: Peter Lang, 1989.

94. Malcolm Lambert. Franciscan Poverty. The Doctrine of the Absolute Poverty of Christ and the Apostles in the Franciscan Order, 1210-1323. London: Society for Promoting Christian Knowledge, 1961, 59. Permission to publish by the copyright holder, SPCK, is gratefully acknowledged. 
95. David Burr. The Spiritual Franciscans. University Park: Pennsylvania State University Press, 2001, 275-77.

96. Duncan Nimmo. Reform and Division in the Franciscan Order, 1226-1538. Rome: Capuchin Historical Institute, 1987, pp. 241-72, 585-86.

97. Max Weber. Economy and Society, edited by Guenther Roth, and C. Wittich. New York: Bedminster Press, 1968, I, 243.

98. James D. Tabor, and Eugene V. Gallagher. Why Waco? Cults and the Battle for Religious Freedom in America. Berkeley: University of California Press, 1995, p. xi; caps. 7-8.

99. John R. Hall. Gone from the Promised Land: Jonestown in American Cultural History. New Brunswick and London: Transaction Books, 1987, 77-80, 89-90, 96-98, 110-134, 271-288.

100. Tim Reiterman. Raven: The Untold Story of the Rev. Jim Jones and his People. New York: Dutton, 1982, 94-5, 133, 255, 280-81, 324, 571.

101. Ken Levi. "Jonestown and Religious Commitment in the 1970s." In Violence and Religious Commitment: Implications of Jim Jones' People's Temple Movement. University Park: Pennsylvania State University Press, 1982, 3-20.

102. James T. Richardson. "A Comparison between Jonestown and Other Cults." In Levi, 21-34.

103. Jeannie Mills. "Jonestown Masada." In Levi, 165-73, 167-169. Permission to publish by the copyright holder, Pennsylvania State University Press, is gratefully acknowledged.

104. Ken Levi. “Conclusion: Religion and Violence.” In Levi, 174-82.

105. Dick J. Reavis. The Ashes of Waco: An Investigation. New York, London: Simon and Schuster, 1995, 49, 93, 97.

106. David G. Bromley, and Edward D. Silver. "The Davidian Tradition from Patronal Clan to Prophetic Movement." In Armageddon in Waco: Critical Perspectives on the Branch Davidian Conflict, edited by Stuart A. Wright. Chicago: University of Chicago Press, 1995, 43-72, 57-59, 65.

107. Stuart A. Wright. "Introduction.” In Wright, xiii-xviii.

108. Derek Lovelock cited in Kenneth G. C. Newport. The Branch Davidians of Waco: The History and Beliefs of an Apocalyptic Sect. Oxford: Oxford University Press, 2006, 345, and Alisa Shaw [105], 97.

109. Bromley and Silver. "The Davidian Tradition.” In Wright, 5-56, 62, 67.

110. Jacqueline Smith. "Robert of Arbrissel: Procurator Mulierum" In Medieval Women. Studies in Church History, Subsidia, 1, edited by Derek Baker. Oxford: Blackwell, 1978, 175-84.

111. Jacques Dalarun. L'impossible sainteté: la vie retrouvée de Robert d'Arbrissel. Paris: Cerf, 1985, 239.

112. Jacques Dalarun. "Robert d'Arbrissel et les Femmes." Annales E.S.C. 39 (1984): 1140-1160.

113. Baudri of Dol. "First Life of Robert of Arbrissel." In Robert of Arbrissel: Medieval Religious Life, translated and edited by Bruce L. Venarde. Washington: Catholic University of America Press, 2003, 6-21. Permission to publish by the copyright holder, Catholic University of America Press, is gratefully acknowledged.

114. Marbode of Rennes. "Letter to Robert of Arbrissel." In Robert of Arbrissel: Medieval Religious Life, translated and edited by Bruce L. Venarde. Washington: Catholic University of America Press, 2003, 92-100. 
115. Geoffrey of Vendôme. "Letter to Robert of Arbrissel." In Robert of Arbrissel: Medieval Religious Life, translated and edited by Bruce L. Venarde. Washington: Catholic University of America Press, 2003, 101-05.

116. Dyan Elliot. Spiritual Marriage: Sexual Abstinence in Medieval Wedlock. Princeton: Princeton University Press, 1993, 111, n.68, 32-33.

117. "Subintroductae." In Oxford Dictionary of the Christian Church, 2nd ed. rev., edited by F.L. Cross, and E.A. Livingstone. New York: Oxford University Press, 1990, 1319.

118. M. Belgion, trans. Love in the Western World. New York: Doubleday, 1957, 49.

119. J.M.B. Porter. "Fontevrault Looks Back to her Founder: Reform and the Attempt to Canonize Robert of Arbrissel" In The Church Retrospective. Studies in Church History, 33, edited by R.N. Swanson. Woodbridge: Boydell Press, 1997, 361-77.

120. Prospero Lambertini (later Pope Benedict XIV). De servorum Dei beatificatione e beatorum canonizatione, 2nd ed. Rome: Typographi Vaticani, 1788, IV, 142-43.

121. Max Weber. Wirtschaft und Gesellschaft, edited by Johannes Winckelmann. Cologne/Berlin: Kiepenheuer \& Witsch, 1964, II, 1094, 1100.

122. Max Weber. Economy and Society, edited by Guenther Roth, and C. Wittich. New York: Bedminster Press, 1968, I, 243.III, 1449.

123. Max Weber. Ancient Judaism, translated and edited by Hans H. Gerth, and Don Martindale. London: George Allen and Unwin, 1952, xx-xxi, 275, 279.

124. Jacob Burckhardt. The Civilization of the Renaissance in Italy, translated by S.G.C. Middlemore. New York: Harper and Bros, 1958, II, 452, 462, 457-58.

125. Donald Weinstein. Savonarola and Florence: Prophecy and Patriotism in the Renaissance. Princeton: Princeton University Press, 1970, 27-66, 35, 137-42.

126. Lorenzo Polizzotto. The Elect Nation: The Savonarolan Movement in Florence, 1494-1545. Oxford: Clarendon Press, 1994, 80-81, 102-8, 139-44, n.112.

127. Bernard McGinn. Visions of the End: Apocalyptic Traditions in the Middle Ages. New York: Columbia University Press, 1979, 282-83.

128. Bernard McGinn, ed. and trans. Apocalyptic Spirituality. Classics of Western Spirituality. London: SPCK, 1980, 183-275.

129. John M. Najemy. A History of Florence, 1200-1575. Malden: Blackwell Publishing, 2006, $382-400$.

130. Lauro Martines. Scourge and Fire: Savonarola and Renaissance Florence. London: Jonathan Cape, 2006, 77, 83-89, 103-108.

131. Augustine Thompson, O.P. Revival Preachers and Politics in Thirteenth-Century Italy: The Great Devotion of 1233. Oxford: Oxford University Press, 1992.

132. Wallace Stegner. "The Radio Priest and his Flock" In The Aspirin Age, edited by Isabel Leighton. London, Bodley Head, 1950, 232-57, 234.

133. Donald Warren. Radio Priest: Charles Coughlin, the Father of Hate Radio. New York: The Free Press, 1996, 34-35, 76, 149, 188-89, 269.

134. Francis R. McBride. "Coughlin, Charles Edward." Dictionary of American Biography. Supplement 10. New York: Scribner, 1995, 150-52. 
135. Alan Brinkley. Voices of Protest: Huey Long, Father Coughlin and the Great Depression. New York: Vintage Books, 1983, 113, 119.

136. Michael Kazin. The Populist Persuasion: An American History. New York: Basic Books, 1995, 130.

137. Margaret Chatterjee. Gandhi and the Challenge of Religious Diversity. New Delhi: Promilla and Co, 2005.

138. Ignatius Jesudasan, S.J. A Gandhian Theology of Liberation. Maryknoll: Orbis Books, 1984.

139. Janine A. Sawada. "Interpretations of Martin Luther King, Jr.: A Bibliographical Essay.” In The Ethics of Martin Luther King, Jr. by Ervin Smith. Studies in American Religion, 2. New York \& Toronto: Edwin Mellen Press, 1981, 171-210.

140. Kenneth Slack. Martin Luther King. London: SCM Press, 1970.

141. Nelson Mandela. Long Walk to Freedom the Autobiography of Nelson Mandela. London: ABACUS, 1995, 15, 196, 219.

142. Gëzim Alpion. Mother Teresa: Saint or Celebrity? London and New York: Routledge, 2007, $8,15,25$.

143. Aviad M. Kleinberg. Prophets in their own Country: Living Saints and the Making of Sainthood in the Later Middle Ages. Chicago and London: University of Chicago Press, 1992, 5-8, 17, 30.

144. André Vauchez. La Sainteté en Occident aux derniers siécles du Moyen Age. rev. ed. Rome: École Française de Rome, 1988, 50, 63, 81, 121-69, 377, 561.

145. Maiju Lehmijoki-Gardner, ed. Dominican Penitent Women. New York and Mahwah: Paulist Press, 2005, 2-20, 93-102, 246-8, 252-53.

146. Maiju Lehmijoki-Gardner. Worldly Saints: Social Interaction of Dominican Penitent Women in Italy, 1200-1500. Helsinki: Suomen Historiallinen Seura, 1999, 46, 114-16.

147. Raymond of Capua. The Life of St. Catherine of Siena, translated by George Lamb. London: Harvill Press, 1960, 69-78, 99-101, 164-96.

148. Edmund G. Gardner. Saint Catherine of Siena. London: J.M. Dent and Co., 1907, 153-200.

149. Suzanne Noffke. "Catherine of Siena." In Medieval Holy Women in the Christian Tradition, c.1100-c.1500, edited by Alastair Minnis and Rosalynn Voaden. Turnhout: Brepols, 2010, 601-22.

150. Paul Rousset. Histoire d'une Idéologie: la Croisade. Lausanne, Switz.: Editions l'Age d'Homme, 1983, 120-24.

151. Daniel Bornstein. "Women and Religion in Late Medieval Italy: History and Historiography." In Women and Religion in Medieval and Renaissance Italy, edited by Daniel Bornstein, and Roberto Rusconi, translated by Margery J. Schneider. Chicago \& London: University of Chicago Press, 1996, 1-27.

152. Gabriella Zarri. "Living Saints: A Typology of Female Sanctity in the Early Sixteenth Century." In Women and Religion, edited by Bornstein and Rusconi. Chicago \& London: University of Chicago Press, 1996, 219-313, 225-26.

153. Francesco Matarazzo. Chronicles of the City of Perugia, 1492-1503, translated by Edward Strachan Morgan. London: J.M. Dent and Co., 1905, 3-4. 
154. Giovanna Casagrande. "Terziarie domenicane a Perugia." In Una Santa, Una Città, edited by Giovanna Casagrande, and Enrico Menestò. Spoleto: Centro Italiano di Studi sull'Alto Medioevo, 1991, 110-59.

155. William Heywood. A History of Perugia, R. Langston Douglas, ed. London: Methuen and Co., 1910, pp. 305-6.

156. Annali Decemvirali, an.1491-92, f.63r, an.1493, flv., f.48r, f.63v. In Storia della B. Colomba da Rieti, edited by Ettore Ricci. Perugia: Tipografia V. Santucci, 1901, 132, n.1., 140-43.

157. Francesco Federico Mancini. “Arte e Società nella Perugia dei Baglioni." In Una Santa, Una Città, by Casagrande and Menestò. Spoleto: Centro Italiano di Studi sull'Alto Medioevo, 1991, 61-74, figures. 2a, 2b.

158. Rita Chiacchella, and Maria Grazia Nico Ottaviani. "Perugia tra Quattrocento e Cinquecento: un difficile equilibrio." In Una Santa, Una Città, by Casagrande and Menestò. Spoleto: Centro Italiano di Studi sull'Alto Medioevo, 1991, 13-33.

159. Gabriella Zarri. "Colomba da Rieti e i movementi religiosi femminili del suo tempo." In Una Santa, Una Città, by Casagrande and Menestò. Spoleto: Centro Italiano di Studi sull'Alto Medioevo, 1991, pp. 89-109, 191.

160. Enrico Menestò. "La legenda della beata Colomba e il suo biografo." In Una Santa, Una Città, by Casagrande and Menestò. Spoleto: Centro Italiano di Studi sull'Alto Medioevo, 1991, pp. 161-75.

161. Donald Bloxham. The Final Solution: A Genocide. Oxford: Oxford University Press, 2009, 319. Cited by permission of Oxford University Press.

162. Geoffrey Cubitt, and Allen Warren, eds. Heroic Reputations and Exemplary Lives. Manchester \& New York: Manchester University Press, $2000,3$.

163. James Fenton, and Chris Wickham. Social Memory. Oxford: Blackwell, 1992. 
Reprinted from Religions. Cite as: Kaufman, P.I. "Augustine on Manichaeism and Charisma." Religions 3 (2012): 808-816.

\title{
Augustine on Manichaeism and Charisma
}

\section{Peter Iver Kaufman}

\begin{abstract}
Augustine was suspicious of charismatics' claims to superior righteousness, which supposedly authorized them to relay truths about creation and redemption. What follows finds the origins of that suspicion in his disenchantment with celebrities on whom Manichees relied, specialists whose impeccable behavior and intellectual virtuosity were taken as signs that they possessed insight into the meaning of Christianity's sacred texts. Augustine's struggles for self-identity and with his faith's intelligibility during the late 370s, 380s, and early 390s led him to prefer that his intermediaries between God and humanity be dead (martyred), rather than alive and charismatic.
\end{abstract}

The Manichaean elite or elect adored publicity. Augustine wrote the first of his caustic treatises against them in 387, soon after he had been baptized in Milan and as he was planning passage back to Africa, where he was born, raised, and educated. Baptism marked his devotion to the emerging mainstream Christian orthodoxy and his disenchantment with the Manichees' increasingly marginalized Christian sect, in which, for nine or ten years, in North Africa and Italy, he listened to specialists - charismatic leaders and teachers. Subsequently he suggested, with regret, that he had believed as they did and had encouraged his friends to respond similarly ([1], 2.19.68; [2], 3.6.11). ${ }^{1}$ He accepted the claims that, as a breed set apart, the elect possessed the power to liberate the Light trapped in creation and that what they knew of divinity elevated humanity, in large part, because temptations of the flesh that assailed ordinary others were mere nuisances to them ([2], 3.10.18). But by the time Augustine was baptized, he had ceased trying to convince friends of the Manichaean charismatics' impeccable character and enviable knowledge. Unlike the leadership of mainstream Christianity, who preached humility and shunned celebrity (non amant propatula), the Manichaean charismatics relished the latter, according to Augustine, who was determined to make them notorious for arrogance and immorality ([3], 2.4).

\footnotetext{
1 Citations in the text give the book, section, and/or chapter numbers used in editions of Augustine's work, the most accessible of which is on-line at http://www.augustinus.it/latino/index.htm, drawn from volumes 32 to 45 , Patrologia cursus completes, ser. Latina, edited by Jacques Paul Migne and published in Paris from 1844 to 1864. To translate, I have consulted variations cited in relevant volumes of the Corpus Scriptorum Ecclesiasticorum Latinorum and the Corpus Christianorum, series latina. The titles of Augustine's work appear in the reference section, numbered in the order cited.
} 
To do so, he relied on rumor as well as on his own experiences of the specialists' hypocrisy. He said that he had never met one of the elect who was above suspicion of scandal. Most of them, he went on, were petulant; they were a constantly quarrelsome lot, uncivil to their colleagues and condescending to their followers (or "auditors"). Manichaean charismatics were especially contemptuous of critics and seldom disciplined their peers ([1], 2.16.51). On the rare occasion when the outrageous behavior of one of their number was acknowledged, the culpable character could be heard appealing — with success - to the sect's founder, Mani, who supposedly intimated that "its first hero," Adam, was known to have sinned egregiously yet was soon after and long after regarded as righteous ([1], 2.19.72).

Augustine concluded his initial anti-Manichaean screed with the story of an affluent devotee in Rome who tried to rehabilitate the reputation of his sect's elite for holiness. He was not one of the elect but offered them hospitality. They could live comfortably on his estate, if only they conformed to standards of behavior that Mani commended. Augustine implied that their host's generosity would have made a massive difference, if the beneficiaries would have cooperated, yet they did not, and the venture failed. The elect's dedication to the founder was insufficiently influential to attenuate the specialists' dislike-Augustine said "hatred" —of each other. And they lost no love on their auditors, who-much as their host—seemed eager to wait upon them ([1], 2.20.74). Manichees who picked and prepared fruits and vegetables for the charismatics' meals were not permitted to dine with them, because the elite's eating was its "most sacred" task"; the sect's specialists were "the real saviors," J. Kevin Coyle, explains, saviors, whose mastication and digestion mysteriously released Light from its material prison ([4], p. 310). At his most sarcastic, Augustine imagined gluttonous, self-important charismatics belching sacred Light into heaven after a sumptuous feast, having eaten to excess and having left no morsel for followers ([1], 2.16.52 and 2.17.57; [5], 5.10; [6], p. 308).

What the charismatic few lavished on followers, Augustine included, were "extravagant promises" ([1], 2.17.55). The elite, that is, promised to supply truths about the cosmos as well as rationally defensible interpretations of Christianity, which, when he turned critic, Augustine took to be "diabolical" distractions. "They kept saying 'truth, truth,' and told me that they had much to reveal, yet there was no truth in them" ([3], 3.6.10). He trusted the sect's teachers, but later, reflecting on his years listening to their promises and explanations, he scolded himself for not having realized that they were "utterly confused" ([3], 14.31). Manichees had persuaded him that no good could come from pursuing truth among the many Christians in congregations that honored no charismatic truth seer or sayer, other than Jesus and his deceased disciples; a sect's elite, however, could satisfy an earnest seeker who wanted a religion that cultured Christians would not despise ([3], 7.17; [7], pp. 219-21).

"I fell in with the Manichees (in tales homines incidisse)," because their teachers promised to make Christianity intelligible. They promised not to resort to superstitions that overawed the unsophisticated among the faithful, and they would not intimidate smaller fry. They vowed to set aside their "frightfully exalted authority" and appeal to reason, "pure and simple" (mera et simplici ratione). "Who would not be seduced by such promises" (quis non pollicitationibus illiceretur)? Augustine, then an adolescent "eager to learn the truth" (cupidus veri) and impatient with having been asked or ordered to accept what seemed to be scriptural fictions associated with his mother's 
more mainstream Christianity, was drawn to the cultic discourses common in Manichaean circles $([3], 1.2) .^{2}$

Then, in 383, he acquired a new student. An acclaimed Manichaean adept, Faustus, came to Carthage to study classical literature, hoping to learn from Augustine, a lesser Manichee, how to market Manichaeism to cultivated Christians. His new teacher, however, was hoping to learn from Faustus how to make sense of their sect's doctrines. Augustine probed. His pupil resisted ([2], 5.7.12). Augustine's reports of their discussions harp on Faustus's evasiveness and on the sect's unfulfilled promises. They do not complain that his distinguished Manichaean student had explicitly promised anything. Rather, Faustus's reputation preceded him and led Augustine and other local Manichees to expect that their guest would answer all their questions, quasi de caelo, as if he were a celestial oracle ([3], 8.20). François Decret conjectures that Faustus's coming stirred "messianic expectations" ([6], pp. 58-59). Be that as it may, Augustine would almost certainly have thought of Faustus when he groused that Mani, the sect's founder, and other Manichaean charismatics were always promising yet never delivering the truth ([10], 11.12). ${ }^{3}$

They mocked the faith of ordinary Christians and promised to replace it with a religion based on a sturdier foundation, on what Mani described as "comprehensive solid science" ([10], 13.17). From Augustine's perspective, neither Mani nor Manichaean luminaries who succeeded him supplied anything of the sort. Their promises were seductive and attracted Christians to the Manichees' eccentricities ([12], pp. 244-47; [13], p. 93; [14], pp. 7-9), but Faustus proved to be of no particular importance to Augustine, save, subsequently, as a foil, when he attributed to Faustus's behavior his own disillusionment: "Oblivious to his effect on me" (nec volens nec sciens), Faustus "eroded my enthusiasm for Manichaeism" ([2], 5.7.13).

Neoplatonism had all but replaced Manichaeism as the interpretive key to Augustine's Christianity by the time he wrote about Faustus's far less than hypnotic effects on Carthaginian Manichees. Nearly fifteen years had passed ([15], p. 44; [16], p. 127). His reflections, no doubt, were affected by what Faustus failed to clarify (and by Manichaean charismatics' misbehavior), yet historian Peter Brown is probably correct to assume that the Manichees' "intense and highly spiritualized relationships" continued to be prized by Augustine. "The mood" of Manichaean cells, their bonds of spiritual friendship, captivated him after the leadership did not — and until something somewhat similar replaced them-specifically, the company of Christian ascetics, who cherished the leisure (otium divinum) to explore what sacred texts and philosophy contributed to their

\footnotetext{
2 I borrow the phrase "cultic discourse" from Jason BeDuhn, who intriguingly suggests that the "vividness" of Augustine's recollections of his adolescent quest for truth may be due to "his close scrutiny of his child's behavior," attention that "most likely reflects an active interest at the time in what it might indicate about human nature" in light of the Manichaean specialists' "teachings" on that topic [8], p. 322, n. 58. Johannes van Oort gathers from the vivid recollections that Augustine found "the Christ-centered character of Manichaeism" irresistible [9], pp. 508-9.

3 Faustus's apparent caution was unusual, if we may trust Augustine, who berated the sect's other accomplished polemicists who were more combative and forthcoming with criticisms of current wisdom ([3], 6.13). Nonetheless, contemporary studies of charismatic leadership contend that "the most challenging and critical period" for leaders attempting to reorient followers "calls for a high level of negation [which] serve[s] the rhetorical function ... of unfreezing ... attitudes and values" [11], pp. 472-76).
} 
comprehension of creation and who made no extravagant claims to knowledge. ([17], pp. 485-86; [4], pp. 244-48).

What apparently bound Augustine and his like-minded friends together, during their first "retreat" to a country estate near Milan in 386 and, afterward, to his country home in Africa, was their determination to study scripture and what historian Carol Harrison characterizes as a "sense of unworthiness" that clearly distinguished their teacher and leader of their enterprise, Augustine, from the charismatic Manichean elites ([18], p. 31). That distinction, however, did not prevent one early fifth-century critic from complaining that Augustine had organized a new Manichaean cell. He denied it ([19], 3.40.48; [20], p. 94) yet formulated his most striking contrast between his company and Manichaeism years before his critic's protest. In his Concerning The True Religion, Augustine asserted that God assisted "virtuous readers" to comprehend their faith's sacred texts, whereas the Manichaean specialists, who proved to be unable to break their bad habits (consuetudinem suam vincere nequeunt), were destined to misconstrue the meaning of those texts, because they posited a powerful evil, independent of good (and of God), to justify their powerlessness. What started as a character flaw turned into a cognitive crisis; Augustine saw no future for Manichaean exegesis and no good, enlightening result coming from cultic discourse among the Manichees ([21], 9.16).

Tam pauci, tam turbulenti, et tam novi: the Manichees were "so few, so confused, and so new," that they could not hope for lasting influence. Augustine suspected a glaring contradiction was responsible for their confusion. Their elite often frantically coached and implored listeners to trust them-behavior that belied the specialists' declarations that their doctrine's appeal was due to its self-evident rationality. "Rather than offering their followers reasons to believe [the leadership] demanded that they believe" ([3], 14.31). Augustine's polemics pulled no punches. Relentless and occasionally ruthless, he vilified the sect's teachers as "bloodless," unprincipled, "longwinded, and wretched." He acknowledged that he had learned from them, but he expressed his gratitude effusively to "the Catholic Church" for having convinced him to reject "absurdities" that the Manichaean charismatics proposed as truths. He urged tepid or "marginal" Manichees to renounce what he had rejected and to embrace what he had accepted, a more orthodox-and less "Persian"-faith, in which they "would not want for the companionship of and for conversations with erudite, truly Christian teachers. Nor would they want for the books and serenity to search them and to sift their thoughts to discover more readily the truths they tried to find" among the Manichees ([3], 18.36). ${ }^{4}$

Although he endorsed measures formulated to coerce Donatist Christians to end their schism, Augustine was uninterested in persecuting Manichees ([24], p. 214; [25], pp. 81-86). Perhaps he remembered the effects of anti-Manichaean edicts on his career. He moved from Carthage to Rome and then to Milan to avoid regional officials trawling for Mani's admirers. After he defected, during the $420 \mathrm{~s}$, enforcement became especially relentless ([12], 2, 176), yet crisis is now

4. Ita tibi neque praecepta et disputations doctissimorum hominum et vere christianorum, neque libri, neque serenae ipsae cogitations defuerint quibus facile quod quaeris invenias. For Augustine's complaints about the Manichees' inconsistencies in this polemic, see [9], pp. 433-34; for his interests in (and appeals to) "marginal" Manichees, see [22], p. 191. But, predictably, as Johannes van Oort astutely notes, such a mission tempted Augustine to make some exegetical blunders [23], p. 138. 
acknowledged by scholars who tend to agree with Max Weber to breed charismatic leadership. Crisis can elicit the courage, nobility, ingenuity, agility, and exceptional sensitivities to context, traits that line up well with what Weber recognized as charismatic virtuosity and with the profound inspiration he expected charismatic leaders to provide [26]. Government officials supplied the political crisis that kept followers attentive to the Manichaean elite, the teachers populating this study as charismatic specialists, but a crisis of intelligibility was equally-or conceivably more-responsible for the specialists having received special status.

Christians demanded explanations. Their religion's statements about God, good, and evil raised questions, for which the Manichaean specialists claimed to have answers. At first, and for years, Augustine trusted them. But he came to understand the enormity of the challenge and his charismatic colleagues' inability to meet it: non solum homines sed etiam insipientes homines sumus; "we are not only human but unwise," having finite minds incapable of comprehending infinite truths ([1], 1.7.11). ${ }^{5}$ Hence, God's assistance was indispensable, and no teacher could do what only an ardent seeker's submission to truth in faith could accomplish. Faith, accompanied by desire and virtue made the difference ([3], 10.24). Of course there were Christian specialists affiliated with emergent orthodoxy, whom the Manichaean elect censured, but to whom seekers might repair for assurances that the mysteries of their faith were both beyond knowing, yet true. Augustine maintained that mainstream Christianity's scholars and church administrators, unlike Manichaean specialists, were uncharismatic and, as noted, cared nothing for notoriety ([3], 2.4).

For their part, the Manichaean elect seem to have conformed to what is now expected of charismatic leaders; they crafted a claim to superior righteousness and knowledge to undermine conventional norms, "exercis[ing] diffuse and intensive influence over [others'] normative and ideological orientations" ([11], pp. 459, 465-66). Augustine was alarmed by precisely that. He was indignant and distressed. He allowed, however, that his indignation promptly turned to pity whenever he pondered his former friends' inability to resolve the crisis of intelligibility with the reasons proffered by Manichaean specialists who seemed to be incapable of knowing their own "unknowing" (insipientia) and of discerning the signs of God's love in the church's sacraments ([2], 9.4.8).

Jason Beduhn's excellent, comprehensive study of the Manichaeism and anti-Manichaeism of Augustine's early years identifies the "recurring part[s]" of his protagonist's "outlook." He supposes that a "predilection for esotericism" first attracted his protagonist to Manichaean versions of Christianity and held his interest for nearly a decade. Disenchanted eventually with the sect's elect and drifting away, during his interviews with Faustus-if not before-from its cultic discourse, Beduhn's Augustine retained "high expectations of revealed knowledge" yet disavowed the expectation that complete sanctification and comprehension could come upon any of the sect's specialists. Augustine figured that insight came with faith, and faith was the onset of "a gradual

\footnotetext{
Cornelius Mayer elaborates on Augustine's passage, linking it with Plato's sense that a cloud of unknowing (eine Wolke der Torheit) separates seekers from the enlightenment they desire ([27], p. 60, and Carol Harrison usefully comments on the problems of theodicy that posed "seemingly unanswerable questions," creating, for Christians, what I term a crisis of intelligibility ([18], pp. 74-75).
} 
conformation to a system as one learns it more thoroughly and keeps adjusting one's sense of self' ([8], pp. 241-43).

The founder of Manichaeism might have agreed, to a point. The sect's listeners were gradually "adjusting" as they learned the truths imparted by the elect and understood that the temptations to wickedness which they experienced were symptoms of a powerful evil other's seizure; their wills were captive. But the charismatic specialists who succeeded Mani and who purportedly resisted temptation lay claim to authority on the strength of that resistance, which-with acquired intelligence that enabled them to ascertain the presence and power of evil as well as the presence of Light in creation-distinguished them from listeners, learning and "adjusting" gradually. Augustine joined the chorus of complaints prompted by such a distinction. The first antiManichaean script, the Acta Archelai, was circulating fifty years before he heaped abuse on Mani's pretensions. It supplies accounts of two debates said to have occurred between Mani and Archelaus, bishop of Carchar, located in Persian territory, one hundred-or-so miles from Roman garrisons. According to the Acta, the bishop prevailed in both confrontations. Mani twice fled, and the description of his humiliations introduces an extremely unflattering biography of the vanquished, to which sketches of others are annexed to show that Mani, "devious" as well as defeated ([28], 26.6), stole his ideas from previous mythmakers. Nothing about Mani appears unassailable; his originality, honesty, and intelligence were casualties of what still reads as a fractiously effective effort to undermine his celebrity and authority. Did Augustine know of Archelaus's scalding accusations? Perhaps so, inasmuch as Faustus looks to have been contemplating a reply during his studies in Carthage ([8], p. 331, note 15).

If a reply was composed and circulated, it got lost, yet historians have lately engaged in the rescue Faustus might have tried; the recovery of long lost Manichaean literature has helped them rehabilitate Mani's reputation. Hence, few scholars familiar with Christian antiquity would now dissent from the favorable observations on offer in Geo Widengren's concise introduction to Mani and Manichaeism, which was published in the 1960s and which featured Mani's "vigorous sense of mission." Widengren's Mani comes across as impressively resourceful. "Ahead of his time" he had a gift for "blend[ing]" ritual with reasoning and exhibited "astonishing vigor and versatility" ([29], pp. 140-44). It seems reasonable to infer that Mani similarly struck the author of the Acta (andarguably-Archelaus as well), because the polemic went to such great lengths to deploy what Eszter Spät now calls "romance elements" and ad hominem sidebars to discredit him [30]. What we learn from late antique heresiology as well as from Mani's relatively recent recuperation, however, enables us to dock him (and the Manichaean specialists who succeeded him) alongside Weberian standards for charisma and the popular notions described by Dickson [26]. Surely we should take Mani's insistence that he was the Paraclete, the divine spirit whose return had been forecast in the Gospel of John, as a bid for exceptional status, often awarded heroes of the faith and incarnatedeities-turned-inspirational-leaders ([28], 37.3). And Mani's now touted versatility, evident in his mixing Persian myth-as well as other ingredients-with Christian faith ([31], p. 212) suggests that he ought to be reckoned among charismatics who, Dickson astutely notices, become impresarios of their own celebrity. But what distinguishes Mani from the conventional members of that unconventional corps - and what will bring Augustine back into our story, is the function of scandal. 
As Dickson rightly says, in the second and un-Weberian sense of charisma, a charismatic leader, performer, or seer may be well served by "a whiff of scandal" [26]. Yet Augustine knew that scandal discredits Manichaean specialists' claims to superior righteousness and truth. They boasted of possessing both. Colleagues studying charismatic leadership of late suggest scandals diminish the effectiveness of the "techniques" that bind charismatics to followers; when high standards for - and the professed values of - charismatic leaders are compromised, followers' attachments to those charismatics' "ideological vision[s]" erode ([11], p. 453).

Augustine was intent on turning the "whiff" or scent of scandal into a stink. According to François Decret, his objective was "to aggravate the tensions" between the sect's "aristocracy of virtue" and other Manichees who presumed their charismatic leaders would be virtuous. Decret thinks the tension was characteristic of the Manichees' organization-the structure ecclésiastique, which, admittedly, is hard to reconstruct ([12], 1, p. 35). Still, we have learned that Augustine appreciated sect solidarity and prized intellectual conversations with amiable colleagues. He explained that friendships kept alive his hopes that swaggering charismatic specialists might reveal something meaningful. But he later declared that those friendships were the links in a chain choking him (sinuosum vinculum) and sustaining his unrealistic expectations of what Manichaean specialists would divulge ([32], 9.11).

Augustine wanted answers and was led to believe that Faustus would furnish them. He later referred to what he got as nonsense, nugae ([8], pp. 103-105; [10], 23.25), yet he thought that it was treacherous nonsense. One can imagine him overcoming his disappointment more easily after converting to a less gnostic Christianity and avoiding a long controversy with his former colleagues - or at least sheathing his polemical sword sooner-had he not become convinced that Manichaean specialists were drawing away the faithful by misconstruing ("mangling") Christianity's sacred texts. They and he agreed: a consensus evangelistarum constituted the bedrock of revelation and had to be both formulated and explained to more imperceptive Christians. To do so, the sect's elite exegetes had tossed aside the Hebrews' contributions to Christianity's sacred literature and proposed purportedly rational—but, to Augustine, chillingly heretical - interpretations of what remained. Manichaean specialists imagined duels everywhere; they depicted the cosmos as a battlefield on which God and the good fought evil. The Old Testament had to be jettisoned for the New to be true. Duels and dualism made the world intelligible to them. They refused to trust what Augustine perceived finally as "a single master purpose" after his faith in a "secure providential order of things" disposed him to give the Manichees' "fatalistic indeterminism" a pass ([8], pp. 264-65).

Reflections on exegesis, dualism, and doctrine tell much of the tale, but Augustine's disaffection during the 380s was also a reaction to the sect's charismatic specialists' - to him - determinedly indecorous behavior and disingenuous claims. In a study that rarely touches on Augustine's developing antagonism toward the Manichaean elect, Peter Brown noticed that his subject transferred affections encouraged in late Roman culture, specifically, the "deep warmth for teachers and spiritual guides," to Christianity's martyrs. "Heavy with the humility of human death" ([33], pp. 59-60), the martyrs could not scuttle, or mangle texts or wed rationality to the Christian faith to the detriment of the latter, or misbehave and spawn scandals. The martyrs were intermediaries, much as the Manichaean specialists, but they would not do what the latter ("false, deceitful men") 
had done to Augustine. They could not "dig up" (effodere) the seeds of the truth his mother planted in him; they would not have distracted him and kept him from returning to the emergent, orthodox Christian faith for over a decade ([33], 1.1).

Jason BeDuhn appropriately warns against exaggerating Augustine's transformation-his apostasy from Manichaeism and conversion to Nicene Christianity. A reasonable reading of the relevant texts suggests that he subordinated a desire for "self-intelligibility" to related "systems" of Christianity, finding "that he constantly had to reinvent what his conversion would mean for him as he continued to discover the potential of his adopted system and of himself as its point of articulation "in the face of the Manichaean challenge" ([8], pp. 301-302). Still, by the late 380s, he was reluctant to trust enterprising and ostensibly compelling figures who, in the judgment of others, were celebrated guides. Faustus disappointed him. Bishop Ambrose of Milan, who was an astute administrator and charismatic Nicene (or mainstream) Christian - and whose oratory he admired-became more a foil than a friend and regular correspondent ([25], pp. 15-24). It would appear that Manichaeism left Augustine suspicious of charismatics' claims upon devotees' credulity. And his suspicions endured as other "specialists"-Christian continetes, Donatist bishops and martyrs, and Pelagian moral theorists - displayed what he perceived as pride in acquired virtues.

\section{References}

1. Augustine. De moribus ecclesiae Catholicae et de moribus Manichaeorum.

2. Augustine. Confessiones.

3. Augustine. De utilitate credendi.

4. J. Kevin Coyle. Manichaeism and Its Legacy. Leiden: Brill, 2009.

5. Augustine. Contra Faustum Manicheum.

6. François Decret. Aspects du Manichéisme dans l'Afrique Romain. Paris: Études Augustiniennes, 1970.

7. Andreas Hoffmann. Augustinus Schrift, "De utilitate credendi”. Münster: Aschendorff, 1997.

8. Jason David BeDuhn. Augustine's Manichaean Dilemma, 1: Conversion and Apostasy, 373-388 C.E. Philadelphia: University of Pennsylvania Press, 2010.

9. Johannes van Oort. "Manichaean Christians in Augustine's Life and Work." Church History and Religious Culture 90 (2010): 505-546.

10. Augustine. Contra epistulam Manichaei quam vocant Fundamenti.

11. C. Marlene Fiol, Drew Harris, and Robert House. "Charismatic Leadership: Strategies for Effecting Social Change." Leadership Quarterly 10 (1999): 449-82.

12. François Decret. L'Afrique Manichéenne (IV $V^{a} V^{a}$ siècles). Paris: Études Augustiniennes, 1978, 2 vols.

13. Richard Lim. Public Disputation, Power, and Social Order in Late Antiquity. Berkeley: University of California Press, 1995.

14. Sabine MacCormack. “Augustine Reads Genesis.” Augustinian Studies 39 (2008): 5-47.

15. Roland J. Teske, S.J. "The Heaven of Heaven and the Unity of St. Augustine's Confessions." American Catholic Philosophical Quarterly 74 (2000): 29-45.

16. L.J. van der Lof. "Der numidische Manichäismus im vierten Jahrhundert." Studia Patristica 8 (1966): 118-29. 
17. Peter L. Brown. Augustine of Hippo: A Biography. Berkeley: University of California Press, 2000.

18. Carol Harrison. Rethinking Augustine's Early Theology. Oxford: Oxford University Press, 2006.

19. Augustine. Contra literas Petiliani.

20. Jason David Beduhn. "Augustine Accused: Megalius, Manichaeism, and the Inception of the Confessions." Journal of Early Christian Studies 17 (2009): 85-124.

21. Augustine. De vera religione.

22. Annemaré Kotzé. "The Anti-Manichaean Passage in Confessions 3 and its Manichaean Audience." Vigiliae Christianae 62 (2008): 187-200.

23 Johannes van Oort. "Augustin und der Manichäismus." Zeitschrift für Religions-und Geistesgeschichte 46 (1994): 126-42.

24. Madeleine Scopello. 'L'Epistula Fundamenti à la lumière des sources manichéennes du Fayon." In Augustine and Manichaeism in the Latin West, Johannes van Oort, Otto Wermelinger, and Gregory Wurst, Eds. Leiden: Brill, 2001, 205-221.

25. Peter Iver Kaufman. Incorrectly Political: Augustine and Thomas More. Notre Dame: University of Notre Dame Press, 2007.

26. Gary Dickson. “Charisma, Medieval and Modern.” Religions 3 (2012): 763-789.

27. Cornelius Mayer. "Garanten der Offenbarung: Probleme der Tradition in den antimanichäischen Schriften Augustins.” Augustinianum 12 (1972): 51-78.

28. Hegemonius. Acta Archelai. Louvain: Brepols, 2001.

29. Geo Widengren. Mani and Manichaeism. New York: Holt, Rinehart, and Winston, 1965.

30. Eszter Spät. "The 'Teachers' of Mani in the Acta Archelai and Simon Magus." Vigiliae Christianae 58 (2004): 1-23.

31. Madeleine Scopello. "Vérités et contre-vérités: La vie de Mani selon les Acta Archelai." Apocrypha 6 (1995): 203-24.

32. Augustine. De duabus animabus.

33. Peter L. Brown. The Cult of the Saints: Its Rise and the Function in Latin Christianity. Chicago: University of Chicago Press, 1981. 
Reprinted from Religions. Cite as: Whalen, B.E. "Antichrist as (Anti)Charisma: Reflections on Weber and the 'Son of Perdition'." Religions 4 (2013): 77-95.

\title{
Antichrist as (Anti)Charisma: Reflections on Weber and the 'Son of Perdition'
}

\section{Brett Edward Whalen}

\begin{abstract}
The figure of Antichrist, linked in recent US apocalyptic thought to President Barack Obama, forms a central component of Christian end-times scenarios, both medieval and modern. Envisioned as a false-messiah, deceptive miracle-worker, and prophet of evil, Antichrist inversely embodies many of the qualities and characteristics associated with Max Weber's concept of charisma. This essay explores early Christian, medieval, and contemporary depictions of Antichrist and the imagined political circumstances of his reign as manifesting the notion of (anti)charisma, compelling but misleading charismatic political and religious leadership oriented toward damnation rather than redemption.
\end{abstract}

\section{Introduction: Obama, Antichrist, and Weber}

On 4 November 2012, just two days before the most recent US presidential election, Texas "Megachurch" pastor Robert Jeffress (1956- ) proclaimed that a vote for the incumbent candidate Barack Obama (1961- ) represented a vote for the coming of Antichrist. "President Obama is not the Antichrist," Jeffress qualified to his listeners, "But what I am saying is this: the course he is choosing to lead our nation is paving the way for the future reign of Antichrist" [1]. Over the last four years, other evangelical Christians and additional critics of the president have been less circumspect about the apocalyptic implications of Obama's presidency and his identity as Antichrist. One popular email-chain that made the rounds in the fall 2008 alerted readers, referring to the Book of Revelation as its source:

The anti-Christ will be a man, in his 40s, of MUSLIM descent, who will deceive the nations with persuasive language, and have a MASSIVE Christ-like appeal....the prophecy says that people will flock to him and he will promise false hope and world peace, and when he is in power, will destroy everything. Is it OBAMA? [2].

Naysayers have refuted this particular claim, pointing out (among other things) that the Book of Revelation says nothing directly about Antichrist, his age, or his status as a Muslim. The association of Barack Obama with Antichrist, however, will not be easily turned aside. One video posted on Youtube from January 2009, titled "Is Barack Obama Antichrist?" opens with scenes of Hitler and his mesmerizing political performances before cutting to scenes of Obama on the 
campaign trail in 2008 [3]. The implications are clear. This video goes on to claim that certain letter-sequences in the Book of Revelation link Obama to Antichrist. As of December 2012 it has garnered close 1.5 million hits. A more recent video posted in September 2012 confidently declares "The Antichrist is Barack Obama." While ominous music plays in the background, this production combines scriptural citations with recent clips from the media to assert that the president meets an impressive 14 out of 16 characteristics required for being Antichrist [4].

As an elected office holder, the executive leader of a massive - one is tempted to say Byzantine - bureaucratic governmental system, Barack Obama does not at first glance fit the bill for a bearer of "charismatic" authority as defined by the German sociologist Max Weber (1864-1820) ([5], pp. 18-27; [6], pp. 46-47). Obama's association with Antichrist, however, speaks to possible connections between the U.S. president and Weber's model of charisma, framed not just in historical but eschatological terms. Looking beyond Obama specifically, Antichrist suggests a fascinating portrait of inverse Weberian charisma in action, what one might call (anti)charisma, charisma with a reverse charge or polarity. After all, who or what is Antichrist? As commonly understood, the Christian idea of Antichrist posits the coming of a false prophet, a deceptive miracle-worker, a person filled with the spirit of evil who will attract throngs of followers believing in him as the true messiah during the trials of the end-times ([7], pp. 1-7). (Anti)charisma in this regard does not mean the opposite of charismatic authority, which might be called "anti-charisma." Anti-charisma suggests perhaps nothing more than the extreme "routinization" of charisma, as Weber called it, whereby charisma metamorphoses into institutional rule by officials and laws, into leadership without the personal, compelling appeal of the charismatic king or prophet or other leader ([5], pp. 48-65). Rather, (anti)charisma denotes a "dark" charisma, what today we might call the "cult of personality," an immediate, inspirational, and compelling act of creating what seems to be legitimate authority and a sense of prophetic mission — but turns out to be a misleading guide into political and perhaps eternal damnation rather than redemption.

\subsection{Barack Obama as Antichrist/Messiah}

Obama is hardly the first U. S. president or major contemporary political figure to be linked with the eschatological figure of Antichrist, who plays the role of Satan's earthly minion during the apocalyptic trials and tribulations of history's end. As is often the case when a political leader's detractors denounce him in these terms, it remains difficult to gage the sincerity of these accusations in terms of religious conviction. Bernard McGinn has found it useful to distinguish between Antichrist language, using the term to attack opponents without any commitment to a vision of salvation history, and Antichrist application, representing a genuine effort to interpret historical events and personages as part of an apocalyptic scheme ([6], p. 21). One imagines that some contemporary Americans employ the label Antichrist as a provocative slur encapsulating their general dislike of the president, while others, especially Christians steeped in popular end-times scenarios, take the premise of his apocalyptic role quite seriously. Regardless, in Obama's case the question of his possible status as Antichrist assumes a far more elevated profile and sometimes emotionally intense condition than it did with his predecessors in office. Witness the heckler at a 2011 fundraiser in Los Angeles who screamed at the president "The Christian God 
is the one and only true living God" and "Jesus Christ is God" before yelling at him "you're the Antichrist!" [8].

The relatively widespread conviction or convenient slander that Obama is Antichrist seems to exist in an inverse relationship with the equally pervasive notion that Obama represents a messianic figure, a secularized civil savior for the American dream and political experiment. Referred to as "the One," he channels some of the qualities identified with a charismatic leader in the Weberian mode, inspiring something akin to hero-worship among some of his followers [9]. ${ }^{1}$ The blog "Is Barack Obama the Messiah" provides a clearing house for numerous articles, essays, videos, and excerpts from literature exploring various aspects of Obama's "messianic" or "prophetic" qualities (along with links to sources skeptical of such claims) [10]. For others, Obama's status as the One has grown to such proportions that it requires some gentle or not-so-gentle mockery. In his acceptance speech at the 2012 Republican National Convention, Mitt Romney played with this theme by making a side-ways reference to the issue of climate change, declaring "President Obama promised to begin to slow the rise of the oceans, and to heal the planet. My promise is to help you and your family" [11]. On occasions, even Obama has gotten in on the act, joking at the Alfred E. Smith Memorial Foundation dinner in October 2008 that "Contrary to the rumors you have heard, I was not born in a manger. I was actually born on Krypton and sent here by my father Jor-El to save the Planet Earth" [12]. For his opponents, however, this very idea of the president as a redemptive figure precisely illustrates the danger he poses to American society and provides vivid proof of Obama's Antichrist-like qualities - his ability to deceive the masses, tricking them into thinking that he is a messiah who can redeem the world. His very charismatic appeal condemns him, revealing him to be a false-messiah, whose meteoric rise to power portends evil deeds before the end of all things.

\subsection{The Scriptural Basis for Antichrist}

Contemporary Christians not familiar with the Bible might be surprised at the lack of direct scriptural attention paid to Antichrist given his prominent role in subsequent apocalyptic scenarios ([7], pp. 33-45). In the New Testament's so-called "Little Apocalypse" (Mk. 13:1-37; Mt. 24:1-15:46; Lk. 21:5-38), Christ warns his disciples of those who will come claiming to be the messiah during future tribulations that will include war, earthquakes, famines, and other forms of suffering. As he says in the Gospel according to Mark, 13:21-23:

And then if any man shall say to you, behold, here is Christ; behold, he is here: do not believe. For there will rise up false Christs and false prophets, and they shall show signs and wonders to seduce (if it were possible) even the elect. Take you heed therefore; behold I have foretold you all things.

Among other signs of the approaching end, the sun will be darkened, the moon will not shine, and the stars will fall from the heavens.

Christ also speaks about the "Abomination of Desolation" (Mk. 13:14-20), one of many references in the Little Apocalypse to the Old Testament Book of Daniel (including Dan. 11:31;

1 In her article "The Charisma Mandate," Zernike [9] explicitly discusses Obama during the 2008 campaign in the terms of Weberian Charisma. 
12:11). As interpreted by later Christian exegetes, Daniel provided a crucial source of scriptural support for the notion of Antichrist and apocalypticism more generally. This particular passage about the Desolation of Abomination "predicts" the profanation of the Jewish Temple by the Seleucid ruler Antiochus IV (r. 175-164) in the second century BCE, the same period as the book's final redaction. For the first generation of Christians, the Roman sack of Jerusalem in 70CE seemed to confirm the Abomination of Desolation as again prophesized by Christ. By the second and third centuries, however, Christians understood the Abomination of Desolation as referring to a future figure of the evil and persecution, the "the Son of Perdition" described in Second Thessalonians (II Thess. 2:1-12). Second Thessalonians provides the most detailed predictions in the Bible about the coming of Antichrist (albeit without using that precise label). As Paul writes:

And then that wicked one shall be revealed whom the Lord Jesus shall kill with the spirit of his mouth, and shall destroy with the brightness of his coming, him, whose coming is according to the working of Satan, in all power, and signs, and lying wonders, and in all seduction of iniquity to them that perish, because they receive not the love of the truth, that they might be saved. Therefore God shall send them the operation of error, to believe lying: That all may be judged who have not believed the truth, but have consented to iniquity.

For Paul, the "wicked one" is an individual figure, whose coming will only occur after the "restrainer" or "restraining force" gives way. As discussed below, early Christians typically understood this restraining force as a reference to the power of the Roman Empire, meaning that Antichrist would not arrive until Roman power failed ([7], pp. 43, 61-62).

\subsection{Antichrist as Corporate Evil}

At this point, one should also take note of an alternative notion of Antichrist as a corporate entity rather than individual figure, paralleling the "body of Christ" as the assembly of the faithful ([7], p. 78). Although the first letter of John 2:16-21 indicates the coming of Antichrist at the "last hour," this biblical text suggests a collective sense of Antichrist as anyone who denies God the Father and the Son. For patristic Christian theologians such as Augustine of Hippo (354-430), this idea of a corporate Antichrist held great appeal as a far safer mode of historical interpretation. Augustine did not deny the future reality of Antichrist as an individual who will come to persecute the faithful during the end of days. Nevertheless, in works such as his magisterial City of God, he spent little time indulging in the imagined details of Antichrist's reign. As is well known, by his mature phase of thinking, Augustine opposed overt forms of apocalyptic speculation about the future course of history, including the notion that there would be a transformative millennial age of peace and justice on earth after the defeat of Antichrist along with the "binding" of Satan (Rev. 20: 1-2) and the coming of the Lord in Final Judgment. For Augustine, such fantasies about a Sabbath age were fit only for "carnal-minded" Jews and heretics, distracting from the true eschatological culmination of history in God's eternal kingdom ([7], pp. 76-77; [13,14]). In this regard, Augustine and other conservative patristic figures emphasized the nature of Antichrist as the collective embodiment of those things, peoples, and deeds opposed to Christ, creating an influential counterweight to the individual "Son of Perdition," discussed here as an anti(charismatic) individual coming at the end of time. 


\subsection{Historical Antichrists}

Another important view of Antichrist orients our attention on the past rather than the future, looking back into history for representatives of Antichrist's power that anticipate the coming of the final Antichrist. In such scenarios, Antichrist typically represents an external force of outright persecution against the elect, rather than some sort of (anti)charismatic figure who would lead the faithful astray from within. The Roman emperor Nero (r. 54-68) emerged as such a persecutory figure in early Christian views of apocalyptic evil, associated with the initial pagan attacks on the Christian Church in the first century CE ([7], pp. 45-54). Later Roman emperors often joined this list of persecutors until the fourth-century conversion of Constantine I (306-337) to Christianity. Even after Constantine, heretical Christian Roman emperors, such as the Arian ruler Constans (r. 337-350), could still function as a representative of Antichrist's evil power. (For that matter, "heretical" groups like the Donatists in northern Africa continued to view Constantine as a persecutory, anti-Christian figure even after his conversion to "orthodox" Christianity.) As discussed below, after the rise of Islam in the seventh century, Christians located another external source of apocalyptic persecution against the Church in the Muslim community, associating Muhammad with Antichrist [15].

The notion of multiple historical Antichrists remains operative in contemporary American apocalyptic thought, although it does not occupy the same prevalent place as it did in medieval theology of history. Those who subscribe to the idea that Obama represents Antichrist sometimes hedge their bets on whether he is the final Antichrist or one more historical manifestation of Antichrist's evil. As noted above, the video titled "Is Barack Obama the Antichrist" links Obama with past figures of anti-Christian wickedness by opening with clips of Hitler's demagoguery in action, followed by still-shots of Obama speaking to equally captivated crowds. Obama is also associated with Stalin and Mao in a similar fashion ([3], pt. 1). (Contrariwise, messianic-narratives link Obama with figures such as Gandhi and Martin Luther King Jr., suggesting his status as the most recent manifestation in a line of redemptive peace-making prophets.) In this regard, one can easily target a political figure like Obama as one of many Antichrists without firmly committing to any sort of imminent apocalyptic scenario.

\subsection{Christ-Antichrist/Charisma-(Anti)Charisma}

The most compelling and best-known theory of Antichrist remains the projection of an individual figure that will come just before the end of time and effectively seduce the faithful through his (anti)charismatic leadership before beginning the open persecution of the elect. For Weber, charisma denotes a "natural leader," the holder of "specific gifts of the body and spirit" ([5], pp. 18-19). The charismatic individual is "set apart from ordinary men and is treated as endowed with supernatural, superhuman, or at least specifically exceptional powers or qualities" ([5], p. 48). His faithful followers recognize and thereby validate the charisma-bearer's mandate to lead. ${ }^{2}$ Genuine charisma cannot exist without devotion, a devotion "born of distress and

2 As noted by Gary Dickson in the introductory essay to this volume, Weber does not seem to have explicitly addressed the possible qualities and characteristics of specifically female charisma. 
enthusiasm" ([5], p. 23). Charismatic authority stands "outside the realm of everyday routine and the profane sphere" ([5], p. 51). In Weber's analysis, the "prophet" represents a particular manifestation of legitimate authority, a "purely individual bearer of charisma, who by virtue of his mission proclaims a religious doctrine or divine commandment" ([5], p. 253). Jesus Christ (along with Zoroaster and Muhammad) numbers among his examples of such prophetic charisma, demonstrated through magic, miracles, and other displays of power such as exorcizing demons. "The entire basis of Jesus' own legitimation," Weber writes, "was the magical charisma he felt within himself. It was doubtless this consciousness of power, more than anything else, that enabled him to traverse the road of the prophets" ([6], p. 270).

If Christ represents a classic example of Weberian charismatic authority, one might reasonably consider the case of Antichrist as a projection of (anti)charisma, an example of a "false prophet," a simulacrum of the messiah expected at the end of days. Charisma, viewed through the lens of the Antichrist tradition, takes on a negative rather than positive charge. In this regard, charisma can be imagined as part of the "profane sphere," albeit understood as (anti)charisma. One might object that Antichrist is an eschatological fiction, a theological and literary construction with no basis in reality as a historical personage. For our purposes here, this hardly seems important. Except for his earliest followers, and for mystics claiming a direct encounter with Jesus, Christians have known (and still know) Christ's prophetic authority as a textual phenomenon mediated through the narrative of the New Testament. Christ and Antichrist both exist within the framework of Christian hermeneutics, and both provide a locus for the consideration of Weberian charisma/(anti)charisma.

\section{2. (Anti)Charisma and End-Times}

According to Weber, charismatic authority flourishes in times of "psychic, physical, ethical, religious, political distress" ([5], p. 18). The period preceding the end of the world, as typically imagined by medieval and modern Christian apocalyptic thinkers, will unmistakably meet such conditions of crisis and upheaval. Antichrist's individual (anti)charisma depends upon, harnesses, and enhances this disruption. As developed over time, the projected life of Antichrist functions like photo-negative of Christ's story in the Gospels, including his charismatic preaching, miracles, and overall ministry. As the ultimate false prophet in a time of political, economic, and natural disorder, Antichrist encapsulates the very same qualities and characteristics of prophetic-messianic charisma as envisioned by Weber in a state of reverse polarity-oriented toward damnation rather than redemption. 


\subsection{Antichrist's Medieval Life}

Vague as it is, the biblical scenario for an individual Antichrist promises the coming of the Son of Perdition, who will profane the rebuilt Temple in Jerusalem, perform miracles, and deceive many into recognizing him as the messiah. Early Christian theologians did not offer much in the way of personal details about the life of Antichrist, but they did expand upon his apocalyptic role. According to Irenaeus (c. 140-202) in book five of his Against Heresies and Hippolytus (c. 170-235) in his tract On Christ and Antichrist, Antichrist will be a Jew born from the tribe of Dan, who will defeat the ten petty kings of the world and unite unbelievers everywhere under his reign before persecuting the elect who refuse to acknowledge his rule ([16], pp. 121-28; [17]). In these early Christian scenarios, Antichrist will reign for three-and-a-half years - a figure based on the forty-two months referenced in Revelation (Rev. 11:3) — before the Second Coming of Christ, who will cast him down before the defeat of Satan and Final Judgment. According to some early Christian and medieval thinkers, God will allow a period of "rest" for those who lapsed during the trials of Antichrist to do penance, a space of time that offers a corollary of sorts to the notion of the millennium as an age of peace and justice on earth before coming of God's kingdom [18]. In such works, however, details about the life of Antichrist are scant. For the most part, exegetes tried to demonstrate the scriptural basis for the very notion of Antichrist and the overall Christian apocalyptic scenario, rather than dwelling upon the narrative elements of what Antichrist's life would look like [19].

This lack of descriptive embellishment changed in the Middle Ages. In the tenth century, the popular work On the Birth and Time of Antichrist by the French abbot Adso of Montier-en-Der (d. 992) offered a highly influential "biography" of Antichrist, drawing together various earlier traditions into concisely packaged exposé on the end-times ([20], pp. 20-30; partial translation in [21], pp. 82-87). Adso's work formed something like a standard view of Antichrist over the following centuries, modified and incorporated into various textual settings including prophecies and biblical exegesis. Adso structured his vision of the Son of Perdition around the basic notion that Antichrist "will be contrary to Christ in all things, and do contrary things to Christ" ([20], p. 22; [21], p. 84). Antichrist will be a Jew from the tribe of Dan, born from the sexual union of a man and women, not from a virgin birth as some claimed. He will, however, be conceived in sin, with the spirit of the Devil filling the woman's womb just like the Holy Spirit filled Mary. Born in Babylon, raised in Bethsaida and Corozaim, Antichrist will be raised "in every iniquity" by "magicians, sorcerers, soothsayers, and wizards," who will train him in black arts. Eventually, he will come to Jerusalem, persecuting those Christians that he cannot convert to his cause, and install himself in the rebuilt Temple of Solomon ([20], pp. 24).

Displaying miracles, a key characteristic of Weber's prophetic form of charisma, will represent a crucial component in Antichrist's rise to power. According to Adso, Antichrist will produce "great and unheard of miracles," calling fire from heaven, making trees to flower suddenly and wither, disturbing and calming the seas, changing the winds, and raising the dead. He will even pretend to die and after three days come back to life like Jesus. He will thereby try to "lead the elect into error." "For when they see so many and such great signs, those who are perfect and the elect of God, they will doubt whether or not he is Christ, who will come at the end of the world, 
according to Scripture" ([20], pp. 24-25). For three-and-a-half years, Antichrist will reign over the elect with terror, gifts, and miracles, seeking to frighten them, bribe them, or seduce them into submission. At the beginning of his open persecution of the election, he will kill the two prophets, Enoch and Elijah, who will be sent back by the Lord to comfort the faithful. The Jews, Adso also notes, will flock to him and recognize him as the messiah. Finally, Antichrist will prepare for his own ascension on Mount Olives; before this can happen, however, Jesus Christ will return to triumph over him. Either Christ or the archangel Michael will slay Antichrist, ending his reign ([20], pp. 27-29).

As pointed out by Richard K. Emmerson, Adso's vita of Antichrist effectively forms a work of "anti-hagiography," that is, an inverted saint's life, wherein good becomes evil, miracles become sorcery, and the Holy Spirit becomes the Spirit of Lies [22]. Just as saint's lives drew upon Christ as their model and inspiration, the vita of Antichrist closely parallels the life of Christ as revealed in the Gospels. Yet, as Emmerson points out,

Antichrist imitates only the outward forms of Christ's life. His is essentially the opposite of Christ, a parodic imitation of the Savior in order to more effectively deceive the world. Although apparently like Christ, Antichrist is actually 'contrary' to Christ, 'id est Christo contrarius.' Nevertheless, Antichrist's false imitatio Christi in order the better to deceive the faithful in the last days underlies many of his actions, from birth to death. In other words, the events in the life of Antichrist parallel those of Christ ([22], pp. 184-85).

Emmerson's point is well taken. Antichrist is not the true messiah. The "outward" parody of Christ's life by Antichrist, however, is not just skin-deep. As imagined in this corollary status to Christ, Antichrist embodies an (anti)charismatic authority equally as persuasive as Christ's, filled with (evil) spiritual inspiration and miraculous_-albeit deceptive-powers.

\subsection{Antichrist's Modern Life}

Passing over later medieval and early modern depictions of Antichrist, one can chart out some basic biographical characteristics of Antichrist in the popular American imagination, above all associated with forms of "pre-millennial dispensationalism," that is, predominantly evangelical Protestant beliefs involving the Rapture (when the elect will be taken up into the skies), a sevenyear Great Tribulation (including the reign of Antichrist), and the coming of Christ and battle of Armageddon followed by a thousand-year kingdom of peace and justice on earth before Final Judgment. Although the details vary, the life of Antichrist will be characterized by his rapid rise to power, his creation of false world peace, and his unleashing of horrible persecution against those who reject his authority.

In his best-selling book The Late Great Planet Earth, first published in 1970, Hal Lindsay (1929- ) offers what has become a more or less typical contemporary American description of Antichrist ([23], pp. 98-113). He skips over the early life of Antichrist (the details of which are captured for many modern observers in the 1976 movie, The Omen), presenting the Son of Perdition or "the Great Dictator" as a political figure of astonishing acumen. He will be European, emerging from the "restored" Roman Empire with "an air about him that is self-assured and proud" 
([23], p. 106). Miracles, again, will play a key component in the narrative of his meteoric rise to (anti)charismatic authority, seducing the faithful along the way. As Lindsay warns his readers:

Satan himself is going to give him fantastic power. This is one reason that Christians should not get too excited when they see a miracle. It may not be a miracle of God. Satan is a miracle-worker and he has been able to work miracles from the beginning...Satan is going to send this man, his masterpiece, with all sorts of signs and wonders and miracles ([23], p. 106).

Recovery from what seems to be a fatal wound (a reference to Rev. 13:3) will be one miraculous sign of Antichrist's identity and a parody of Christ's resurrection. For Lindsay, the Antichrist will hold sway as a demagogue, through the force of his personal, charismatic qualities: "He will have a magnetic personality, be personally attractive, and a powerful speaker. He will be able to mesmerize his audience with his oratory" ([23], p. 108).

Lindsay in fact cautions against associating any given political figure with Antichrist ([23], p. 113). Nevertheless, in sermons, popular media, and on the Internet the temptation to do so seems far too great to resist, above all during the recent years of the Obama administration. This overall vision of Antichrist clearly informs the 2008 email-chain suggesting that Barack Obama might be Antichrist: a man in his 40s (presumably hale and handsome, in the prime of his life), who will trick people with "persuasive language" and possess "massive" Christ-like appeal. In recent years, Lindsay's prediction that Antichrist will be European has clearly given way to the far more immediate anxiety that Antichrist will be an American political leader, although, in Obama's case, one could argue that he is a foreigner rather than a "real" American. Although not always explicit in the discussions of Obama as Antichrist, the claim of the so-called "birthers" that Obama's Hawaiian birth-certificate is a fake and that he was actually born in Kenya complements this scenario nicely [24]. The belief that Obama is a Muslim, and that Antichrist will be a Muslim, makes Obama's ambiguous status as an (false) insider and (deceptive) outsider apocalyptically unmistakable. As an end-times figure, Obama is anti-American, anti-Christian, and (anti)charismatic all rolled into one.

\subsection{The Political Landscape of the Apocalypse}

The Antichrist tradition places a particular emphasis on the political circumstances that will accompany the reign of Antichrist. Specifically, drawing upon the Book of Daniel and Nebuchadnezzar's dream of the alloyed statue (Dan. 2), the apocalyptic scenario for the reign of Antichrist involves a progressive theology of history based on "world empires." The statute possesses a head of gold, chest and arms of silver, belly and thighs of bronze, legs of iron and feet of iron mixed with clay, representing a succession of deteriorating imperial powers. Christians also mapped the four world empires onto Daniel's vision of the four beasts (Dan. 7), including the fourth beast with ten horns, and a little horn (i.e., Antichrist) emerging from the others. These beasts, in turn, formed a source of textual inspiration for similar beasts featured in the Book of Revelation, including the huge red dragon with seven heads and ten horns (Rev. 12:3) and the beast from the sea (Rev. 13:1-3) with seven heads and ten horns. In the third century, Hippolytus described the situation in this way, declaring that "in distinguishing the kingdoms that are to rise after these things," Daniel's visions "showed also the coming of Antichrist in the last times, and the 
consummation of the whole world" ([17], p. 13). Hippolytus and other early Christians fixed this progression of empires on the Babylonians, the Persians, the Hellenistic Greeks, and finally the Romans. The feet mixed of iron and clay, along with the ten horns, represent the end-times fragmentation of Roman power into various kingdoms that will set the stage for Antichrist's rise to power ([17], pp. 13-18).

The emphasis on Roman power as the final world empire also connects with Second Thessalonians" description of a "restraining force" that will lapse just before the coming of Antichrist. By this logic, as long as the Roman Empire stands, the end will not — cannot—arrive. For the earliest Christians, periodically persecuted by Roman authorities from the first to the early fourth century, the status of Rome as the restraining force complemented the idea of the Roman as the "New Babylon," the "Whore" seated on the beast in Revelation 17. With the conversion of the Roman Empire to Christianity starting the fourth century, Christian apocalyptic attitudes toward the empire naturally became more ambivalent, but the idea of Rome as the restraining force endured. For thinkers like Saint Jerome and Augustine, both of them rather cool toward fervid apocalyptic speculation, the apparent collapse of Roman imperial power in Western Europe during the fourth and fifth centuries required them to generally downplay the idea that Rome's current political problems represented a clear and present sign of the end. For medieval thinkers, starting with Adso, the renewal of the imperial title under Charlemagne (r. 774-814) and the Carolingian dynasty, followed later by the Ottonians, Salians, and Hohenstaufens provided a neat solution to this problem. The Roman Empire had not fallen, but had rather been "transferred" to new bearers, leaving the restraining force in place [25].

Apparently, the Roman Empire has still not fallen. In modern apocalyptic scenarios, the tribulations of the end have widened to encompass all sorts of social ills and environmental disasters that medieval theologians could have scarcely imagined, including AIDS and global warming, not to mention traditional biblical trials such as earthquakes, famine, and war. The idea that the Roman Empire must endure until the closing chapters of history, however, has proven remarkably durable. In The Late Great Planet Earth, Hal Lindsay recycles the basic exegesis of Daniel (including the statue in Book 2 and four beasts in Book 7) to posit the progression of world empires leading up until his own day, when NATO, the European Common Market (formed from 10 nations, matching the "ten horns" or kingdoms featured in Daniel), the World Bank, and other institutions provided evidence of a reborn or reconstituted "Roman Empire" in Europe ([23], pp. 88-97). As Lindsay describes the situation, the "time is ripe and getting riper for the Great Dictator, the one who is predicted in the scriptures very clearly and called the "Antichrist"” ([23], p. 103). In more recent evangelical apocalyptic literature, such as the South Carolina-based periodical Midnight Call, the European Union and creation of the euro serve to further confirm the emergence of the political circumstances for the rise of Antichrist's (anti)charismatic authority [26].

In recent narratives of Obama's rapid rise to power, there are plenty of apocalyptic traumas to set the stage for his apparently messianic but deceptive leadership, including war, natural disasters, and the financial meltdown that started in late 2007. Fears that the United Nations might be plotting to invade the United States and deprive the country of its sovereignty, although not unique to the period of Obama's presidency, seem to overlap with apocalyptic anxieties that new forms of world government are setting the stage for Antichrist's reign. In any event, the promise of apocalyptic 
trauma continues to play a critical role in predictions about Antichrist's Svengali-like abilities to deceive the masses and lead them into error by dint of his magnetic personality and (anti)charismatic qualities. Trauma sets the stage for the misleading parody of Christ's prophetic role as a charismatic figure of redemption.

\subsection{Antichrist and Judaism}

From its earliest stages, Christian apocalyptic thinkers have assigned a prominent place to "the Jews" in their projected narratives for the end times, based in part upon the implication in Paul's letter to the Romans (Rom. 9:27; 11:25-26) that a "remnant" of the Jews will convert after the remaining Gentiles have embraced Christianity. Eschatological Jewish conversion to Christianity quickly became a staple of such Christian apocalyptic scenarios. As seen above, however, Jews hold a particularly uncomfortable place in the medieval end-times imagination. As noted by Adso among others, Antichrist will be a Jew; Jews will flock to him and serve him. This fraught position persists in modern dispensationalist scenarios, which argue that a Jewish presence is required in the Holy Land as a precondition for the apocalypse. In this reading of events, the foundation of the modern state of Israel formed an event of biblical proportions, as did the expansion of Israeli territorial control during the Six-Day War, including the capture of Jerusalem. An attack on Israel will help to usher in the final tribulations; Antichrist will establish himself in Jerusalem, profaning the rebuilt Temple; and the final battle between Christ and Antichrist will happen at nearby Armageddon. Around this time, the remnant of Jews-perhaps implying that many if not most of them will be destroyed as servants of Antichrist-will convert to Christianity [27]. One scene in the 2012 video "The Antichrist is Barack Obama" that features Obama (on his visit to Israel during his 2008 campaign) at the "Wailing Wall" seems particularly suggestive of the enduring notion that Antichrist will establish his rule in Jerusalem, rebuilding the Temple of Solomon ([4], min. 7:28).

As pointed out by Paul Boyer, evangelical apocalyptic thought about Jews should not just be seen as a "mask for anti-Semitism" ([27], p. 322). In Protestant dispensationalist schemes, one finds something close to a new philo-Judaism among Christians toward the Jews as God's original Chosen People, creating (among other consequences) a strong source of political support for Israel in American evangelical circles. Boyer asserts that such "positive pronouncements" about Jews "mark a major discontinuity between medieval and Reformation-era prophetic interpretations and those of the modern era" ([27], p. 323). To some extent Boyer is correct, although such apocalyptic philo-Judaism in fact predates modernity. As pointed about by Robert Lerner [28], Anna Sapir Abulafia [29], E. Randolph Daniel [30] and others [31], certain medieval Christians starting with highly influential twelfth-century apocalyptic thinker Joachim of Fiore (1132-1202) placed a remarkable emphasis on the irenic conversion of the Jews at the end of time, suggesting that they would resume their place as God's Chosen People, perhaps even retaining some element of the distinct identity as Jews in the millennial kingdom ([32], pp. 100-24). Joachim became one of the first - if not the first - Christian thinkers to break with the long-standing tradition that Antichrist would be a Jew and declared that the Son of Perdition would in fact be born a Christian ([33], pp. 566-70). In this regard, Christian apocalyptic scenarios have long been characterized by ambivalence toward Judaism that remains until the present. 


\subsection{Antichrist and Islam}

Christian apocalyptic attitudes toward Islam show far less uncertainty or conflicted- feelings. As described above, Obama's supposed status as a "crypto-Muslim" indicates possible links between his apocalyptic role and the Islamic religious tradition. Such connections between Islam and Christian eschatological scenarios are hardly new. The Middle Ages saw critical developments in the apocalyptic significance attributed to Muslims, including links between Antichrist and Muhammad, commonly presented in medieval Latin sources presented as a "false prophet" who produced Islam by perverting Christian truth through his heretical teachings.

Early medieval Christian thinkers did not tie Islam into the apocalyptic imagination as readily or quickly as one might imagine [15]. The so-called Pseudo-Methodius, a product of Syrian Christian circles dating from the later seventh but attributed to the fourth century "prophesied" the Islamic conquests of the Middle East and northern Africa, predicting that the devastation wrought by these "sons of Ishmael" prefigured the end-times ([34]; partial translation in [21], pp. 70-76). In various forms and Latin translations, this text became extremely popular in medieval Europe. Adso, however, who was probably familiar with some version of the Pseudo-Methodian tradition, made no references to Islam in his tract on Antichrist. In fact, Christians' apocalyptic associations of Islam with end-times tribulations did not really emerge until the twelfth and thirteenth centuries, a development no doubt spurred by the crusades. Particular interest in Muhammad as a sort of debased prophet and Christian heretic surged during this period, as seen for example in Guibert of Nogent's chronicle of the First Crusade, which includes a detailed account of Muhammad's origins as a sensual deceiver. One finds similar presentations of Muhammad embedded in Matthew Paris's thirteenth century world chronicle, which presents Muhammad as a libidinous charlatan [35].

For the most part, however, the apocalyptic role assigned to Islam remained one of external enemy, an apocalyptic agent that would openly attack Christendom rather than try to convert or seduce it. In the works of Abbot Joachim of Fiore, Muhammad figures as one of many Antichrists in a long-tradition of persecution. This view of Antichrist can be seen at a glance in the so-called Book of Figures, attributed to the abbot or one his immediate devotees, featuring among other images a representation of the seven-headed dragon from the Book of Revelation ([36], table 10). The seven heads are commonly presented as Herod, Nero, Constans, Muhammad, Mesomethus (another Muslim ruler, probably in Spain), and Saladin, the Muslim leader who recaptured Jerusalem from crusader-Christian hands in 1187 (an event that happened in Joachim's own lifetime). The prominence attributed to Muslim figures in this scenario is remarkable. Nevertheless, for the most part, Joachim and his many admirers did not attribute subversive role to Islam as the source of the final Antichrist, who would - as noted above-be a Christian.

Generally speaking, in contemporary American apocalyptic thought Islam continues to offer an external threat to Christianity/Western Civilization. Its significance in this regard has increased in recent decades after the collapse of the Soviet Union, which - in The Late Great Planet Earth, for example - typically played the central role in triggering the end-times political conflagration ([23], pp. 59-71). The events of $9 / 11$ and increased visibility of al-Queda (which offers its own apocalyptic scenarios involving the defeat of the United States as a force of evil in the world) have further contributed to the notion that Muslim powers such as Iran might play a key role in the end 
of things by attacking Israel ([27], pp. 326-35). Joachim of Fiore, it is worth noting, did allow for a subversive connection between Muslims outside of Christendom and heretics within it, an unholy alliance for the destruction of the faithful. In this regard, Obama's suggested status as a secret Muslim and Antichrist is not without precedent. Nevertheless, in terms of an (anti)charismatic role for Antichrist, Islam largely remains a direct threat rather than a source of prophetic inspiration that might lead the faithful astray.

\section{Antichrist and World Governance}

Although it is argued here that Antichrist represents an individual, (anti)charismatic figure of inspired but diabolic end-times leadership, his reign as featured in medieval and modern apocalyptic scenarios will not be confined to the personal exercise of his deceptive powers. Rather, Antichrist will expand and exercise his rule through governing institutions. As Gary Dickson suggests in his introductory essay to this present volume, Weber allowed room for a certain level of charisma contained in offices; he also raised the possibility of particular ways that charisma might play out in economic terms. It might be a stretch to refer to the "routinization" of (anti)charisma, thereby invoking Weber's contention that the fluid, inspired, and personal nature of charismatic leadership transforms into stable, bureaucratic, and impersonal kinds of authority. The fact remains, however, that projections of Antichrist as an inverted vision of Christ's prophetic ministry involve the claim that Antichrist will quickly_remember, his time frame for apocalyptic agency typically runs three-and-a-half or seven years - route his personal magnetism through universal organs of government and economics.

\subsection{The (Anti)Charismatic Office}

In early Christian and medieval apocalyptic scenarios, the impact of Antichrist's individual, (anti)charismatic authority will not remained limited to those in his immediate orbit. Instead, Antichrist will quickly "universalize" his mission of deception and open persecution against the faithful. As Adso of Montier-en-Der put it in the tenth century, "First, he will convert kings and princes, then others, dispatching his preachers and envoys throughout the entire world," with the result that his power will stretch from "sea to sea, from east to west, from north to south" ([20], p. 24). Over the following centuries, Latin apocalyptic thinkers contributed important innovations to the idea of Antichrist as an imperial or papal figure, occupying what in theory represented the two most elevated offices in Christian society. Much of this development occurred in response to the ongoing struggle between emperors and popes for a position of supreme authority over Christian society. From the initial contest between Emperor Henry IV (r. 1084-1106) and Pope Gregory VII (r. 1073-1084) over the investiture of bishops with the symbols of their office to the bitter warfare between Emperor Frederick II (r. 1212-1250) and Pope Innocent IV (r. 1243-1254), partisans on both sides began to slander their opponents as representatives or members of Antichrist's evil [37,38]. In apocalyptic terms, Frederick II represented something like the Barack Obama of the thirteenth century: a powerful political leader seen by some as a compelling, messianic figure and by others as Antichrist himself. 
During the thirteenth and fourteenth centuries, those who drew inspiration from the apocalypticism of Joachim of Fiore, so-called "Joachites," made some additional contributions to the association of the papacy with the reign of Antichrist. This belief emerged in part due to a controversy in the Franciscan order over the role of poverty in the Franciscan way of life, leading some "rigorist" or "spiritual" members of the order to reject papal authority when Rome opposed their cause. For one Joachite thinker, the Franciscan Peter John Olivi (1248-1298), the present-day Roman Church represented a new Babylon and source of persecution against the true Christian faithful (consisting largely of rigorist Franciscans). Olivi declared that there would be two Antichrists at the approaching end of time, a "mystical" and "great" Antichrist. That future "mystical Antichrist" would be pope, working in an evil alliance with the great Antichrist, who would be the Roman emperor ([32], pp. 207-12). In the early 1300s, the controversial papacy of Boniface VIII - no friend to the Spiritual Franciscans - added fuel to this fire, elevating the association of the papacy with Antichrist to new levels. The late medieval association of the Roman papacy with Antichrist endured as one of the more popular apocalyptic ideas of the early modern and modern eras, heightened by the Protestant Reformation and general Protestant associations of Rome with the "whore" of Babylon from Revelation ([7], pp. 200-30).

In modern apocalyptic scenarios, this projection of Antichrist's power and influence plays an especially prominent role, as the Son of Perdition's magnetism enables him to effectively co-opt major global institutions. As noted above, numbering among such official conduits for Antichrist's reign will be the World Bank, the United Nations, and the European Union. In recent years, as seen in Midnight Call, the European Union has become the prime suspect for the "reborn" Roman Empire, starting with its origins in the ten-nation European Common Market. One video posted on Youtube titled "The First Horseman of the Apocalypse-the EU \& Antichrist," traces for viewers links between Daniel's prophecies, the sack of Jerusalem by the Romans in 70CE, and the reemergence of the Roman Empire-sleeping, not dead - in the guise of European Union. Caesar's throne, the video declares, has been moved to Strasburg, site of the European Union parliament building that was built in 1998 (multiply $666 \times 3$, the video explains, and the sum = 1998). An aerial view of the structure reveals its shape like a bow and a crown, two objects associated with the first horseman of the Apocalypse (Rev. 6:2). Not coincidently, the parliament building also resembles the Tower of Babel. Through such number-crunching and visual "evidence," the association of the European Union and the end of days seems clear, setting the stage for the arrival of Antichrist [39].

\subsection{The (Anti)Charismatic Economy}

Medieval apocalyptic thinkers, naturally, were not quite as attuned to economic forces as modern ones might be, the latter responding to the rise of global capitalism as they develop their eschatological speculations. Nevertheless, premodern Christian apocalypticism contributed key elements to an imagined future wherein the (anti)charismatic forces of Antichrist's evil will shape fundamental characteristics of economic life for all people. Based on a passage in the Book of Revelation (Rev. 13:16-18), the Son of Perdition will attempt to enforce what we would now call commercial monopoly: 
And he shall make all, both little and great, rich and poor, freemen and bondmen, to have a character in their right hand, or on their foreheads, that no man might buy or sell, but he that has the character, or the name of the beast, or the number of his name. Here is wisdom. He that has understanding, let him count the number of the beast. For it is the number of a man: and the number of him is six hundred sixty-six.

As early as the second and third centuries, Christian exegetes such as Hippolytus further explained that Antichrist will erect "incense-pans" for making pagan sacrifices everywhere, and that any who refused to sacrifice will be barred from buying and selling ([17], p. 29). In the regard, the (anti)charismatic economy of Antichrist reinforces his mission to undermine Christianity and install new forms of world-wide worship.

This so-called number of the beast remains a popular fixture in the contemporary American apocalyptic imagination. In The Late Great Planet Earth, Lindsay notes that this "economic vise" was already being put in place: "In our computerized society, where we are all 'numbered' from birth to death, it seems completely plausible that some day in the near future the numbers racket will consolidate and we will have just one number for all of our business, money, and credit transactions" ([23], p. 113). Since the first publication of Linsday's book in 1970, the creation of the euro and overall intensification of global capitalism have only served to heighten this strain of apocalyptic thinking about the creation of an economic "world system" that will serve the evil ends of Antichrist, reinforcing his personal (anti)charismatic appeal and control of political organs such as the UN or EU.

Financial crisis, not just expansion, can also be interpreted as part of such schemes. According to a February 2012 piece on the Midnight Call website by Wilfred Hahn, listed as an investment banker who writes the "Money Ends and Trends" column, the current financial crisis in the euro-zone calls for a rethinking of recent apocalyptic speculation about the European Union [40]. The economic meltdown, the author points out, has centered on Greece- the tenth nation to join the European Common Market in 1981, an event which at the time led to the reasonable assumption that the international coalition represented the "ten kingdoms" predicted by Daniel. Soon, however, Spain and Portugal joined pushing membership up to twelve. At present the European Union numbers 27 members. From this perspective, Hahn declares, one might assume that the European Union must give way to a new alliance of ten "Roman" nations, which might not even be in Europe but could include other inheritor countries of the Roman tradition like Canada or the United States. The European financial crisis that started in 2008 might therefore signal the collapse of the euro-zone and European Union, opening the door to such a new configuration. As Hahn puts it, "We are today witnessing the birth pangs that will lead to the emergence of this last 10-king global power coalition."

\section{Conclusion: Apocalyptic Heroes and the End of Charisma/(Anti)Charisma}

It has been argued here that the figure of Antichrist, an eschatological projection of Christianity's false messiah, embodies a form of (anti)charisma in the Weberian mode: an inversion of all the qualities that make Christ a classic example of individual charisma as formulated by Weber. The (anti)charismatic energies embodied by the Son of Perdition, moreover, do not stop at his individual person, but spread outward to permeate the hierarchy of governing and 
economic bodies. At a rapid pace, given the compressed time-span for his reign, Antichrist's mission of perdition will subsume the world. Yet the point of such Christian apocalyptic scenarios is not despair, but hope, or at least, a healthy dose of despair leavened by hope. This present essay is hardly the place to explore Christian millennial expectations, alluded to at various points above, in which apocalyptic suffering opens the door to an earthly era of peace and justice before a final flair up of apocalyptic evil and Final Judgment. Even during the expected times of apocalyptic crisis however, God will not completely abandon the elect. As indicated in the Book of Revelation, the Lord will send his two prophets, Enoch and Elijah, to provide solace and spiritual leadership for the faithful for three-and-a-half years before Antichrist slays them (Rev. 11:3). The role of these two end-times prophets remained a staple of early Christian and medieval apocalypticism, providing a charismatic counter-point to Antichrist's (anti)charisma ([7], p. 61).

Medieval thinkers fashioned additional apocalyptic heroes and messianic figures. One of the most important in this regard was the so-called Last World Emperor, a concept that first emerged in Pseudo-Methodius and certain "Sibylline" prophecies, late antique texts attributed to earlier pagan prophets. According to this tradition, before the trials of the end-times, a new Roman emperor will arise, who will unite God's people, defeat the enemies of the Church (including, in many versions, Islam), and spread Christianity among all peoples. Having created world peace, he will go to Jerusalem and surrender his crown, setting the stage for the coming of Antichrist ([32], pp. 17-18). As noted above, thirteenth- and fourteenth-century Joachite apocalyptic thinkers contributed to lasting associations of the Roman papacy with the evils of Antichrist. They also helped to create, however, the notion of the "Angelic Pope," a coming pontiff who will succor the faithful during the end-times and help to usher in the millennial Sabbath age. This idea of the Angelic Pope would prove remarkably durable throughout the Later Middle Ages, a way of critiquing the papacy while holding out hope for its future reform and spiritual renewal [41].

Unlike their medieval counterparts, modern Christian apocalyptic thinkers seem disinterested in eschatological heroes, charismatic figures who will help to alleviate the suffering of the faithful and provide leadership during the end-times. Indeed, the prominence of the Rapture in dispensationalist scenarios - the belief that God will lift up the elect into the heavens before the seven-year reign of Antichrist - means that true believers might not even have to face the suffering of the end-times ([23], pp. 135-45). Perhaps for American Protestants such roles assigned to saints smack too much of Catholicism and detract from the ultimate place of Jesus as Redeemer before, during, and after Last Judgment. In this regard, Christ stands alone as the apocalyptic hero who will come and save those "left behind" (that is, the un-Raptured who are still deserving of redemption), defeating the Son of Perdition, ushering in the millennial age, and allowing all of the faithful to enjoy an era of peace and justice on earth. Even if Antichrist and Satan succeed in one final challenge against God after the millennium, their end is a foregone conclusion. Medieval and modern presentations of Antichrist certainly share one thing in common: his (anti)charismatic authority might be vivid, captivating, and compelling, but it is doomed to failure. Antichrist's parody of Christ's life and charismatic appeal can only go so far. With Christ's Second Coming, moreover, the Son of God no longer represents a prophetic figure, the charismatic God-man; he is transcendent, coming to judge the living and the dead. Ultimately, both (anti)charisma and charisma imagined as Weberian 
categories will no longer serve any purpose, as history reaches its apocalyptic conclusion and yields to the timeless kingdom of God.

\section{Acknowledgments}

I would like to thank Gary Dickson for his editorial support and encouragement.

\section{References and Notes}

1. Jackson Williams. "Texas Megachurch Pastor: 'Obama Paving the Way for Future reign of Antichrist." Huffington Post, 6 November 2012. http://www.huffingtonpost.com/jacksonwilliams/robert-jeffress-obama-antichrist_b_2084303.html.

2. Amy Hollyfield. "Complete Distortion of the Bible." Politifact.com, 2 April 20008. http://www.politifact.com/truth-o-meter/statements/2008/apr/02/chain-email/completedistortion-of-the-bible/.

3. "Is Barack Obama the Antichrist." Pt. 1, Available online: http://www.youtube.com/watch? $\mathrm{v}=\mathrm{oRP} 3 \mathrm{kAASxVo \& bpctr}=1353337562$. Pt. 2, Available online: http:/www.youtube.com/ watch? $\mathrm{v}=\mathrm{cL} 871 \mathrm{CVn} 4 \mathrm{~T}$ A\&feature $=$ relmfu (accessed on 19 November 2012).

4. "The Antichrist is Barack Obama." Available online: http://www.youtube.com/ watch? $\mathrm{v}=\mathrm{v} 80 \mathrm{dw} x \mathrm{t} 8 \mathrm{t}-\mathrm{c}$ (accessed on 19 November 2012).

5. S.N. Einsenstadt, ed. Max Weber on Charisma and Institution Building: Select Papers. Chicago: University of Chicago Press, 1968.

6. Max Weber. The Sociology of Religion. Translated by Ephraim Fischoff. Boston: Beacon Press, 1963.

7. Bernard McGinn. Antichrist: Two Thousand Years of the Human Fascination with Evil. New York: Columbia University Press, 2000.

8. Video posted on Real Clear Politics. Available online: http://www.realclearpolitics.com/ video/201 1/09/26/heckler_calls_obama_the_antichrist_at_la_fundraiser.html (accessed on 19 November 2012).

9. Kate Zernike. "The Charisma Mandate." New York Times, 17 February 2008. http:// www.nytimes.com/2008/02/17/weekinreview/17zernike.html?pagewanted=1\&_r=3\&ref=us.

10. "Is Obama the Messiah." Available online: http://obamamessiah.blogspot.com/ (accessed on 19 November 2012).

11. Joanna Zelman. "Mitt Romney Slams Obama on Climate Change in Convention Speech." Huffington Post (with video clip of segment), 8 August 2012. http://www.huffingtonpost.com/ 2012/08/31/mitt-romney-obama-climate-change_n_1846440.html (accessed on 1 December 2012).

12. Video clip posted on Youtube. Available online: http://www.youtube.com/ watch? v=vws9fTtQgz4 (accessed on 1 December 2012).

13. Robert Markus. Saeculum: History and Society in the Theology of St Augustine. Cambridge: Cambridge University Press, 1989.

14. Paula Fredriksen. "Tyconius and Augustine on the Apocalypse." In The Apocalypse in the Middle Ages. Edited by Richard K. Emmerson and Bernard McGinn. Ithaca: Cornall University Press, 1992, 20-37. 
15. Jean Flori. L'Islam et la fin des temps: l'interprétation prophétique des invasions Musulmanes dans la chrétienté médiévale. Paris: Seuil, 2007.

16. Irenaeus. "Against Heresies." In Ante-Nicene Christian Library, vol. 9, The Writings of Irenaeus, vol. 2. Edited by Alexander Roberts and James Donaldson. Edinburgh: T. and T. Clark, 1869, 1-57.

17. Hippolytus. "Christ and Antichrist." In Ante-Nicene Christian Library, vol. 9, The Writings of Hippolytus, Bishop of Portus, vol. 2. Edited by Alexander Roberts and James Donaldson. Edinburgh: T. and T. Clark, 1869, 3-40.

18. Robert Lerner. "Refreshment of the Saints: The Time after Antichrist as a Station for Earthly Progress in Medieval Thought." Traditio 32 (1976): 97-144.

19. Kevin Hughes. Constructing Antichrist: Paul, Biblical Commentary, and the Development of Doctrine in the Early Middle Ages. Washington: Catholic University of America Press, 2005.

20. Adso Montier-en-Der. De ortu et tempore Antichristi. Edited by Daniel Verhelst. Corpus Christianorum Continuatio Medaevalis, 45. Turnholt: Brepols, 1976;

21. Bernard McGinn. Visions of the End: Apocalyptic Traditions in the Middle Ages. New York: Columbia University Press, 1998.

22. Richard K. Emmerson. "Antichrist as Anti-Saint: The Significance of Abbot Adso's Libellus de Antichristo." American Benedictine Review 30 (1979): 75-90.

23. Hal Lindsey. The Late Great Planet Earth. Grand Rapids, Mich.: Zondervan Publishing, 1970.

24. Ben Smith. "Culture of Conspiracy: The Birthers." Politico, 1 March 2009. http://dyn.poli tico.com/printstory.cfm?uuid=BF547975-18FE-70B2-A85A7CB6F7889EED.

25. Werner Goez. Translatio imperii: ein Betrag zur Geschichte des Geschichtsdenkens und der Politischen Theorien im Mittelalter und in der frühen Neuzeit. Tübingen: Mohr, 1958.

26. Midnight Call - The International Voice of Prophecy. Homepage: http://www.midnightcall.com/ (accessed on 1 December 2012).

27. Paul Boyer. "The Middle East in Modern American Popular Prophetic Belief." In Imagining the End: Visions of Apocalypse from the Ancient Middle East to Modern America. Edited by Abbas Amanat and Magnus Bernhardsson. London: I. B. Tauris, 2001, 312-25.

28. Robert Lerner. The Feast of St. Abraham: Medieval Millenarians and the Jews. Philadelphia: University of Pennsylvania Press, 2002.

29. Anna S. Abulafia. "The Conquest of Jerusalem: Joachim of Fiore and the Jews." In The Experience of Crusading. Edited by Marcus Bull and Norman Housely. Cambridge: Cambridge University Press, 2003, 127-46.

30. E. Randolph Daniel. "Abbot Joachim of Fiore and the Conversion of the Jews." In Friars and Jews in the Middle Ages and Renaissance. Edited by Steven J. McMichael and Susan E. Myers. Leiden: Brill, 2004, 1-22.

31. Brett E. Whalen. "Joachim of Fiore, Apocalyptic Conversion, and the "Persecuting Society." History Compass 8 (2010): 682-91.

32. Brett E. Whalen. Dominion of God: Christendom and Apocalypse in the Middle Ages. Cambridge, MA: Harvard University press, 2009.

33. Robert Lerner. "Antichrists and Antichrist in Joachim of Fiore." Speculum 60 (1985): 553-70. 
34. J. A. Aerts and G.A.A. Kortekaas, ds. Die Apokalypse des Pseudo-Methodius: Die ältesten griechischen und lateinischen Übersetzungen. Corpus Scriptorum Christianorum Orientalium, 570 (Subsidia 98). Louvain: Peeters, 1998; see also Apocalypse Pseudo-Methodius: An Alexandrian World Chronicle. Edited and translated by B. Garstad. Cambridge, MA: Harvard University Press, 2012.

35. John Tolan. Saracens: Islam in the Medieval European Imagination. New York: Columbia, 2002.

36. Leone Tondelli, eds. Il libro delle figure dell'abate Gioachino da Fiore. Turin: Società editrice internazionale, 1953.

37. Bernard McGinn. "Apocalypticism and Church Reform: 1100-1500.” In The Encyclopedia of Apocalypticism: Apocalypticism in Western History and Culture. Edited by Bernard McGinn. New York: Continuum, 1998, 74-109.

38. Robert Lerner. "Frederick II, Alive, Aloft and Allayed, in Franciscan-Joachite Eschatology." In The Use and Abuse of Eschatology in the Middle Ages. Edited by Werner Verbeke, Daniel Verhelst and Andries Welkenhuysen. Leuven: Leuven University Press, 1988, 137-211.

39. "The First Horseman of the Apocalypse - the EU \& Antichrist." Available online: http://www.youtube.c om/watch?v=dU8GF-r1TcE (accessed on 1 December 2012).

40. Wilfred Hahn. "Greek Tragedy of the Revived Roman Empire featured." Midnight Call, 1 February 2012. http://www.midnightcall.com/articles/moneyends-a-trends/item/1694-greatgreek-tragedy-of-the-revived-roman-empire.

41. Bernard McGinn. "Angel Pope and Papal Antichrist." Church History 47 (1978): 155-73. 
Reprinted from Religions. Cite as: Aird, W.M. "Saint Anselm of Canterbury and Charismatic Authority." Religions 5 (2014): 90-108.

\title{
Saint Anselm of Canterbury and Charismatic Authority
}

\author{
William M. Aird
}

\begin{abstract}
The early career of Archbishop Anselm of Canterbury (c. 1033-1109) provides an opportunity to explore the operation of charismatic authority in a monastic setting. It is argued that the choice of Anselm for the archiepiscopal see of Canterbury in 1093 was the result of his growing reputation cultivated during his years as prior and abbot of the influential Norman monastery of Bec. The article explores various aspects of Anselm's charismatic authority including his performance of charisma, the charisma derived from his fame as a scholar, and his reputation as a miracle-working holy man.
\end{abstract}

\section{Introduction}

The election of Anselm (c. 1033-1109), abbot of the monastery of Bec in Normandy, to the archbishopric of Canterbury in the spring of 1093 was a violent affair ([1], pp. 49-71). According to contemporary sources, the majority of which were generated either by Anselm himself, members of his entourage or other later writers sympathetic to him, the abbot of Bec was in England on his monastery's business and had arrived at the royal court in Gloucester to find the king, William Rufus (ruled 1087-1100), son of William the Conqueror (ruled 1066-1087), dangerously ill. It was thought that Rufus was about to die and the members of his court advised him to make his peace with God by releasing all prisoners, remitting fines, and freeing those churches whose revenues he had kept in his own hands after their incumbents had died. Above all he was urged to appoint an archbishop to Canterbury for, they said, '[t]he oppression of that Church is nothing less than the destruction of all Christianity in England, a thing most hateful' ([2], pp. 31-32). Anselm was summoned to the king's bedside and he too counselled Rufus to prepare his soul for its encounter with the Almighty. Anselm received the king's confession and witnessed his pledge that he would make amends for the wrongs he had committed. The promise was written out and verified with the king's seal. Rufus agreed to release prisoners, remit fines, pardon all offences, and provide his people with good and righteous laws. At this there was great jubilation and fervent prayers were offered for the recovery of 'so good, so great a king' ([2], p. 32). Finally, Rufus was urged to appoint an archbishop for Canterbury and he readily agreed to do so because, so he said, he had already been thinking of so doing. But who should be appointed? The king 'of his own accord' declared that the best man for the job was the abbot of Bec. At this Anselm 'turned deathly pale' with shock at the suggestion ([2], p. 32). 
Anselm protested that he did not want the office and he tried to resist 'with all his might'. The bishops present, who had probably invested much in their advocacy of Anselm, took him to one side and remonstrated with him, pointing out that the English Church was in a state of crisis:

'You see,' they said, 'that all Christianity in England has nearly died out, all has fallen into confusion; abominations of every kind have arisen on all sides, that we ourselves and the Churches of God, which we should rule have fallen into peril of eternal death through the tyranny of this man and do you then, when you could help, not deign to do so? What are you thinking of, you extraordinary man? Where are your wits? [Quid O mirabilis homo cogitas? Quo fugit sensus tuus?] The Church of Canterbury, whose oppression is the oppression and ruin of us all, calls you, in her troubles implores you, to be her deliverer and ours; and do you, with little regard for her liberty, little regard too for our deliverance, refuse to share the labours of your brethren and care only for your own selfish ease and repose?'

Anselm admitted that there were indeed grave problems, but he pleaded that he was old and 'unfit for worldly work' ([2], pp. 32-33; [3], pp. 33-34). The abbot of Bec protested vehemently that he should not be appointed to Canterbury but the bishops dragged him to the king's beside. Rufus, almost in tears, pleaded with Anselm to remember the friendship he had shown towards his parents and not let him die still holding the archbishopric of Canterbury for fear that this would condemn his soul to torment. Still Anselm refused. Those surrounding the king became angry and accused the abbot of Bec of abandoning a dying man and condemning England to future oppressions. Turning to two of his followers, the monks Baldwin and Eustace, Anselm asked their advice. In tears, Baldwin answered that if it was the will of God, Anselm should obey and at that moment Baldwin's nose began to bleed ([2], pp. 33-34). The king instructed all those present to kneel at Anselm's feet in a gesture of supplication, but Anselm also kneeled down and still refused. Finally, the crowd shouted for the pastoral staff to be brought and they bent back Anselm's fingers when he closed his fist to resist their attempts to force it into his hands. The bishops held the staff against his fist and then he was carried off into a neighbouring church still loudly protesting his objections. He cried out:

'Do you realize what you are trying so hard to do? You are trying to harness together at the plough under one yoke an untamed bull and an old and feeble sheep. And what will come of it? Why, without doubt the untameable fury of the bull will drag the sheep, which should produce wool and milk and lambs, this way and that through the thorns and the briars; and the bull, if it do not shake itself of the yoke altogether, will so tear the sheep that the sheep, unable to furnish any of these good things, will be of no use either to itself or anyone else. How so? You have thoughtlessly mated the sheep with the bull. [Quid ita? Inconsiderate ovem tauro copulastis.]' ([2], pp. 35-36; [3], pp. 35-36).

Anselm continued the metaphor to explain that the Church in England was a plough and that it should be pulled along by two equally matched oxen, namely the king and the archbishop of Canterbury, the one drawing the plough along by his human justice and sovereignty, the other by divine doctrine and authority ([4], pp. 29-45). What Anselm feared was that the young king's 'untameable fury' would eventually destroy the feeble old sheep ([2], p. 36).

Anselm's dramatic 'election' as archbishop of Canterbury in 1093 marked the beginning of his turbulent relationships with successive kings of England, William Rufus and his younger brother Henry I (ruled 1100-1135), ([1], pp. 73-99; 125-66). In each case, Anselm felt obliged to go into 
exile, thereby abandoning his church to the depredations of the royal officers. Anselm's election has been the subject of much debate and, from the late eleventh century onwards, questions have been raised as to the sincerity of Anselm's opposition to his appointment. Soon after his elevation to the archdiocese of Canterbury, he felt it necessary to write to the monks of Bec giving his version of events as there were evidently rumours circulating that he had, in fact, wished for the appointment to the archiepiscopal see ([5], Volume IV, pp. 3-6; [6], Volume II, No. 148, pp. 7-11). An examination of Anselm's career from his birth around 1033 in Aosta, now in Northern Italy, to the dramatic events of his election in April 1093, provides an opportunity to explore Anselm's rise to prominence and whether using Weber's model of charismatic authority can aid an interpretation of these events. Anselm's monastic career also raises questions about the place of charisma in the monastery and the role it played in the creation and maintenance of abbatial authority. Given Anselm's fame as an intellectual by 1093, the notion of academic charisma, understood in this context as the social capital and influence he derived from his reputation as a teacher, theologian and philosopher, might also be relevant here ([7], pp. 3-30). It is worth noting at the outset that the medieval sources for Anselm's life and career display considerable bias in his favour and suggest that Anselm and his followers were careful to manage his public reputation. In addition, from Anselm's own day forward, the conventions of medieval hagiography have influenced and continue to influence representations of the Archbishop [8,9]. These issues concerning the sources for a study of Anselm are addressed below.

\section{Anselm and Charisma}

By the spring of 1093, Abbot Anselm of Bec enjoyed a considerable reputation and this influenced those who chose him as the new archbishop for Canterbury, a position vacant since the death of Lanfranc in May 1089 ([10], p. 225). Since 1078 he had been the abbot of Bec, arguably the most influential monastery in Normandy ([1], pp. 23-48). He had served as prior under the monastery's founder, the charismatic Abbot Herluin, before being elected unanimously by the monks of Bec as abbot ([11], pp. 15-25; [12], pp. 12, 44). When Anselm entered the monastery its affairs were in the hands of another influential figure, Prior Lanfranc, who later served as abbot of the Conqueror's abbey of Saint-Étienne, Caen, before being appointed, in 1070, to the archdiocese of Canterbury ([10], pp. 11-74). Lanfranc was also a man of European reputation and his pontificate at Canterbury witnessed a period of considerable change in the post-Conquest English Church ([10], pp. 78-174). Lanfranc was Anselm's mentor, or perhaps it is more appropriate to say that Anselm was Lanfranc's disciple or follower. Even after his departure for Caen and Canterbury, Lanfranc exercised considerable influence over Anselm ([10], pp. 21-22, 150-51, 175-76, 180-81, 208-13; [13], pp. 39-66). Abbot Herluin and Prior Lanfranc represented contrasting but equally charismatic models for Anselm to emulate as he embarked on his monastic career.

The aim of this paper is to explore whether Anselm possessed the kind of charismatic authority that Weber envisaged in his analysis of the three forms of authority that underpin his theory of legitimate domination ([14], pp. 106-36). Anselm's modern biographer, R.W. Southern, refers to the 'remarkable hold that he [Anselm] had on the affection of violent and aggressive magnates', and to his 'extraordinary power of winning the love of people of all kinds', but the word 'charisma' is not indexed in his study ([13], pp. 182, 184). As Weber originally borrowed the term from 
religious - indeed monastic - history and the work of Rudolf Sohm, it seems appropriate to apply it to the career of one of the most prominent ecclesiastical figures of the eleventh century ([15], p. 328; [16], p. 764 and n. 3; [17], pp. 185-97). Can the concepts of charisma and charismatic authority assist an analysis of Anselm's rise to prominence, and his role as abbot of Bec, as well as providing another perspective on the circumstances of his appointment to Canterbury? It should be noted that Weber reinterpreted the original Pauline conception of charisma. As delineated in Paul's Epistles to the Romans and to the Corinthians, the charismata did not include the divine gift of leadership and authority. It has been suggested that Paul's aim was to emphasize that these spiritual gifts were to be understood in communal terms, as binding together early Christian congregations, rather than creating or reinforcing hierarchies ([14], pp. 23-50). For Weber, however, charisma was understood as an almost mystical component of the heroic leader's authority allowing him to emancipate his peers from the heavily impersonal traditional and rational forms of social authority ([18], Volume II, pp. 1111-57; [14], pp. 106-36). It is thus Weber's construction of aspects of charismatic authority that informs the following discussion.

Anselm's individual, personal charisma preceded and influenced his election to a series of offices within the monastery at Bec, before assuring that he was nominated for the vacant archiepiscopal chair at Canterbury. It will be argued that the sources, tinged as they are with shades of hagiographical convention, do indeed indicate that Anselm exhibited certain traits of charismatic authority, but that these operated in conjunction with other forms of authority found in medieval monastic communities. It will also be suggested that Anselm was careful to cultivate a public image or reputation, partly based on his devotional, theological and philosophical writings, and partly on his status as abbot of Bec, which enabled him to make the most of those divine charismata or gifts with which his followers believed he was endowed. In this respect, the appointment to Canterbury may be seen as the culmination of a process of honing those gifts and it cannot be said, pace Weber, that, like other charismatic leaders, he sprang from nowhere to defy traditional authority through offering charismatic leadership ([18], Volume II, p. 1123). The paper concludes with a brief discussion of the dissolution of Anselm's charismatic authority, at least as far as the kingdom of England is concerned, after 1097 once his followers realised that he could not — or would not — offer the leadership that they had expected at his elevation to Canterbury. The troubles Anselm experienced on his return to England from exile in the early years of Henry I may in part be attributable to the dissolution of his charisma in the preceding reign. However, it is necessary to begin by considering the nature of the main sources for such a study. 


\section{Biographer and Subject: Eadmer of Canterbury and Anselm of Bec}

The main sources for Anselm's career are Anselm's own writings, especially his collected letters, and the accounts compiled by his disciple, Eadmer, monk of Canterbury, which contain a great deal of information derived from Anselm himself $[2,5,12]$. Eadmer was perhaps thirty years Anselm's junior when he first met his hero in 1079. Eadmer was probably from a Kentish family and was born around 1060 ([13], pp. 402-21; [19], pp. 229-40; [20], pp. xiii-xxxv). He tells us that he was brought up in the cathedral priory of Christ Church Canterbury, which suggests that he entered the monastery as an oblate that is as child to be educated in the monastic life. In his writings, Eadmer refers to events he witnessed in the pontificate of Archbishop Lanfranc (1070 to 1089), but it was the meeting with Anselm and their subsequent relationship which had the most profound effect on his life ([12], I. xxix, pp. 48-50). Eadmer produced two linked accounts of Anselm's career based on notes he had been compiling during his time with the archbishop [2,12,21,22]. Perhaps around 1100, Anselm asked to see these writings and, at first, corrected and rearranged the materials he was given. A little afterwards Anselm changed his mind and, arguing that he was not worthy of a literary memorial, ordered Eadmer to destroy the texts. Eadmer obeyed his master's command but also managed to preserve the material by perpetrating an act of pious disobedience. 'So I observed the letter of his command,' he tells us, 'and destroyed those quires, having first copied their contents onto other quires. Perhaps my action was not free from the sin of disobedience, for I carried out his order otherwise than I knew that he intended' ([12], II. lxxii, pp. 150-51). Anselm's decision to forbid Eadmer's work may have been an expression of his humility, or an attempt to control the production of texts that might affect his work and public image. That Anselm was sensitive to such issues is suggested by the fact that in the Preface to his treatise Cur Deus Homo, Anselm noted that ' $[\mathrm{b}]$ ecause of some people who, without my knowledge, began copying out the first parts of this work before it was finished and fully researched, I have been compelled to complete the work that follows, to the best of my ability, in greater haste than would have been opportune from my point of view' ([5], Volume II, p. 42; [23], p. 261). The first version of the Vita S. Anselmi has been dated to between 1112 and 1114 ([20], p. xxiii). Its companion, Eadmer's Historia Novorum in Anglia, it has been argued, originally ended with Anselm's death in 1109, but he added further material ([20], pp. xxiii-ix). These two works form the basis for any study of Anselm's life, but, as has been noted, they can be supplemented by his letter collection and other contemporary or near-contemporary accounts of his career (e.g., [24]).

Eadmer's view of Anselm is that of a disciple and biographer and the fact that Anselm, at least as far as Eadmer was concerned, was a living saint should be borne in mind when assessing the evidence presented here ([25], pp. 8-9). Biographers run the risk of identifying themselves too closely with the concerns of their subjects and falling into the temptation of defending their actions at every turn. Eadmer was also a hagiographer and his expectations of the holy men he wrote about may have coloured his portrayal of Anselm and enhanced his sense of his subject's charisma ([20], pp. xiii-xxxv; [8], pp. 38-71; [25], pp. 29-48). As a fellow monk, younger contemporary, and disciple, Eadmer shared almost the same normative and moral outlook as his subject, namely that of the Rule of St Benedict [26]. It might be assumed that he understood Anselm in ways that the modern historian cannot, no matter how much empathic sensibility is brought to the study. Weber 
himself wondered whether it was possible to write about religious experience in rational terms at all ([27], p. 233; [28], p. 23; cf. [29], pp. 1-30). There are signs, however, that Eadmer was not an unquestioning devotee of Anselm and the story of his pious disobedience suggests that he had the self-confidence to defy his hero, especially when his own interests as a writer were threatened.

\section{Anselm Encounters Monastic Charisma}

The account of Anselm's monastic conversion provides a revealing insight into the level of his ambition. Eadmer, presumably drawing on the archbishop's own recollections, tells us that Anselm left his home in Aosta (Northern Italy) after he and his father fell out. ${ }^{1}$ It is clearly implied that the death of Anselm's mother, Ermenburga, was associated with this rift. Without her, Eadmer tells us, Anselm felt as though 'the ship of his heart had lost its anchor' ([12], I. iv, p. 6). Without her influence he may have succumbed to those worldly temptations that her presence had always dissuaded him from indulging in. Certainly, his writings, particularly his Prayers and Meditations, express an acute sense of personal sinfulness that may reflect a dissolute lifestyle in the years between the death of his mother and his monastic conversion ([5], Volume III, pp. 3-91; [31]).

Anselm headed north across the Alps and eventually arrived at Bec, drawn there by the fame of its prior, Lanfranc ([12], I. v, pp. 8-10; [10], pp. 15-24). Anselm recognised Lanfranc's 'outstanding wisdom, which shone forth in him' and he placed himself under his guidance ([12], I. v, p. 8). In other words, Anselm fell under Lanfranc's charismatic spell and became one of his followers. We are told that 'Anselm's devotion to Lanfranc was so great, and his belief in the value of Lanfranc's advice so strong, that if, while they were going to Rouen through the great wood which lies above Bec, Lanfranc had said to him "Stay in this wood and see that you never come out so long as you live", without a doubt, as he used to say, he would have obeyed that command' ([12], I. vi, p. 11). It is no surprise to learn that Anselm looked to Lanfranc for guidance as to the future path his life should take. In a revealing passage Eadmer tells us that Anselm contemplated taking monastic vows at Bec or at the famous and very influential Burgundian abbey of Cluny. However, he hesitated because he feared that he would either be overshadowed by Lanfranc's brilliance at $\mathrm{Bec}$, or that the rigorous nature of life at Cluny would also condemn him to 'fruitlessness or insignificance'. Anselm confessed to Eadmer that he recognised how shallow this made him appear, and added in his defence that 'I was not yet tamed, and there was not yet in me any strong contempt of the world' ([12], I. v, p. 9). Anselm's youthful ambition is revealing here and it was only with hindsight that he understood how self-serving it appeared. Anselm was fearful of living in obscurity, his own light put into the shade by the personal charisma of Lanfranc on the one hand, or obscured by the rigorous regime and collective charisma of the monks of Cluny on the other. He was looking, so he told Eadmer, for somewhere to display his knowledge and be of service to others. Here, Anselm seems to have articulated a sense of mission, which consisted of an uneasy combination of the desire for self-promotion and the call to serve others ([12], I. v, p. 9). Anselm's later embarrassment at this episode suggests that it was the fear of reputational obscurity

1 It is interesting to note that Weber too had an argument with his father after which he never saw him again. News of his father's death seems to have triggered a mental breakdown ([28], p. 14). For the suggestion that personal trauma is a source of charismatic motivation, see [30]. 
rather than the missed opportunity for public service that so exercised him. This combination of self-promotion and the desire to serve others so that they might benefit from the charismatic's personal gifts might be seen as typical of these figures. A charismatic leader needs followers and so obscurity was not an option for Anselm. The trope of service to others is reflected in the use of the formula servus servorum Dei ('servant of the servants of God') used by heads of medieval monastic houses, the papacy, and, indeed, by Anselm as abbot of Bec (e.g., [5], Volume III, pp. 232-34; [6], I, No. 101, pp. 252-55). The confidence in his own abilities and indeed the conviction that only he could provide answers for his followers might be indicated by Eadmer's report of his hero's demise in 1109. In his final illness, Anselm expressed a concern that, if he died, no-one else would be able to settle the question about the origin of the soul that he had been working on ([12], II. lxvi, p. 142). Anselm himself provided Eadmer with a clue as to the origins of this sense of personal mission. As a boy, Anselm had a vision in which he met and spoke with God in His heavenly court. If Anselm retained this memory for the rest of his adult life, it may have provided the foundation for the confidence in his self-worth that he repeatedly displayed ([12], I. ii, pp. 4-5).

Once he had decided, with the help of Lanfranc and Archbishop Maurilius of Rouen (1055-67), to become a monk at Bec, Anselm, then aged twenty-seven, set his mind to emulating the more religious of the monks ([12], I. vii, pp. 11-13). So successful was he that he became the very pattern of the monastic life. For three years Anselm practised his monastic vocation assiduously and, Eadmer reported, he was rewarded with the gift of insight concerning the divinity of God. One night he was so fixed on trying to understand how it was that the prophets of old 'could see both past and future as if they were present', that he seemed to acquire the ability to see through the solid walls of the church and dormitory and watch his fellow monks preparing for matins ([12], I. vii, pp. 12-13). This extraordinary faculty was the mark of the charismatic and it must be assumed that reports of Anselm's divine gifts became the subject of whispered conversation in Bec's cloister and perhaps of rumours circulating beyond the monastery walls. Recognition of Anselm's personal charismata played a role in his elevation as prior on Lanfranc's departure for Caen in 1063 and then, on the death of Herluin in 1078, as abbot, although, as has been mentioned, authority and leadership were not components of the original Pauline conception of charisma ([12], I, p. 12; I. xxvi, p. 44).

Abbot Herluin was Bec's charismatic figurehead and as he grew older he relied more and more on Anselm for the day to day running of his monastery [32,33]. In this respect, Anselm might be seen as an agent of the process Weber identified as the 'routinization of charisma' ([15], pp. 363-66). In order to deal with the necessary and mundane operations of the monastery some of Herluin's personal charismatic authority had to be combined with more traditional and legal forms of domination ([34], pp. 287-88). Herluin's deputy, the prior, ensured that discipline was maintained in the monastic community and that the everyday needs of its members were met. This raises the question of the other kinds of authority functioning within the monastery. The dominant normative monastic text in the Medieval West was the Rule of St Benedict. The Rule prescribed that the monks would obey their abbot, whose authority was derived from his office ([26], Chapter 5, pp. 14-15]. This would seem to align with Weber's characterisation of 'rational-legal' authority in which official functions are bound by rules, or, in this case the Rule ([34], p. 330). That is not to say 
that the charismatic authority of the individual abbot might not enhance the authority derived from the office exercised by those in positions of power within the medieval monastery. The abbot was also given advice on how to fulfil his role and it is instructive to compare the record of Anselm's actions with these guide-lines ([26], Chapter 2, pp. 6-9).

According to his biographer, Anselm demonstrated a talent for empathy so that he 'understood the characters of people of whatever age or sex'. It was claimed that he had the ability to open up the secrets of their hearts and to expose their propensity for virtue or vice. There was no doubt that 'the spirit of counsel ruled in his heart' ([12], I. viii, pp. 13-15; cf. [26], pp. 6-9). As well as this aspect of his charisma, Anselm began to perform the bodily discipline expected of a holy man ([12], I. viii, pp. 14-15). Anselm's charismatic authority was to some extent dependent on this performativity, an aspect that is explored further below. The medieval Church understood the power of outward manifestations of inner spirituality and the monks of Bec seem to have been especially adept in the use of holy tears. Anselm wept along with the best of them and the sincerity of his compunction was demonstrated again and again by the copious tears he shed [35]. Anselm's bodily comportment and the sheer emotional content of his spirituality as expressed most notably in his Prayers and Meditations enhanced his charismatic authority (e.g., [5], Volume III, pp. 3-91; [31]). This was necessary for Anselm had enemies within the monastery. Eadmer described the extent of the problem:

...some of the brethren of the monastery were his enemies, being envious at seeing him, whom in seniority of profession they judged ought to have come after them, preferred before them. Being thus upset, they upset others; they spread scandal, they made dissensions [scandala movent, dissentiones pariunt], they formed cliques and fostered hatreds ([12], I. ix, pp. 15-16).

If his exemplary life was not sufficient to prompt his opponents to emulate him, Anselm's solution was to find another way to reach his enemies. Here we are introduced to the 'holy guile' [quadam sancta calliditate] through which he brought his opponents round to his will. Eadmer gives the example of the monk Osbern whom Anselm trained to love him. The technique described involved at first flattering the young monk and indulging his boyish pranks, and then, after winning his trust, gradually refashioning his outlook by withdrawing the indulgences and bringing him round to conformity. That refashioning might involve corporal punishment as well as verbal admonishment. Anselm's programme had the desired effect and Osbern the rebellious monk became one of his prior's most devoted followers ([12], I. x, pp. 16-20). The ability of the charismatic leader to inspire love in his followers seems to be demonstrated in Anselm's reconfiguration of the emotions of the young monk Osbern. The application of this 'holy guile' also suggests parallels with the techniques of more modern charismatic leaders such as Jim Jones, the leader of the Peoples Temple ([36], pp. 137-55).

Anselm's educational techniques have been the subject of detailed investigation [37]. Part of Anselm's success was due to his ability to reach his followers through the use of effective rhetorical techniques. He was a master of the apt metaphor as his explanation as to why he focused his attention on the education of adolescents makes clear. Drawing his metaphor from the practice of sealing documents with wax, he noted that it was difficult to make an impression on the hardened wax of old men 'sunk in the vanity of the world'. Similarly, the molten wax of the very young who are unable to distinguish between good and evil will not hold an impression. Only the 
wax of the adolescent, lying as it does between these extremes will hold the impression one gives it. 'If you teach him, you can shape him as you wish' ([12], I. xi, pp. 20-21).

In dealing with opposition within the monastery, Anselm was able to draw on the institutional charismatic authority of his position as prior which, in a monastery such as Bec headed by a charismatic, but administratively passive abbot like Herluin, gave him considerable power. In this respect he emulated the position of his predecessor, Lanfranc, and, as has been noted, embodied that routinization of charisma that Weber envisaged as the inevitable development of charismatic authority. By the time he left Bec in 1092 to come to England, he was accustomed to his personal charisma being reinforced by the institutional charisma and authority of the monastic offices he had held.

Eadmer suggests that long before his elevation to Canterbury, Anselm, then still in Normandy, found the burdens of office wearisome and tearfully petitioned Archbishop Maurilius of Rouen that he might be relieved of his duties. The archbishop refused to countenance the request and Anselm was ordered to retain the office of prior unless his abbot decreed otherwise. In what might be a later addition or interpretation of this exchange, Eadmer wrote that Maurilius predicted that Anselm would not long remain in his current post, but would be elevated to a higher office ([12], I. xii, pp. 21-22). Part of Anselm's reported reluctance to continue as prior may have stemmed from a desire to continue his theological and philosophical writing unhindered. Anselm's growing reputation in the period before his election to the see of Canterbury was in no small measure due to the charisma derived from his reputation as a scholar, which provided an added source of authority, and so his complaints about the burden of his administrative duties may have had some force.

\section{Anselm's Scholarly Charisma}

By the time of his election as archbishop of Canterbury, Anselm had established a reputation as a theologian and philosopher. As well as his popular and widely circulated Prayers and Meditations, and early writings On Truth, On the Freedom of the Will and On the Fall of the Devil, he also developed a preoccupation with the nature of God which he explored in two influential works ([38]; [5], Volumes I-III; [23]). In his famous text the Monologion completed before 1077, his methodology departed from the usual path of monastic intellectual enquiry in that he "put aside all authority of Holy Scripture [and] enquired into and discovered by reason alone what God is, and proved by invincible reason that God's nature is what the true faith holds it to be, and that it could not be other than it is' ([12], I. xix, pp. 28-31; [5], Volume I, pp. 1-87; [23], pp. 3-81). As described by Eadmer, Anselm became obsessed with this work and could think of nothing else. Just as he began to worry that his preoccupation might be a trick of the Devil, he experienced a moment of clarity and quickly committed his thoughts to wax tablets. In the context of this discussion of Anselm's charisma, it is significant that Eadmer reports this revelation in the following manner:

Then suddenly one night during matins the grace of God illuminated his heart, the whole matter became clear to his mind, and a great joy and exultation filled his inmost being ([12], I. xix, p. 30).

Anselm's understanding was a gift from God in the original, Pauline, sense of the Apostolic charismata ([14], pp. 23-50). 
Anselm's ontological proof for the existence of God has since become famous, but his method challenged accepted practice and prompted misgivings in his mentor, Lanfranc, whose approval of an early version of the text was, as one of Anselm's modern biographers put it, 'less than lukewarm' ([12], I. xix, p. 29, n. 2; cf. [5], Volume III, pp. 193-94; [6], Volume I, No. 72, pp. 197-98). Despite his protestations that he would do nothing with the work unless it met with Lanfranc's approval, Anselm persevered with it and, together with the Proslogion, it became a major component of his reputation as a scholar. There is an interesting story preserved by Eadmer that the wax tablets used by Anselm were 'lost' and it might be the case that the monk into whose charge he committed them for safe-keeping found their contents disturbing. Another set of wax tablets were found broken the next morning ([12], I. xix, pp. 30-31). The self-confidence needed to challenge accepted practice in theological matters suggests that Anselm possessed the charismatic self-assurance, or arrogance, to challenge tradition, a trait identified by Weber as characteristic of the charismatic leader. Anselm was lauded and he was invited to preach to clergy and laity alike. He was the guest of honour in monastic houses and the residences of the aristocracy in Normandy, England, and beyond ([12], I. xxii, pp. 39-40). He talked with everyone, great and small, and even set aside time to talk to a mere youth of about nineteen (Eadmer), who would later become his biographer ([12], I. xxix, pp. 48-50; I. xxxi, pp. 54-57). Anselm's writings were criticized and he was called to defend his texts from charges of unorthodoxy (e.g., [38], p. 24). But such was Anselm's fame as a scholar that at the Council of Bari in 1098 he was chosen by his friend, Pope Urban II, to speak on behalf of Latin Christendom and refute the 'errors of the Greeks on the Procession of the Holy Spirit' ([12], II. xxxiv, pp. 112-13).

\section{Signs and Wonders}

Anselm's reputation did not rest on his intellectual achievements alone. His charismatic authority was also strengthened through the perception of his living sanctity and the working of miracles. As has been noted, as a boy, Anselm had reported to all who would listen that he had had a vision in which he met and spoke with God. He was also fed with the pure white bread of Heaven ([12], I. ii, pp. 4-5). Later, as well as that ability to see through walls reported above, Anselm was credited with wonder-working gifts. Eadmer tells us that Anselm was able simply with a look to cure a youth troubled with pain in his genitalia. He was also able to drive off the wolves, which a gravely ill monk imagined were attacking him ([12], I. xiv, pp. 23-24; I. xv, pp. 24-25). In the latter episode the invalid claimed that when Anselm 'came in the door and raised his hand to make the sign of the cross, he saw a tongue of flame come out of his mouth as if it were a lance hurled at the wolves' ([12], I. xv, p. 25). The motif of the divine fire was repeated in the story of the monk Riculfus who claimed to have seen Anselm at prayer in the midst of a ball of fire ([12], I. xvi, pp. 25-26). More mundane wonders were performed by Anselm when he miraculously provided food for his companions ([12], I. xvii, pp. 26-27; I. xviii, pp. 27-28). In these cases Anselm demonstrated that he was 'inspired by the spirit of prophecy' ([12], I. xviii, p. 28). Further evidence of Anselm's visionary gift was reported by Eadmer. During an illness, Anselm was 'caught up in the spirit of ecstasy' and was shown a raging torrent into which all the filth of the world flowed. The river sucked in men and women of all status and he was shocked to discover that they drank the filthy water and positively revelled in their fate. Anselm's spirit guide allowed him to view the 
true monastic vocation symbolised by a shining silver cloister with silvery grass underfoot. Eadmer assures his reader that Anselm understood that only the true monastic life was for him and he committed himself thenceforth to it. Interestingly, Eadmer tells us that Anselm was also committed to understanding the rational basis for the monastic life and communicating that to others ([12], I. xxi, pp. 35-36).

As portrayed by his biographer, Anselm was a miracle worker and Eadmer assures his readers that he might have included many more accounts of cures effected through the water in which Anselm had washed his hands and the morsels of food that had been secretly removed from his plate ([12], I. xxxv, pp. 61-62). Anselm's reputation for sanctity, his fama sanctitatis, enhanced his charismatic appeal and drew crowds of the laity as well as members of the Church in search of his help ([12], I. xxxii, pp. 57-59). Indeed, his fame crossed the divisions between faiths. Eadmer tells us that during Anselm's time in Southern Italy in 1098, the archbishop's saintly reputation was recognised by the Muslim troops in the service of Count Roger I of Sicily:

Some of them, I say, were stirred by the report of his goodness which circulated among them to frequent our lodging. They gratefully accepted offerings of food from Anselm and returned to their own people making known the wonderful kindness which they had experienced at his hands. As a result he was from this time held in such veneration among them, that when we passed through their camp-for they were all encamped together - a huge crowd of them, raising their hands to heaven, would call down blessings on his head; then kissing their hands, as they are wont, they would do him reverence on their bended knees giving thanks for his kindness and liberality.

Eadmer goes on to say that many of the Muslims would have converted there and then, had not the Count of Sicily threatened them ([12], II. xxxiii, pp. 111-12).

\section{Anselm and the Economics of Charisma}

Anselm, like many others identified as medieval charismatics, rejected the personal use of money. As a Benedictine monk he was vowed to poverty, but, it must be remembered, many monastic houses were among the wealthiest institutions in medieval society and those in positions of responsibility perforce had to deal with the acquisition and disbursement of money and the pressures of commercial transactions. However, it is argued that one of the ways that a charismatic leader obtained legitimate authority was to reject attachment to mundane routines. In this respect the tenets of medieval monasticism would seem to have provided the perfect foundation for such a leader. In a sense he was able to draw on the collective charisma of the monastic order itself. This collective charisma already marked out its adherents as standing outside the routine expectations of everyday life. One of the paradoxes of medieval monasticism, especially relating to new or reformed monastic orders, was that the very espousal of Apostolic poverty attracted wealth in the form of pious donation ([12], I. xxii, pp. 39-40). Patrons recognised that this purer form of monasticism was preferred as more efficacious for the soul's welfare. Thus, reconciling the financial success of a monastery with its spiritual mission became a problem for monastic authorities.

Anselm was careful to ensure that none of Bec's resources were seen to be his private property. Eadmer's text is interesting, but contradictory here because, at the same time as he explains that Anselm ensured that resources that had been assigned for his use during journeys made on the 
abbey's business were to be put at the disposal of anyone making such a journey, the abbot 'never held back from supplying the necessities of others from his own store' ([12], I. xxiii, p. 40). Great sums of gold and silver were offered to Anselm, but he made sure that they were given to the abbey and its monks. Eadmer suggested that this may have cost Bec some revenues as one donor made it clear that the gifts were for Anselm alone ([12], I. xxiii, p. 41). There is a hint in Eadmer's text that Anselm's professed abhorrence of wealth might not have been universally believed. In describing Anselm's preaching tours, Eadmer reported the story of the knight Cadulus who wanted to take up the monastic life. He was intercepted by the devil on his way to meet Anselm and asked why he wanted to see that 'hypocrite prior. Certainly his reputation is at variance with his manner of life...For this hypocrisy has already deceived many and, having buttered them up with vain hopes, has stripped them and left them destitute' ([12], I. xxv, p. 43). It may be significant that Anselm helped Cadulus find his monastic vocation, but persuaded him to become a monk at Marmoutier:

For it was Anselm's custom, notwithstanding any hope of advantage, never to persuade anyone who wished to renounce the world, to do so at his own monastery rather than elsewhere. And the consideration which led him to act thus was as follows: if anyone entered the monastery except as a result of his own deliberation, and then - as might happen - found it irksome and began to disparage it, he might attribute his own scandalized and impatient grumbling to Anselm's persuasion, and so make serious divisions between him and the others ([12], I. xxv, p. 43).

This might be seen as ensuring the continued harmony of the abbey under Anselm's control, but it could also be interpreted as an attempt to minimize the potential for damage to Anselm's reputation, should the monastic recruit prove less than satisfactory.

\section{Performing Charisma}

It has been observed that charisma demands an audience and it is thus important to recognise the performative aspect of charismatic authority ([16], pp. 767-68). The rituals and ceremonies that were expressive of, and constitutive of, medieval monasticism allowed those occupying positions in the monastic hierarchy to demonstrate their authority. Their words and actions were, in this respect, naturally the focus of the attention of their subordinates. If that attention wandered, there were officers empowered to remind the monks of their duty ([39], pp. 168-86). An aspect of Anselm's performance of charismatic authority was his ability to draw attention to himself through silence and inactivity. A passage in the Life of St Anselm describes his management of the secular affairs of the monastery of Bec. Eadmer pictures Anselm, by then abbot of the monastery, delegating most of the mundane business. However, whenever he was called to attend judicial assemblies, he adopted surprising tactics:

...when he was in a crowd of litigants and his opponents were laying their heads together, discussing the crafts and wiles by which they could help their own case and fraudulently injure his, he would have nothing to do with such things; instead, he would discourse to those who would listen about the Gospels or some other part of the Bible, or at least about some subject tending to edification. And often, if there was no-one to listen to such talk, he would compose himself, in the sweet quietness of a pure heart, to sleep. Then sometimes, when the frauds which had been prepared with intricate subtlety were brought to 
his notice he would immediately detect and disentangle them, not like a man who had just been sleeping, but like one who had been wide-awake, keeping a sharp watch ([12], I. xxvii, p. 46).

When his attempts to remind his adversaries that part of his authority lay in his command of the interpretation of Scripture were ignored, Anselm seems to have feigned indifference to the proceedings and this charismatic hauteur subsequently enabled him to catch off-guard his litigious opponents. This was a tactic that he was to employ later during his difficulties with the king (e.g., [2], p. 58). This suggests the charismatic leader's confidence in his own judgement and his willingness to flout convention and challenge tradition. Whether Anselm was asleep or not, his followers and those who found themselves faced with this sleeping monk in court, evidently noticed this singular display and were presumably disconcerted by it (cf. [40], pp. 51-55). Anselm's inaction was, in fact, highly effective engagement with his audience.

When he was unanimously elected as Herluin's successor as abbot of Bec, Anselm resisted the appointment with all his might. After reasoned argument failed, Anselm resorted to physical displays of supplication. Demonstrative bodily comportment was utilised in an attempt to appeal to the emotions of the monks of Bec. He threw himself down at their feet and with 'tears and pitiable sobs he begged and prayed, in the name of Almighty God, that if they had any bowels of mercy in them, they would act towards him with the mercy of God before their eyes, abandoning their attempt and allowing him to remain free of so great a burden.' However, the monks were equally versed in such rituals and similarly skilled in demonstrations of this sort. They, too, prostrated themselves 'and begged him to have mercy on the monastery and on themselves rather than on himself, lest putting aside the common good he should be convicted of loving himself alone before all others.' Eventually Anselm was instructed by Archbishop Maurilius of Rouen to accept the burden of office ([12], I. xxvi, pp. 44-45). The parallels with Anselm's election to the see of Canterbury are instructive and when that later episode is borne in mind, Eadmer's comment that 'such then was the violence with which he was made abbot' takes on something of a critical note ([12], I. xxvi, p. 45). There is a similar ironic twist in a letter from Abbot Fulk of Saint Pierre-sur-Dives to Anselm. Abbot Fulk quoted verbatim from a letter which Anselm had sent him on his own election to the abbacy, reminding him of his duty to accept the burden of office ([5], Volume III, pp. 213-14; [6], Volume I, No. 88, pp. 227-28). Was there a wry smile on Fulk's face as he composed his letter of encouragement to Anselm and dictated, 'It is indeed a wonderful victory to prevail over somebody with his own weapons'?

\section{Charisma and Fame: Anselm in England}

Anselm's fame preceded him when he made his first visit to England in 1079, the year of his consecration as abbot of Bec. It is at this point in the Vita Anselmi that its author, Eadmer, moves from being mere biographer to eye-witness and participant in events. 'It was at this time,' he tell us, 'that I too was found worthy to come to the notice of his holiness [et ego ad sanctitatis ejus notitiam pervenire merui] and, considering my insignificance - for I was only a youth - I enjoyed no small share of the blessing of his friendship.' The fact that Eadmer was a youth was important as it has been noted how Anselm paid special attention to the education of young men. Biographers occasionally find it difficult not to enhance their own standing by associating themselves with the 
virtues of their subjects, and it is thus significant that Eadmer added this autobiographical note just after telling his readers that Anselm was in the habit of talking privately with the more intelligent monks [cum iis qui profundioris ingenii erant] of Christ Church, Canterbury ([12], I. xxix, p. 50).

One of the main reasons for Anselm's visit to England was to inspect the estates of the abbey of Bec and to receive the oaths of homage from the monastery's tenants. On his travels, Anselm was a guest in many communities of monks, nuns and canons, as well as receiving the hospitality of certain noblemen. According to Eadmer, Anselm was cheerful and approachable, with the result that:

...the hearts of all, being wonderfully moved to love him, were seized with a ravenous hunger to hear his words. For he adapted his words to every class of men, so that his hearers declared that nothing could have been spoken that was more appropriate to their station. He spoke to monks, to clerks, and to laymen, ordering his words to the way of life of each.

Therefore the attraction of Anselm's sermons was that he preached ad status that is to the particular interests of his audience, winning them over as followers. He enabled his audience to understand complex ideas by drawing on metaphors culled from everyday life. His rhetorical skills and the force of his performance are reported as considerable, as was his ability to connect emotionally with his audience. His style, Eadmer suggests, departed from the usual:

And when we say that he admonished or instructed or taught these things, he did it not as others are wont to teach, but far differently; he set forth each point with familiar examples in daily life, supporting them with evidence of solid reason, and leaving them in the minds of his hearers, stripped of all ambiguity. Everyone therefore who could enjoy his conversation was glad to do so, for on any subject they wished he had heavenly counsel ready for them. Hence men and women of every age admired and loved him, and the more powerful and distinguished they were the more anxious and ready they were to serve him ([12], I. xxxi, p. 55).

Anselm's preaching was evidently directed at the interests of the different ranks of his audience, a technique known as ad status preaching (e.g., [41]). Such was Anselm's appeal that even the most prominent in secular society were also won over. Most notably the powerful king, William the Conqueror, a man with charisma of his own, who appeared intimidating, 'nevertheless unbent and was amiable with Anselm, so that to everyone's surprise he seemed an altogether different man when Anselm was present' ([12], I. xxxi, p. 56; [42]). The abbot of Bec, according to his biographer, made a considerable impact on England and the Normans who had settled there. 'The good report of Anselm thus became known in every part of England and he was beloved by everyone as a man to be revered for his sanctity' ([12], I. xxxi, p. 57). Fame adheres to the charismatic leader and might be judged an essential attribute given the leader's need for devoted followers. Fame also needs to be cultivated. The distinction between Weberian and popular charisma has been recognised, but here it is difficult to separate the concepts ([16], pp. 764-65). Did Anselm's sermons entertain as well as provide spiritual food for his audience? Could the people Eadmer writes about have been 'fans' of Anselm's preaching instead of, or as well as, followers of the man himself? Could they understand his words, or was his delivery, his performance, of sufficient strength to render the ability to understand his words irrelevant? Whether Anselm ever made use of the 'techniques of frenzy' is doubtful ([36], pp. 102-06), but whatever the answer to these questions, Anselm's reputation was assured and when the English 
Church faced a crisis during the reign of the Conqueror's successor, it was to the famously holy abbot of Bec that the people and clergy turned for help.

\section{Conclusions: Failed Charisma}

After a decade or more since his last recorded visit in 1079, Anselm returned to England in September 1092. Anselm's letters as abbot of Bec demonstrate that he had maintained contacts with England in the years between his visits, perhaps preparing the ground for his eventual elevation to Canterbury ([5], Volume III, pp. 213-94; [6], Volume I, pp. 225-334). However, several specific reasons are cited for his arrival in 1092: Hugh of Avranches, earl of Chester and many other noblemen in England had chosen Anselm as their spiritual physician and protector. He also had duties connected with Bec's estates in England ([12], II. i, p. 63; [2], pp. 27-29). Anselm arrived in Canterbury on 7 September 1092 and the next morning he set off for a meeting with the king before making his way to Chester. Eadmer tells us that the monks at Canterbury had welcomed Anselm and had immediately acclaimed him as archbishop, 'as if foretelling the future'. At Christmas that year he stayed in London, probably with his friend and pupil Gilbert Crispin the abbot of Westminster and another of the Bec alumni who formed a mutual support network throughout the Anglo-Norman regnum ([1], pp. 23-48). When Anselm attended the royal court he was welcomed eagerly by all the nobility and William Rufus himself rose from his throne and met him at the threshold of his hall joyfully ([12], II. i, pp. 63-64). Anselm spoke privately with the king and rebuked him for the things that were being reported about him, which 'by no means befitted the dignity of a king.' He then left for Chester ([12], II. i, p. 64). There he gave advice to the earl about plans to bring monks from Bec to the abbey of St Werburgh. It was during Anselm's stay with Earl Hugh that King William was struck down with the illness mentioned at the beginning of this paper.

There has been considerable debate about Anselm's investiture as archbishop of Canterbury, but here the focus is on the motives of those who put him forward for the post, rather than on the sincerity of Anselm's refusal to accept the office (e.g., [13], pp. 186-94). The medieval sources suggest that Anselm was an obvious candidate to succeed Lanfranc as archbishop. He was well-known to the English Church hierarchy and had found followers among the secular aristocracy. Even the king showed him respect and tolerated his moral criticisms. For the English Church this was a time of crisis, although whether Christianity itself was under threat is doubtful. Weber suggested that it is in moments of distress that charismatic saviours often emerge as natural leaders offering a path out of the crisis ([18], Volume II, pp. 1111-12; [14], p. 122). At just such a time of distress the collective will of the secular and ecclesiastical communities of England was that Anselm should become archbishop of Canterbury, and 'not a single voice was raised in objection' ([12], II. ii, p. 65). Anselm's authority was recognised and it was hoped that this saintly man, as a recognised charismatic leader, fortified with the added charisma of his monastic office and his reputation as a scholar, could guide the English Church out of its tribulations. In addition, Anselm's status as an 'adopted Norman' and his presumed command of the French language, as well as his relationship with the ducal and then royal house, would have ensured his acceptability 
to members of the Norman ruling class, both ecclesiastical and secular. ${ }^{2}$ Anselm was, as Eadmer noted, 'the man most fitted for the work' ([12], II. ii, p. 64). There were, however, dissenting voices and these belonged to the monks of Bec, Anselm's equally devoted followers in Normandy, who feared the loss of their charismatic abbot. The monks of Bec had a prior emotional and institutional claim on Anselm and he recognised the distress that his departure caused. The strength of feeling of the monks of Bec is understandable as, in a very real sense, they had been instrumental in fashioning Anselm's charismatic reputation. But despite their protests, Anselm submitted to the will of God, as he wrote in one of his letters, and accepted his elevation to Canterbury ([5], Volume IV, pp. 17-24; [6], II, No. 156, pp. 28-36). Their abbot, in whom they had invested so much, had abandoned the monks of Bec. In taking up the archiepiscopal office Anselm's charismatic authority, at least in the Norman abbey of Bec, began to dissolve just as it was being formed by the monks' counterparts in Christ Church, Canterbury.

This analysis of the early part of Anselm's career has attempted to make use of Weber's model of charismatic authority. Anselm's charisma operated on many levels and together these various manifestations of authority combined to make him one of the most influential figures of his day. However, his position as archbishop of Canterbury proved precarious and before the end of 1097 he was forced into exile ([12], II. xxii, p. 98; [2], pp. 87-88). As his relationship with William Rufus deteriorated, Anselm increasingly faced opposition from those who had seen in him a chance to restore the fortunes of the English Church. With each setback, the power of Anselm's charismatic authority, with the exception of his scholarly reputation, dwindled. Eventually, in England, just as in 1093 in the abbey of Bec, the spell was broken and there seems to have been no popular outcry at his treatment at the hands of the king and his officers. In 1097, Anselm fled the kingdom abandoning the English Church as he had abandoned the monks of Bec. His charismatic authority could not withstand the pressure applied by the king, an individual who also combined the charisma of office with personal charisma to expose and exploit the instability of his archbishop's pretensions to leadership. The archbishop may, after all, have been right to highlight the inequality in the relationship between the 'wild, untamed bull' William Rufus and the 'feeble, old sheep' Anselm. The governance of the medieval Church in any principality inevitably threw into sharp relief the charismatic foundations of the authority of the king and that of his leading prelates. This period in the history of the Latin Church is characterized by the sometimes violent search for a modus vivendi between what we might somewhat anachronistically term Church and State [43].

The crucial blow to Anselm's position was delivered by his followers in England, who simply lost faith in his charismatic authority. For Anselm it was a relief: 'being now out of England, [Anselm] rejoiced exceedingly and gave thanks repeatedly to God because he saw that he had escaped as from the great furnace of Babylon, and had attained a sort of peak of calmness and rest' ([12], II. xxiv, p. 100). The failure of Anselm's charismata to prevent the deterioration of his relationship with the king, nobles and clergy of England highlights the precarious nature of this type of authority. Resting as it does as much in the perceptions of the followers of charismatic

2 My thanks to Gary Dickson (personal communication) for this point. 
figures and their continued faith in their leader, as on the actions of the object of their devotion, this manifestation of authority is prone to sudden and devastating dissipation. ${ }^{3}$

\section{Acknowledgments}

I should like to record my thanks to Gary Dickson for inviting me to offer this article in response to the special edition of the journal and for his judicious comments on an earlier draft of this article. Thanks are also due to those who reviewed this article and made valuable suggestions for its improvement. Any faults that remain are the author's alone.

\section{Conflicts of Interest}

The author declares no conflict of interest.

\section{References}

1. Vaughn, Sally N. Archbishop Anselm 1093-1109. Bec Missionary, Canterbury Primate, Patriarch of Another World. Farnham, UK: Ashgate Publishing Ltd, 2012.

2. Eadmer. Historia Novorum in Anglia. Edited by Martin Rule. London, UK: Rolls Series, 1884.

3. Eadmer. Eadmer's History of Recent Events in England. Historia Novorum in Anglia. Translated by Geoffrey Bosanquet. London, UK: The Cresset Press, 1964.

4. Fröhlich, Walter. "Considerate ovem tauro copulastis. Anselm's relationship with King William II Rufus.” In Saint Anselm. Bishop and Thinker. Edited by Roman Majeran and Edward Iwo Zielinski. Lublin, Poland: The University Press of the Catholic University of Lublin, 1999, pp. 29-45.

5. F. S. Schmitt, ed. Anselmi Opera Omnia. Edinburgh, UK: Thomas Nelson and Sons, 1946-61.

6. Walter Fröhlich, trans. The Letters of Saint Anselm of Canterbury. Kalamazoo, MI, USA: Cistercian Publications, 1990-94.

7. Clark, William. Academic Charisma and the Origins of the Research University. Chicago, USA: The University of Chicago Press, 2006.

8. Heffernan, Thomas J. Sacred Biography. Saints and Their Biographers in the Middle Ages. Oxford, USA: Oxford University Press, 1988.

9. Vauchez, André. Sainthood in the Later Middle Ages. Cambridge, UK: Cambridge University Press, 2005.

10. Cowdrey, Herbert Edward John. Lanfranc. Scholar, Monk, and Archbishop. Oxford, UK: Oxford University Press, 2003.

11. Harper-Bill, Christopher. "Herluin, abbot of Bec, and his biographer." Studies in Church History 15 (1978): 15-25.

12. Eadmer. Vita Anselmi. The Life of St Anselm. Edited by R.W. Southern. Oxford, UK: Oxford University Press, 1972.

3 After the completion of this article, Professor Judith Green drew my attention to Samu Niskanen's study of the letters collections of Archbishop Anselm [44]. 
13. Southern, Richard William. Saint Anselm. A Portrait in a Landscape. Cambridge, UK: Cambridge University Press, 1990.

14. Potts, John. A History of Charisma. Basingstoke, UK: Palgrave Macmillan, 2009.

15. Weber, Max. The Theory of Social and Economic Organization. New York, USA: Simon \& Schuster, 1947.

16. Dickson, Gary. "Charisma, Medieval and Modern." Religions 3 (2012): 763-89.

17. Haley, Peter. "Rudolph Sohm on Charisma." The Journal of Religion 60, no. 2 (1980): 185-97.

18. Weber, Max. Economy and Society. An Outline of Interpretive Sociology. Edited by Guenther Roth and Claus Wittich. Berkeley, USA: University of California Press, 1968.

19. Southern, Richard William. Saint Anselm and His Biographer. Cambridge, UK: Cambridge University Press, 1963.

20. Eadmer of Canterbury, Lives and Miracles of Saints Oda, Dunstan and Oswald. Edited and translated by Andrew J. Turner and Bernard J. Muir. Oxford, UK: Oxford University Press, 2006.

21. Vaughn, Sally N. "Eadmer's Historia Novorum: A Reinterpretation." In Anglo-Norman Studies X. Proceedings of the Battle Conference 1987. Edited by R. Allen Brown. Woodbridge, UK: Boydell and Brewer Limited, 1988, pp. 259-89.

22. Staunton, Michael. "Eadmer's Vita Anselmi: A reinterpretation”. Journal of Medieval History 23, no. 1 (1997): 1-14.

23. Brian Davies, and G.R. Evans, eds. Anselm of Canterbury, the Major Works. Oxford, UK: Oxford University Press, 1998.

24. Ronald E. Pepin, trans. Anselm and Becket. Two Canterbury Saints' Lives by John of Salisbury. Toronto, Canada: Pontifical Institute of Medieval Studies, 2009.

25. Ward, Benedicta. Anselm of Canterbury. His Life and Legacy. London, UK: SPCK, 2009.

26. Justin McCann, trans. The Rule of St Benedict. London, UK: Sheed and Ward Ltd, 1976.

27. Weber, Max. The Protestant Ethic and the Spirit of Capitalism. London: Allen and Unwin, 1930.

28. Parkin, Frank. Max Weber. London, UK: Routledge, 2002.

29. D’Avray, David L. Medieval Religious Rationalities. A Weberian Analysis. Cambridge, UK: Cambridge University Press, 2010.

30. Aberbach, David. Charisma in Politics, Religion and the Media. Private Trauma, Public Ideals. Basingstoke, UK: Macmillan, 1996.

31. Sister Benedicta Ward, trans. The Prayers and Meditations of Saint Anselm with the Proslogion. Harmondsworth, UK: Penguin Books, 1973.

32. Crispin, Gilbert. "Vita Herluini." In The Works of Gilbert Crispin. Edited by Anna Sapir Abulafia and G.R. Evans. London, UK: Oxford University Press for the British Academy, 1986, pp. 183-212.

33. Crispin, Gilbert. "The Life of Lord Herluin, Abbot of Bec." In The Abbey of Bec and the Anglo-Norman State 1034-1136. Authored by Sally N. Vaughn. Woodbridge, UK: The Boydell Press, 1981, pp. 67-86.

34. Morrison, Karl. Marx, Durkheim, Weber. Formations of Modern Social Thought. London, UK: Sage Publications, 1995. 
35. Aird, William M. "The Tears of Bishop Gundulf: Gender, Religion, and Emotion in the Late Eleventh Century." In Intersections of Gender, Religion and Ethnicity in the Middle Ages. Edited by Cordelia Beattie and Kirsten A. Fenton. Basingstoke, UK: Palgrave Macmillan, 2011, pp. 62-84.

36. Lindholm, Charles. Charisma. Oxford, UK: Blackwell, 1990.

37. Vaughn, Sally N. "Anselm of Bec: The Pattern of His Teaching." In Teaching and Learning in Northern Europe, 1000-1200. Edited by Sally N. Vaughn and Jay Rubenstein. Turnhout, Belgium: Brepols, 2000, pp. 99-128.

38. Brian Davies, and Brian Leftow, trans. The Cambridge Companion to Anselm. Cambridge, UK: Cambridge University Press, 2004.

39. Burton, Janet. Monastic and Religious Orders in Britain, 1000-1300. Cambridge, UK: Cambridge University Press, 1994.

40. Brubaker, Leslie. "Gesture in Byzantium." In The Politics of Gesture. Historical Perspectives. Edited by Michael J. Braddick. Oxford, UK: Oxford University Press, 2009, pp. 36-56.

41. Tausche, M., and D'Avray, David L. "Marriage sermons in ad status collections of the central Middle Ages." In Modern Questions about Medieval Sermons. Essays on Marriage, Death, History and Sanctity. Edited by Nicole Bériou and David L. D’Avray. Spoleto, Italy: Centro Italiano di Studi sull'Alto Medioevo, 1994, pp. 77-134.

42. Fröhlich, Walter. "St Anselm's special relationship with William the Conqueror." In Anglo-Norman Studies X. Proceedings of the Battle Conference 1987. Edited by R. Allen Brown. Woodbridge, UK: Boydell and Brewer Limited, 1988, pp. 101-10.

43. Cushing, Kathleen G. Reform and the Papacy in the Eleventh Century: Spirituality and Social Change. Manchester, UK: Manchester University Press, 2005.

44. Samu Niskanen. The Letter Collections of Anselm of Canterbury (Instrumenta Patristica et Mediaevalia). Turnhout, Belgium: Brepols, 2011. 
Reprinted from Religions. Cite as: Clanchy, M. "Abelard: Celebrity and Charisma-A Response to Dickson." Religions 3 (2012): 1140-1143.

\title{
Abelard: Celebrity and Charisma-A Response to Dickson
}

\section{Michael Clanchy}

\begin{abstract}
One might think that Peter Abelard (1079?-1144?) would be the best example of a medieval charismatic teacher. But his rival and prosecutor St Bernard of Clairvaux (1090?-1153) fits the criteria rather better. Unlike Bernard, Abelard denied that he had sought out disciples. Nevertheless, he can be shown to have had student followers, even though some of them repudiated him. Abelard is most important as a public intellectual who depended on public institutions (the incipient university of Paris) rather than on private or monastic patronage.
\end{abstract}

'Celebrity' is more straightforward than 'charisma'. I think the concept of 'celebrity' (fama) is evident in Heloise's praise of Abelard and similarly in Peter the Venerable. Heloise asks: 'What king or philosopher could equal your fame?' ([1], p. 1; [2], p. 115, 11. 186-93). This is extravagant of course; but the idea of fame is there. It is also present in Peter the Venerable's letter to Heloise, when he says of Abelard that 'he was known throughout almost the whole world and was famous everywhere' (toti pene orbi terrarum notus, et ubique famosus erat) ([1], p. 96). ${ }^{1}$ But Peter goes on to modify this by referring to Matthew's gospel $(11,29)$ : 'Learn of me, for I am meek and lowly in heart.' ([3], letter 115, p. 307). So Peter the Venerable has Abelard famed for his humility, whereas according to St Bernard (his prosecutor at the council of Sens in 1140/1141) he was notorious for his pride. By likening Abelard to Goliath, who was thought of as the epitome of pride, Bernard signified this deadly sin in Abelard ([1], p. 311; [4], VIII, letter 189, p. 14, 1. 1). In his letter to Pope Innocent II, Peter the Venerable compares Abelard's disposition to that of a sparrow or turtle-dove, which was perhaps taking the rhetoric of understatement and humility too far ([1], p. 323). Yet in his epitaph for Abelard, Peter describes him as 'the world's acknowledged prince of learning' (studiorum cognitus orbi princeps) ([5], p. 103; [1], p. 324). The idea of fame is alluded to in my essay on 'Abelard and the individual in history' ([6], p. 294). The medieval concept of fama has also been recently surveyed, although chiefly in legal and literary terms [7].

'Charisma' is more complicated. Abelard denied that he sought out followers. In his 'General Confession of Faith' dating from the time of his condemnation following the council of Sens, he says: 'Whatever I have written I have shown freely to everybody, so that I should have judges and not disciples' (quecumque scripsi libenter omnibus exposui ut eos iudices non discipulos haberem) ([8], p. 133). Nevertheless, as Dickson indicates, in Abelard's autobiography (his Historia

All Latin translations are by the author. 
Calamitatum) he does indeed describe students seeking him out, when he was at his hermitage of the Paraclete near Troyes ([9], p. 92, 1. 1045). Abelard likewise describes, a year or two earlier, when he was a monk of St Denis, how 'such a multitude of students' (scolares) followed him to his 'cell' that lodgings and food were inadequate ([9], p. 82, 11. 666-67). Abelard maintains that students sought him out because he argued things from reason ([9], pp. 82-83, 11. 690-701); he does not say that they necessarily found him a pleasant person. Reasoning is consistent with Peter the Venerable's epitaph, where Abelard is described as 'overcoming everything by force of reason' (omnia vi superans rationis) ([5], p.103).

When Abelard was teaching at the hermitage of the Paraclete, one of his students, Hilary of Orléans, a distinguished Latin poet, was prompted to write a poem describing a crisis at the school. The students had evidently misbehaved. Abelard ordered them all to take up lodgings in a nearby village. The Latin verses of this poem each have a French refrain: 'the master has done wrong to us' ([1], pp. 240-41; [10], pp. 30-31). The poem claims that rumor is leading to hatred of Abelard ([10], pp. 30-31, 1.7); he is a 'hard master' (1.21). 'We are the many (the poem declares) who have come together from all over the place, for whom the fount of logic was overflowing; but the greatest and the least [of us] may depart, if what we have sought here is denied us' ([10], pp. 30-31, 11. 36-40); 'if you wish to deny us help, this place will not have the name of a place of prayer (oratory) but a place of tears (ploratory)' ([10], pp. 30-31, 11. 47-49). As described in this poem, the students are fickle in their loyalties; they will leave, if Abelard fails to satisfy them.

Dickson needs to make it clear that Abelard was accused of heresy twice (in 1121 and 1140/1141), on both occasions because of his book Theologia [1], pp. 266-72, pp. 289, 307-10, 317-19). These accusations were not connected with his flight from the abbey of St Denis in 1121, which was occasioned by his questioning the identity of St Denis. Regarding Abelard's fama, the first condemnation in 1121 did not destroy him, as he describes in Historia Calamitatum how he recovered ([2], pp. 82-83). Similarly, the second papal condemnation in 1140/1141 did not destroy him everywhere, since Peter the Venerable protected him. As abbot of Cluny, Peter the Venerable was powerful enough to arrange a settlement in Abelard's favor.

One reason why Abelard was accused of heresy is because he had a following. In the Historia Calamitatum he describes coming to his trial at Soissons in 1121 with 'our disciples' ('discipulis nostris') ([2], p. 83, 1. 724). Abelard may have been seeking comparison with Christ here, with whom on more than one occasion he likens himself, whether in suffering, experiencing persecution, or in showing fortitude ([1], pp. 125, 145, 183, 216-17, 312). Similarly at the council of Sens in 1140/1141 the archbishop of Sens describes Abelard coming with his 'supporters' or 'partisans' ('fautoribus') ([1], pp. 312, 391 n. 138). As distinct from propaganda, there is evidence that Abelard had actual followers, which meets the criterion of Weberian charisma ([11], chs. 1 and 2).

St. Bernard, rather than Abelard, is perhaps the best example in the twelfth century of a charismatic teacher, who depended for his reputation on the widespread circulation of his letters and sermons. Referring to St. Bernard in his Apologia, Abelard's defender Berengar of Poitiers writes: 'People are astonished that you, who are ignorant of the liberal arts, have so great a wealth of eloquence that your effusions have now covered the entire surface of the earth' (Mirantur homines in te, liberalium disciplinarum ignaro, tantam ubertatem facundiae, quia emissiones tuae iam cooperuerunt universam superficiem terrae) ([12], p. 111). Irony or praise? Berengar wanted 
his readers to decide what he meant as irony and what as praise, though this is difficult for us now because of the barrier of Latin.

Like others accused of heresy, Abelard was alleged to be the leader of a sect: the letter of the archbishop of Sens to Innocent II in 1140/1141 describes Abelard's following: 'throughout almost the whole of France, in cities, villages and castles, disputes are carried on by students - not only within the schools but also in public places - and not by the learned or by those who are most advanced, but by boys and simpletons or even by fools' (per totam fere Galliam in civitatibus, vicis et castellis, a scholaribus, non solum intra scholas, sed etiam triviatim, nec a litteratis aut provectis tantum, sed a pueris et simplicibus, aut certe stultis) ([13], 189, 11. 84-5, 190, 11. 94-96). Abelard continued to have followers after his death ([11], chs. 1-2). In 1148, six years after Abelard's death, a presumed former student of his recorded Abelard's opinions on ethics, without disapproval, in the margins and spaces of a manuscript in Old English ([14], pp. 163-86). This raises the question as to whether this writer knew that Abelard was a heretic, whose books had been burned at St Peter's Rome ([1], pp. 304-05).

The above discussion makes clear that Abelard's place as a public intellectual is an important theme. This has not been much examined in the literature, despite St Bernard's accusations that Abelard was a self-publicist. The great medieval schoolmen, like Abelard and Aquinas, were public intellectuals because they taught in public institutions and they published some of their thinking in writings, which were widely circulated.

\section{References}

1. M. T. Clanchy. Abelard: a Medieval Life. Oxford, UK and Cambridge, MA, USA: Blackwell, 1997.

2. Heloise. "Letters, i \& ii." In Historia Calamitatum, by Peter Abelard, edited by Jacques Monfrin. Paris: J. Vrin, 1959, 111-24.

3. Peter the Venerable. The Letters of Peter the Venerable, edited by Giles Constable. Cambridge, MA, USA: Harvard University Press, 1967, I, letter 115.

4. Bernard of Clairvaux. Sancti Bernardi Opera, edited by Jean Leclercq, C.H. Talbot, H.M. Rochais. Rome: Cistercienses, 1957-1977, 8 v. in 9, VIII.

5. Petri Abaelardi Abbatis Rugensis. Opera Omnia, edited by J.-P. Migne. Patrologiae: Series Latina. Paris: Garnier Fratres, 1855, CLXXVIII, 103.

6. M. T. Clanchy. "Documenting the Self: Abelard and the Individual in History." Historical Research 76 (2003): 293-309.

7. Thelma Fenster, and Daniel Lord Smail, eds. Fama: the Politics of Talk and Reputation in Medieval Europe. Ithaca and London: Cornell University Press, 2003.

8. Charles S.F. Burnett. "Peter Abelard, Confessio Fidei Universalis: A Critical Edition of Abelard's Reply to Accusations of Heresy." Mediaeval Studies 48 (1986): 111-38.

9. Peter Abelard. Historia Calamitatum, edited by Jacques Monfrin. Paris: J. Vrin, 1959.

10. Hilarii Aurelianensis. Versus et Ludi, Epistolae, edited by Walther Bulst, Marie Luise Bulst-Thiele and Mathias Bielitz. Leiden: E.J. Brill, 1989, 30-31.

11. David Luscombe. The School of Peter Abelard. Cambridge, UK: Cambridge University Press, 1969, chs. 1-2. 
12. Berengar of Poitiers. Apologia, edited by Rodney Thomson. Mediaeval Studies 42 (1980): 111.

13. Letter of Henry, archbishop of Sens to Pope Innocent II in 1140/1141. In 'Sapientia Doctrina': Mélanges offerts à Hildebrand Bascour, edited by Jean Leclercq. Leuven: Abbaye du mont César, 1980, 189, 11. 84-5, 190, 11. 94-96.

14. Charles Burnett, and David Luscombe. "A New Student for Peter Abelard: the Marginalia in British Library MS Cotton Faustina A. X.” In Itinéraires de la Raison: Etudes de Philosophie Médiévale Offertes à Maria Cândida Pacheco, edited by J. F. Meirinhos. Louvain-la-Neuve: Fédération Internationale des Instituts d'Études Médiévales, 2005, 163-86. 
Reprinted from Religions. Cite as: Brown, A. "Charisma and Routine: Shaping the Memory of Brother Richard and Joan of Arc." Religions 3 (2012): 1162-1179.

\title{
Charisma and Routine: Shaping the Memory of Brother Richard and Joan of Arc
}

\author{
Andrew Brown
}

\begin{abstract}
The extraordinary life and fate of Joan of Arc are well known; so is her association with the prophetic preacher, Brother Richard, who predicted the Apocalypse. Less well explained is why contemporaries initially took such an interest in this association, and how and why it began to fade from official memory after Joan's death. Max Weber's concepts of "charisma" and "routinization" offer valuable tools to deal with these questions. Both Joan and Richard have earned the title "charismatic" but interest in the preacher has generally been secondary to interest in the Maid. A more rigorous adoption of Weber's meaning of charisma, however, helps to clarify what the relative importance of these figures was in the eyes of contemporaries. It also shifts attention to the significance of messianic prophecy in the years surrounding Joan's life, the anxieties it generated and the way it was dealt with. In this context, the processions and commemorative ceremonies organized by townspeople, churchmen and royalty during this period deserve further analysis. Seen as forces of "routine", these ceremonies assume a greater significance than they have usually been granted, as processes that managed the memory of charismatic phenomena.
\end{abstract}

\section{Introduction}

Early in April 1429, the grey friar Brother Richard arrived in Paris ([1], pp. 233-37). For a fortnight he preached almost every day for five hours at several locations to crowds of five or six thousand. His message was apocalyptic. He claimed to have returned recently from Jerusalem where Jews had told him of the imminent birth of the Antichrist. Evidently he combined captivating oratory with a flair for dramatic technique. At the church of the Innocents, he preached from a high platform with his back to the charnel-houses, near the new mural depicting the Danse Macabre ([2], pp. 131-62.) ${ }^{1}$ On St Mark's day, the people of Paris were so "moved and stirred up to devotion" that within a few hours, 100 fires were lit in order to burn every kind of "covetous" game (chess, cards, dice and balls) that caused anger and swearing. Then women burned all their fine headgear in public. Some burned mandrakes that they had kept hidden away having believed these would make them rich: Brother Richard spoke "severely against this folly" as nothing but

1 The mural depicting the Dance of Death, with all members of society being swept off to their doom, had been painted just five years before [2]. 
"witchcraft and heresy". According to the Bourgeois of Paris (an anonymous clerk of the university of Paris, and probably a canon at Notre-Dame), no preacher in the previous century had so turned the people to piety. When he left Paris, everyone wept as bitterly as if they had been watching the burial of their dearest friends.

Brother Richard departed prophesying "the greatest wonders that had ever happened" for the year to come. As a messianic preacher calling for moral reform, judged by his audiences to be endowed with extraordinary powers, inspiring followers to change their lives, he undoubtedly fits Weber's ideal-type of "charismatic leader", the would-be agent of "a radical alteration of... structures of the 'world'." ([3], pp. 46-47, 53, 104, 151-52; [4], pp. 360-63). As Gary Dickson writes, this kind of charisma for Weber was essentially ephemeral ([5], p. 765; [3], p. 78; [4], p. 364); and in Brother Richard's case, as far as Parisians were concerned, it was fleeting indeed. Two months after he had left, he was held in so much contempt that the games he had forbidden were being played once more ([1], pp. 242-43). He disappears from the Bourgeois of Paris' account, almost from other sources, and is consequently neglected by modern historians. It is of course another figure, Joan of Arc, who draws the bulk of attention, and interest in Brother Richard is subservient to his association with her ([6], pp. 260-68; [7,8]; [9], pp. 362-63; [10], p. 234; [11], pp. 31-32). The Bourgeois of Paris passes directly from the preaching of Richard to the deeds of Joan: her part in the raising of the siege of Orléans therefore appears to be one of the "wonders" that Brother Richard foretold. To Joan's supporters, this extraordinary feat was miraculous; to her detractors it was the result of more satanic influences. It is no accident that the Bourgeois, incensed by Joan's assaults on Paris, introduces her into his account immediately after referring to the burning of mandrakes ([1], p. 237).

In recent historiography, Joan's extraordinariness has also earned her the epithet "charismatic" ([12], p. 29). Whether Weber's definition of charisma applies to Joan as well as it does to Brother Richard, is debatable. Weber does not appear to have envisaged charismatic leadership by females as typical: perhaps his definition does not deal sufficiently with gender and with the qualities that were considered extraordinary enough in women to permit them to be leaders of men. On the other hand, he does not preclude the possibility that women could manifest charismatic behaviour ([3], p. 104; [5], pp. 764 note 2, 770, 779-80); and his crucial emphasis on charisma as a matter of perception ([5], p. 766; [4], p. 359) is prompt enough to encourage further inquiry into the charismatic qualities that in any given period were deemed particular to women and to men, or appropriate for the one or the other.

This article, however, deals with gendered differences in charisma only in passing, and instead pursues lines of enquiry that are more central to Weberian analysis: the relationship between charisma and the "routine" or the "ritualistic" ([3], pp. 60-61, 66-67, 74-75, 187-88, 262; [4], pp. 361-63). The prophet and the "representative of the priestly tradition" are set apart. The charisma of the prophet is different from the kind of charisma (Amtscharisma) possessed by the "technicians of the routine cults" ([3], pp. 66-67). Weber was more concerned with change than continuity, more with the kind of prophetic charisma that could overcome tradition than with the efforts of authorities to maintain it. But he recognized the power of forces that opposed "pneumatic" manifestations of charisma, and of suspicion raised among its enforcers towards individuals seeking grace by their own unaided means ([3], pp. 187-88). Evidence for such power is not hard to find in 
the treatment of Brother Richard, who was ejected from Paris at the orders of the theology faculty of the university, and imprisoned at Poitiers in March 1430. Like many other charismatic individuals, Richard was muzzled.

Yet suppression was not the only means by which prophetic charisma was controlled. Weber's analysis encourages enquiry into other processes that might be at work. His notion of "routinization" is particularly valuable in this context. By this, Weber principally meant a process through which the enthusiasm generated by the prophet and his followers might be channelled into the foundation of a community or religious order, give way to the "forces of everyday routine", and thus lose its radical character ([3], pp. 60-61; [4], pp. 363-73, esp. p. 370). His analysis of this process (in The Theory of Social and Economic Organization) focused on the motives of followers that might lead to the "traditionalizing" of charismatic authority ([4], pp. 364-66); but his discussion of two "sharply" opposing types of authority, the "traditional" and "bureaucratic" ([4], p. 361), sets up the possibility that the process was also one forced on followers by those who opposed their aims. In The Sociology of Religion, Weber implies that a priesthood could appropriate the ideas of prophetic movements: "it might compromise with the new policy, surpass its doctrines, or conquer it" ([3], pp. 66-67). It is therefore worth extending the notion of "routinization" to include the responses that authorities made to the charismatic, in this case to the troublesome Brother Richard and Joan of Arc. In particular, the sermons preached by churchmen and processions performed by lay and ecclesiastical authorities during this period, may be usefully understood as responses that in certain circumstances managed "prophetic charisma".

The disturbances created by Richard and Joan did not end with their passing. Authorities that dealt with their activities when they were alive, had also to deal with memory of them after their death. This article will therefore touch on the final question raised by Gary Dickson in his article on "Charisma: Medieval and Modern," that is the extent to which prophetic charisma might outlive its perceived possessor ([5], p. 781). The afterlife of charisma is also about its memory, and the processes by which it was managed. These processes may also be framed as a type of "routinization". Sermon and procession dealt with disturbing events and individuals in the short term; over time the repetition of processions, and commemoration in chronicles and further ceremonies, served to shape and contain their memory. The fixing of social memory is perhaps most strongly secured by institutionalized commemoration ([13], pp. x, 14-15, 92-96, 127-37, 157-58). Joan of Arc was burnt as an idolator and heretic, but Valois rehabilitation of her name eventually guaranteed a hallowed place for her in the consciousness of a nation. But the process of remembering is also a process of forgetting. Uncomfortable aspects of Joan's activities were removed from later official accounts. Meanwhile Brother Richard all but vanished from documented record. Commemorating the Maid and dispatching the preacher to oblivion may be interpreted as part of the same process of "routinization".

The value of Weber's ideal-types and concepts to the historian is not that they provide models to apply rigidly to the past, but that they offer frameworks for research, or apertures through which the past might be viewed in new or revealing ways. "Charisma" and "routinization" are lenses for

2 D'Avray terms Weber's ideal-type as a "simplified schema" that Weber invites us "to try ... for size in empirical investigation," and to alter "if it does not fit" ([14], pp. 17-18). 
viewing the familiar events surrounding Joan of Arc from a fresh perspective. One of the incidental effects of this view is to bring Brother Richard back into sharper focus in terms of his significance to contemporaries.

\section{The Charisma of Brother Richard and Joan of Arc}

"Preaching unfolds its power most strongly", wrote Weber, "in periods of prophetic excitation" ([3], p. 75). The early fifteenth century was a period when messianic expectations were particularly high. The threat of social revolt, that had been so dangerous to authority in the 1380s, remained a fear in the minds of ruling groups. The Hussite rebellion seemed in the 1420 s to present the worst combination of social and religious upheaval. The Papal Schism had been deeply troubling to ecclesiastical authority, and its effects continued long after the Schism was healed in 1417. Joan of Arc herself was made aware of both Hussite threat and the Schism ([11], pp. 122-23; [15], V, pp. 156-59). Treatises on the sick state of the church continued to urge reform at the highest levels, but anxieties about the urgency of reform penetrated lower down the social hierarchy. Brother Richard was one in a succession of preachers who had excited fears that the devil or the Antichrist was loose in the world. Vincent Ferrer (d.1419) had for a time preached support for the Avignon pope, and mesmerized crowds in northern France by the apocalyptic tenor of his sermons ([8]; [16], pp. 317-18). In northern Italy, Bernadino of Siena (d.1444) was the most renowned of several preachers (from the Franciscan observance) who urged moral and social reform among townsmen [17].

Such preachers drew ambivalent responses from their audiences. On the one hand, in some towns they could enjoy the temporary support of municipal authorities, who might draft the moralizing tone of their sermons into civic legislation ([18], pp. 54-55; [17]; [14], pp. 103-05). On the other hand, their apocalyptic predictions were treated more warily. Even Bernadino of Siena, who was to be canonized in 1450 with unusual speed after his death, had initially been denounced (by Dominicans) for his encouragement of the cult of the Name of Jesus: its messianic undertones were deemed satanic. This denunciation was partly the result of rivalry between mendicant orders, but it also reflects a wider uncertainty among churchmen regarding what or who was truly holy. The appearance of holiness could easily mask the presence of evil; and in a climate of heightened fervour, detecting the differences between the two had become more urgent and difficult. ${ }^{3}$

Prophetic excitation ran high in war-torn France. ${ }^{4}$ In the late $1420 \mathrm{~s}$, the Bourgeois of Paris recorded events that might easily have been interpreted as signs of an approaching Apocalypse: the corrupt air causing illness and hacking coughs that disturbed the preaching of sermons; the plague of caterpillars devouring vines, almonds and walnuts; and in June 1429 outside Paris the birth of Siamese twins who attracted 10,000 Parisians out of the city to gawp at them ([1], pp. 222-24,

3 For Vincent Ferrer's own sermon on the dangers of demonic enchanters like Simon Magus, see [19], pp. 53-54. For Jean Gerson's tract on the discernment of spirits, see [20].

4 Monstrelet was to recall the fulminations of another disciple of Vincent Ferrer, the friar Thomas Connecte, against the luxurious living of the inhabitants of Valenciennes and those of other towns in Northern France in 1428 ([21], IV, p. 305). Other sources suggest that Thomas' preaching was more messianic than Monstrelet reports ([22], pp. 229-30). 
238-39). In August 1431, shortly after the burning of Joan of Arc, citizens were acutely agitated by the appearance of a batch of bread that, despite being made with excellent flour, emerged from the oven with the colour of cinders. To some this was a miracle, since the bread was baked on the Assumption; but to others it presaged something dreadful ([1], p. 273). In this climate of excited anxiety, preachers of dubious reputations preyed on receptive audiences. Twelve "penitents" who preached in Paris in 1427 had all the outward marks of holiness: a blessing from the pope and an appearance of poverty. According to the Bourgeois, however, they had sorceresses among them, caused trouble in marriages, and by magic arts or the devil's help made money flow out of other people's purses into their own ([1], p. 220). In 1446 a young preacher came to Paris, whose talents in medicine, law, theology, painting and fighting were so astonishing, that it seemed to many that he might be the Antichrist himself ([1], pp. 381-82).

Brother Richard's preaching was also variously regarded. At Orléans he won prolonged support: in 1430 he preached for twenty-three days in Lent, and enjoyed the hospitality of a local family. Like Bernadino of Siena he appears to have distributed medallions marked with the Name of Jesus ([23], pp. 234, 236, 238, 242, 246). But a letter from the town of Châlons to Rheims in July 1429 had already identified him as a sorcerer ([15], IV, p. 288). His moment of favour in Paris was brief, according to the Bourgeois, partly because he was soon discovered to be in the enemy camp, with the Valois army that besieged Paris in September 1429 - and in the company of Joan of Arc ([1], pp. 242-43). According to the greffier of La Rochelle, Brother Richard had also prepared the way for Joan's arrival at Troyes, on the road to Rheims for the crowning of the dauphin Charles. Richard went out of the town gates to kneel before her, and then ceaselessly preached in streets and public places until he had persuaded all the inhabitants to open their doors to Joan and the rightful king. Her arrival was an apocalyptic moment: Brother Richard preached that she had penetrated the secrets of God known only by the greatest of saints in paradise ([24], pp. 336-37). ${ }^{5}$

Joan was also perceived as possessing extraordinary powers in the earliest accounts of her deeds. The anonymous cordelier friar wrote (c.1432) that rumours of her miracles reached as far as Rome; people of towns disobedient to the dauphin were "transformed and overcome, and had no power to defend themselves against her" ([25], p. 73). This power was acknowledged by her opponents, although to the duke of Bedford in 1434, her ability to "drain the courage of her foes" was the result of sorcery and her discipleship of the "fiend" ([15], V, p. 136). Chastellain, echoing Joan's interrogators at Rouen, considered that the French people had wanted to make her their idol ([15], IV, p. 442). An ambivalence was shown towards Joan as it was towards charismatic preachers, an ambivalence made sharper in her case because of the troublesome way she appeared to cross gender boundaries. To the Bourgeois of Paris, she was the "accursed maid" whose very gender was in doubt: "what it was, God only knows" ([1], p. 244). ${ }^{6}$ The difficulty felt by theologians of distinguishing the holy from the unholy was particularly taxing when it came to visionary women. In her trial at Rouen, the judges asked Joan about her knowledge of mandrakes;

5 Jean de Chatillon, lord of Troissy, had also apparently attributed the king's entry into Troyes to the influence of Brother Richard ([15], IV, p. 296).

6 The Bourgeois also refers to doubt about Joan's gender at her burning: she was apparently pulled from the flames "et fut veue de tout le people et tous les secrez quie pevent estre ou doyvet [estre] en femme, pour oster les doubtes du people" ([1], p. 269). Chastellain considered Joan to be "passant nature de femme" ([15], IV, p. 446). 
and only a few years later she appeared in Johannes Nider's Formicarius (1437) as an example of the devil-worshipping witch who had begun to terrorize the imaginations of clerics [26].

The similarities between Joan and other extraordinary women in this period have been well explored. Vauchez drew attention to the disproportionate number of female visionaries and prophets who appeared during the Schism, some of whom achieved access to papal, episcopal and, like Joan of Arc, royal households. Kings of France had frequently bent an ear to the words of male and female visionaries $[27,28]$. Yet there were significant ways in which visionary females were distinguished from their male counterparts. By her frequent requests for communion, Joan shared in a kind of piety - an intense devotion to the Eucharist - that was particular to women mystics ([29], pp. 12-13, 17). On the other hand, female visionaries were excluded from the role of preaching. ${ }^{7}$ While male prophets could hold large crowds captive by their sermons in public spaces, female visionaries spoke indoors before influential but restricted audiences. Their message to popes or kings might touch on the apocalyptic, but they rarely appear to have predicted the imminent arrival of the Antichrist, as some male preachers did with such profligacy ([31], pp. 61-95; [28], pp. 277-81; [10], p. 228). Women might be permitted to "teach", possibly in public as St Katherine of Alexandria had done (and whom Joan claimed to have seen in her visions), but even this was a role model that could not be adopted by women with ease. ${ }^{8}$ The extraordinary qualities in visionary women that most impressed male and clerical admirers did not usually involve their powers of speech. Colette de Corbie, whom Joan of Arc possibly met, was noted for her visions in ecstatic trances - during which she was completely unable to speak ([6], p. 288; [33], pp. 51-62, 74-94; [10], p. 229; [12], p. 38; [34], pp. 188-92).

There are hints of the messianic in the letters that Joan of Arc apparently wrote. She refers to the possibility of a crusade to recover the Holy Land. Her reference to the name of Jesus (that appeared also on her banners), may represent an undercurrent of messianic expectation that was associated with Bernadino of Siena's cult of the Name ([15], V, pp. 126-27). Yet these are hints only, and carry none of the overt message of reform and apocalypticism that characterized the sermons of Bernadino - or those of Brother Richard. The Bourgeois of Paris wrote that she claimed to foretell the future ([1], p. 237), but her prophecies, though divinely inspired according to her supporters, were apparently limited to the restoration of the Valois monarchy ([15], I, pp. 221-22). Although "extraordinary", she is not the agent of structural change in the sense that Weber meant. Exclusion from the role of preaching, as perhaps Weber implies, tended towards the exclusion of women from the role of reforming agent.

Yet the "charisma" attributed to individuals, as Weber emphasizes, lay ultimately in the eye of the beholder, and eyes that beheld Joan saw a strong association between her and the male prophet. In the earliest reports of her deeds, particularly in hostile sources, her connection with Brother Richard is perceived as close. The duke of Bedford on 7 August 1429 wrote to the dauphin Charles, demanding that he produce for correction both Joan "the deformed woman" and Richard, the

7 Though for limited and exceptional occasions when women were invited to preach, see for instance [30].

8 Another extraordinary and loquacious visionary, Margery Kempe (in The Book of Margery Kempe c.1438), who also had visions of St Katherine, is flatly informed by the Mayor of Leicester that this saint "ar ye not lyche" ([32], p. 113). 
"apostate seditious mendicant friar" ([15], I, p. 382). ${ }^{9}$ The Bourgeois of Paris thought Joan to have been in Richard's thrall. A sermon preached in Paris by the Dominican inquisitor, Jean Graverent, on 9 August 1431, after the burning of Joan, claimed that there were three other women captured with her: all of them had been under the direction of Brother Richard, their confessor ([1], p. 271). This claim may simply reflect an assumption that Joan as a woman would not have been acting alone. Certainly, Joan's own testimony suggests greater distance between herself and the preacher: she had never seen him before her arrival at Troyes (in July 1429) and could not remember if he had entered the town with her. Asked if Brother Richard had given a sermon after her arrival - which according to the greffier of La Rochelle had been so influential — she said she did not know ([15], I, pp. 99-100, 102, 291). But the facts about the relationship between Joan and Richard, whatever these were, are less significant than perceptions of it. The need felt by inquisitors to question Joan so closely about Brother Richard reveals that an association with him was considered damning and disturbing. There were therefore many reasons to regard Joan as extraordinary, but what made her dangerous - and thus "charismatic" - in the eyes of her detractors was her connection with prophets who predicted apocalyptic change.

\section{Responses to Charisma}

The connection between Brother Richard and Joan of Arc, the one strengthening the charisma of the other, suggests another potential quality of charisma itself: that it could be passed on from one individual to another, and therefore survive the death of the individual who possessed it. Weber located charisma chiefly in the emotional excitement that individuals inspired: by implication it was unlikely to outlive its generator. Yet he did hint at the possibility of a charismatic afterlife. ${ }^{10}$ The "pneumatic" qualities of a prophetic preacher were unpredictable, and they could continue "without and beyond him as the object of a cult" ([3], p. 78). Unlike Bernadino of Siena, Brother Richard failed to inspire long-term disciples, and Joan of Arc (at least initially) did not generate a holy cult. Yet among their opponents there were fears - a perception at least - that they had the potential to do both.

Preachers could evidently draw over themselves the mantle of other prophets whose powers had already been acknowledged. In his last sermon to the Parisians, Brother Richard called on the authority both of "his master" Vincent Ferrer, and of Bernadino, "one of the greatest preachers in the world", to strengthen his prediction of great "wonders" to come ([1], pp. 235-36). Of Joan, the Bourgeois records rumours among the people that she had been "martyred" ([1], p. 354). Besides burning her body, her executioners took every precaution to ensure that her ashes would not serve any posthumous purpose-least of all the focus of a saintly cult, the possibility which is not even

9 In his report of the siege of Compiègne where Joan was captured, Chastellain was to impute a connection between Joan and another villainous cordelier, Noiroufle - "a tall black man with the face of a murderer" who "seemed" to be a man of the church ([35], II, p. 53; [36], pp. 551-52).

10 The possibility arises partly because of the derivative link that Weber makes between his concept of "charisma" and similar notions found in other cultures. Weber defined "charisma" as a "term for extraordinary powers that have been designated by such special terms as "mana'..." ([3], p. 1). In Polynesian cultures, the term "mana" has a more fluid quality that might well be expected to pass between individuals and to survive the death of its individual possessor. I am grateful to Dr Peter Meihana for illuminating clarification of this point. 
entertained. "The remains of her body were thrown in bags into the river", writes the anonymous cordelier, "so that she could never be used or employed for sorcery or any other evil" ([25], p. 83). ${ }^{11}$ The Bourgeois of Paris also mentions the "fear of enchantments" that her ashes might have been used for, but he recalled this fact in 1440 — when the threat of a resurrected Maid had suddenly arisen. "A lot was heard about the Maid nowadays" because another woman claiming to be Joan had been honourably welcomed in Orléans, and was believed to be the Maid by the people of Paris. Some thought Joan had escaped the flames because of her "sanctity" ([1], p. 354).

A sermon was preached in Paris denouncing the imposter, just as one had been preached about Joan after her burning ([1], pp. 354-55). A perception certainly existed that there were ways in which the dangerous influence of one individual might reach beyond the grave-charisma outliving its possessor. The possibility therefore also explains the response to Joan and her alias. The reactionary sermons were intended to puncture what Weber called the "pneumatic" potential of charisma. They formed part of the responses of ecclesiastical authorities to threats of prophecy and sedition, and were meant to be different in kind from the sermons of a Brother Richard. They may be usefully conceptualized in Weberian terms, as the tools of "technicians" rather than of prophets, the products of "routine" rather than "charisma".

In many respects, the response of authorities to Joan or Richard could simply be presented as the reaction of ritualized religion to the charismatic, as if the two were polar opposites. To her enemies, Joan represented the antithesis of divine order, and the sermons preached against her reasserted the order that the church wished to affirm. Just before her death at Rouen, on 30 May a sermon was preached in her presence decrying her destructive and diabolic influence on France and Christendom ([1], pp. 266-67). This day was the eve of Corpus Christi: her iniquitous behaviour was put in starker light when denounced on a feast day that stood officially for unity in Christ and liberation from the devil's thralldom ([37], pp. 215-32). Doubtless, it was a sermon preached in measured tones, without the flamboyance of a Brother Richard: churchmen at the council of Nantes in 1431, perhaps with current messianic prophets in mind, had decreed that preaching needed to be performed "with reverence and humility" and not with "horrible outcries and wild waving of hands" ([18], p. 329).

Moreover, the "routinizing" character of the sermon preached against Joan was strengthened by the context in which it was given: it was held during a "general" procession, when relics were carried to petition God for his grace. The sermon preached against her in Paris shortly after her death was also given as part of a similar procession. Frequently repeated, and drawn from an amalgam of venerable liturgical rites, ${ }^{12}$ these processions seem the quintessence of "traditionalized" religion. It appears that more of them were being launched in northern Europe by the fifteenth century than ever before: relic-carrying processions to petition for God's grace are well attested in many dioceses by the eleventh century, but a growing frequency in their use, especially in major towns, seems to have occurred from the end of the fourteenth century, in the context of

11 Weber discussed "charisma" primarily as a quality that pertained to individuals, but he lets slip the possibility that it might adhere to objects: [3], p. 1.

12 Among the liturgical precedents were the processions required on Sundays, the carrying of relics on feast days, and the litanies of Rogation ([38], pp. 27-49; [39]). 
ecclesiastical, social and political crisis. ${ }^{13}$ Urban audiences had begun to grow familiar with them. In Paris, the crises surrounding the monarchy especially after 1392, caused an increasing number of processions to be launched, often at the request of the royal court or parlement, during which sermons were preached and a large variety of relics was carried and stational churches used [40]. In the 1420 s processions became even more frequent. The metereological conditions in 1428 that seemed so portentous to the Bourgeois of Paris were countered with several processions ([44], II, pp. 278-79, 282-83, 285). The threats to Paris that continued after Joan of Arc's death also drew relics and processors from churches. At the end of 1436 when there were "murmurs and bad talk" among the people, it was decided to call general processions, according to the greffier of the Paris parlement ([44], III, p. 181). The Bourgeois testified that the most "solemn procession for 100 years" was conducted to give thanks for the grace God had bestowed on Paris for its recovery by Charles VII ([1], p. 320). Processions were still frequent in the 1440s until the English were finally vanquished: in 1441, while Charles VII was besieging Pontoise, "not a day went by ... without a procession, made either by the university, religious orders or the parishes" ([1], p. 361).

The launching of processions, patterned on venerable precedent, was the ordered reaction to crises or their aftermath. By the mid-fourteenth century, it had also become one of the responses of authorities to religious phenomena that arose outside officially accepted norms. Late medieval churchmen had been faced with many manifestations of unregulated and spontaneous piety that seemed to threaten sacramental order. The apocalyptic message of the flagellants who assembled in many towns in the wake of the Black Death was rarely welcomed by clergymen. ${ }^{14}$ Supplicatory processions with the correct liturgical procedures was the favoured response, and in places where royal and episcopal authority was particularly strong (in France, at least within the heartland of Valois power), flagellants were repulsed and more orderly processions against plague were called for ([46]; [47], II, pp. 111-12; III, p. 14). Flagellant "excess" had also been managed in other ways. At Tournai the fervour of flagellants who gathered in the city square in August 1349 and announced the Apocalypse, brought out contradictory responses: some condemned them, others approved, and for a time citizens gave up swearing and gaming (like the Parisians were to do in 1429 under Brother Richard's direction). The cathedral dean and chapter in Tournai called for processions to counter the more extravagant piety of the flagellants. In 1350, the town government prohibited further flagellant displays ([48], pp. 348-49, 354-59). Outbreaks of flagellant "excess" were less frequent by the end of the fourteenth century, ${ }^{15}$ but were still considered threatening enough to require theological rebuttal. Jean Gerson, besides being indefatigable in his efforts to heal the Schism, urge pastoral reform, and deal with spiritual discernment, was also moved to write a tract against self-flagellation (c.1417). The practices of flagellants were unauthorized, and their prediction of the apocalypse unhelpful. It was, in Gerson's opinion, better to prepare for one's own

13 Systematic study of the incidence of general processions across a wide selection of towns remains to be done, but for strong indications of a common pattern, see evidence from Paris, Orléans, several German towns, and Bruges in Flanders ([40]; [41], pp. 388-90; [42], pp. 281-328; [38], pp. 31-32, 40, 87-99, 235-46; [43], pp. 76-79).

14 Mass penitential flagellation was not new, having broken out in 1260 largely in north Italian cities [45], but its scale was greater after the Black Death.

15 For an outbreak of more sedate flagellation in 1399, see [49]. 
individual death with appropriate sacramental rites than await the arrival of the Antichrist ([50], X, pp. 40-49; [7], p. 63).

The ceremonial response to apocalyptic piety may thus be characterized as the "technicians of routine cults" asserting themselves over the "charismatic". Yet it is worth recalling that Weber did not see the one as entirely oppositional to the other. His ideal-types are not watertight categories: Weber allows seepage between them. Just as charisma could potentially outlive its individual possessor, so it could pass to the agent of official religion. Weber considered priests to hold a distinct kind of "charisma of office" ([3], p. 66), but in the performance of office, the priest could also possess some of the charisma that adhered to the prophet: "pastoral care"-and thus the preaching this involved-"stands as midway between charismatic distribution of grace and instruction" ([3], pp. 75, 161-62). The priesthood might also appropriate the ideas of prophetic movements ([3], pp. 66-67). Weber would not have agreed with Edward Shils' view that prophetic charisma could reside within institutionalized religion and the "tremendous power" it might wield ([51], esp. p. 266; [5], p. 766). Breakthroughs were unlikely to be achieved by institutions. But Weber might have conceded that an attenuated form of charisma could transfer itself to the ritualized arrangements of organized religion. ${ }^{16}$ It is in this light that the function of supplicatory processions can be usefully viewed.

On some occasions, the deployment of processions was not so much about the suppression of excessive fervour, than about its containment and appropriation. Despite the more rigid nature of their format, the processions could share in characteristics that marked out flagellant piety and messianic preaching. At Tournai in 1349, the annual procession of Our Lady on the feast day of the Exaltation of the Holy Cross (14 September), absorbed the penitential zeal of the flagellants, who processed along routes that were customary for the occasion ([48], pp. 354-59). Moreover, general processions differed from annually fixed processions or those that were required for Sundays or other feast days of obligation: they were called ad hoc, when the moment required, their scale determined by particular need. If they did not permit penitential excess, they required of their participants and audience a response that was more than formal. Tears might fill the eyes of processors. Clément de Fauquembergue, the usually laconic clerk of the Paris parlement, waxes approvingly on the "great devotion" of villagers, processing near Paris in 1428 to ward off the dire effects of the weather, who elicited such "compassion" from their spectators that "hardly anyone could watch them without tears" ([44], II, pp. 278-79). Processors might be touched by the miraculous. In April 1436, to give thanks for the entry of the royal army into Paris, the relics of two of the city's patron saints, Geneviève and Marcel, were processed: despite the miserable weather, the sodden, barefoot and exhausted processors were spared illness, in the Bourgeois' opinion, "by miracle" ([1], p. 321). Processors who followed correct procedures might yet brush with the prophetic. The Bourgeois had already discerned a divine hand at work in the "most solemn procession" called two days previously. The offertory for the holy mass for this day, he noted, spoke of praises to be given to God every year on this day: it was just as if this were a "prophecy" ([1], p. 320).

16 For Shils' interpretation of the possibility of an attenuated and dispersed charisma, based on a reading of Weber, see [51], pp. 133-34, 157. 


\section{Charisma Routinized: The Shaping of Memory}

Ceremonies like general processions were intended in the short term to draw out and harness the potential in "prophetic charisma" rather than suppress it altogether. In the long term, the charismatic - or rather memory of it - had also to be managed. The perception that the aura of an extraordinary individual might survive the grave made this more necessary. How the extraordinary was commemorated is therefore a theme that may also be framed as an aspect of the relationship between routine and charisma. Ad hoc general processions dealt with the immediate impact of extraordinary phenomena; annual and commemorative processions served to shape their memory. The divinely-worked relief of Paris, according to the Bourgeois, needed to be remembered annually. This was unproblematic: it did not need not to be attributed to the efforts of a single, extraordinary individual. The relief of Orléans, however, and the part played in it by Joan of Arc, required more careful handling. Valois caution in dealing with the Maid is well known: silence from the royal court after her capture and burning was eventually replaced by public rehabilitation of her name, at the Nullification trial in 1456, and her posthumous passage, on the back of Valois propaganda, to the status of patriotic hero and saviour of France ([11], pp. 39-46). How Joan was absorbed into civic, ecclesiastical and royal traditions, applying Weber's notion of the routine, reveals a little more about the priorities of those who shaped her memory.

Within Orléans, an annual procession to commemorate the siege began immediately. The town accounts were already recording celebration of the siege in 1431, and in 1435 the town paid for commemorative masses for the anniversary of Joan's death ([15], V, pp. 308-09). Thereafter, however, the accounts record annual payments to celebrate events on 8 May but without reference to Joan ([41], pp. 394-95). It may well be that Joan was already being fêted in other ways. In 1435 the first references appear to the staging of a play (mistère), which in 1439 (if not before) was being performed during the procession ([15], V, p. 309; [41], pp. 392-95). ${ }^{17}$ The text of Le mistere du siege d'Orleans gives full attention to Joan's heroism, but it belongs to the later fifteenth century, and probably does not reflect the play's earliest form ([52], pp. 213-21; [53], p. 16). The town accounts of the 1430s hint that other figures besides Joan were considered to merit more attention in commemoration of the siege. In 1435, they refer to the procession to the Tourelles (where the English had made their final stand). This procession carried reliquaries of the three main patron saints of the town: those of Aignan, Mamert and Euverte. These were all former bishops of ancient pedigree, and their relics had long been used for supplicatory purposes. As in Paris, an increasing number of general processions had been called in Orléans during the first three decades of the fifteenth century. Several of them reflected anxiety about the wider problems of a divided Christendom, petitioning for the unity of the Church. Others had responded to more local events. In 1427, the relics of the same three saints were processed to ask God's grace for the defence of Orléans ([41], pp. 388-90). The commemorative procession of the same relics in 1435 was an expression of gratitude for the part these saints had played in the rescue of the town: it marks the beginnings of a process whereby memory of the siege, and of Joan of Arc's place in it, was absorbed into a municipal tradition of links with the sacred.

17 Jean Thibault emphasises the way in which the annual procession came to be amalgamated with celebration of the release from captivity in 1440 of Charles, duke of Orléans ([41], pp. 394-401). 
The account of the siege produced around 1452 (itself based on earlier local accounts [52], p. 210) was also intended to establish official commemoration of the event. It appears in a manuscript before a transcription of the indulgences granted by Cardinal d'Estouteville for celebrating the day of liberation ([23], pp. 141-55; [15], V, pp. 299-301; [11], pp. 354-56). The letters of indulgence make no reference to Joan, and the account itself does not dwell exclusively on her exploits. She is introduced, part way through the account, as a sign of the "mercy of God"; in the space of a few lines, she is quickly ushered into the presence of the dauphin Charles and saddled up for battle ([23], p. 145). Her arrival at Orléans is marveled at, but her military deeds in the early days of May 1429 are recounted alongside those of others; eventually on 8 May, with other lords, she forces the English to leave the field. Her final act, in the company of churchmen (singing beautiful hymns), is to tell everyone to go to mass. Then the bishop of Orléans, with the agreement of the citizens ordered a great procession which was to bring out reliquaries from churches, particularly those of St Aignan and St Euverte, the "guardians of the town"-because "it was rumoured" that at the time of the siege, these two prelates had been seen walking around the walls of the town. The account ends with a plea for participation in this procession "with great devotion", and with a warning that points - from a Weberian perspective - to the socially normative role of such ceremony: abandoning these "saintly and devout processions", it is asserted, "would cause great strife" ([23], pp. 152-54).

The account also presents Orléans and its siege within the wider context of the kingdom of France. The siege shows the town as a bonne ville, loyal to the crown. "For such loyal service," the townsmen "were and remain in the good grace of the king who has maintained their privileges" ([23], p. 154). Memory of local victories was being absorbed into a wider pattern of commemoration ([54], pp. 137-35). At the same time, royal memory of these events was also being constructed. The Nullification trial, ending in 1456, uncovered further sources of divine aid behind Valois success at Orléans. The royally approved witnesses at the trial were less inclined to acknowledge the role played by local saints. The count of Dunois' testimony has Joan before Orléans promising the help of the King of Heaven, which would come not from her but from the prayers of Sts Louis and Charlemagne. Joan herself had a vision of these royal saints praying for the safety of king and city ([15], III, pp. 5-6).

Royal endorsement of Joan officially began with the Nullification trial. But assimilation of her memory into Valois history had required some filtering of detail about her life. Testimony at the trial rendered her unusual deeds less susceptible to criticism. Besides the gloss put on her wearing of men's clothing, her piety and chastity were placed beyond question. Justification of her acts made some concession to the imperatives of inward revelation [55], but particular stress was placed on Joan's faith in the sacraments (in ways that Jean Gerson would doubtless have applauded). The reaction of witnesses towards her proves less emotive in retrospect than it had been in earlier (and especially hostile) accounts. At her original trial in 1431, Joan was condemned as an idolator who had encouraged idolatry by allowing townspeople to kiss her hands and feet - though according to her own testimony she had allowed people to do this as little as she could ([15], I, p. 102). At the Nullification trial, much less is reported about the manner in which she was received into towns, and one witness declared that Joan had been heard berating those who had kissed her like an idol ([15], IV, p. 84). The effect of such testimony was to make Joan a less extraordinary figure and 
more suitable for official commemoration. The sentence of Nullification on 7 July 1456 was followed by another general procession and a public sermon that called for the erection of a cross “in her perpetual memory" ([15], IV, p. 361).

The imprimatur of royal approval allowed greater scope to be given to Joan's exploits in later and more localised accounts. ${ }^{18}$ The chronicle written in 1467 (Le petit traite par maniere de chronique) ([23], pp. 1-131) places the siege of Orléans within the wider story of Charles VII's march to Rheims, but does dwell in detail on Joan's military successes. Final victory at Orléans, however, was attributed to the miraculous intervention of the former bishops of the town and to the devotional behaviour of its citizens. The assault on the Tourelles was made "at the request of St Aignan and St Euverte": an eye-witness attested that for him and for the Englishmen inside the Tourelles, it seemed that the attack was made by "an astonishing number of people, as if the whole world was assembled there". For this all the clergy and people of Orléans "very devoutly" sang Te Deum laudamus and had all the city bells rung to thank God and the two saint-confessors for this divine comfort ([23], p. 88). Victory was therefore assured when Joan of Arc sallied forth the following day. On 9 and 10 May "very fine and solemn processions" were held by everyone in the town who visited churches with "great devotion" ([23], p. 92).

The text for the Mistere du siege d'Orleans must be set in the context of the celebratory nostalgia that was generated around the victorious Charles VII in the later fifteenth century ([56], p. 274; [54], pp. 137-51; [53], p. 16). Joan is certainly central to the drama of the play: it is her unique links with saintly intercessors that bring help to Orléans and Charles. But her heroic actions are enclosed within a narrative commemorating events that showed divine favour to town and king. Her first appearance, half way through the play, follows Charles' own prayers to heaven for help. St Aignan and St Euverte intercede with God to send protection for the town, though they are now ably assisted by St Michael whose support of the royal cause had long been acknowledged ([53], fos. 167r-77r; [54], pp. 152-60). The two local saints duly appear on the ramparts on Ascension day to rally the citizens. On the Sunday following final victory Joan herself urges commemoration of the event: "Si faictes memoire a toujours / de ceste belle delivrance" ([53], fos. 361v-62r). Upon her last return to Orléans at the end of the play, the liturgical nature of this commemoration is made clearer: she urges the citizens not once but three times to "faire processions" in praise of God and the Virgin Mary ([53], fos. 508v-9r).

Memory of Joan was shaped to suit official civic, ecclesiastical and royal needs. Uncomfortable aspects of her extraordinary acts were tidied away, and commemoration of her aligned with more conventional patterns of devotional behaviour. Her attachment to sacrament and liturgy was repeatedly emphasized. "Routine" superseded "charisma" - and so it was that Joan's associations with the "charismatic" prophet were quietly forgotten. Memory of her links with Brother Richard was made to fade. Despite his popularity at Orléans during Lent of 1430, Richard is accorded no mention in the account of the siege c.1452, nor in the many folios of the mistere. At the Nullification trial, he appears only to be discounted as insignificant. One witness saw him acting as Joan's confessor before the town of Senlis ([15], II, p. 450). More than one witness report on her

18 Vicky Hamblin argues that the greater role given Joan in these accounts was also the result of concession to "public opinion" and approval of the Maid: [52], pp. 220-21. 
associations not with itinerant preachers but with mendicants securely stationed in the friaries of the towns she visited ([15], IV, pp. 14, 101, 104).

The charisma of a Brother Richard was a little too dangerous to be recalled with comfort. Like others of his ilk, he could be welcomed into towns. But municipal authorities preferred more organized access to divine grace: in the same year (1430) that the town council of Orléans funded Brother Richard to preach, it paid for eight sermons from other local mendicants and for twelve processions ([23], pp. 233-54). Other secular authorities might heed prophetic warnings, but would not listen equably for long to predictions of imminent apocalypse - and its inevitable leveling of all social hierarchy. Brother Richard may have been a fervent supporter of the Valois cause, but kings preferred to recall preachers whose prophecies had predicted the resurrection of the monarchy rather than birth of the Antichrist. ${ }^{19}$ Churchmen might still listen to those who claimed direct links with saintly and divine figures, but with mounting suspicion ([57], pp. 297-303). By the time of the Nullification trial in 1456, Joan's own associations with the prophetic were made to take on a more acceptable form. Reports of Brother Richard's prediction of "wonders" to come and his announcement of the divine secrets to which Joan was privy, are replaced in favour of prophecies from more suitable sources. At the trial, Jean Barbin, royal advocate in the parlement in Paris, recollected that Master Jean Erault, one of Joan's interrogators at Rouen, had "firmly believed" that Joan's advent had been prophesied by Marie Robine. Marie had appeared before the pope at Avignon, where she had lived as a recluse, and later at the French royal court in 1398, in order to reveal her visions about the ending of the Papal Schism. Jean Barbin does not report the more calamitous revelations that Marie, after her departure from court, claimed would befall France for failure to heal the Schism, but instead recalls a prediction that escapes all mention in her known revelations - that a "puella" would come to deliver the kingdom from the enemy ([15], III, pp. 83-84; [28], pp. 280-82). With a little finessing, Marie Robine was a safer source of prophecy for Joan's arrival than Brother Richard.

19 One example of a mendicant visionary who fared better in royal memory is the hermit Jean de Gand (who was eventually interred in the Dominican friary at Troyes in 1439). He had appeared before the dauphin Charles in 1421 (after a fruitless appeal to Henry V) and promised the eventual success of Valois arms against the English. In 1482 Louis XI petitioned for his canonization, following a pilgrimage to his shrine and cure from apoplexy ([58]; [59], pp. 22-34). 


\section{Conclusions}

Joan of Arc will always command more attention that Brother Richard. Her life was more remarkable, her death more appalling, and thus more productive of debate. On the one hand, her eventual canonization in 1920 (as a virgin rather than martyr), and her role as patriotic hero in two world wars, represent the final apotheosis of Valois restoration of her name. On the other hand, modern interest in the history of gender has served to sharpen interest in her fate and other aspects of its significance ([11], pp. 46-59). For Dyan Elliot, the patriarchal treatment of her visions and those of other females, notwithstanding the Nullification trial, represents a negative shift in attitudes to women: "[t]he lost possibility of Joan's ... spirituality coincides with the first stages of a more pervasive effacement of Europe's faith in positive female spirituality" ([57], p. 296). If so, it is ironic that memory of Joan, and prodigious production of controversy about her, has tended simultaneously to efface the memory of a male prophet whose immediate impact was more alarming to those in authority. Weber's concepts of "charisma" and "routinization" serve to reconstitute the significance of Brother Richard in the eyes of his contemporaries. They also serve to draw attention to the forces that sought to contain his influence. The processes that shaped the fate of Joan of Arc, in life and in the half century after her death, especially in ceremony and other forms of commemoration, were equally influential on the fate of Brother Richard. Joan was more controversial because she crossed accepted gender roles. But Richard was more "charismatic", in Weber's sense of the term, and therefore more dangerous. Memory of his life had to be dealt with differently. The controversial nature of Joan's behaviour generated debate but ultimately the consequences of it did not have to be viewed as a reversal of social order. She could be discussed, interrogated and, with varying degrees of misogyny, mounted on pedestal or consigned to pyre. Brother Richard's apocalyptic message had been altogether more threatening. It may have seemed less so with the passage of time: after all, the Antichrist declined to appear in 1429. Yet there was no room for memory of the friar's preaching following the re-establishment of Valois power in France. Richard's charisma was to be granted no afterlife: his influence was best forgotten, at least by those who wished Joan's memory to be detached from any hint of eschatology and social upheaval.

Brother Richard was not quite erased from all chronicles associated with the Valois cause. Some even permit him a prophetic voice, but significantly one that softens his charismatic impact. In Le petit traite (1467), he appears briefly in the account of the siege of Troyes in late June 1429 at a time of crisis for the royal army: soldiers were suffering from hunger, and would have died but for a sudden abundance of fresh beans. These had been planted in the previous year at the urging of Brother Richard, "who from Advent to Christmas and before had preached in many places in the pays of France". He had preached "other things in his sermon". What these were, the chronicler chooses not to say, and instead restricts himself to just one of Brother Richard's utterances: "Sow, good people, sow beans aplenty, for this will bring good things soon" ([23], pp. 109-10). ${ }^{20}$ A prescient and valuable warning no doubt, but a shade less momentous than prediction of the Apocalypse.

20 The story of Richard's "marvellous" production of beans is also told in the chronicle attributed to Guillaume Cousinot ([60], p. 315). 


\section{Acknowledgments}

I am very grateful to Gary Dickson for his help in revising drafts of this article.

\section{References}

1. Alexandre Tuetey, ed. Journal d'un bourgeois de Paris 1405-1449. Paris: H. Champion, 1881.

2. Sophie Oosterwijk. "Of Dead Kings, Dukes and Constables: The Historical Context of the Danse Macabre in Late Medieval Paris." Journal of the British Archaeological Association 161 (2008): 131-62.

3. Max Weber. The Sociology of Religion, translated by Ephraim Fischoff, introduction by Talcott Parsons. London: Methuen, 1965.

4. Max Weber. The Theory of Social and Economic Organization, translated and edited by A.M. Henderson and Talcott Parsons. New York: Free Press of Glencoe, 1947.

5. Gary Dickson. "Charisma, Medieval and Modern.” Religions 3 (2012): 763-89.

6. S. Luce. Jeanne d'Arc à Domremy: recherches critiques sur les origines de la mission de la Pucelle. Paris: Librairie Hachette, 1886.

7. Jules de la Martinière. "Frère Richard et Jeanne d'Arc à Orléans, mars-juillet 1430." Moyen âge $3^{\text {rd }}$ series 5 (1934): 189-98.

8. Étienne Delaruelle. 'L'Antéchrist chez saint Vincent Ferrier, saint Bernadin de Sienne et autour Jeanne d'Arc.” In La piété populaire au Moyen Age. Torino: Bottega d'Erasmo, 1975, 329-54.

9. Étienne Delaruelle. "La spiritualité de Jeanne d'Arc." In La piété populaire au Moyen Age. Torino: Bottega d'Erasmo, 1975, 355-400.

10. André Vauchez. 'Une 'sainte femme' du Val-de-Loire a l'époque de la guerre de cent ans: Jeanne-Marie de Maillé (1331-1414).” In Les laïcs au Moyen Age. Paris: Cerf: 1987, 225-36.

11. Craig Taylor. Joan of Arc. La Pucelle. Manchester: Manchester University Press, 2006.

12. Anne Llewellyn Barstow. "Joan of Arc and Female Mysticism." Journal of Feminist Studies in Religion 1 (1985): 29-42.

13. James Fentress, and Chris Wickham. Social Memory. Oxford: Blackwell, 1992.

14. David L. d'Avray. Medieval Religious Rationalities: A Weberian Analysis. Cambridge: Cambridge University Press, 2010.

15. Jules Quicherat. Procès de condamnation et de réhabilitation de Jeanne d'Arc dite la Pucelle. Paris: Libraires de la société de l'histoire de France, 1841-49, 5 vols.

16. Hervé Martin. Les ordres mendiants en Bretagne, vers 1230-vers 1520: pauvreté volontaire et prédication à la fin du Moyen Âge. Paris: C. Klincksieck, 1975.

17. Gary Dickson. "Encounters in Medieval Revivalism: Monks, Friars, and Popular Enthusiasm." Church History 68 (1999): 265-93.

18. Hervé Martin. Le métier de prédicateur en France septentrionale à la fin du Moyen Âge (1350-1520). Paris: Cerf, 1988.

19. Alberto Ferreiro. "Vincent Ferrer's 'Beati Petri Apostoli': Canonical and Apocryphal Sources in Popular Vernacular Preaching." The Harvard Theological Review 91 (1998): 41-57. 
20. Dyan Elliott. "Seeing Double: Jean Gerson, the Discernment of Spirits, and Joan of Arc." American Historical Review 107 (2002): 26-54.

21. L. Douët-d'Arcq, ed. La chronique d'Enguerran de Monstrelet, 1400-1444. Paris: Société de l'histoire de France, 1857-1862, 6 vols.

22. Ram Ben-Shalom. "A Minority Look at the Mendicants: Isaac Nathan the Jew and Thomas Connecte the Carmelite." Journal of Medieval History 30 (2004): 213-43.

23. Paul Charpentier, and Charles Cuissard. Journal du siège d'Orléans 1428-1429. Augmenté de plusieurs documents notamment des comptes de ville 1429-1431. Orléans: H. Herculson, 1896.

24. Jules Quicherat. "Relation inédite sur Jeanne d'Arc." Revue historique 4 (1877): 329-444.

25. Jules Quicherat. "Supplément aux témoignages contemporains sur Jeanne d'Arc et la chronique des cordeliers de Paris." Revue historique 19 (1882): 60-83.

26. Michael D. Bailey. "From Sorcery to Witchcraft: Clerical Conceptions of Magic in the Later Middle Ages." Speculum 76 (2001): 960-90.

27. André Vauchez. "La sainteté mystique en occident au temps des papes d'Avignon et du Grand Schisme.” In Les laïcs au Moyen Age. Paris: Cerf, 1987, 251-57.

28. André Vauchez. "Jeanne d'Arc et le prophétisme féminin des $\mathrm{XIV}^{\mathrm{e}}$ et $\mathrm{XV}^{\mathrm{e}}$ siècles." In Les laïcs au Moyen Age. Paris: Cerf, 1987, 277-86.

29. Nadia Margiolis. "The Mortal Body as Divine Proof: A Spiritual-Physical Blazon of Joan of Arc." Joan of Arc and Spirituality, edited by Ann W. Astell, and Bonnie Wheeler. Basingstoke: Palgrave Macmillan, 2008, 9-36.

30. Beverley M. Kienzle. "Crisis and Charismatic Authority in Hildegard of Bingen's Preaching Against the Cathars." In Charisma and Religious Authority. Jewish, Christian, and Muslim Preaching, 1200-1500, edited by Katherine L. Jansen, and Miri Rubin. Turnhout: Brepols, 2010, 73-91.

31. Renate Blumenfeld-Kosinski. Poets, Saints, and Visionaries of the Great Schism 1378-1417. University Park: Penn State University Press, 2006.

32. Lynn Staley, ed. The Book of Margery Kempe. Kalamazoo: Medieval Institute Publications, 1996.

33. Élisabeth Lopez. Culture et sainteté. Colette de Corbie (1381-1447). Saint-Etienne: Publications de l'université de Saint-Etienne, 1994.

34. Gabriella Zarri. "Places and Gestures of Women's Preaching in Quattro- and Quincento Italy." In Charisma and Religious Authority. Jewish, Christian, and Muslim Preaching, 1200-1500, edited by Katherine L. Jansen, and Miri Rubin. Turnhout: Brepols, 2010, 177-93.

35. Georges Chastellain. Oeuvres de Georges Chastellain, edited by M. Kervyn de Lettenhove. Brussels: Académie Royale de Belgique, 1864, 8 vols.

36. Estelle Doudet. "La condicion de l'hystoriographe: enquête sur une figure et un statut dans l'oeuvre de George Chastelain." Le Moyen Age 112 (2006): 545-56.

37. Miri Rubin. Corpus Christi. The Eucharist in Late Medieval Culture. Cambridge: Cambridge University Press, 1991.

38. Andrea Löther. Prozessionen in Spätmittelalterliche Städten. Cologne: Böhlau, 1999.

39. André Vauchez. "Liturgie et culture folklorique: les Rogations dans la 'Légende Dorée' de Jacques de Voragine.” In Les laïcs au Moyen Age. Paris: Cerf, 1987, 145-55. 
40. Jacques Chiffoleau. "Les processions parisiennes de 1412. Analyse d'un rituel flamboyant." Revue historique 114 (1990): 37-76.

41. Jean Thibault. "Fête et renouveau de la vie sociale à Orléans après 1429." Le Moyen Age 116 (2010): 385-406.

42. Gabriele Signori. "Ritual und Ereignis. Die Straßburger Bittgänge zur Zeit der Burgunderkriege (1474-1477).” Historische Zeitschrift 264 (1997): 281-328.

43. Andrew Brown. Civic Ceremony and Religion in Medieval Bruges c.1300-1520. Cambridge: Cambridge University Press, 2011.

44. Journal de Clément de Fauquembergue, greffier du Parlement de Paris, edited by Alexandre Tuetey. Paris: Libraire Renouard, 1903, 3 vols.

45. Gary Dickson. "The flagellants of 1260 and the Crusades." The Journal of Medieval History 15 (1989): 227-67.

46. Étienne Delaruelle. "Les grands processions de pénitents de 1349 et 1399." In La piété populaire au Moyen Age. Torino: Bottega d'Erasmo, 1975, 280-313.

47. Paul F. Fredericq, ed. Corpus documentorum inquisitionis haereticae pravitatis Neerlandicae. Gent: Vuylsteke, 1906, 3 vols.

48. Gillis li Muisis. Chronica Aegidii li Muisis. In Collection de Chronique Belges inédites, II, edited by J. -J. de Smet. Brussels: Commission royale d'histoire, 1841.

49. Daniel E. Bornstein. The Bianchi of 1399. Popular Devotion in Late Medieval Italy. Ithaca: Cornell University Press, 1993.

50. Jean Gerson. Oeuvres complètes de Jean Gerson, edited by P. Glorieux. Paris: Desclée, 1960-73, 10 vols.

51. Edward Shils. Center and Periphery. Essays in Macrosociology. Chicago: University of Chicago Press, 1975.

52. Vicki L. Hamblin. "En l'honneur de la Pucelle: Ritualizing Joan the Maid in Fifteenth-Century Orléans." In Joan of Arc and Spirituality, edited by Ann W. Astell, and Bonnie Wheeler. Basingstoke: Palgrave Macmillan, 2008, 209-26.

53. Vicki L. Hamblin. Le mistere du siege d'Orleans. Geneva: Libraire Droz, 2002.

54. Colette Beaune. The Birth of an Ideology. Myths and Symbols of Nation in Late-Medieval France, translated by Susan R. Huston, edited by Frederic L. Cheyette. Berkeley: University of California Press, 1991.

55. Jane Marie Pinzino. "Joan of Arc and Lex Privata: A Spirit of Freedom in the Law." In Joan of Arc and Spirituality, edited by Ann W. Astell, and Bonnie Wheeler. Basingstoke: Palgrave Macmillan, 2008, 85-109.

56. Colette Beaune. "L'historiographie de Charles VII: un thème de l'opposition à Louis XI." In La France de la fin du XVe siècle. Renouveau et apogée, edited by Bernard Chevalier and Philippe Contamine. Paris: Centre national de la rechereche scientifique, 1985, 265-82.

57. Dyan Elliott. Proving Woman. Female Spirituality and Inquisitional Culture in the Later Middle Ages. Princeton: Princeton University Press, 2004.

58. Colette Beaune. "Jean de Gand, prophète et bienheureux." In Prophètes et prophéties. Paris: Presses de l'école normale supérieure, 2003, 14-30. 
59. Victor de Buck. Le bienheureux Jean de Gand dit l'ermite de Sainte-Claude, précurseur de Jeanne d'Arc. Brussels: Revue Belge et Étrangère, 1862.

60. Guillaume Cousinot. Chronique de la Pucelle attribuée à Guillaume Cousinot. Reimpression de l'edition de Vallet de Viriville. Preface by Françoise Michaud-Fréjaville. Caen: Paradigme, 1992. 
Reprinted from Religions. Cite as: Bezio, K.M.S. "Drama \& Demigods: Kingship and Charisma in Shakespeare's England." Religions 4 (2013): 30-50.

\title{
Drama \& Demigods: Kingship and Charisma in Shakespeare's England
}

\author{
Kristin M. S. Bezio
}

\begin{abstract}
Shakespearean charisma, with its medieval roots in both religion and politics, served as a precursor to Max Weber's later understanding of the term. The on-stage portrayal of charismatic kingship in the twilight of the Tudor dynasty was not coincidental; facing the imminent death of a queen, the English nation was concerned about the future of the monarchy. Through the depiction of the production and deterioration of royal charisma, Shakespeare presents the anxiety of a population aware of the latent dangers of charismatic authority; while Elizabeth managed to perpetuate an unprecedented degree of long-term charismatic rule, there could be no certainty that her successor would be similarly capable. Shakespeare's second tetralogy-known as the Henriad - examines this royal charisma as it appears both under crisis and in the process of what Weber would later characterize as routinization. While Henry IV (Bolingbroke) originally makes use of charisma to ensure his succession to Richard II's throne, he loses his charismatic authority in the process. Henry V, by contrast, makes use of deliberate crisis - his claim to the French crownin order to restore royal charisma. Henry V's success, however, cannot last, and his son's reign is a disastrous reminder that charisma is, as Weber will later argue, inherently unstable.
\end{abstract}

\section{Abbreviations}

R2: Richard II; 1H4: 1 Henry IV; 2H4: 2 Henry IV; H5: Henry V.

\section{Introduction}

During the first decades of William Shakespeare's dramatic career, England confronted an impending monarchical crisis as the aging Queen Elizabeth I refused to designate an heir. Compounding the national anxiety surrounding this dilemma was an ongoing debate about kingship and the rising prominence of claims of divine right, both in England and abroad. The Elizabethan problem of succession brought to the fore the problematic nature of a monarchy reliant upon both traditional means of succession and personal charisma. Facing the possibility of an interregnum, the machinery of the English government sought to establish an institution capable of steering the nation in the absence of a monarch. However, these attempts at institutionalization on 
the part of Parliament and the Privy Council met with resistance, as Elizabeth was unwilling to give up her claims to both traditional and personal charismatic authority. The consequent tension between queen, Council, and Parliament exacerbated an already ongoing ideological debate on the definition of kingship and the role of royal charisma that spilled over from the political and into the popular and cultural spheres.

Shakespeare, as the servant of a powerful courtly magnate, but-more importantly_also as a playwright, was positioned not only to comment upon, but also to be able to publically disseminate the debate concerning changing conceptions of charismatic sovereignty. Shakespeare's Henriad (Richard II, 1 and 2 Henry IV, Henry V), which appeared on the London stages from 1595-1599, explores the inadequacy of the Continental understanding of royal charisma as divinely endowed, foregrounding instead the need for an institutional separation between the charisma of the sovereign office and the personal charisma of the individual monarch. The tetralogy's conclusion, drawing from a medieval tradition of limited monarchy, exposes the Continental vision of divine right charisma as inherently unstable, instead advocating for an institutional separation of monarch and office as the only viable solution to the Elizabethan succession crisis.

\section{The Origins of Shakespeare's Charisma}

Charisma as a concept, as has often been noted by scholarship, originates in early Christianity with Saint Paul, and means "gift of grace" [1-3]. Although Weber is often credited with translating the term from theology to sociology, the application of the theological term to the study of medieval and early modern monarchy is explicitly relevant to understanding the function and role of kings. As medieval and early modern scholars and theorists understood it, "kingship," explains historian Henry Allen Myers, "is both the rule of one person over a political unit, as at least its nominal head, and the art or science by which such a ruler governs well," which, Myers continues, lies in the possession of "a certain mystique or charisma," meant both in a modern sense of personality and the purely theological sense of divine grace [4]. In essence, the practice of kingship reflected a dual belief in the sanctity of the monarch, as well as in the monarch's obligation to meet the expectations of martial heroism, sanctified piety and wise judgment that comprised the sovereign ideal. For most of medieval Europe, "kingship" was synonymous with "divine right" and "absolutism," a paradigm in which such "mystique" was the specific endowment of God. However, there existed a competing theory, which argued that sovereign grace required the ratification of the subjects, referred to by J.P. Sommerville as "designation" [5]. In divine right theory, the "act or practice" of rule became secondary to grace, while in designation theory, practice was the means by which the king demonstrated the possession of grace.

The theories of kingship that prevailed during Shakespeare's lifetime both in England and on the Continent were predicated on medieval theology, as well as practical and military prowess. Yet, despite these universal conceptual origins, philosophers, authors, politicians and even monarchs themselves could not agree on the components of proper kingship beyond the dual elements of spiritual sanctity and political might. The early medieval origins of these two aspects - and their different applications in England and on the Continent - help to illuminate the impetus behind early modern theorists' and playwrights' frequent focus on medieval kings. 
The spiritual side of monarchical duality originates in the Germanic concept of Heil, which is most often misleadingly translated as "luck" or "fortune." The term's Norse derivation provides us with a more accurate definition, as Bettina Sejbjerg Sommer explains: "Heill is used synonymously with goefa/gipta" in the Norse language, meaning "a force internal to the man," although, she continues, these terms "are never used to express an external manifestation. They may be sent forth from the owner himself to help others. Both derive from gipt [gift], which points toward a concept of luck as something granted from some higher power" [6]. Furthermore, this understanding of "luck" differed significantly from its later definition as "good fortune" or "chance"; rather, "luck was a quality inherent in the man and his lineage, a part of his personality similar to his strength, intelligence, or skill with weapons, at once both the cause and the expression of the success, wealth, and power of a family." Heil, etymologically speaking, is synonymous with Saint Peter's use of the term "charisma" as applied explicitly to monarchs. Essentially, the Norse-Germanic Heil would evolve into the sense of divine endowment articulated in the medieval and early modern understandings of divine right kingship.

As Europe became Christianized, Heil was co-opted into the Christian redefinition of kingship as inclusive of religious piety, the theological underpinnings of divine right. As medieval Christianity spread, it restructured tribal and warlord monarchies, fusing together the spiritual elements of Heil with the martial prowess of warlord rulership needed to defend a population from external threat. Christian practices of leadership, with their roots in "the Near East background of the Judaic-Christian tradition," defined kingship "in ethnic, religious, and charismatic terms," states Myers. Specifically, early medieval Christian theories of monarchy drew upon the Davidic example, which laid specific claim to direct endowment of royal authority by God. Assertions of Davidic authorization frequently accompanied claims of absolute sovereignty leading well into the seventeenth century, as in James VI of Scotland's (1598) The Trew Law of Free Monarchies, in which he propounds that "Kings are called Gods by the propheticall King Dauid, because they sit vpon GoD his Throne in the earth" [7].

The belief that Christ descended from the lineage of David reconfirmed the theological contention that kings were semi-divine, and the link to Christ gave rise to claims of the ability of monarchs to perform miraculous healings; in essence, "Kings were not only supposed to have better physical constitutions than others, manifested by longevity and the fact that their wounds healed more quickly than those of ordinary men, but they were also expected to be able to impart health and healing." Ernst Kantorowicz advocates that this link between Christ and kings produced the concept of the king's two bodies. He cites Christ's persona mixta-mixed spiritual and physiological existence - as the precursor to the monarchical dual bodies as personae geminatae or "human by nature and divine by grace" [8]. Yet, while this duality was adopted by the medieval Church in the distinction between the corpus verum (the host and the physical body of Christ) and the corpus mysticum (the spiritual body of the Church), according to more recent scholarship, the duality of the monarchy, especially as it developed in England, appears in fact not to be predicated on Christology [9-14]. Instead, the duality of royal charisma springs from the originally distinct roles of medieval monarchs as either spiritual or martial leaders, related to Davidic kingship, but distinct from Christological sanctity. 
Although kingship was first and foremost a legal rather than religious office, the fusion of spiritual and martial elements elevated the monarch to a singular and superior position, firmly locating sovereign power in the specific person and body of the king, what Weber terms "traditional authority" [15]. The traditional authority of medieval kingship was therefore also charismatic by virtue of its reliance on both Heil and heroism: "In the case of charismatic authority, it is the charismatically qualified leader as such who is obeyed by virtue of personal trust in his revelation, his heroism or his exemplary qualities so far as they fall within the scope of the individual's belief in his charisma." In essence, Weber explains, "Kingship originates in charismatic heroism."

The early medieval concept of royal charisma arose from the conjunction of Heil and heroism, and the evolution of divine right theory-perhaps the most promoted theory of sovereignty in Shakespeare's day - was the natural consequence. Weber explains the relationship in terms of the king's ability to use martial and spiritual success to his followers' benefit: "If proof and success elude the leader for long, if he appears deserted by his god or his magical or heroic powers, above all, if his leadership fails to benefit his followers, it is likely that his charismatic authority will disappear. This is the genuine meaning of the divine right of kings (Gottesgnadentum)." However, as divine right evolved, it marginalized the followers in favor of the king, precluding rebellion as a sin against God-qua-king. By virtue of his Heil, the king became a demigod, infallible and untouchable, supported in his reign by a mythic tradition that placed him on a plane above his subjects [16].

In traditionalist regimes, charisma is often treated as an inheritable quality, capable of being passed through bloodlines. Primogeniture - what Weber refers to as "paternalism"- thus became the primary means of transference for traditional charismatic authority throughout most of medieval Europe; Weber notes that in this process, the original understanding of divine right as reliant on the followers "is fundamentally altered and now comes to mean authority by virtue of personal right which is not dependent on the recognition of those subject to authority." However, although this scenario played out in Continental Europe, medieval England persisted in adhering to an earlier understanding of royal charisma in which popular designation - the ratification of the monarch by the people, whether through active election or passive acceptance-remained a necessary component of divine authorization.

England, unlike the vast majority of Europe, retained the ideological basis of Anglo-Saxon participatory governance despite repeated conquests by Rome and other Continental powers, as, even into the fifteenth and sixteenth centuries when divine right was popular on significant portions of the Continent, England remained firmly entrenched in participatory limited monarchy $[17,18]$. This ideology produced the Magna Carta in the thirteenth century, the formation of an official Parliament in the fourteenth and the legal deposition of multiple monarchs (Edward II, Richard II, Henry VI) in the century leading up to the Wars of the Roses [19-21]. English reliance on participatory rather than traditional charismatic authority meant that English political ideology was profoundly resistant to claims of charismatic divine right; this resistance, in turn, produced the atmosphere necessary for the redefinition of monarchy as an institutionalized bureaucracy rather than a cult of personality. In essence, England was ideologically prepared to reject divine right in favor of "routinized" charismatic authority. 


\section{Elizabethan Royal Charisma and the Succession Crisis}

By the time Shakespeare wrote for the London stages, Continental theories of divine right were being promoted and disseminated in England, producing an ideological debate between traditional English limited monarchy and the absolutism imported by Henry VII. The circumstances of Henry VII's accession-victory over Richard III at the Battle of Bosworth Field - enabled subsequent Tudor claims of traditional charismatic authority based on conquest, what Garry Wills terms "founding" kingship [22]. Henry VII assumed the throne through "charismatic war leadership that has become permanent," and passed down his dynastic line to Elizabeth through a combination of primogeniture and royal designation. ${ }^{1}$

By the closing decade of the sixteenth century, Tudor England had seen repeated monarchical crises: the death of Henry VII's eldest son, Arthur; Henry VIII's six wives; the death of the minor King Edward VI; the short but bloody reign of Mary I; and the four-decades'-long rule of an unmarried and childless queen. By 1595, when Shakespeare's Henriad opened on the stage of The Theatre, the nation was largely disillusioned with the Tudor dynasty's promotion of divine right. Although Elizabeth's use of pageantry and public appearance helped to secure her position as unquestioned queen, her refusal to either marry or name an heir was a significant cause of national anxiety. These circumstances bear out Weber's later observation that "Charismatic authority is inherently unstable," a situation also recognized by both playwrights, like Shakespeare, and by the courtiers and councilors who were positioned to influence succession and national stability.

As a monarch, Elizabeth was uniquely capable of exploiting both divine right and the English understanding of designatory limited monarchy to her best advantage. Drawing on her lineal descent from Henry VII as a founding charismatic king and her designation as heir by her father, Henry VIII, Elizabeth was able to claim charismatic authority on multiple levels. Her Tudor lineage authorized her through traditionally charismatic paternalism and her active engagement in the cultivation of rhetoric, image and vision in the face of multiple national crises-most obviously, the English success over the Spanish Armada, allegorized in the circa 1588 Armada Portrait by George Gower - confirmed her individual heroic charisma [24]. Elizabeth, in other words, embodied royal charisma as the fusion of metaphysical Heil and practical monarchical heroism.

Yet despite this success, Elizabeth's rule suffered from the inability to designate an appropriate successor, a circumstance characteristic of charismatics, as Jay Conger explains: "charismatic leaders often have a difficult time developing successors. They enjoy the 'center stage' too much to share it. To find a replacement who is a peer may be too threatening for leaders who tend to be so narcissistic" [25]. While "narcissism" may have played a part in Elizabeth's refusal to name an heir, fear for her own personal security and for the security of the realm made up significantly more of her rationale, as seen in a speech given to a joint delegation of the Houses of Lords and Commons on November 5, 1566: "Your petition is to deal in the limitation of the succession. At this present, it is not convenient, nor never shall be without some peril unto you and certain danger unto me" [26]. William Cecil's report to the full House of Commons the next day acknowledges Elizabeth's concerns,

\footnotetext{
Henry VIII, Henry VII's son, succeeded to the throne through primogeniture. However, in the 1534 Act of Succession, Henry stipulated the subsequent line of inheritance, in accordance with Weber's suggestion that a charismatic heir can be designated by the previous holder [23].
} 
but also emphasizes the instability produced by her royal charismatic rule: "For she said she knew any causes and some of her own experience, having been a second person to a sister (the late queen meant) how perilous it was for her own person. But yet if she did not also see how perilous it was for her subjects at this time, she would not forbear for her own peril to deal therein" [27]. Both Elizabeth and her Council were aware of the difficulty in naming an heir in terms of both personal and national security, but the nation at large was also concerned with both the transition of power and the person who would next assume the throne.

\section{Shakespeare's Henriad and Royal Charisma}

The topic of succession appeared frequently in pamphlets, poems and on stages and dramatic scaffolds throughout England, expressing deep anxiety not only about the process of succession, but also about the character and identity of the person who would assume Elizabeth's power. Drama in the 1580s and 1590s was almost obsessive in its depiction of failed monarchs, usurpers and regicides. Shakespeare's second tetralogy was immediately concerned with the process of non-dynastic succession and the different manifestations of royal charisma. The first and last plays in the Henriad, in particular, demonstrate this preoccupation with the contrast between primogeniture and performative designation - the former of which would cease to be a determinant of succession with Elizabeth's death. The opening play in the sequence, Richard II (1595), presents a contrast between Richard, as king by virtue of traditional charisma, and Henry Bolingbroke, whose individual charismatic appeal allows him to overthrow Richard. Historical (quasi-)accuracy aside, Shakespeare's choice to depict in two figures the two facets of royal charisma (Heil and heroism) reveals his awareness of an ideological shift in the conception of monarchical legitimacy from paternalistic to designatory and, more importantly, the consequent rise in institutional over personal charisma.

In the play, Richard very clearly stands as the figure of the divine right monarch. Faced with rebellion upon his return from Ireland, Richard asserts that Heaven itself will defend his dynastic right to the crown:

For every man that Bolingbroke hath pressed

To lift shrewd steel against our golden crown,

God for His Richard hath in heavenly pay

A glorious angel. Then, if angels fight,

Weak men must fall, for heaven still guards the right. (R2 3.2.58-62) [28]

The "right" to which Richard refers is that conferred upon him by his lineage- traditional charisma qua divine right. Yet his "sacred blood" ( $R 2$ 1.2.12) is insufficient to defend his throne when placed in opposition to Bolingbroke's individual heroic charisma.

By contrast, Bolingbroke-banished by Richard in the early acts of the play-evinces a more modern charismatic relationship to his (formerly Richard's) followers. Richard describes Bolingbroke's departure from England, in which he appears more as a popular charismatic than a banished criminal: 
Ourself and Bushy, Bagot here and Green

Observed his courtship to the common people-

How he did seem to dive into their hearts

With humble and familiar courtesy,

What reverence he did throw away on slaves,

Wooing poor craftsmen with the craft of smiles

And patient underbearing of his fortune,

As 'twere to banish their affects with him.

Off goes his bonnet to an oyster-wench.

A brace of draymen bid God speed him well,

And had the tribute of his supple knee

With 'Thanks, my countrymen, my loving friends',

As were our England in reversion his,

And he our subjects' next degree in hope. (R2 1.4.23-36)

As Cajsa Baldini remarks, "Bolingbroke does not... have any difficulties gaining the love of the people and his friends. He is easy-going and dashing, which has earned him the love of the masses," a sentiment echoed by many critics, including Aaron Landau, who observes that Bolingbroke's "nationalist stance is thus also to a large extent a provocatively popular one, in addition to, or irrespective of, the 'original' political intention behind such populism" [29,30]. Rather than confirming Richard's power by accepting his banishment with humility, Bolingbroke adopts the persona of a kingly rival as he takes his leave of England, establishing himself as a claimant for the throne and revealing Richard's inadequacies. While Richard terms his people "slaves," Bolingbroke acknowledges the power held by the commons to ratify their monarch as “our subjects' next degree in hope.” In essence, Bolingbroke's personal charisma is authorized by his followers rather than by primogeniture.

Situated within its Elizabethan context, this comparison raises significant questions about both royal designation (by monarchical will) and inheritance as the means of transferring charismatic authority. The simple fact that Bolingbroke functionally designates himself_-although he does follow the letter, if not the spirit, of the law by coercing Richard into naming him as heir-problematizes both primogeniture and royal designation. In order to assume the throne, Bolingbroke must convince Richard to willingly cede the throne, yielding a linguistic and literal tug-of-war over the crown. Eventually, Richard concedes, but, following Richard's deposition, Bolingbroke-now Henry IV - faces the problem of having been, like Elizabeth, a "second person" who now himself has a "second person" in Richard; a living deposed king, as innumerable histories explained to early modern readers and audiences, remained a threat to the new king that had only one plausible solution. Although Bolingbroke does not order Richard's death, his participation-even obliquely - taints his new rule. Despite being distanced from the actual commission of regicide through a proxy and the absence of a specific order, upon receiving Exton's report, Bolingbroke condemns rather than thanks Exton for his deed: 
They love not poison that do poison need,

Nor do I thee. Though I did wish him dead,

I hate the murderer, love him murdered.

The guilt of conscience take thou for thy labour,

But neither my good word nor princely favour.

With Cain go wander through shades of night,

And never show thy head by day nor light. [Exit Exton.] (R2 5.6.38-44)

While Richard is the poison that infects England, responsibility for Richard's death becomes Bolingbroke's "poison", even as it provides the cure to the problem of Richard's continued existence. ${ }^{2}$ Bolingbroke's kingship begins with the instability inherent to individual charisma, leaving the audience with the uncomfortable sense that Bolingbroke will not be capable of ensuring national stability, because he is a usurper whose future will be fraught with rebellion.

Ultimately, most scholars seem to believe that, despite the rebellions against him, Bolingbroke's personal charisma is triumphant. Barbara Baines argues, specifically, that "The good that Bolingbroke has achieved is a new kind of kingship based on competency, responsibility, and the acknowledgment of political necessity as opposed to a kingship based on an exaggerated theory of divine right" [32]. While Richard's rule was certainly characterized by incompetence-both Gaunt and York speak extensively about his mismanagement of land and wealth and his poor choice in followers-Bolingbroke does not appear to be particularly gifted in any area of rule, except for public relations. Bolingbroke is popular, but as the Henriad progresses, his rule seems defined more by struggle than it does success.

Yet Bolingbroke's reign is also dubbed successful, because it translates, in 1 and 2 Henry IV, into traditional, inheritable charismatic authority for his son, Henry V. As the subject of the final play in the tetralogy, Henry, "the mirror of all Christian kings" (H5 2.0.6), epitomizes both traditional and individual charisma: royal charisma as the fusion of Heil and martial heroism [33]. In granting Henry attributes of both, Charles Barber claims, Shakespeare aligns Henry explicitly with Elizabeth, who similarly "walked a tightrope" between dynastic and personal charismatic rule [34]. However, although Henry has inherited his crown from his father (Bolingbroke), he is preoccupied with the fact that he is only the second of his line. Prior to the battle of Agincourt, he explicitly prays for God to overlook his father's usurpation of Richard's position:

Not today, O Lord,

O not today, think not upon the fault

My father made in compassing the crown. (H5 4.1.289-291)

Henry himself discounts the value of primogeniture as a legitimate means of transferring royal charisma, instead earning his right to claim charismatic authority through "miracles."

Henry's "miracles"- his moral transformation, his martial prowess, his discovery of the treasonous plots against him, his victories at Harfleur and Agincourt and his wooing of Katherine

2 Naomi Conn Lieber, following Girard and Derrida, refers to Richard as a "pharmakos," a poison that is also a cure, a necessary sacrifice whose violent death mitigates further violence [31]. 
of France-all conform to the idealized image of the royal charismatic. In 1 and 2 Henry IV, "Prince Hal" (Henry V) overcomes his personal vices to become a Godly prince, as the bishops of Ely and Canterbury remark at the opening of Henry $V$ :

CANTERBURY The King is full of grace and fair regard.

ELY And a true lover of the holy Church.

CANTERBURY The courses of his youth promised it not.

The breath no sooner left his father's body

But that his wildness, mortified in him,

Seemed to die, too; yea, at that very moment,

Consideration like an angel came

And whipped th'offending Adam out of him,

Leaving his body as a paradise

T'envelop and contain celestial spirits.

Never was such a sudden scholar made,

Never came reformation in a flood

With such a heady currence scouring faults,

Nor never Hydra-headed wilfulness

So soon did lose his seat, and all at once,

As in this king.

ELY We are blessed in the change. (H5 1.1.22-37)

The image Henry presents in this fourth play is one of both piety and heroism, confirmed by the Chorus's description of him as a paragon warrior in the Prologue:

Then should the warlike Harry, like himself,

Assume the port of Mars, and at his heels,

Leashed in like hounds, should famine, sword and fire

Crouch for employment. (H5 Prologue.5-8)

Both the "mirror of all Christian kings" and the "port of Mars," Henry embodies Heil and monarchical heroism, and is capable of leadership in court and on the battlefield.

Just before battle, Henry's men - noble and common alike - are in poor spirits, hungry and facing what they believe to be certain death. Westmoreland remarks to Henry that he wishes "we now had here/But one ten thousand of those men in England / That do no work today!" (H5 4.3.16-18). Henry replies:

No, my fair cousin:

If we are marked to die, we are enough

To do our country loss, and if to live,

The fewer men, the greater share of honour.

God's will, I pray thee wish not one man more. (H5 4.3.19-23)

The valuation of his companions as worthy of their shared honor cements a bond between them and their king, and the remainder of the speech underscores the importance of participation and ratification to the success of Henry's royal charisma: 
We would not die in that man's company

That fears his fellowship to die with us.

This day is called the feast of Crispian.

He that outlives this day and comes safe home

Will stand a-tiptoe when this day is named

And rouse him at the name of Crispian. (H5 4.3.38-43)

Here, Henry not only effaces the class-division between himself and his followers, reinforcing the validity of their approval of his actions and confirming the English participatory tradition of governance, but he also invokes the a mythic narrative of heroism in which his followers will be able to take part, should they choose to accept his vision. Henry continues, mythologizing his vision as the future history of England in which he and his followers will jointly participate:

He that shall see this day and live old age

Will yearly on the vigil feast his neighbours,

And say 'Tomorrow is Saint Crispian.'

Then will he strip and show his scars,

And say 'These wounds I had on Crispin's day.'

Old men forget; yet all shall be forgot

But he'll remember, with advantages,

What feats he did that day. (H5 4.3.44-51)

Henry's vision of triumph over crisis is inspiring to his men, but also to Shakespeare's audience, who must also be prepared to follow their royal charismatic monarch "unto the breach" (H5 3.1.1) of an uncertain future.

But where Henry is most effective is in his elision of the hierarchical difference between himself and his followers:

Crispin Crispian shall ne'er go by

From this day to the ending of the world

But we in it shall be remembered,

We few, we happy few, we band of brothers.

For he today that sheds his blood with me

Shall be my brother; be he ne'er so vile,

This day shall gentle his condition.

And gentlemen in England now abed

Shall think themselves accursed they were not here,

And hold their manhoods cheap whiles any speaks

That fought with us upon Saint Crispin's day. (H5 4.3.57-67)

By promoting participation in his collective vision, Henry is able to use rhetoric to convince his men-who were both doubtful and frightened the night before - to follow him not simply into combat, but to "miraculous" victory. Furthermore, he engages in what Yeon Choi and Renate Mai-Dalton term "self-sacrificial leadership," that is, "leadership which involves denying 
self-interests or personal comfort and safety, limiting personal privileges, or sharing pains and hardships with the followers" [35]. Henry's speech is effective because he both acknowledges the sacrifices of his men while offering them a cohesive vision of their impending victory against impossible odds - a charismatic "miracle" not unlike the Elizabethan victory over the Spanish Armada, to which it obliquely refers.

The so-named "Saint Crispin's Day speech" is remarkable, because of its depiction of Henry's royal charisma, specifically, Terrell L. Tebbets observes, in terms of its "attempts to win consent" from Henry's followers [36]. The speech, as has often been noted, echoes in setting and discursive style Elizabeth's famous "Tilbury Speech," in which, according to a contemporary, Dr. Lionel Sharp, she "rode through all the squadrons of her army as armed Pallas attended by noble footmen, Leicester, Essex, and Norris, then lord marshal, and divers other great lords. Where she made an excellent oration to her army, which the next day after her departure, I was commanded to redeliver all the army together, to keep a public fast" [37]. The text of Elizabeth's speech-as reported by Sharp — is also clearly echoed by Henry's "Saint Crispin's Day" address: "Wherefore I am come among you at this time but for my recreation and pleasure, being resolved in the midst and heat of the battle to live and die amongst you all, to lay down for my God and for my kingdom and for my people mine honor and my blood even in the dust." Henry's speech, clearly patterned after Elizabeth's, desires the audience to see Henry as, Sharon Discorfano claims, an "ideal... charismatic, eloquent, inspiring, and capable of leading others to victory as he stands right alongside them" [38]. In the Saint Crispin's Day speech, Henry fulfills the rhetorical expectations of his followers, both those contained within the framework of the play and those in the playhouse audience, in a charismatic display that resonated with Shakespeare's and continues to resonate with modern audiences [39]. However, despite his ability to produce exemplary moments of idealized royal charisma, Henry's kingship is ultimately problematic.

\section{The Problem with Henry, Elizabeth and Charismatic Succession}

Critics of early modern drama cannot agree on the play's ultimate depiction of Henry or the institution of the monarchy. On one side, Henry Hudson and Henry Edmondson contend that Henry's "many-sidedness" and "inner merit" produce a "portrait of the ideal leader" [40,41]. On the other, Peter Parolin states that "[w]hile on the one hand, Shakespeare's play supports Henry's heroic rhetoric by connecting it with God, on the other hand, the play massively undercuts Henry's godliness and calls his use of godly rhetoric into question" [42]. Similarly, Nina Taunton and Sara Munson Deats find Henry to be fundamentally self-serving, seeking to "appease his insecurity and vanity" and engaging in unjustified "rapacious violence" through his threats against Harfleur and his order to execute the French prisoners of war [43,44]. Malcolm Pittock is even more critical of Henry, suggesting that he is guilty of "moral inauthenticity", because he "accepts no responsibility for his own actions" [45]. For Pittock and others, Henry is Machiavellian, "clever enough to manipulate public opinion, often by an appeal to traditional values, believing that (s)he was the mirror of all Christian kings, while actually engaging in less than scrupulous 'realpolitik'." The added "(s)" is Pittock's conflation of Henry with Elizabeth, a frequent parallel made by critics and one most likely also made by Shakespeare's audience. But, while many scholars see in Henry a criticism of Elizabethan politics, others, myself included, find, instead, an active discussion of the 
state of the English monarchy as an institution, rather than a condemnation of an individual leader, either present or past [46].

The source of vexation concerning Henry is the transparency given to him by Shakespeare, particularly throughout 1 and 2 Henry $I V$, and the night before the battle of Agincourt in Henry $V$. Because the audience witnesses Henry's private, non-charismatic struggles, and because he fails to provide England with security, Henry's success as a royal charismatic ultimately fails to soothe an early modern audience's fears about the death of their own royal charismatic queen. By deliberately exposing the machinery of image creation - a necessary component of royal charisma-Shakespeare draws the audience's attention to the inherent fictiveness and instability of royal charisma, whether Heil or heroism. Henry $V$, in particular, is concerned with the fragility of the king's charismatic persona and deliberately deconstructs it in order to emphasize the danger of governmental reliance on individual, rather than institutionalized, charismatic monarchy.

In 1 Henry $I V$, in which Shakespeare introduces the audience to "Prince Hal," a profligate and often-inebriated wastrel, he also demonstrates the deliberately constructed nature of "Hal"; Henry has every intention of making use of his poor reputation in order to perform the "miracle" of self-reformation that we see in Henry $V$ :

So when this loose behaviour I throw off

And pay the debt I never promised,

By how much better than my word I am,

By so much shall I falsify men's hopes;

And, like bright metal on a sullen ground,

My reformation, glittering o'er my fault,

Shall show more goodly and attract more eyes

Than that which hath no foil to set it off.

I'll so offend to make offence a skill,

Redeeming time when men think least I will. (1H4 1.2.198-207) [47]

Henry's self-presentation here serves multiple purposes: it allows him to develop a complex understanding of the lower classes (his followers) and their motivations; it enables him to "offset" his later goodness; and it represents to the audience the conscious self-construction in which monarchs engaged.

At the conclusion to 2 Henry IV, after the death of Henry's father (Bolingbroke), Henry casts off his common and somewhat immoral company and lays claim to the aspects of royal charisma we see more fully developed in Henry $V$. Following his coronation, Henry is approached by his erstwhile companions, Falstaff, Shallow, Pistol and Bardolph (the latter two of whom reappear in Henry V), and addressed by Falstaff as "My King! My Jove!” (2H4 5.5.46). Henry's response fulfills the "debt" of self-transformation he "promised":

Presume not that I am the thing I was;

For God doth know, so shall the world perceive,

That I have turn'd away my former self;

So will I those that kept me company. 
When thou dost hear I am as I have been,

Approach me, and thou shalt be as thou wast,

The tutor and the feeder of my riots.

Till then I banish thee, on pain of death,

As I have done the rest of my misleaders. (2H4 5.5.56-64) [48]

Because by Henry $V$, the audience has seen Henry in two previous plays, they are aware that his royal charisma is a projected persona. This cognizance of the externality of royal charisma significantly undermines any claim of inherent Heil, and Henry makes no such claims for himself or for monarchs in general. In fact, if anything, Henry claims the opposite.

The night before Agincourt, Henry disguises himself as a commoner and moves among his men in order to take the measure of their fear and-if Deats's argument is to be believed - to assuage his own. Following this confrontation, during which Henry learns that his men hold him accountable for their lives and souls, Henry discloses his own fallibility:

I think the King is but a man, as I am: the violet smells to him as it doth to me; the element shows to him as it doth to me; all his senses have but human conditions; his ceremonies laid by, in his nakedness he appears but a man; and though his affections are higher mounted than ours, yet when they stoop they stoop with the like wing. (H5 4.1.102-108)

Here, Henry is disguised as a common soldier, and he therefore employs "common" rather than elevated speech in his explanation to both soldiers and playhouse audience that he - as king-is no different than they, nor is he-as player-distinct in makeup from the monarch on the throne. In this admission of humanity, Shakespeare, through Henry, directly undercuts Continental claims of traditional charismatic authority. While Henry may act in accordance with both the heroic and spiritual aspects of royal charisma, he does not possess inherent Heil. Instead, Henry has deliberately constructed a royal charismatic persona with the appearance of both Heil and heroism.

What is most interesting about the constructed nature of Henry's royal charisma is that the play did not condemn it. Rather, Henry's charismatic performance is praiseworthy, since it enables him to lead his men to victory at Agincourt and to achieve conquest-legitimizing his charismatic persona by making him a founding king. The play's concern is not that Henry performs his way into royal charisma, but that such charisma is, as Weber notes, inherently unstable, as Richard Hardin explains: "an impulse toward sacralizing the monarch goes awry, as it always must, since in any human sacredness is an unstable commodity" [49]. In dismantling the veracity of claims of divine right and inherent sovereign Heil, the play exposes the problem of instability that provided the impetus for most of the drama of the period, focusing on the consequence of charismatic instability and the consequent failure of succession.

Although the Tudor dynasty had long relied upon claims of divine right and foundational kingship as a means of legitimization, Elizabeth herself had been careful to situate her own claims of royal charisma in her love for her people rather than in her God-given right to rule: "For I do esteem it more than any treasure or riches; for that we know how to prize, but love and thanks I count unvaluable. And, though God hath raised me high, yet this I count the glory of my crown, that I have reigned with your loves. This makes me that I do not so much rejoice that God hath made me to be a Queen, as to be a Queen over so thankful a people." Taken from her Golden 
Speech, given November 30, 1601, these lines echo claims made throughout her reign - that the ratification of the populace was ultimately of greater importance to her continued rule than divine endowment. Whether these claims indicated her true beliefs or whether they were a performance for the public and Parliament is - as we saw with Henry V-ultimately unimportant; what is important is that the persona Elizabeth constructed was one of a limited monarch willing to accept her people's judgment.

The concluding problem of Henry $V$ ultimately has very little to do with Henry's constructed - successful — charismatic persona. In fact, the play's unsatisfying ending is the product of its epilogue, in which the audience is reminded of the events following Henry's victories in France. The Henriad is Shakespeare's second tetralogy; the first tetralogy (written 1590-1593, according to most scholarship) follows Henry's son through his own failures in France, cuckolding, deposition and murder, against the backdrop of the Wars of the Roses. Because the first tetralogy, although chronologically second, was written and staged first, the audience of the Henriad knew the conclusion to the story. E.M.W. Tillyard has famously proposed that the entire sequence was written in praise of the Tudor dynasty, what has come to be termed the Tudor Myth, an idea that has been widely praised and criticized since [50-53].

Rather than laud or condemn the Tudor dynasty, the narrative contained within the tetralogies deliberately points to the breakdown of the illusion of national stability fostered under the rule of a royal charismatic. In Henry $V$, Henry's "miracles" and public successes create a sense of national permanence and perpetuity, necessitating the reminder at its conclusion of immanent civil and international strife:

CHORUS Small time, but in that small most greatly lived

This star of England. Fortune made his sword

By which the world's best garden he achieved,

And of it left his son imperial lord.

Henry the Sixth, in infant bands crowned King

Of France and England, did this king succeed,

Whose state so many had the managing

That they lost France and made his England bleed,

Which oft our stage hath shown; and for their sake

In your fair minds let this acceptance take. (H5 Epilogue.5-14)

The reference to "Small time," the fact that Henry VI was crowned as an infant, and the events contained within the already extant first tetralogy all remind the audience that regardless of Henry's successes, they are ultimately transient, and he leaves, in Parolin's terms, "a legacy of loss." Henry's royal charisma is insufficient to stabilize England and France as a unified nation, just as Elizabeth's royal charisma will not be able to provide perpetual stability for Shakespeare's England.

Henry $V$ 's epilogue does not provide an adequate solution for the problem of charismatic instability at first glance, yet the history plays in general do suggest a possible answer in the form of their critique of the institution of monarchy. Henry $\mathrm{V}$ himself, in fact, provides part of this 
answer in his own refusal of Heil. In short, the answer to the question, "[b]ut when conquest yields to stabilization, youth to age, fabulous exploits to everyday reality, how can charisma be 'routinized'?" lies in the process of institutionalization. In Elizabethan England, this process involved a turn toward medieval tradition, a shift back toward to English participatory limited monarchy and a rejection of Continental claims of absolutism and divine right.

This philosophical return to a medieval understanding of sovereignty augmented by a modern progression toward bureaucratization indicated the shifting attitude throughout the nation and the government as a whole. Elizabeth was queen over an assertive Parliament and Privy Council, both bodies who drew their existence and authority from English medieval tradition. By the last decade of the sixteenth century, both Parliament and the Council had repeatedly attempted to assert their authority over Elizabeth, who continued to resist their insistence that she marry or name an heir. In 1584, William Cecil attempted to "establish a Great Council to rule England in the event of an assassination and the inevitable interregnum that would follow. The Great Council would exercise all the royal powers and together with a recalled Parliament would choose the next monarch." Elizabeth refused Cecil's proposal, stating that it violated her rights as a monarch and, David Starkey notes, would have "permitted subjects to judge a sovereign and elect a new one." Nevertheless, Cecil's proposal and the 1571 Act of Parliament that made it treason to question Parliamentary right to alter the succession both indicate the ideological shift taking place within the structure of the English monarchical institution away from centralized monarchy [54]. While the traditional means of succession in England - as elsewhere - remained tied to blood, these incidents focus on the legal alteration of succession by a body other than the centralized figure of charismatic authority. In short, the English monarchy was becoming bureaucratized.

The process of creating an institutionalized bureaucracy out of the English monarchy was at its core an attempt to create stability and continuity between monarchs - to streamline the process of succession in such a way that royal charisma became routinized. The routinization of charisma, according to Weber, results from the "desire to transform charisma and charismatic blessing from a unique, transitory gift of grace of extraordinary times and persons into a permanent possession of everyday life." This process of transformation, however, necessarily "changes the nature of the charismatic structure." So, too, did the process of bureaucratization alter the nature of royal charisma in early modern England by divorcing royal charisma from the individual ruler and attaching it, instead, to the office of monarch itself - an office required to submit to the limitations stipulated by Parliament, Council and law.

The office of monarch was attached, in traditional understandings of charisma, to the individual king or queen sitting on the throne. The English propensity for limiting monarchy, however, meant that a legal fiction was needed in order to maintain a separation between the person of the monarch and the office that person held. This became particularly important during the Tudor dynasty, when three of its five monarchs were in some way believed inadequate for the position: one minor (Edward VI) and two women (Mary I and Elizabeth I). The legislative reaction to this problem was to make distinct the monarch's body natural (personal, physical body) from his or her body politic (the metaphysical construct of the monarch-in-state), as is described in Edmund Plowden's Commentaries or Reports in a response to a land-disposition case in 1562: "The King has two Bodies, viz., a Body natural, and a Body Politic. His Body natural ... is a Body mortal, subject to 
all infirmities that come by Nature or Accident... But his Body politic is a Body that cannot be seen or handled, consisting of Policy and Government, and constituted for the Direction of the People... and this Body is utterly void of... natural Defects and Imbecilities, which the Body natural is subject to" [55]. This division-explored at some length by Kantorowicz-enabled a monarch limited by age, physical ability or illness to nevertheless execute the full extent of sovereign powers. However, this division also enabled the opposite; in addition to authorizing the monarch to take actions otherwise inappropriate to his age or her gender, the division between office and person created a gap into which Parliament and the Privy Council were able to step in order to assert authority over the process of succession.

The impulse to divide the individual king or queen from the office of monarch produced a corresponding increase in the power-distribution to the offices that surrounded the throne, in particular, among members of the Privy Council-like Cecil-and Parliament. The location of power in these bodies was not new to the Elizabethan period, but the degree to which Councilors and members of Parliament felt authorized to execute power over both the monarch and the succession was much more recent. Thomas Anderson locates the beginnings of this development in the fifteenth century, citing the relocation of "official state business away from the king's household or court and into what some historians consider an independent administrative service" [56]. Anderson echoes A.L. Brown's thesis that the end of the fifteenth century saw the advent of professional government servants, men whose role was life-long (or, at least, for the duration of a given monarch's reign) and concerned primarily with administration [57].

The separation of the business of running of the nation from the person of the monarch, Michael Braddick maintains, is a consequence of the ideological conception of England as a "state," rather than a "kingdom" affiliated specifically with the crown [58]. John Guy explains that this understanding of "state," rather than "kingdom," arose during Elizabeth's reign and is symptomatic of the larger changing conception of monarchy as being rooted in the "state" rather than the individual sovereign, what Weber refers to as a "legal authority," rather than a "traditional" or "charismatic" one [59]. The existence of professional governmental administrators, the increasing power of Parliament and the Privy Council and the removal of the person of the monarch from the formal execution of sovereign authority all demonstrate the bureaucratization - the routinization - of royal charisma at the end of the sixteenth century.

Although, as Braddick notes, Elizabethan England was not yet a "rational bureaucracy" in Weber's explicit terms, this period of time did see the establishment of the foundations of what would become "a kind of bureaucracy, a 'central machine', and around this core of London government there developed a range of full-time functionaries," which included the monarch, as the embodiment of royal charisma, and also the proto-bureaucratic bodies of Parliament and the Privy Council, whose authority increased, as individual bureaucrats like William and Robert Cecil asserted their power over Elizabeth and her successor. This machinery of Elizabethan bureaucracy would have been apparent to Shakespeare as a liveried servant of the Lord Chamberlain, and, as such, the playwright would have been capable of observing and commenting on the shift in powerdynamics at court. 


\section{Conclusions}

What is perhaps most interesting about the shift toward bureaucratization in Elizabethan England is that, while its immediate concern — as Shakespeare's drama reveals — was with the impending problem of succession, it ultimately meant a reduction in sovereign power, as the individual monarch began to appear increasingly as a figurehead rather than an arbiter of law and justice. The loyalty demonstrated by subjects and even administrators became relocated from the monarch to the crown itself, as, Kantorowicz explains, we see occur in Richard II: "kings were not rarely charged - we may think of Edward II or Richard II - with having 'blemished and prejudiced the Crown and the royal Dignity and the heirs Kings of England." The problem with Richard II was that he violated the terms of his coronation and, in doing so, exacerbated the division between his individual person and his role as monarch, permitting Bolingbroke's usurpation. However, as is evident in the remaining three plays, individual royal charisma ultimately proves to be as unstable as traditional divine right charisma.

Although Bolingbroke's demonstration of both Heil and heroism gained him the crown at the conclusion of Richard II, the elimination of inherent sanctity from the throne created the repeated opportunity for rebellion against his regime. Furthermore, even though Henry V was able to more fully claim the throne as Bolingbroke's heir, war hero and pious Christian, even this idealized image of royal charisma was insufficient to secure England's future stability. The primary concern with which Shakespeare leaves his audience at the end of the Henriad is that although royal charisma produces an idealized monarchy, that ideal circumstance is temporary, threatened by the inherent instability of the very charisma that makes it appear ideal. What we see in the epilogue of Henry $V$ is the legitimate concern that the interregnum that would happen upon Elizabeth's death had the potential to threaten the overall security of England itself.

What ultimately transpired, of course, was that England saw no such interregnum. Instead, riders were immediately dispatched to Scotland to inform James VI that he had been proclaimed James I of England on Elizabeth's deathbed, and England experienced a smooth transition from the Tudor to the Stuart dynasty. ${ }^{3}$ James himself was a proponent of the very sort of divine right charisma-Heil alone - which England had traditionally rejected, but the stability offered by the smooth succession of a king who already had produced an heir (and the proverbial "spare") was more enticing than civil or international conflict. As James MacGregor Burns notes, historically, stability and absolutism were preferable to participatory governance and instability: "So most peoples, during most of history, learned one paramount lesson-ideally it would be best to have regimes both properly chosen and stable, but if you have to choose between autocracy and instability, take autocracy. Though a despot may oppress and murder citizens who threaten his power, civil war resulting from succession struggles can ensnare whole societies and cause the deaths of thousands" [60]. While this bore out in the process of James's accession, it would ultimately prove to be too harsh of a transition for a nation long accustomed to a limited participatory government that was already undergoing the process of bureaucratization. James repeatedly found himself in conflict with both Parliament and the Privy Council, and his assertions

3 While the official account is that he was designated by Elizabeth herself, apocryphal stories suggest that the decision may have been made by Robert Cecil or the Privy Council. 
of divine authorization were met on both the political and public stages with condemnation and derision, despite official and clerical attempts to insist otherwise.

The role played by the public theaters in the transformation is often overlooked in examinations of the changes in governmental structure and public policy. Plays, like Shakespeare's Richard II, which foreground deposition and regicide, reproduced the attitudinal shift away from absolutism and toward bureaucratization, but the frequency with which such events (fictional and historical) appeared on the public and courtly stages in the half-century leading up to the closure of the theaters in 1642 suggests their power was not simply reflective. The concerns of anti-theatricalists and official censors tells us that the theaters held transformative power over their audiences and led to the public acceptance - and, indeed, the expectation — of institutionalized rather than inherent royal charisma.

The ultimate consequence of frequent theatrical depiction of the routinization of royal charisma in England meant that the nation was incapable of accepting assertions of personal or divine right charismatic authority, since the establishment of participatory bureaucracy was an institutional and ideological step that could not be revoked. In short, the long-standing tradition of participatory limited monarchy set the stage - both literally and figuratively_for the creation of a monarchical bureaucracy that insisted upon its right to regulate and designate the succession of routinized royal charismatic authority. The attempt of the Stuart dynasty to insist upon its traditional charismatic authority resulted, in 1649, in the conviction and execution of Charles I in Parliament's ultimate assertion of its bureaucratic power over not only succession, but of the persistence of the crown itself.

\section{Acknowledgments}

I would like to thank and acknowledge my colleague, Peter Iver Kaufman, for his encouragement in submitting this manuscript and to Tammy Tripp for her continued assistance with formatting and bibliographic references.

\section{References and Notes}

1. John Gardner. On Leadership. New York: The Free Press, 1990, p. 34.

2. Bernard M. Bass. "On the Taming of Charisma: A Reply to Janice Beyer." Leadership Quarterly 10 (1999): 541-53.

3. Max Weber. Economy and Society: An Outline of Interpretive Sociology, 2nd ed. Edited by Guenther Roth, and Claus Wittich. Berkeley: University of California Press, 1978, vol. 2.

4. Henry Allen Myers. Medieval Kingship. Chicago: Nelson-Hall, 1982.

5. J.P. Sommerville. Royalists and Patriots: Politics and Ideology in England 1603-1640, 2nd ed. London: Longman, 1999.

6. Bettina Sejbjerg Sommer. "The Norse Concept of Luck." Scandinavian Studies 79 (2007): 275-94.

7. James I. "The Trew Law of Free Monarchies: Or the Reciprock and Mvtvall Dvetie Betwixt a Free King, and his Naturall Subjects." In The Political Works of James I. Edited by Charles Howard McIlwain. Cambridge: Harvard University Press, 1918, pp. 24-25. 
8. Ernst Kantorowicz. The King's Two Bodies: A Study in Mediaeval Political Theology. Princeton: Princeton University Press, 1957.

9. Stephen Greenblatt. "Introduction: Fifty years of the King's Two Bodies." Representations 106 (2009): 63-66.

10. Richard Halpern. "The King's Two Buckets: Kantorowicz, Richard II, and Fiscal Trauerspiel." Representations 106 (2009): 67-76.

11. Lorna Hutson. "Imagining Justice: Kantorowicz and Shakespeare." Representations 106 (2009): 118-42.

12. Bernhard Jussen. "The King's Two Bodies Today." Representations 106 (2009): 102-17.

13. Victoria Kahn. "Political Theology and Fiction in The King's Two Bodies." Representations 106 (2009): 77-101.

14. David NorbrookD. "The Emperor's New Body: Richard II, Ernst Kantorowicz, and the Politics of Shakespeare Criticism." Textual Practice 10 (1996): 329-57.

15. Max Weber. Economy and Society: An Outline of Interpretive Sociology, 2nd ed. Edited by Guenther Roth, and Claus Wittich. Berkeley: University of California Press, 1978, vol. 1.

16. John Wiedhofft Gough. The Social Contract: A Critical Study of Its Development, 2nd ed. Oxford: Clarendon Press, 1957, p. 3.

17. David Starkey. Crown and Country: The Kings \& Queens of England: A History. London: HarperPress, 2006.

18. Franklin Le Van Baumer. The Early Tudor Theory of Kingship. New York: Russell \& Russell, 1966, p. 124.

19. C. Warren Hollister. The Making of England: 55 B.C. to 1399, 7th ed. D.C. Lexington: Heath and Company, 1996.

20. Clayton Roberts, and David Roberts. A History of England: Prehistory to 1714, 2nd ed. Englewood Cliffs: Prentice-Hall, Inc., 1985, vol. 1.

21. Lacey Baldwin Smith. This Realm of England: 1399-1688, 7th ed. Lexington: D.C. Heath and Company, 1996, vol. 2.

22. Garry Wills. Certain Trumpets: The Nature of Leadership. New York: Simon \& Schuster, 1994.

23. Third Act of Succession, 25 Hen. VIII Cap. 22. Kew Gardens: The National Archives, 1534.

24. Roy Strong. Gloriana: The Portraits of Queen Elizabeth I. New York: Thames and Hudson, 1987, pp. 131-32.

25. Jay A. Conger. 'Charismatic and Transformational Leadership in Organizations: An Insider's Perspective on These Developing Streams of Research." Leadership Quarterly 10 (1999): 172.

26. Elizabeth I. Elizabeth I Collected Works. Edited by Leah S. Marcus, Janel Mueller, Mary Beth Rose. Chicago: The University of Chicago Press, 2000.

27. William Cecil. "Cecil's Report to the Full House of Commons November 6, 1566, on Elizabeth's Speech of November 5." In Elizabeth I Collected Works. Edited by Leah S. Marcus, Janel Mueller, Mary Beth Rose. Chicago: The University of Chicago Press, 2000, p. 99.

28. William Shakespeare. King Richard II, 3rd series. Edited by Charles R. Forker. London: Arden Shakespeare, Thomson Learning, 2002. 
29. Cajsa C. Baldini. "A Courtier or a Prince: Shakespeare's Richard II as a Dramatization of Conflicting Paradigms of Craftsmanship.” Forum Italicum 37 (2003): 66.

30. Aaron Landau. "I Live With Bread Like You': Forms of Inclusion in Richard II." Early Modern Literary Studies 11 (2005): 3.6.

31. Naomi Conn Lieber. "The Mockery King of Snow: Richard II and the Sacrifice of Ritual." In True Rites and Maimed Rites. Edited by Linda Woodbridge, Edward Berry. Urbana: University of Illinois Press, 1992, pp. 220-39.

32. Barbara J. Baines. "Kingship of the Silent King: A Study of Shakespeare's Bolingbroke." English Studies: A Journal of English Language and Literature 61 (1980): 24-36.

33. William Shakespeare. King Henry V, 3rd series. Edited by T.W. Craik. London: Arden Shakespeare Routledge, 1995.

34. Charles Barber. "Prince Hal, Henry V, and the Tudor Monarchy." In The Morality of Art: Essays Presented to G. Wilson Knight by His Colleagues and Friends. Edited by D.W. Jefferson. London: Routledge, 1969, p. 68.

35. Yeon Choi, and Renate R. Mai-Dalton. "On the Leadership Function of Self-Sacrifice." The Leadership Quarterly 9 (1998): 475-501.

36. Terrell L. Tebbetts. "Shakespeare's Henry V: Politics and the Family." South Central Review 7 (1990): 16.

37. Lionel Sharp. "Letter from Dr. Lionel Sharp." In Elizabeth I Collected Works, edited by Leah S. Marcus, Janel Mueller, Mary Beth Rose. Chicago: The University of Chicago Press, 2000, p. 325.

38. Sharon Discorfano. "The Creation of a Leader in Shakespeare's 'Henry V'." Leadership in Action 23 (2003): 11.

39. Raed Awamleh, and William L. Gardner. "Perceptions of Leader Charisma and Effectiveness: The Effects of Vision Content, Delivery, and Organizational Performance." Leadership Quarterly 10 (1999): 345-73.

40. Henry N. Hudson. "Introduction." In King Henry the Fifth. Edited by Henry N. Hudson, William Shakespeare. Boston: Ginn \& Company, 1889, pp. 16-17.

41. Henry T. Edmondson III. "Shakespeare's Henry V and the Act of Ethical Reflection." In The Moral of the Story: Literature and Public Ethics. Edited by Henry T. Edmondson III. Lanham: Lexington Books, 2000, p. 61.

42. Peter Parolin. "Figuring the King in Henry V: Political Rhetoric and the Limits of Performance." Journal of the Wooden O Symposium 9 (2009): 43-60.

43. Nina Taunton. 1590s Drama and Militarism: Portrayals of War in Marlowe, Chapman, and Shakespeare's Henry V. Aldershot: Ashgate, 2001, p. 177.

44. Sara Munson Deats. "Henry V at War: Christian King or Model Machiavel." In War and Words: Horror and Heroism in the Literature of Warfare. Edited by Sara Munson Deats, Lagretta Tallent Lenker, Merry G. Perry. Langham: Lexington Books, 2004, pp. 83-101.

45. Malcolm Pittock. "The Problem of Henry V." Neophilogus 93 (2009): 175-190.

46. Christopher Pye. The Regal Phantasm: Shakespeare and the Politics of Spectacle. London: Routledge, 1990. 
47. William Shakespeare. King Henry IV Part 1, 3rd series. Edited by David Scott Kastan. London: Arden Shakespeare, Thomson Learning, 2006.

48. William Shakespeare. King Henry IV Part 2, 2nd series. Edited by A.R. Humphreys. London: Arden Shakespeare, Methuen, 1981.

49. Richard F. Hardin. Civil Idolatry: Desacralizing and Monarchy in Spenser, Shakespeare, and Milton. Newark: University of Delaware Press, 1992, p. 38.

50. E.M.W. Tillyard. Shakespeare's History Plays, New York: The Macmillan Company, 1946.

51. Jonathan Dollimore, and Alan Sinfield. "History and Ideology: The Instance of Henry V." In Alternative Shakespeares. Reprint. Edited by John Drakakis. Routledge: London, 2001; p. 214.

52. William Haller. The Elect Nation: The Meaning and Relevance of Foxe's Book of Martyrs. New York: Harper \& Row, Publishers, 1963, p. 167.

53. Robin Headlam Wells. "The Fortunes of Tillyard: Twentieth-Century Critical Debate on Shakespeare's History Plays." English Studies: A Journal of English Language and Literature 5 (1985): 391-403.

54. 13 Eliz. Cap. 1. Kew Gardens: The National Archives, 1571.

55. Edmund Plowden. Commentaries or Reports. Dublin: H. Watts, 1792, p. 212a.

56. Thomas Anderson. "Legitimation, Name, and All Is Gone': Bastardy and Bureaucracy in Shakespeare's King John." Journal for Early Modern Cultural Studies 4 (2004): 35-61.

57. A.L. Brown. The Governance of Late Medieval England 1272-1461. Stanford: Stanford University Press, 1989, p. 60.

58. Michael J. Braddick. State Formation in Early Modern England C. 1550-1700. Cambridge: Cambridge University Press, 2000.

59. John Guy. Tudor England. Oxford: Oxford University Press, 1988, p. 352.

60. James MacGregor Burns. Transforming Leadership: A New Pursuit of Happiness. New York: Grove Press, 2003, p. 37. 
Reprinted from Religions. Cite as: Goethals, G.R. "Charismatic Reactions to Individuals and Ideas: Looks, Language and Lincoln.” Religions 4 (2013): 209-215.

\title{
Charismatic Reactions to Individuals and Ideas: Looks, Language and Lincoln
}

\author{
George R. Goethals
}

\begin{abstract}
This paper explores the application of Freud's theories of leadership and group psychology to the case of Abraham Lincoln. It argues that followers' needs for charismatic leaders propel them to construct heroic and charismatic cognitive representations of leaders who give the impression of power and who represent the ideal qualities of the group. Both leaders and their ideas can create an emotional connection with followers. During his lifetime, Americans developed charismatic and heroic interpretations of Abraham Lincoln's appearance. They also responded positively to Lincoln's use of biblical rhythms and phrases in his speeches and writings.
\end{abstract}

In the 2012 film Hyde Park on Hudson, Laura Linney portrays Franklin D. Roosevelt's (FDR) distant cousin and confidant Daisy Suckley [1]. The film, based in part on Suckley's recently discovered diaries, has her suggesting that the press, the public and FDR himself all worked, for their own reasons, to maintain the heroic, charismatic image of Roosevelt that seemed so important to the nation's psyche in mid-1939. For example, photographers generally cooperated in not taking pictures of Roosevelt being transferred bodily from his wheelchair to his car, or from his car into buildings. People knew he had polio, but all parties preferred pictures of FDR that showed him looking confident and powerful. Human beings have a need for heroes and strong, charismatic leadership. They construct cognitive representations of individual leaders that allow them to develop and maintain heroic images [2]. Like FDR, leaders often are active participants in what we might call leadership theatre, designed to give follower audiences what they wish for. John Keegan (1986) puts it well. "The theatrical impulse will be strong in the successful politician... and will be both expected and reinforced by the audiences to which they perform.... The leader of men... can show himself to his followers only through a mask, a mask that he must make for himself, but a mask made in such form as will mark him to men of his time and place as they leader they want and need" ([3], p. 11).

This paper considers the construction and also the experience of charisma in the specific case of Abraham Lincoln. We first develop three points. One, people have a need for charismatic leaders, and do considerable cognitive work to manufacture charismatic perceptions of their leaders. Second, charisma is something that is felt as well as perceived. There is an emotional connection between leaders perceived as charismatic and the followers who so perceive them. Third, part of the reaction to charismatic leaders is attachment to their ideas and the language which expresses them, as well as to them as persons. After considering these points, we address the ways in which 
Abraham Lincoln's persona, his ideas, commitments and language produced charismatic reactions. We emphasize the power of biblical language in Lincoln's speeches and writings.

Many of the ideas outlined above were discussed in Sigmund Freud's 1921 essay on "Group Psychology and the Analysis of the Ego," published shortly before Max Weber introduced the term "charisma" into the social science vocabulary [4,5]. Freud emphasized the ways ideas and the persons who hold them combine to give leaders "prestige" and went further to suggest that perhaps ideas themselves can lead and have prestige. Freud's prestige is, of course, in many ways Weber's charisma. While it does not involve the attribution of religious aura to a leader, it is essentially the same concept.

Following the writings of Gustave LeBon, Freud proposed that people thirst for strong leadership but that for an individual to be perceived as such a leader, he (Freud assumed that leaders were male) must have the qualities followers need and expect [6]. The group's "thirst for obedience" carries "it half-way to meet the leader, yet he too must fit in with it in his personal qualities." Anticipating Hogg's notion of the centrality of leader prototypicality, Freud wrote that the leader must "possess the typical qualities of the individuals concerned in a particularly clearly marked and pure form." He must also "give an impression of greater force and of more freedom of libido" ([7], pp. 184-200). Further, in order to compel the attention and obedience of potential followers, the leader must "himself be held in fascination by a strong faith (in an idea) in order to awaken the group's faith; he must possess a strong and imposing will." Freud summarizes LeBon's thinking that "leaders make themselves felt by means of the ideas in which they themselves are fanatical believers." They acquire "a mysterious and irresistible power" which acts as "sort of domination exercised over us." This domination can be exerted "by an individual, a work or an idea" ([4], pp. 81, 129).

Two points are relevant to our eventual consideration of Lincoln. First, the force of the person and the force of her or his ideas combine in some organic way to generate power. Second, the leader's force is experienced deeply, as some kind of "magnetic magic." The experience includes a strong attachment to the leader. Using the language of charismatic leadership, there are two relevant elements [8]. First, the leader is seen to have charisma and second, his charisma is experienced emotionally by followers. Thus, we can speak of charismatic reactions or experiences as well as the charismatic individual. It might be useful to think of charisma as something that happens, something that resides in the followers perhaps more than the leaders.

Freud argues further that leaders have their charismatic effects through illusions, and those illusions operate through "the truly magical power of words." The leader "who wishes to produce an effect upon" followers "needs no logical adjustment in his arguments; he must paint in the most forcible colors, he must exaggerate, and he must repeat the same thing again and again" ([4], pp. 78, 80).

How can we use these ideas to consider whether Abraham Lincoln had charisma in the sense that he himself or his work and words had a "magnetic magic" and "prestige" that both dominated then and dominate now? First, what about Lincoln as an individual, in his own time? Lincoln was as canny a politician as FDR, and wanted, at least, to be seen. Hopefully, reaction to the view would be positive. In his trilogy of Civil War narrative histories, Shelby Foote argues that Lincoln made himself unusually available to the public [9]. As more and more people saw him, or heard 
from others who had, they liked what they saw or heard. Foote explains "...he received all comers, and for the most part received them with a sympathy which, by their own admission, equaled or exceeded their deserving. He shook their hands at frequent public receptions in the White House....; he attended the theater, a form of relaxation which kept him still within their view; he drove or rode, almost daily, through the spokelike streets of the hive-dense city, returning the looks and salutes of men and women and children along the way. Thousands touched him, heard him, saw him at close range, and scarcely one in all those thousands ever forgot the sight of that tall figure, made still taller by the stovepipe hat, and the homely drape of the shawl across the shoulders. Never forgotten, because it was unforgettable, the impression remained, incredible and enduring, imperishable in its singularity - and finally, dear" ([9], p. 802). Similarly, in Richmond, on April 4, 1865, a formerly enslaved African American woman declared "I know that I am free. I have seen father Abraham and felt him” ([10], p. 261). In short, Lincoln's odd appearance and gracious manner became enduringly compelling. That was as much as Lincoln could wish for.

Many people got a closer look through his widely distributed (often by Lincoln) photograph. His face became "the most familiar face in American history." Maybe this was not advantageous. "The Paris correspondent of the New York Times" said he looked like a condemned murderer of servant girls, and that "such a face is enough to ruin the best of causes." However, people's needs for a charismatic hero led many to convince themselves that his face revealed inspiring heroic qualities. Foote writes "you saw it not so much for what it was, as for what it held. Suffering was in it; so were understanding, kindliness, and determination." A young soldier wrote after a Lincoln visit to the front: "None of us to our dying today can forget that countenance....Concentrated in that one great, strong yet tender face, the agony of the life and death struggle of the hour was revealed as we had never seen it before. With a new understanding, we knew why we were soldiers" ([9], pp. 802-03). Thus Lincoln's appearance, at a distance and close up, had an inspiring effect, it made charisma happen.

Lincoln worked hardest to make an emotional connection with his words, spoken and written. Then and more now, his impact comes through those words. They may have more impact today when read by a Sam Waterston or enacted by a Daniel Day-Lewis. Or, people reading them may imagine Lincoln writing or speaking them, thereby adding to their emotional and intellectual impact. Still, it is the words themselves that most move people. What is it about them that gives them such power? One element is Lincoln's use of religious imagery or biblical allusion. Sometimes the use of biblical language is quite direct; sometimes it simply nods to religious themes or content. Biblical language allowed Lincoln to use rhythms and phrases that would have been familiar to large and diverse audiences. The Second Great Awakening would have made such language highly resonant as people pondered Lincoln's meanings ([11], pp. 56-57).

In his famous house divided speech delivered in Springfield, Illinois upon accepting the Republican Party nomination for the U.S. Senate in 1858, Lincoln memorably argued "A house divided against itself cannot stand. I believe this government cannot endure, permanently, half slave and half free" ([12], p. 426). The house metaphor might have had impact by itself, but surely its biblical origins gave it additional power. Lincoln was speaking to an audience which would have varied widely in their education. Of course he himself had very little formal instruction. He attended "blab schools," he said, "by littles," not having much more than one full year in total of 
schooling. But Lincoln had read all and absorbed much of the Bible. His audiences would also likely be familiar with its ideas and cadences, whether they were literate or not. The house divided metaphor derived from language attributed to Jesus in Matthew 3:25: "And if a house be divided against itself, that house cannot stand." Similarly, in a speech to the U.S. Senate during the controversy leading to the Compromise of 1850, Sam Houston from Texas quoted Mark 3:24, "A nation divided against itself cannot stand." By using language from a familiar text with soothing rhythms and inspirational imagery, Lincoln was more likely to move his listeners.

Lincoln's presidential speeches and writings frequently mention or appeal to God. In doing so, he often implied that God was on his (the Union) side. At the end of his December 1862 message to Congress, a speech some of whose last words are set to music in Aaron Copland's Lincoln Portrait, the President concludes his appeal for Congressional support for emancipation using balanced phrasing, alliteration and appeals to honor and eternity. And ultimately he asserts divine support for this position. "In giving freedom to the slave, we assure freedom to the free-honorable like in what we give, and what we preserve. We shall nobly save, or meanly lose, the last, best hope of earth. Others means may succeed; this could not fail. The way is plain, peaceful, generous, just - a way which, if followed, the world will forever applaud, and God must forever bless" ([13], p. 415).

Another example comes from the final Emancipation Proclamation, signed on January 1, 1863. Lincoln concludes a dry, legalistic document full of "Whereas," "Now, therefore I..." and "by virtue of the power, and for the purpose aforesaid..." with appeals to important values and divine approval. The document is often criticized for its legalistic, stilted wording, and also for aspects of its substance. However, given the assertion of Constitutional prerogative in the Proclamation, that tone is appropriate. Still, Lincoln was happy to add toward the conclusion "And upon this act, sincerely believed to be an act of justice, warranted by the Constitution, upon military necessity, I invoke the considerate judgment of mankind, and the gracious favor of Almighty God" ([14], p. 425).

Sometimes Lincoln's use of biblical imagery and appeals to the divine are slightly more subtle. In his first inaugural address, a lengthy discourse on the unconstitutionality and impracticality of secession, Lincoln suggests that passions that "may have strained" and threaten to "break our bonds of affection" may be eased when "the mystic chords of memory" are touched "by the better angels of our nature" ([15], p. 224). In his famous Gettysburg Address, delivered in November, 1863, Lincoln's uses religious terminology without a direct appeal for God's assistance. The speech touches on themes of birth and death, nation and people, and dedication and honor. It famously begins poetically: "Four score..." We could interrupt there. The two words in this short phrase rhyme, and use of a word, "score," more familiar from the Bible than anywhere else. The sentence continues "and seven years ago our fathers brought forth on this continent, a new nation, conceived in Liberty, and dedicated to the proposition that all men are created equal." In the next sentence Lincoln repeats the words "nation," "conceived" and "dedicated": "Testing whether that nation, or any nation so conceived and so dedicated, can long endure." The word "dedicated" appears one more time and the word "dedicate" twice. The noun "devotion" occurs twice. Lincoln also uses the words "consecrate," "hallow," and "consecrated": "But, in a larger sense, we cannot dedicate-we cannot consecrate-we cannot hallow - this ground. The brave men, living and dead, who 
struggled here, have consecrated it far above our poor power to add or subtract." (Then in a self-deprecating aside, opposing word and deed, with an embedded double alliteration, the President says "The world will little note, nor long remember what we say here...") [16]. Toward the end, in a more explicit religious phrasing, Lincoln states that included in the "unfinished work" and "great task remaining before us" is to ensure "that this nation, under God, shall have a new birth of freedom" ([17], p. 536). The speech, then, is laced with religious, quasi-religious and biblical wording. Such wording would strike a familiar chord, create a positive association, and add to the charismatic appeal of the speech. It would help produce a charismatic emotional reaction, or as we have framed it earlier, make charisma happen.

The text of two short speeches adorn the Lincoln Memorial in Washington, DC. The Gettysburg Address is one. The other is the Second Inaugural Address, often regarded as Lincoln's greatest speech. The first part of the latter refers to the "reasonably satisfactory and encouraging" "progress of our arms" and discusses the political fractures which brought war, even though "all dreaded it." Then Lincoln asserts that slavery was the cause of the war and notes that neither side "anticipated that the cause of the war might cease with, or even before, the conflict itself should cease." In the latter portions of the address, Lincoln turns to the Bible and to God, and considers the role of the divine in both starting and potentially ending the war. He discusses prayer, and includes both direct biblical quotations and allusions to biblical passages. His audience would be familiar with both.

Both read the same Bible, and pray to the same God; and each invokes His aid against the other. It may seem strange that any men should dare to ask a just God's assistance in wringing their bread from the sweat of other men's faces; but the let us judge not that we be not judged. The prayers of both could not be answered; that of neither has been answered fully. The Almighty has His own purposes. "Woe unto the world because of offences! for it must needs be that offences come; but woe to that man by whom the offence cometh!" If we shall suppose that American Slavery is one of those offences which, in the providence of God, must needs come, but which, having continued through His appointed time, He now wills to remove, and that He gives to both North and South, this terrible war, as the woe due to those by whom the offence came, shall we discern therein any departure from those divine attributes which the believers in a Living God always ascribe to Him? Fondly do we hope - fervently do we pray — that this mighty scourge of war may speedily pass away. Yet, if God wills that it continue, until all the wealth piled by the bond-man's two hundred fifty years of unrequited toil shall be sunk, and until every drop of blood drawn by the lash, shall be paid by another drawn with the sword, as was said three thousand years ago, so still it must be said "the judgments of the Lord, are true and righteous altogether. ([18], pp. 686-87)

In the second sentence above Lincoln refers to both old and new testaments. "Bread from the sweat of other men's faces" touches base with Genesis 3:19 "in the sweat of thy face shalt thou eat bread," while "let us judge not that we be not judged" is Matthew 7:1. Directly quoted are Matthew 18:7 ("Woe unto the world because of offences!..."), and Psalms 19:9 (the judgments of the Lord ..."). Interestingly a sentence that has biblical resonance is the one that asserts "The Almighty has His own purposes." This may call to mind Job Chapter 42, where Job speaks to the Almighty "I know you can do all things, no purpose of yours can be thwarted...surely I spoke of things that I do not understand..." Lincoln's words seem to reflect his immersion in the Bible but they do not quote 
directly. Again, to the extent that his audience has been immersed in the same text, Lincoln's words can connect with them.

Lincoln takes a different attitude toward divine power in this speech than he had earlier. He doesn't claim as much knowledge of God's will as before. For example, in his December, 1862 message to Congress Lincoln talks about his way being "plain, peaceful, generous, just..." and says that it is a way that "God must forever bless." In contrast, in the Second Inaugural, Lincoln, like Job, does not claim to understand God's purposes. He argues that it is not illogical to think that God gave "both North and South this terrible war" but he doesn't assert that he knows God's purposes. God may or may not will "that it continue." Lincoln's uncertainty about God's will and purpose also comes into focus in the first phrases of the climatic last sentence (and paragraph) of the Second Inaugural: "With malice toward none; with charity for all; with firmness in the right as God gives us to see the right, let us strive on to finish the work we are in ..."

Regardless of the gloss Lincoln gives to his understanding of the Almighty's purpose, he adorns his views with his own sense that he is doing God's will, as best he can divine it. His characterization of himself as doing God's bidding, expressed in language either taken directly from scripture, or using scriptural forms and words, likely went far in creating a charismatic reaction in his audiences. At the time Lincoln's appearance, voice and demeanor may have added to that reaction. Now, only the words, the photographs and the interpretations of numerous readers and actors shape our response. For many, the response is emotional in a way that is consistent with the way Freud, Weber and others have described the impact of charismatic leaders.

\section{References}

1. Hyde Park on Hudson. Directed by Roger Michell. Screenplay by Richard Nelson. 2012, Film Four.

2. George R. Goethals, and Scott T. Allison. "Making Heroes: The Construction of Courage, Competence and Virtue." Advances in Experimental Social Psychology 46 (2012): 183-235.

3. John Keegan. The Mask of Command. New York: Viking, 1987.

4. Sigmund Freud. "Group Psychology and the Analysis of the Ego." In The Standard Edition of the Complete Works of Sigmund Freud. Edited by James Strachey. London: Hogarth, 1921, vol. 28, pp. 65-143.

5. Max Weber. The Theory of Social and Economic Organizations. Translated by Talcott Parsons. New York: Free Press, 1924/1947.

6. Gustave LeBon. The Crowd. New York: Ballantine, 1895/1969.

7. Michael Hogg. “A Social Identity Theory of Leadership." Personality and Social Psychology Review 5 (2001): 184-200.

8. Robert J. House, and Boas Shamir. "Toward the Integration of Transformational, Charismatic, and Visionary Theories." In Leadership Theory and Practice: Perspectives and Directions. Edited by Martin M. Chemers and Roya Ayman. San Diego: Academic Press, 1993.

9. Shelby Foote. The Civil War, A Narrative: Fort Sumter to Perryville. New York: Random House, 1958, vol. 1.

10. James M. McPherson. Tried by War: Abraham Lincoln as Commander In Chief. New York: Penguin Press, 2008, p. 261. 
11. Richard Carwardine. Lincoln: A Life of Power and Purpose. New York: Knopf, 2006, pp. 56-57.

12. Abraham Lincoln. "House Divided' Speech at Springfield, Illinois." In Abraham Lincoln: Speeches and Writings, 1832-1858. Edited by Don E. Fehrenbacher. New York: The Library of America, 1989, p. 426.

13. Aaron Copland. "Lincoln Portrait, 1942. Abraham Lincoln, Annual Message to Congress." In Abraham Lincoln: Speeches and Writings, 1859-1865. Edited by Don E. Fehrenbacher. New York: The Library of America, 1989, p. 415.

14. Abraham Lincoln. "Final Emancipation Proclamation." In Speeches and Writings, 1859-1865. Edited by Don E. Fehrenbacher. p. 425.

15. Abraham Lincoln. "First Inaugural Address." In Speeches and Writings, 1859-1865. Edited by Don E. Fehrenbacher. p. 224.

16. Garry Wills. Lincoln at Gettysburg: The Words That Remade America. New York: Simon \& Schuster Paperbacks, 1992.

17. Abraham Lincoln. "Address at Gettysburg, Pennsylvania." In Speeches and Writings, 1859-1865. Edited by Don E. Fehrenbacher. p. 536.

18. Abraham Lincoln. "Second Inaugural Address." In Speeches and Writings, 1859-1865. Edited by Don E. Fehrenbacher. pp. 686-87. 
Reprinted from Religions. Cite as: Ariel, Y. "Charisma and Counterculture: Allen Ginsberg as a Prophet for a New Generation.” Religions 4 (2013): 51-66.

\title{
Charisma and Counterculture: Allen Ginsberg as a Prophet for a New Generation
}

\author{
Yaakov Ariel
}

\begin{abstract}
The cultural role of Allen Ginsberg does not fit a typical Weberian model of charisma. The avant-garde poet was an outstanding personality and possessed an unusual ability to affect people. He played a vital role in expanding the boundaries of personal freedom in America of the 1950s-1990s, blazing new paths for spiritual, communal and artistic expression. Serving as a father figure for the counterculture - a symbol of an alternative set of cultural norms, lifestyles and literary forms - Ginsberg was a charismatic counter-leader, with no clearly defined followers or movement. As a leader in a more liberated era, he offered energy, ideas, inspiration, and color, but no structure or authority. Instead he was a prophet of freedom, calling on people to express themselves openly, to expand and experiment. This role demanded charisma but of a different kind-one that was more spiritual and less organizational or hierarchical. This article follows Gary Dickson's essay "Charisma, Medieval and Modern," in offering a suggestive analysis of and supplement to Weber's understanding of charisma. The article grapples with the concept of charisma in relation to a generation that resented rigid structures and authorities.
\end{abstract}

\section{Introduction}

For many Americans, the police brutality at the 1968 National Democratic Convention in Chicago overshadows all other recollections of the event. However, in the midst of the confrontations and chaos, an inspiring picture comes to mind: an American guru with long hair, surrounded by young fans and followers, singing mantras and advocating non-violence [1,2]. By the 1968 convention, Allen Ginsberg's image as a prophet for a new generation, and as a representative of an alternative set of cultural norms and spiritual practices, was well established.

Ginsberg became a symbol and a spokesperson, first for the Beat Generation, whose fame and legend he helped create, and later for the counterculture at large. As leader of the Beat literary and artistic circle, the avant-garde poet served as a central spoke that linked unorthodox writers, painters, and musicians both to each other and to larger audiences, including publishers and academic institutions. He founded and raised money for organizations and campaigns that protected the rights of writers, and he came to symbolize the struggle for free literary expression, both on account of a dramatic and groundbreaking trial and because of his constant militancy 
against restrictions on free speech. ${ }^{1}$ Ginsberg also came to represent a new wave of interest among middle-class Americans, and Westerners in general, in new forms of spirituality, helping to bring Hindu and Buddhist practices into the American mainstream. Growing up in a secular Jewish family but venturing out and expanding beyond his parents' orbit, he also stood for a new kind of Jew: one who built his or her life in a diverse and inclusive environment, chose his or her cultural interests and spiritual pursuits at will, and actively created a more complex identity than modern society had previously allowed. In all this, Ginsberg distinguished himself as a charismatic figure, inspiring new styles and drawing new and wider borders of artistic expression, all the while exploring lifestyles and spiritual sites that defied the conventional norms of mid 20th century America but became increasingly acceptable towards the turn of the 21 st century.

This essay explores the charismatic nature of Ginsberg's personality and career, as exemplified by his blazing new paths and offering new choices to individuals in late 20th century America. The article will follow Gary Dickson's essay "Charisma, Medieval and Modern," which appears in this journal, in offering an example of analyzing charismatic figures in relation to Weber's thesis, without slavishly adhering to Weber's ideas [4]. Among other things, the article grapples with the concept of charisma in relation to the Beat Generation and the counterculture, while exploring Ginsberg's central standing within his literary, artistic, and spiritual circles, as well as his influential cultural role and outstanding persona. The article will point to the elusive and problematic nature of charisma in a broad cultural movement that had neither official credos nor organizational structures or hierarchies. This study examines a charismatic cultural leader who influenced values, standards, and styles in a number of realms but did not exercise any official authority over his fans, colleagues and admirers. Likewise, he did not recruit followers into a well-defined or cohesive movement. This analysis can add an important new layer to our understanding of charisma and charismatic authority.

\section{The Growth of a Charismatic Personality}

Neither Ginsberg's personality and life choices, nor his intellectual, political, literary, and spiritual pursuits, were typical for his era and background. Trying to understand him as a product of a certain time and place will yield only partial results. Most men of his background and generation developed very differently than him. However, many elements of the poet's actions and style had their roots in a particular home, environment, and upbringing. Allen brought this background with him to the social milieux into which he ventured and on which he left his mark. Ginsberg's political stances and his advocacy of avant-garde, in-your-face, revelatory, often dissenting, poetry could be traced to the atmosphere and personalities he had encountered around him growing up.

Ginsburg's parents, Naomi and Louis, were not typical middle-class Americans of the 1920s-1940s. Both children of Jewish immigrants from Eastern Europe, they advanced through the public school system, acquiring skills and higher education, and moved away from the Yiddish-speaking, working-class world in which they grew up, into a more educated lower middle-class environment. ${ }^{2}$

\footnotetext{
1 The trial became something of a legend [3].

2 Naomi Ginsberg was born in White Russia but grew up in America.
} 
Louis was a teacher and a poet who published his poetry at his own expense, obtaining some amount of recognition and self-esteem. Yet, while the Ginsbergs were first and foremost Americans, and while both Louis' ambitions as a poet and Naomi's political activities were far from tribal, the ethnic divides of their generation imposed limitations on their mobility, and their social milieu was therefore composed mostly of secular Jews like themselves. The Ginsbergs' political views and affiliations were more radical, however, than those of most Jews (and non-Jews) at the time. Although seeing America as potentially a land of promise, they considered their country to be in dire need of social reform. Louis defined himself as a socialist, but his views were moderate compared to his wife's. Naomi was a card-carrying communist, who took Allen and his brother to events and summer camps organized by the party. She also advocated nudism and vegetarianism, both eccentric by the standards of the time. ${ }^{3}$

Although he did not adhere closely to his parents' political outlooks, Allen was certainly influenced by them. "America I used to be a communist when I was a kid/I'm not sorry," he wrote many years later in "America," a poem in which he aired his complaints and feelings about his country ([5], p. 40). While Ginsberg ventured far beyond his parents' geographical and cultural orbits, many of his attitudes and choices were inspired by his parents' values and dreams and even followed them in essence, though not in form. Ginsberg pursued what many of his contemporaries considered a radical, culturally and socially progressive worldview, and he often regarded American society and government as betraying the nation's true values and goals.

Just as important, the charismatic poet was strongly influenced by his parents' manners and attitudes. Ginsberg's mother was not afraid of adopting radical political stands and unconventional affiliations, as well as an eccentric appearance. She expressed her non-conformist opinions in an open, unabashed manner. Throughout his life, Allen would likewise demonstrate considerable defiance of social norms and disregard for rules that did not represent his values. So too as a poet and cultural leader, he spoke his mind and expressed his emotions in a direct, undiluted way (albeit, as a rule, a kind one), even if he flouted social conventions. Moreover, his constant advocacy of an open, tolerant, and inclusive society — one that would transcend tribal and parochial boundaries, allowing individuals to experience, experiment with, and create their own ways of living — also had its roots in his early life. As far removed from his parochial background as Ginsberg would become, he ultimately remained the child and grandchild of assimilationist Eastern European immigrant Jews, eager to transcend his culture of origin, and the faithful son of the radical, unconventional, and often tormented Naomi Ginsberg. Perhaps the genius of his charisma was his ability to be himself unabashedly, a bohemian, neurotic, non-conformist, East Coast Jewish intellectual, and yet become a hero and a prophet for people who came from very different backgrounds but appreciated his messages, even if they did not adopt every idea he advocated.

Circumstances became difficult for Allen and his family when his mother's mental health deteriorated. However, the pain Ginsberg carried throughout his life of having grown up with a highly unconventional, at times even psychotic, mother, ultimately allowed him to view others' eccentricities, erratic behavior, and 'craziness' as acceptable human traits ([6], p. 13). The environment in which he grew up would prepare him for his role as a leader of counter-cultural

3 For an exploration of Allen Ginsberg's family and childhood, see [6], pp. 4-32. 
groups and individuals. While emotionally damaging, his childhood experiences allowed him to feel comfortable with people with all sorts of psychological characteristics and issues. Beginning during his undergraduate years at Columbia, Ginsberg's social circle was often composed of persons 'on the edge,' and Ginsberg would share his time and space with people whom many others would have avoided on account of their marginal personalities and unpredictable behavior. Howl, one of his most powerful works, refers to friends and acquaintances who had demonstrated erratic behavior on account of mental suffering, in a way that normalizes and legitimizes their desperate actions and at the same time arouses sympathy and compassion. Dedicated to a fellow patient at a psychiatric ward in which the poet was hospitalized in 1949-1950, the poem was widely read and has touched many readers. "You have to be inspired to write like that... the right courage, and the right prophecy," Michael Schumacher wrote admiringly in 1992 ([7], p. 207). Since Ginsberg's death, a number of artists have worked on staging and filming the poem [8]. The poem is truly striking, conveying in words and rhythm both the harshness of the world and the vulnerability of humanity.

Ginsberg would soon become the leading figure of a growing circle of creative yet unconventional and, at times, self-destructive artists and writers. He possessed social energy, with both the ambition and the ability to build friendships, even with complicated personalities and literary elites who normally held themselves aloof. He acquired patrons and friends who helped him publish his, or his friends', works or aided in putting on exhibitions or concerts. Already in his college years, Allen was befriending writers and editors, gaining support and encouragement for his literary and editorial gifts. He gained the trust and appreciation of, among others, poet and literary critic William Carlos Williams, who introduced Ginsberg to fellow writers; about a decade after they became acquainted, Williams wrote a laudatory and compassionate introduction to Howl. Reading some of Ginsberg's early correspondence, one is struck by the ease with which the aspiring, but unknown, young poet approached prestigious figures in the arts and letters, making their acquaintance, offering poems or essays for publication, or inviting himself to their homes [6].

Ginsberg's ability to charm and befriend people he wished to get close to became evident when he relocated himself, geographically as well as socially, to Columbia University and the Upper West Side of New York. The young poet was eager to get acquainted with fellow students or other young people with literary and artistic inclinations, preferably from social circles and cultural backgrounds very different than his own. Within months, if not weeks, he ventured successfully beyond the ethnic and cultural confines in which he grew up in Paterson, New Jersey. Most of his new friends were non-Jews, as a rule from well-to-do middle-class white Protestant backgrounds. Many possessed physical, athletic, and social gifts, which provided them a greater sense of ease than Ginsberg in America's urban and sophisticated environment ([9], p. 21). This circle of friends was unusual for Jewish students of the 1940s, who tended to make friends with other Jews; for many of his new acquaintances, Ginsberg was the first Jew with whom they became close. This is all the more remarkable when one considers that Ginsberg was not trying to 'pass' by adopting mannerisms that were not his own or fabricating a false background. Such occurrences were not unknown among Jews of his generation. ${ }^{4}$ While he was uncomfortable with some aspects of his

4 Tobias Wolff's father was one of many such Jews who "crossed" at that time [10]. 
being, such as his homosexual desires, the aspiring poet did not pretend to be someone he was not, and his openness about himself was, at times, striking. ${ }^{5}$ Likewise, as he ventured beyond parochial constraints to obtain wider recognition, he did not befriend contacts for their money or political power, but rather for their creative and outstanding personalities or their positions in the world of arts and letters, as well as their sexual appeal and good looks. In effect, Ginsberg was struggling to create what the historian Jacob Katz called a neutral society, in which Jews like himself could work and study as well as love and live with non-Jews as a matter of course ([12], p. 195).

Ginsberg, the student, quickly gained the trust and appreciation of a number of Columbia's most outstanding men of letters, including the influential literary critic Lionel Trilling, who encouraged Allen, introduced him to editors and publishers, helped him obtain fellowships and assistantships, and wrote letters of recommendation on his behalf. Trilling and others stood at his side when he ran into trouble with the law. Few undergraduate students stirred such devotion, or received so much encouragement, from their professors.

Ginsberg was building an impressive network of connections and supporters, and he befriended a number of creative and unique personalities, including friends who would later form the core of the Beat writers and artists. However, Ginsberg could not be considered, at this early stage, a leader or a cultural hero. At this time in his life, he had other things on his mind besides promoting his and his friends' writings or promoting progressive cultural agendas - although, to be sure, those goals were already in his sights. But as a young man, Ginsberg was preoccupied with completing his studies, making ends meet, serving his time in the military, and fighting a series of emotional demons. He struggled against, then gradually came to terms with, his homoerotic feelings; also, a deep sense of guilt over his mother's loneliness and pain. His leadership position within a group that would attract national, as well as international, attention would become more evident in the 1950 s and reach its full bloom in the 1960s, with Ginsberg laboring actively to create the movement's aura.

\section{Leader of the Beat Circle}

Leadership positions, even unofficial and amorphous ones, demand great effort, and Ginsberg, perhaps somewhat unwittingly, worked hard to earn his role. To begin with, he was the one person on friendly terms with everybody else in his circle of unorthodox avant-garde writers, artists, and musicians, serving as a connecting link, and at times as a peacemaker, between feuding friends. Ironically, his tolerance of his friends' weaknesses and his willingness to put up with others' difficult personalities and psychological conditions would prove to be an asset, placing him in a central position within the group of Beat writers and artists. As a rule, Ginsberg avoided petty skirmishes with fellow writers and did not break relationships. He was in the habit of making new friends, while careful not to lose any of the older ones. Allen made a point of keeping in touch with his literary and artistic acquaintances, seeking them out, writing letters or making telephone calls to inquire about their well-being. He often made tours, or stopped by along the way, to revive or keep old friendships going. Also, he kept his home open to friends with artistic inclinations, whether for them to stop by or to reside for short or long periods of time. He extended this hospitality to friends

5 See, for example, Ginsberg's letter to Wilhelm Reich, March 11, 1947 ([11], pp. 16-17). 
or colleagues whom other acquaintances, such as Bill Morgan, considered obnoxious ([6], pp. 533-36). Among these was Jack Kerouac, who at times turned so hostile and abusive that keeping in touch with him demanded great forbearance. Ginsberg thus developed and maintained friendships with a constantly growing number of colleagues in the arts and letters, establishing an expanding circle of creative, if not always easy-going, personalities.

The constant outpouring of energy and patronage towards the careers and lives of others helped turn him into a leader able to bring together individuals who otherwise may not have cooperated with each other. He organized or recruited fellow writers and artists to appear at different events, including poetry readings; concerts; sessions of summer school at Naropa University in Boulder, Colorado, which he helped establish; or lectures series at Brooklyn College, where he began teaching in the late 1970s. Much of Ginsberg's charisma in literary circles flowed from his role as a mediator, promoter, and initiator of such projects, as well as a willing agent and impresario for many of his acquaintances. He spent much time and energy using his connections to help others in his circle publish, perform, or exhibit, and he helped a number of writers and painters launch careers and receive recognition. At times he offered financial support to needy friends and colleagues.

Among the beneficiaries of Ginsberg's at times seemingly unilateral good will was Jack Kerouac, who was to become the most popular novelist of the Beat generation. Written in an associative open-ended prose, his best-selling novel On the Road was to achieve a mythical aura. But for long years, Ginsberg tirelessly advocated the publication of the book, struggling to find it a publisher, and telling editors, critics, and journalists that Kerouac's was one of the world's greatest novels. ${ }^{6}$ Ginsberg also helped William Burroughs and Neal Cassady, other central figures in the group, to publish their books. In Burroughs's case, Ginsberg also worked to turn Burroughs's book, Naked Lunch, into a publishable manuscript. Granted, Ginsberg was devoted to his friends, at times in love with them, and he considered Kerouac and Cassady especially attractive and charismatic personalities ([9], p. 21; [13], p. 68). However, his promotion of his friends' literary products went beyond personal attachment. By assisting individual colleagues, Ginsberg was promoting his literary circle at large and its standing within the larger culture. His own aura grew as he boosted the creativity, reputation, and careers of friends and acquaintances. Helping build Kerouac's or Cassady's careers reflected on him and his own project. Associated, at first, with City Lights Books in San Francisco's North Shore, which also published Ginsberg's early books, the Beat group, now often dubbed Beatniks, stirred growing interest and recognition. Ginsberg, perhaps more than any other member of the group, also helped create its mystique [14]. The reputation of the group, never organized or united, grew considerably. A long series of 'I-knew-those-guys' or 'I-was-part-of-the-group' autobiographies and recollections began to appear as early as the 1960s, often written by persons playing secondary roles within Beat circles, attesting to how early the Beat aura and mystique developed [15-22]. On his own, without the growing interest in the Beat movement, Ginsberg would probably have received less attention and recognition than he did as

6 The index in Morgan's biography of Ginsberg [6] includes a special entry "Ginsberg's promotion of" [Kerouac's writings], referencing 20 different pages in the biography. Kerouac's biographer, Tom Clark, plays down Ginsberg's contributions [13]. 
the representative of a legendary group that within a few years came to serve as the flagship of a larger countercultural movement in America and beyond.

Max Weber acknowledged that charisma, in spite of its ur-etymological definition, was not a gift of the gods but a social construction, often working from the bottom up ([23], pp. 56-77). Gary Dickson brings up to date the meaning of charisma, pointing out that since the 1960s the word has been applied not only to political or religious leaders, but also to cultural icons ([4], pp. 3-4). ${ }^{7}$ While Ginsberg possessed character traits that turned him into a central figure and leader of a loosely organized literary and artistic group, his career illustrates that charisma can derive, at times, from the aura a movement reflects onto its leaders and noted personalities. Ginsberg's charisma and leadership role would reach broader venues and new heights when he came to represent a larger cultural movement and, for some, an entire era and generation that pursued new or alternative spiritual and value systems.

\section{A Literary and Cultural Icon}

Following the publications of Howl (1956) [24], and Kaddish (1961) [25], Ginsberg became an established, increasingly recognized poet. The growing public interest in the Beat group and its writings promoted Ginsberg's reputation beyond appreciation for his poetry. By the early 1960s, interest in the literary styles of the Beat circle grew considerably, and its writings were soon to become associated with the generation at large. The Beat writers were making their way into mainstream bookstores, as well as into literary magazines, university syllabi, and research papers and theses. Literary circles and the academy increasingly recognized the Beat generation as an important group of writers and artists, a development that affected Ginsberg's growing fame and prestige, leading to public readings, lectures, essays in newspapers and literary journals, museum exhibitions, plays, and movies.

Acquiring and utilizing charisma requires, as Ginsberg's schedule suggests, dedicating substantial time and energy to multiple public projects and satisfying popular requests and inquiries; the charismatic poet was more than ready to make the effort. Allen enjoyed giving interviews, talks, and seminars, making himself constantly available for reading events, symposia, lectures, interviews, and correspondence. The poet used the ever-growing number of such forums to present his poetry, as well as his literary, spiritual, and political outlooks.

Among other agendas, Ginsberg wished to promote his style of poetry, which he considered appropriate for his times and values. Influenced in part by William Blake, Walt Whitman, and William Carlos Williams, he stepped beyond early influences to create and promote his own voice. Ginsberg advocated a direct style of poetry, fully in tune with poets' feelings and observations, regardless of social norms and poetic traditions. Ginsberg's instructions to poets can be found in "Written in My Dream," a poem he wrote on the topic.

As is / you are bearing / a common / truth / commonly known / as desire / No need / to dress / it up / as beauty / no need / to distort / what's not / standard / to be / understandable / pick your / nose / eyes ears / tongue / sex and / brain / to show / the populace / Take your / chances / on / your accuracy / Listen to /

Please note also Dickson's critique of Weber's understanding of charisma. 
yourself / talk to / yourself / and others / will also / gladly / be relieved / of the burden- / their own / thought / and grief. / What began / as desire / will / end / wiser. ([26], pp. 357-58)

Not all poets dedicate poems to instructing readers in a new school of poetry. However, many of Ginsberg's poems, including the better-known ones, were instructive in nature, promoting awareness of aspects of life, feelings, and creativity that Ginsberg considered ignored or misunderstood. "Written in My Dream," composed relatively late in Ginsberg's career, became a central piece in his reading tours; it was recorded and even sung. ${ }^{8}$

Following his trip to India in 1962, Ginsberg made a habit of starting his literary performances and public talks with the chanting of mantras, at times resorting to such singing when literary or political events went sour and disagreements or disturbances erupted. This was the case in August 1968, when the Beat poet, by that time a convinced pacifist, tried to calm the heated spirits in Grant Park, Chicago, by his reciting of such hymns. Allen also adopted the habit of introducing younger or lesser-known poets by inviting them to read alongside him, even when they were not scheduled to speak and the organizers had no prior knowledge of these additions to the program. In this way, he used his reputation to help aspiring new poets launch or enhance their careers. Such a posture helped strengthen his role as a central brotherly and fatherly figure of his group, further building his charismatic aura.

Early on in his career as a poet and public speaker, Allen decided to dedicate the income he received from lectures and reading tours to his various public causes. Ginsberg was in his element on the stage, inspiring his audience. Reading poetry is an art, which Ginsberg mastered to perfection, creating an atmosphere that matched his personality and poetry. ${ }^{9}$ From the late $1950 \mathrm{~s}$ until his death, he gave hundreds of poetry readings, some of which yielded handsome incomes. One of the major beneficiaries from the income from Ginsberg's poetry readings was the Committee on Poetry, a nonprofit organization Ginsberg founded in 1966, which offered material and legal support to fellow poets and colleagues, as well as cultural rebels such as Timothy Leary, who became entangled in legal battles. This commitment provided Ginsberg with an additional leadership edge. In the case of Leary, he was now associated, in people's minds, with the call to experiment with drugs.

In the late 1960s, Ginsberg assumed a more influential cultural and political role, becoming a father figure for the much larger countercultural audiences that during that time adopted many of the Beat generation's values and styles, from more daring expressions in literature to explorations of new spiritual paths. In this capacity, too, Ginsberg often acted as a mediator and peace maker. In recordings of countercultural discussions and symposia, one can hear Ginsberg express more moderate views and optimistic assessments than other speakers, often trying to soften other's

8 One of Ginsberg's last powerful poems, Written in a Dream, appeared in a technological age and can be found online set to music or special graphical designs. See a snippet of Ginsberg's own reading of the poem on September 16, 1993, www.youtube.com/watch?v=Kt3pj8JFCII.

9 I owe thanks to a number of colleagues and friends for sharing their impressions of Ginsberg with me. Nora Rubel attended his last performance at Carnegie Hall, which took place a short time before he died, and was amazed by Ginsberg's vitality and charisma. She realized how weak he had been only when she met with him after the concert [27]. 
heated exclamations. ${ }^{10} \mathrm{He}$ made an impact on countercultural positions and habits with his more peaceful opinions and less flamboyant language.

\section{Countercultural Charisma and Sex}

Ginsberg's charismatic gifts and his ability to bring people into his orbit manifested themselves strikingly in the sexual realm. Ginsberg's sexual explorations were tied together with his talent to influence people's lives and further interwoven with his literary and spiritual messages. In all of these realms, he called for openness of heart and mind, generosity of spirit and flesh, and a revealing and liberating self-expression. He voiced his sexual mores in his poetry and in his readings and encouraged colleagues to be open in their poetry, including their public readings. In judging the poetic quality of fellow writers, artistic expressions of intimate matters became a litmus test for him. When Denise Levertov's poetry became more daring and revealing, he felt that he could find a common language with her and could relate to her more appreciatively as a friend and a poet ([6], p. 377).

Carnal attachments were important to Allen, providing more than an outlet for his libido. With his growing acceptance of his homoerotic tendencies, his attitudes towards physical explorations became more proactive than before. He saw unity of flesh as a means of bonding; through intimate acts, he sought others' approval and affirmation. Sexual encounters offered redemption and self-validation no less than spiritual exercises or pilgrimage to holy sites. In this realm, as well, Ginsberg served as a prophet for a new age, in which the right to individual fulfillment was more important than adherence to traditional norms. Ginsberg was not shy about conveying this idea to friends (mostly men) with whom he fell in love, arguing for amorous intimacies as a means of signifying and solidifying emotional attachments ([6], p. 189).

Ginsberg's encounters with both sexes showed him to possess an almost magical touch that enabled him to charm both men and women to the point of drawing them to either seek or accept his sexual company. As a rule, the women in his life sought his intimacy more than he pursued theirs, at times hoping to establish a long-term relationship and perhaps build a family together. This interest on the part of Ginsberg's female friends persisted even when it became evident that he was not interested in sharing his life with women. In spite of Ginsberg's gay tendencies, relationships with women, as well as men, were often kindled quickly. At times, a chance encounter at a party, or a reading event, or a literature class, could ignite attractions and romances.

Bill Morgan points out that Ginsberg was not attracted to gay men and that when confronted with gay pursuers he would rebuff them ([6], pp. 120, 189, 391, 538, 569). Perhaps because he had a hard time accepting his homosexuality and for a time made deliberate efforts at establishing 'straight' relationships, Ginsberg found straight 'manly' men more desirable. ${ }^{11}$ Amazingly, he managed to have numerous intimate encounters with men who did not identify as gay, did not lead gay lives, and were, for the most part, involved with women throughout their lives. This included even his lifelong friend Peter Orlovsky. Ginsberg's male lovers often had other intimate

10 See the transcript of “The Houseboat Summit," February 1967, reprinted in [28], pp. 271-301.

11 Steven Taylor suggests that Ginsberg's attraction to handsome, manly, athletic, and popular men was due to such men being very different from himself ([9], p. 21). 
attachments already, even marriages. That he managed to persuade such acquaintances to overcome their (often life-long) disinterest in or even aversion to same-sex encounters should be attributed to outstanding energies of persuasion and an ability to affect other people's choices, especially in one-on-one encounters. As time went by and Ginsberg's reputation grew, men much younger than he (and occasionally women) entered his romantic life. While Allen's ability to successfully pursue his objects of desire became evident early on, in this case 'charisma' proved its presence in his multiple encounters with individuals he met.

\section{A Prophet of New Identities and Spiritualties}

One of the major components of Ginsberg's charismatic position in countercultural circles was his role as a pioneer in the new spiritualities that Americans have adopted and adapted since the 1960s in much larger numbers than before. Ginsberg signified a new era of spirituality centered around the choices, journeys, and needs of individuals. His experience of mystical moments, related to different cultural and religious settings, defied the common wisdom of scholars of mysticism who worked in the early decades of the 20th century, among them Gershom Scholem ([29], esp. first lecture). Scholem, a thoroughly modernist thinker who promoted Jewish particularity, asserted that mystical experiences occur only within the cultural-religious framework in which the individual mystic grows up and lives his or her life. According to that paradigm, Allen should have encountered Elijah, an acceptable revelation, according to Scholem, for persons growing in a Jewish environment. The charismatic poet, however, encountered William Blake in a moment of revelation-without ever having converted to Christianity. Ginsberg's experience with Blake represented not a change of loyalties and communal affiliation but rather the incorporation of elements of Christian spiritualities, in this case English Protestant apocalyptic imagery, into the growing amalgam of a constantly enriched inner life. In this regard, Ginsberg was a forerunner and prophet for a postmodern era, in which individuals select and combine their spiritual interests. Ginsberg ventured throughout his life to broaden his spiritual horizons in addition to his emotional, intellectual, aesthetic and literary experiences. He was a perpetual pilgrim, thus providing a role model for the many individuals who in the decades since have come to pick and choose their spiritual paths and religious networks, shifting and re-arranging them along the way, or amalgamating different traditions, practices, and identities to suit their emotional and communal needs. Ginsberg's spiritual odyssey is worth exploring, given that it served an entire generation as a model for the relationship among individuals, communities, and religious traditions, old and newly adopted.

Ginsberg grew up in a secular Jewish home, not committed to observance of the commandments or the studying of Jewish texts. But even this seeming spiritual void left a deep mark on Allen. The family did celebrate Passover seders, often with relatives. Some of the language and rhythm of epic passages of the Passover Hagaddah are echoed in Howl, except that the "He" of whom Ginsberg speaks in Howl refers to vulnerable humans instead of to God. The family also followed some Jewish rites of passage, notably Jewish funerals and the reciting of kaddish, the traditional Jewish mourner's prayer. Allen was absent when his mother, Naomi, died and did not attend her funeral. The few mourners who did participate refrained from reciting the kaddish. Years later, a pained Allen wrote his second major poem, Kaddish, as a substitute for the kaddish not recited for his 
mother. The poem follows Howl in its themes and atmosphere, as befits a memorial poem to the emotionally tormented Naomi Ginsberg, whose misery and loneliness, especially after she left the family home, burdened her son's conscience. When writing Kaddish in 1960, Allen was far from leading a Jewish life. He had no affiliation with Jewish congregations or groups, although he took some interest in Jewish spirituality and related strongly at times to Jewish history and symbols. ${ }^{12}$ It was important for him to commemorate his mother by reciting belatedly, and in a literary form, an individualized version of the Jewish prayers traditionally recited for one's beloved dead. Ginsberg's Kaddish follows the powerful rhythm, though not the words, of the traditional prayer. The mostly Aramaic prayer affirms the majesty of God in the face of loss and grief, without reference to the deceased, the specifics of his or her life, or to the bereaved family. Ginsberg postmodernized the ancient prayer, personalizing it and tailoring its content to his mother's life experiences, while maintaining its powerful effect and its connection to realities beyond the life of the deceased. As an individualization of the ancient prayer, Kaddish simultaneously maintains a universal message. The poem appealed to many Jews of Ginsberg's generation, who appreciated, in addition to the powerful poetic elements, its value as a model of personalized commemoration. Perhaps unwittingly, Ginsberg served as a Jewish reformer, giving a voice to many Jews of his generation who considered the traditional Jewish prayer to be too remote and abstract.

Few view Allen Ginsberg as a Jewish leader. He himself would probably have disliked that characterization. However, while he did not act directly on behalf of Jewish communities, and while Jews of his time failed to recognize him as an avant-garde explorer of new Jewish practices and identities, Ginsberg served as a forerunner of a new type of Jew in the postmodern world. Kaddish was a hit among educated Jews and could be found, during the 1960s-1980s, on the bookshelf of almost every Jew who read poetry. Nathan Zach, one of Israel's recognized poets and himself an icon of a new individuality in Israel, translated Ginsberg's poetry into Hebrew, helping acquaint Israeli audiences with the American poet. Perhaps without realizing it, Ginsberg opened the way for a number of Jewish writers to invest the kaddish with new spiritual meanings [30,31].13

His relationship with his Jewish family also pointed the way to new interactions in many Jewish (and non-Jewish) families. Ginsberg maintained a warm relationship with his Jewish relatives throughout his life. ${ }^{14} \mathrm{He}$ also took keen interest in Jewish history and mysticism, identified with Jewish suffering, and visited the new Jewish state. ${ }^{15} \mathrm{He}$ refused, however, to limit himself to Jewish cultural, communal, or religious venues. Instead, he stitched them into an ever-growing quilt of cultural, religious, and aesthetic influences that Ginsberg took from and contributed to an increasingly pluralistic social milieu. Ginsberg thus foreshadowed a new kind of Jew of the late 20th century: one who explores new spiritual homes or amalgamates different experiences and cultures. Among his contributions, Ginsberg served as a catalyst and symbol for the relatively large number of Jews who have become practitioners of Asian or other faiths while maintaining their

12 When outside of the United States, Ginsberg made efforts to visit sites with Jewish historical meaning. See, for example, Allen Ginsberg's letter to Nicanor Parra, August 20, 1965 ([11], p. 303).

13 Wieseltier's Kaddish [30] explores the history and meaning of the ancient prayer, intermingled with the author's experiences during his year of mourning his father.

14 See the photograph "Allen Ginsberg family," a reunion on 31May 1970, taken by Richard Avedon, [32].

15 For example, Allen Ginsberg to Eugene Brooks, November 25, 1961 ([11], pp. 252-54). 
Jewish identity. Jewish practitioners of Buddhism increased considerably during the 1970s-2000s, with thousands of Jews joining Buddhist groups, including in Israel [33].

Ginsberg's social circle was one of the first of its kind to open up to Jews as colleagues, friends, and lovers, with little or no stigma attached. This innovation was insightfully identified by Jack Kerouac, who strongly related to Ginsberg's Jewishness both negatively and appreciatively. Kerouac saw his friend's ability to become an influential figure within a larger cultural movement as pointing to a new phase in the position of Jews within American society, and he lamented the Jewish community's lack of recognition for Ginsberg's role. ${ }^{16}$ "It's most important for you to realize that...the Jews are bound to neglect their own best Ginsberg Jesus, the prophet is without honor..." ([34], p. 288).

Until his travels with Peter Orlovsky to India in 1962, Ginsberg's spiritual interests moved in the Jewish-Christian path, with the poet showing more interest in Christian mysticism, perhaps, than in Jewish. He was attracted, for example, to the mysticism of St. Francis of Assisi. Ginsberg's poetry invokes the Jewish-Christian God time and again, albeit revolutionizing the meaning of righteousness and holiness. "Holy Holy Holy," which accompanies Howl, is a good illustration of Ginsberg's deeply religious poetry, a poetry which is at the same time defiant and striking, even shocking, by the standards of the day, calling for a new understanding of humans, their emotional needs, and their personal rights.

Deborah Baker points to Ginsberg's visit to India in 1961-1962 as a transformative period in his life [35]. ${ }^{17}$ While Ginsberg and Orlovsky joined poet Gary Snyder and wife Joanne in exploring India and its spiritual venues, it was Ginsberg who would come to symbolize Americans' new enchantment with Asian religions. Writers who discuss the growing interest in Asian religions among educated middle-class Americans bring up Ginsberg as one of the early examples and an outstanding figure who led the way for others ([37], pp. 235-41). This is especially true for Ginsberg as a forerunner of Jewish interest in Buddhism. Here again, Ginsberg was not a conventional charismatic figure. His spiritual pilgrimage, alongside those of other icons of the counterculture, served as a model and an inspiration, but the poet himself did not create a new group or even call upon Americans to join a particular movement, not did he turn himself into a guru as did some other members of his generation. Moreover, his spiritual path was not tied to one idea or group and was eclectic and multi-faceted.

At the height of the psychedelic years, after his return from India, Ginsberg became a symbol of the use of drugs as a means for spiritual growth and inner peace. Ginsberg used recreational drugs before the 1960s, like many of his friends and acquaintances, although he made certain not to become addicted and, as a rule, refrained from long-term usage of hard drugs. However, in the 1960s he became associated with LDS ideologue Timothy Leary, a role in which he influenced many spiritual seekers in the 1960s and 1970s [28]. In this he was not alone. A series of countercultural religious leaders from Ram Das to Zalman Schachter-Shalomi experimented with drugs as a means of expanding their minds and spirits and gaining new perspectives on themselves

16 Jack Kerouac to Allen Ginsberg, May 11, 1955 ([34], pp. 287-89).

17 See also Ginsberg's poetry and letters of the period ([36], pp. 290-322; [11], pp. 256-87). The references to Ginsberg's writings include poems and letters from Japan, which was also an important station along the way. 
and the world in its multiple dimensions. Ginsberg's role as a leading symbol of that movement contributed to his aura as a prophet of spiritual experimentation and personal liberation.

Ginsberg advocated some Hindu practices, as he understood them, including pacifism, a teaching central to his aura as a prophet for the Vietnam Era generation. It was in the mid-1960s that Ginsberg discovered Buddhism. He did not undergo a conversion experience, did not follow any orthodoxy, and did not tie himself to one school or interpretation. His was a tailor-it-to-yourneeds Buddhism, in which he alternated among teachers and systems that suited him best. His Buddhist practices and affiliations notwithstanding, Ginsberg maintained Hindu practices, as well as related to Jewish history and symbols such as the wailing wall in Jerusalem, and his poetry continued to reflect a strong Jewish-Christian cultural awareness. ${ }^{18}$ While on some levels his Buddhist path was private and self-customized, Ginsberg became nonetheless an icon of the new wave of interest among educated middle-class Americans in Asian religious teachings. For Jews he was the BuJew par excellence. Ginsberg participated actively, and assumed leadership roles, in a number of Buddhist groups and projects. Utilizing his position in his circle of American writers, Ginsberg also established the Kerouac's Center for Literature at Naropa University in $1974 .{ }^{19} \mathrm{He}$ recruited a long series of fellow writers to teach in the program and raised funds. It is noteworthy that instructors, among whom were leading men of letters, were not paid but merely provided with dormitory space. These individuals were not necessarily philanthropists, and many of them could have used an honorarium. It took Ginsburg's strong relationships and gifts of persuasion to bring this gallery of accomplished writers to Naropa every summer. Directing the program also allowed Ginsberg to exercise his charms on a younger generation of students and writers, establishing both literary and intimate contacts. No less important than offering leadership, fundraising, and helping establish centers and projects was the prominent public image Ginsberg provided to the larger Buddhist-American movement, associating it with the counterculture and with an emphasis on individuality and self-fulfillment.

Ginsberg's interest in Buddhism often mixed with other projects and pursuits. Besides creating in Naropa a center for writing and a venue for literary creativity and exchange, the poet took part in the "return to nature" movement of the " $60 \mathrm{~s}$ and ' $70 \mathrm{~s}$ and the building of agricultural communes. ${ }^{20}$ In this experiment, Ginsberg was the initiator, funder (from his own income, primarily), and community leader. Gordon Ball tells the history of East Hill Farm in upstate New York as a story of both triumph and failure. Ginsberg was interested in creating a spiritual retreat for himself and his friends, as well as offering a site for rehabilitation to acquaintances, including Peter Orlovsky, who were struggling with drugs and other addictions. Reading Ball's memoir, one is struck by Ginsberg's central role in creating a small community of farmers and spiritual seekers. There were other intelligent, resourceful, and impressive personalities involved, including Ball himself [41]. But the commune was dependent on Allen's leadership (and finances) for survival. He was the only one capable of navigating among the different characters, making peace, and cultivating a sense of

18 Surprisingly, the multi-faith influences on Ginsberg and his own multi-faith practices came up in the Chicago Seven Trial (December 11-12, 1969), where he was a witness for the defense. Note his answers about his faith practices ([38], pp. 201-04).

19 On Ginsberg as a leader in Naropa, see [39].

20 On the movement, see [40]. 
unity and purpose. Ginsberg was, however, a very busy poet, performer, mystic, free-speech crusader, impresario, anti-war activist, and founder of Buddhist centers and projects, to name merely his central activities. The East Hill Farm commune was Ginsberg's child, and it died when it became evident that he did not have the time and resources to continue leading the experiment (see also [6], pp. 432-504).

\section{Conclusions}

Allen Ginsberg's career is not a typically Weberian study in charisma. As with so many other components of his personality, activity, and creativity, Ginsberg possessed his own kind of charisma. The avant-garde poet was undoubtedly an outstanding personality with an unusual ability to influence people. Dynamic, creative, original, daring, and brilliant, he became a central figure in almost every group he joined or established. His merits, however, would not have risen to the status of "charisma" were it not that the social, cultural, literary, and intellectual environments were ready for his voice and ideas. At other times and places, Ginsberg's personality would not have sufficed to make him a cultural icon. He might have ended on the gallows, in a gulag, or in a mental asylum. Merely a few years earlier, Ginsberg's life would have taken a very different turn, and he would probably not have been able to pursue the cultural role he fulfilled between the 1950s and the 1990s. The age was barely ripe to, first, tolerate and then accept Ginsberg, allowing him to become a literary, cultural, and spiritual icon. He himself played a vital role in expanding the boundaries of personal freedom and self-expression and promoted his own aura and career in resourceful ways. But his successes tell us about the times even more than about this cultural leader. Eager to influence the culture and values of his era, Ginsberg was fully aware of developments around him. He realized that the generation of the 1960s-1970s had no interest in the kind of leaders and movements that appealed to his parents' generation, and he spoke about the "genius of non-leadership" ([38], p. 276). By this he did not mean an absence of charismatic figures to led the way, but an avoidance of the authoritative and intellectually and spiritually repressive leaders of political, ideological, and religious movements of the previous generation. He himself served as a charismatic counter-leader: with no clearly defined followers, he offered energy, ideas, inspiration, color, and a symbol for a more liberated and diverse era. He was a prophet of the freedom to be truthful to oneself, to explore, expand, and experiment. This demanded charisma, but of a different kind-more spiritual and less organizational or hierarchical. His charisma matched the countercultural movement perfectly. 


\section{References}

1. Todd Gitlin. The Sixties: Years of Hope, Days of Rage. Toronto: Bantam Books, 1987.

2. John Schultz. No One Was Killed: The Democratic National Convention, August 1968. Chicago: University of Chicago Press, 1999.

3. "Howl: The Obscenity Trial that Started a Revolution." Directed by Rob Epstein, Jeremy Friedman. Minneapolis: Werc Werk Works, 2010. Film.

4. Gary Dickson. "Charisma, Medieval and Modern." Religions 3, no. 3 (2012): 763-89.

5. Allen Ginsberg. Howl and other Poems. San Francisco: Lights Books, 1959.

6. Bill Morgan. I Celebrate Myself: The Somewhat Private Life of Allen Ginsberg. New York: Penguin, 2006.

7. Michael Schumacher. Dharma Lion: A Biography of Allen Ginsberg. New York: St. Martin's Press, 1992.

8. Simon Warner, Ed. Howl for Now: A Celebration of Allen Ginsberg's Epic Poem. Pontefract: Route, 2005.

9. Steven Taylor. "The Poem and I are Fifty." In Howl for Now. Edited by Simon Warner. Pontefract: Route, 2005.

10. Tobias Wolff. In Pharaoh's Army: Memoirs of the Lost War. New York: Knopf, 1994.

11. Allen Ginsberg. The Letters of Allen Ginsberg. Edited by Bill Morgan. Philadelphia: Da Capo Press, 2008.

12. Jacob Katz. Out of the Ghetto. Tel Aviv: Am Oved, 1985.

13. Tom Clark. Jack Kerouac: A Biography. New York: Marlowe and Company, 1984.

14. Carolyn Cassady. Off the Road: My Years with Cassady, Kerouac, and Ginsberg. London: Black Spring Press, 1990.

15. Thomas Parkinson, Ed. A Casebook on the Beat. New York: Crowell, 1961.

16. Gregor Roy. Beat Literature. New York: Monarch, 1966.

17. Diana di Prima. Memoirs of a Beatnik. New York: Olympia, 1969.

18. Jane Kramer. Allen Ginsberg in America. New York: Random House, 1969.

19. Thomas F Merill. Allen Ginsberg. New York: Twayne, 1969.

20. Eric Mottman. Allen Ginsberg in the Sixties. Brighton: Unicorn, 1972.

21. Allen Young. Allen Ginsberg: Gay Sunshine Interview. Bolinas: Grey Fox, 1974.

22. John Tytell. Naked Angels: The Lives and Literature of the Beat Generation. New York: McGraw-Hill, 1976.

23. Max Weber. The Theory of Social and Economic Organization. New York: Free Press, 1964.

24. Allen Ginsberg. Howl, and Other Poems. San Francisco: City Lights Pocket Bookshop, 1956.

25. Allen Ginsberg. Kaddish, and Other Poems, 1958-1960. San Francisco: City Lights Books, 1961.

26. Allen Ginsberg. Selected Poems 1947-1995. New York: Harper Collins, 1996.

27. Author's Personal Conversation with Nora Rubel, Chicago, 18 November 2012.

28. Peter Conners. White Hand Society: The Psychedelic Partnership of Timothy Leary and Allen Ginsberg. San Francisco: City Lights Bookstore, 2010.

29. Scholem, Gershom G. Major Trends in Jewish Mysticism. New York: Schocken, 1961.

30. Leon Wieseltier. Kaddish. New York: Knopf, 1998. 
31. Kate McLoughlin. "Dead Prayer? The Liturgical and Literary Kaddish." Studies in American Jewish Literature 25 (2006): 4-25.

32. Richard Avedon. "Allen Ginsberg family." The New Yorker, 21 May 2012, p. 52. Photo.

33. Joseph Loss. "Buddhism-Dharma in Israel: Explicit Non-Religious and Implicit Non-Secular Localization of Religion." Nova Religio 13, no. 4 (2010): 84-105.

34. Bill Morgan, and David Sanford, Eds. Jack Kerouac and Allen Ginsberg, The Letters. New York: Viking, 2010.

35. Deborah Baker. A Blue Hand: The Tragicomic, Mind Altering Odyssey of Allen Ginsberg, a Holy Fool, a Rebel Muse, a Dharma Bum, and His Prickly Bride in India. New York: Penguin, 2008.

36. Allen Ginsberg. Collected Poetry, 1947-1980. New York: Harper Perennial, 1984.

37. Roger Kamenetz. The Jew in the Lotus: A Poet's Rediscovery of Jewish Identity in Buddhist India. New York: Harper Collins, 1994.

38. David Carter, Ed. Allen Ginsberg, Spontaneous Mind: Selected Interviews 1958-1996. New York: Perennial, 2001.

39. Sam Kashner. When I was Cool: My Life at the Jack Kerouac School. New York: Harper Collins, 2004.

40. Timothy Miller. The 60s Religious Communes: Hippies and Beyond. Syracuse: Syracuse University Press, 1999.

41. Gordon Ball. East Hill Farm: Seasons with Allen Ginsberg. Berkeley: Counterpoint, 2011. 
Reprinted from Religions. Cite as: Lehmijoki-Gardner, M. "Charisma, Diversity, and Religion in the American City_A Reflection." Religions 5 (2014): 435-443.

\title{
Charisma, Diversity, and Religion in the American City- A Reflection
}

\author{
Maiju Lehmijoki-Gardner
}

\begin{abstract}
The faith leaders of North American cities actively engage in the civic affairs of their urban communities. Religious leadership, charismatic preaching, and, possibly, reputation of prophetic powers, continue to play important roles especially in the African American civic leaders' rise to public authority. The article reflects on the twenty-first-century significance of Max Weber's concept of "charisma" in interpreting the civic involvement of urban religious leaders in one city in particular, Baltimore. The article suggests that within the context of Baltimore's dramatic challenges associated with urban poverty, violence, and racial and socio-economic health disparities, charismatic religious leadership continues as a recognized form of communal authority especially among the city's African Americans. The article suggests that the gender dynamics of contemporary charismatic leadership appears strikingly similar to another time period and place, also analyzed by Weber - namely, medieval Europe. Just as an intense personal faith granted some medieval religious women authority and position they would not have had in the institutions reserved for men, so too the religious leadership and personal experiences of faith support the urban advocacy of African American women leaders.
\end{abstract}

\section{Introduction}

Religious communities and people of diverse faiths are integral to the culture of American cities. While The Pew Research Center's Religious Landscape Survey, conducted in 2007, showed that on average the urbanites, especially the young ones, are less religious than their counterparts in suburbs, small towns, and rural America [1], the observation should not be taken to mean that faith communities are marginal to the American urban experience. To the contrary, the churches of various denominational backgrounds shape the urban landscape, both visually and functionally, around the world [2] but especially in the United States. The faith communities and their outreach centers are part of all neighborhoods and appear to rise up at nearly every stretch of a street in the North American cities. These edifices rub shoulders with one another and with enterprises of completely different sort, schools, and commercial establishments, even corner stores specializing in liquor, tobacco, and fatty snack foods. Competition for attention is intense within this context of diversity and innovation; movements of secular and religious sort rise and fade, and the churches look for survival strategies that borrow methods from the world of commerce [3]. 
The backdrop of diversity, community building, and socio-economic uncertainties sets the tone for this reflection on the place of religious charisma in a twenty-first-century American city, Baltimore. The colorful urban landscape of American religious diversity and innovation has received rich treatments by scholars such as Harvey Cox [4], Robert Orsi [5], and Diane Eck [6]. My contribution rests upon the scholarship concerning urban religious cultures but does not represent years of bibliographic research on this topic. Rather, this reflection is a scholar's examination of a country and a field fairly new to her. I am a Finn who immigrated to the United States eighteen years ago, and I am a medievalist who, after years of research and teaching in late-medieval religious movements, began another career uniting urban health issues, nursing, and the study of religious traditions. My earlier research and teaching concerned social aspects of medieval women's sanctity [7], prophetic women and institution building [8], and religious lay movements [9] — and, much to my surprise, some of these perspectives have proven quite helpful for understanding urban religions, their social relevance, and the place of charismatic leadership within them.

On the other hand, the contribution of my Scandinavian background has come through contrast, for often the strategies for urban health care that are employed around Baltimore are not the ones to be expected in Finland. In Finland the faith-based promotion of public health is virtually unheard of; in Baltimore diverse faith communities are actively engaged in civic and health issues, as I came to witness during my time of going around the city and writing the blog Health and Faith in Baltimore (2011-2013) [10]. I now educate college students in these issues through my service-learning classes. In these classes the students head out to do health-related community service and then bring their experiences back to the classroom to connect the community work with the course readings. In today's secular and modernist Finland the prophetic and spirit-filled charismatic authority is limited to the internal operations of some Pentecostal communities; in Baltimore, and especially among the city's African American faith communities, I would argue, spiritually visionary leadership continues to be relevant religiously, socially, and politically.

\section{Weber in America}

The multiculturalism of American faith communities comes with nuanced and, at times, competing social visions through which the religious establishments promote their particular understandings of communal life. The prominent social role that religious institutions play in the American cities did not escape the attention of Max and Marianne Weber when they visited the United States in 1904. Lawrence Scaff has examined the Webers' three-month-long American sojourn in his recent book Max Weber in America [11]. The couple's trip occurred within the context of the World Fair in St. Louis and the associated International Congress of Arts and Science. At the invitation of some relatives and many academic institutions the Webers ventured to a few remote rural sites in Alabama and North Carolina, and cities such as Boston, New York, and Washington. Explorations to diverse faith communities were part of the agenda; at times Max and Marianne Weber divided the communities so that they could maximize their exposure to practices of various churches as well as "sects", as Weber named the less formalized religious establishments ([11], pp. 29-38). During the sojourn of 1904 Weber's attention was focused, as Scaff aptly makes clear, on American modernity, individualism, community organizing, and the economic impact of 
religious associations ([11], pp. 161-80). The question of prophetic, religious charisma was not yet the vogue word that it came to be in Max Weber's work from the 1910s onward.

The later popularity - and popularization - of the concept of "charisma" among American political and religious theoreticians paid tribute to Weber's observations of America's religious plurality and innovation as well as social relevance of spiritual traditions. As Joshua Derman has argued in his article "Max Weber and Charisma: A Transatlantic Affair", the popularized concept of "charisma", akin to religious star-power, found its way to American social theory only after a long process ([12], pp. 87-88). Derman demonstrated that initially the American political theoreticians used the Weberian concept of "charisma" to address the demagogic powers of Hitler, Mussolini, and other dictators ([12], pp. 72-81). By the 1950s, the concept's power of explanation shifted toward non-European societies as the American thinkers primarily employed it to explain the emergence of new societies in post-colonial Asia and Africa ([12], pp. 81-86); but by the late 1960s a broadened and rather diluted version of the concept "charisma" established itself as one of the theoretical lenses that the American intellectuals used to view their own pluralistic society. In the sphere of religion it proved to be particularly helpful in efforts to explain the 1960s rise of the New Age spirituality, its gurus, and the American fascination with self-actualization. As Derman summed up his argument: "Max Weber found a place in American intellectual life because he proved himself useful for thinking with. He helped Americans articulate issues that mattered to them, address developments that loomed on their own social and political horizons" ([12], p. 88).

\section{Civic Faith in Baltimore}

The aim of my reflection is to focus on the twenty-first-century relevance of the concept of charismatic religious leadership in an American city, Baltimore, and, through it, other similar urban communities. Baltimore is home to about 620,000 inhabitants of whom about 64 percent are African American, about 32 percent White, and the rest mostly Latinos and Asian. The ethnic make-up of the city is not irrelevant to the question at hand, for especially among the American Black communities charismatic religious leadership functions as a gateway to civic authority [13]. This charismatic power is at times a matter of magnetism of a personal sort, but often the leader's inspired preaching and social relevance is attributed to the visionary, supernatural power that comes very close to Max Weber's prophetic understanding of the concept charisma.

From the American Black churches many civic leaders have emerged to play roles that reach well beyond the walls of their congregations, among them Martin Luther King, whose impassioned preaching at Dexter Avenue Baptist Church in Montgomery, Alabama, was a prelude to national and global civil rights leadership. Baltimore has had its share of visionary Black leaders who have united civil rights protests with prophetic preaching. Among the recent examples is Bishop John Richard Bryant, one of the national leaders of the African Methodist Episcopal (A.M.E.) church. His impassioned, Pentecostal, preaching helped the revive Baltimore's Bethel A.M.E. church during the 1970s, attract attention to the plight of the city's black workers, and eventually propelled him to a national fame. I shall below suggest that the ethnic dimension of charismatic authority is an important topic to identify. It closely connects with Baltimore's uneasy history with segregation and racially unequal access to established, institutional power, religious or secular. 
Another demographic feature of today's Baltimore is important to note as a backdrop to the question of charismatic religious authority. That is the city's struggle with poverty. The U.S. Census Bureau's most recent poverty estimate, published in Fall 2012, revealed that close to 25 percent of the city's inhabitants live below the federal poverty level [14]. Theirs are the neighborhoods of East and West Baltimore, plighted with urban violence and some of the country's worst public health crises that relate to alcohol and drug abuse, sexually transmitted diseases, substandard housing conditions, and chronic illnesses, such as Type II Diabetes, coupled with high incidence of cardiovascular diseases. Theirs are the formerly segregated African American neighborhoods, shaped by the city's discriminatory housing ordinances ([15], pp. 47-86). The educational and health disparities between the town's neighborhoods are reflected in the glaring findings concerning life expectancy and other indicators of population health: Baltimore's Neighborhood Health Profiles website, which contain a wealth of public health data about the city's various neighborhoods, demonstrates that life-expectancy between city's wealthy areas and its impoverished neighborhoods vary by twenty years in favor of the wealthy and well-educated [16]. The dark vision of the television series, Homicide and The Wire, both brainchildren of a former Baltimore Sun reporter David Simon, have made Baltimore's plight globally known. It has even prompted the city's former health commissioner, Peter Beilenson, to profile the city's public health challenges in the light of the gritty themes of The Wire [17].

The dramatic circumstances of poverty and daily fear of violence create a sense of social urgency characteristic of crisis - and breed intense expressions of faith. Prophetic preaching is not uncommon in these circumstances; it can even help the young to rise to early leadership. A documentary, The Boys of Baraka (2005), told the story of twenty-one boys from East Baltimore. All these at-risk youth were sent for a year to an experimental boarding school in Kenya. It is perhaps not surprising that one of the boys, De'von Brown, who seems to have successfully found his way out of the ghetto and is now a student at a local college, was also a fitness buff and a child preacher. The viewers of The Boys of Baraka follow De'von's life at his grandmother's home and then in Kenya. They are introduced to De'von's mother who shared her history of heroin addiction and, then, casually seated in a sofa and playing with her cell phone, invites De'von to demonstrate his inspired preaching. The rhythmic beat of the twelve-year-old's preaching quickly breaks sweat on his forehead and reduces his breathing to gasps of impassioned utterances. The boy's grandmother reveals that De'von wanted to be a preacher since he was three or four years old [18]. The promise of preaching may not mean much to children of wealth and stability but, as Kenyatta Gilbert has observed, impassioned preaching for civil rights or social change has been a catalyst towards a better future for many African Americans and their troubled communities ([19], pp. 10$15)$.

In Baltimore inspired preaching, Pentecostal expressions of faith-glossolalia, falling backward, and faith healing - and often authoritarian leadership have created several financially and politically powerful Black religious communities. Their leaders are consulted by politicians and community organizers; their support sought by both proponents and opponents of divisive issues such as The Affordable Care Act (2010) and gay marriage. Public health and social outreach organizations seek their partnership. One of these communities, Bethel A.M.E. in impoverished Druid Heights - the church lifted to its new glory by the above-mentioned John Richard 
Bryant - was featured in American Grace, Robert D. Putnam and David E. Campbell's massive sociological study of American faith communities ([20], pp. 195-211). On a Sunday they observed the "long pastoral performance, which builds steadily in intensity" ([20], p. 199) of the church's current and very popular leader, Reverend Dr. Frank Reid III. Many other of Baltimore's financially, politically, and communally successful urban Black mega-churches could have been featured, among them internet and technology savvy Empowerment Temple as well as New Psalmist Baptist Church, which on its website lists close to sixty focus areas or ministries as diverse as family wholeness, health empowerment, foreign outreach, and ministry to the deaf.

\section{Community Engagement through Inspired Preaching}

In all these communities, inspired preaching and personal charisma of the leader - and his wife, "the first lady" - is the glue that holds communities together and prompts involvement in worship in the people gathered together to glorify God. The power attained or given to one is consolidated in the enlivened collective response of the many. At a spirited service of often well over an hour, if not two or three, both the preacher and the congregants need a cloth to wipe off the sweat and tears. It appears that the intense energy generated at worship services is a way to recharge the social commitment, social Gospel, which is quintessential to the African American understanding of faith ([20], pp. 279-84). In this fashion the Black mega-churches of Baltimore can gather together a storm of support for social outreach or civil rights related political causes. Such was the case, for instance, in Spring 2012 in the Empowerment Temple when hundreds attended a service that brought together the parents of slain African American Florida youth, Trayvon Martin, and the temple's well-connected, charismatic pastor, Jamal Bryant. Many in audience wore hooded sweatshirts to commemorate the youthful outfit worn by Martin at the time of his death.

The strongly felt urban presence of the Black religious powerhouses would probably have a counter-cultural impact in a city where the African Americans are a minority. In Baltimore, however, where two-thirds of the population is African American, the charisma of the powerful faith leaders often arrives in support of secular leadership. Baltimore's current mayor, Stephanie Rawlings-Blake, for instance, shares this culture of close alliances between faith and civic leader. The visionary pastor of her church, Douglas Memorial Community Church, Sheridan Todd Yeary served in her mayoral transition team and is actively involved in urban policy.

One may wonder what exactly would Max Weber say about these types of alliances, common in Baltimore in which the powers of personally and religiously charismatic spiritual leaders significantly shape the communal and political affairs of the surrounding city? Might these serve as prime, modern, examples of the alignment of personal charisma of a religious leader and the institutional demands of the bureaucratic, elected officials? The question of Weberian charisma is further complicated by the dimension of "inherited," intergenerational leadership, for many of Baltimore's charismatic and socially powerful African American preachers are sons and/or grandsons of equally powerful religious leaders. For example, Jamal Bryant of the Empowerment Temple is the son of Bishop John Richard Bryant; Frank Reid III of Bethel A.M.E. Church is the son of Bishop Frank Reid, Jr.; Sheridan Todd Yeary is a "third-generation" preacher, as is stated in his biography the church's website. It appears that Max Weber's categories of visionary, charismatic leadership, as outlined in Gary Dickson's introductory article, are relevant but intermixed in the 
African American mega-churches of today's Baltimore. The prophetically powerful and politically charismatic leaders of the Black churches work in close collaboration with the city's elected officials, engage in urban civic issues of a broad range, and often embody generations of preaching expertise in service of challenging social issues facing today's American cities.

\section{African American Charismatic Women Leaders}

The civic relevance of Baltimore's religious leaders is not limited to the African American pastors of the mega-churches - nor is it limited to men. While the leaders of America's Black mega-churches are typically married men, and women's institutional leadership opportunities few, prophetic and civic religious leadership is a significant gateway to the African American women [21], the most religious population group of all Americans, as is indicated in The Washington Post and Kaiser Family Foundations 2012 poll of Black Women [22]. In Baltimore these religiously inspired, socially committed African-American women are the movers and shakers in their local communities. Their input is especially felt in the fields of social affairs and health care-they are the ones I often see when I follow the city's diverse faith communities and their involvement in urban health issues. Theirs are the Baltimore organizations such as Bernice Tucker's Women Accepting Responsibility and Debra Hickman's Sisters Together and Reaching, both especially focusing on women and HIV/AIDS. Among these women are pastors of smaller faith communities and storefront churches, which line the troubled blocks of Baltimore's Greenmount Avenue, for instance. Their contributions are significant in faith-based health and community events such as Transformation Explosion (August 2011), Days of Hope (Summers 2011 and 2012), and The City Uprising HIV/AIDS days $(2011,2012)$.

The issues that the women of faith deal with in the inner city of Baltimore involve the most daunting urban challenges - heroin and other drug addictions, HIV/AIDS and other sexually transmitted diseases, human trafficking, domestic violence, gangs. I have had the privilege to follow many of these women in action both in the streets of Baltimore and in prophetic, prayer revivals. Their leadership in inspired sermons, prayer, and Pentecostal healings is a match to the more publicly visible African American male preachers. These women's sermons lift the congregation from their seats. Moved by the spirit, the congregants, on their feet, shift their weight, dance, raise arms, and hop about. They support the ones whose feet tremble at the power of the emotion. Their praises fill the room with a symphony of affirmations, short utterances, sobs, clapping of hands, and clicking of the tongue. The women's sermons are often preludes to spiritual healing, resting in the spirit (falling back), and casting out spirits. The adjutants prepare for the moves of the spirit. Water jugs await the speaker to replenish herself; cloths for wiping the sweat from her brow are ready. Tissue boxes circulate among the congregants and white sheets are available for those who rest in the spirit at the front of the gathering. Of course, not all the worship gatherings reach to these heights, but female faith leaders of Baltimore certainly participate in the inspirational preaching that is characteristic to African American communities around the United States. These significant preaching contributions of the nation's Black women are reflected in their considerable presence in the Norton anthology of African American sermons, Preaching With Sacred Fire [23]. 
Yet, the economic ramifications of African American women's spiritual and social engagement in Baltimore's urban affairs often share one feature - the work does not benefit women financially. Virtually all the charismatic, Black female faith leaders, including the ones who don the title Reverend, earn their living elsewhere. Many of them appear to struggle with the same financial challenges than the people whom they serve or gather together in worship. Many a storefront church or a smaller faith community proudly displays the name of their female leader but it is not equally clear that the community is able to support its spiritual leader financially. The economic vulnerabilities associated with all spiritual endeavors may have its share in explaining the challenges that Black women leaders encounter. Their contributions and strong voices are needed in the struggling urban neighborhoods that continue to exist in the state of a sustained crisis. The city leaders and medical establishment, including Johns Hopkins Hospital, reach out to these women to establish partnerships with the surrounding community. Yet, women's charisma and communal commitment does not translate into economic stability or, much less, the financial rewards of some charismatic male spiritual leaders ([21], p. 66).

\section{Continuities from the Past}

There is more research to do, places to visit. While I currently have more questions than answers about Baltimore's urban religious culture and the place of health in it, it is striking how the conditions of economic struggle seem to perpetuate religious strategies that are many hundreds of years older than their modern circumstances. The sainted women of the late-medieval cities, the sante vive or living saints studied by Gabriella Zarri ([24], pp. 87-164), rose to fame with power of their prophetic, visionary experiences, and interwove their piety with the destinies of the people in need. The most noted of them, such as Catherine of Siena (1347-1380), successfully secured both popular and broad institutional recognition through her partnerships with other women, religious leaders, and secular rulers ([8], pp. 671-76).

The prophetic inspiration and holistically felt deep religious commitment toward the surrounding society continues to lift women to charismatic positions of leadership but not necessarily to financially and institutionally stable circumstances. These continuities demonstrate trajectories that intertwine opportunity with oppression. One of the continuing contradictions is particularly striking - the women's own physical suffering, sacrifices, coupled with their contributions toward the alleviation of the suffering of the others. Many medieval women rose to sanctity through a path that was paved with their own suffering and with the healing miracles done to others ([25], pp. 220-38). Many modern, urban African American woman rise to a position of community leadership by engaging in the promotion of health, even though they are part of an ethnic group that bears the burden of a broad range of health disparities, as has been demonstrated in several reports of the Centers for Disease Control and Prevention.

\section{Conclusions}

In conclusion, I would like to suggest that Max Weber's concept of charisma offers a helpful perspective or a tool to think with when seeking to understand the complex ways in which religion, authority, and social affairs interconnect in the context of a modern American city. Here I have focused on the particular example of Baltimore, its African American preachers, and their 
commitment to socially and politically engaged, often prophetic and Pentecostal, faith. The city is also a home to a large Catholic population; historic and culturally active mainline, mostly White, Protestant churches; Jewish congregations; and a growing Muslim population of immigrants from the Near East and Africa. These communities are actively engaged in the cultural affairs of the town and they too commit to urban outreach in multiple, comprehensive ways, including homeless shelters, soup kitchens, employment centers, and health care. Yet, their leaders do not seem to strive toward a similar mix of personal and prophetic charisma, local politics, and immersion in urban affairs as is characteristic of the involvement of the city's African American faith leaders. It seems that the magnetism of the African American preachers of either gender is still one of the most significant ways to instill a sense of spiritual and civic sense of the community in a twenty-first-century American city. This charismatic aspect of faith is necessary in mobilizing people for just causes, to fight against disease and for good health care, to demand decent housing, and to eradicate prejudice.

\section{Conflicts of Interest}

The author declares no conflict of interest.

\section{References}

1. "Religious Landscape Survey (2007)." PewResearch Religion \& Public Life Project. Available online: http://religions.pewforum.org/ (accessed on 12 March 2014).

2. Rik Pinxten, and Lisa Dikomitis. When God Comes to Town: Religious Traditions in Urban Contexts. New York: Berg Hahn Books, 2009.

3. Laurence Moore. Selling God: American Religion in the Marketplace Culture. New York: Oxford University Press, 1994.

4. Harvey Cox. The Secular City: A Celebration of its Liberties and an Invitation to its Discipline. New York: The Macmillan Company, 1966.

5. Robert Orsi, ed. Gods of the City: Religion and the American Urban Landscape. Bloomington: Indiana University Press, 1999.

6. Diana L. Eck. A New Religious America: How a "Christian" Country Has Become the World's Most Religiously Diverse Nation. New York: Harper Collins, 2001.

7. Maiju Lehmijoki-Gardner. Worldly Saints: Social Interaction of Dominican Penitent Women. Helsinki: Suomen Historiallinen Seura, 1999.

8. Maiju Lehmijoki-Gardner. "Writing Religious Rules as an Interactive Process: Dominican Penitent Women and the Making of Their Regula." Speculum 79 (2004): 660-87.

9. Maiju Lehmijoki-Gardner, ed. Dominican Penitent Women. New York: Paulist Press, 2005.

10. Health and Faith in Baltimore. Available online: http://www.healthfaithbaltimore.org/ (accessed on 12 March 2014).

11. Lawrence A. Scaff. Max Weber in America. Princeton: Princeton University Press, 2011, pp. 29-38, 161-80.

12. Joshua Derman. "Max Weber and Charisma: A Transatlantic Affair." New German Critique 38 no. 2 (2011): 51-88. 
13. Frederick C. Harris. "Black Churches and Civic Traditions: Outreach, Activism, and the Politics of Public Funding of Faith-Based Ministries." In Can Charitable Choice Work?: Covering Religion's Impact on Urban Affairs and Social Services. Edited by Andrew Walsh. Hartford: Pew Program on Religion and the News Media and the Leonard E. Greenberg Center for the Study of Religion in Public Life, 2001, pp. 140-56. Available online: http://www.trincoll.edu/depts/csrpl/Charitable\%20Choice\%20book/contents.htm (accessed on 28 November 2012).

14. "State \& County QuickFacts. Baltimore city, Maryland." U.S. Census Bureau. Available online: http://quickfacts.census.gov/qfd/states/24/24510.html (accessed on 12 March 2014).

15. Antero Pietilä. Not in My Neighborhood: How Bigotry Shaped a Great American City. Chicago: Ivan R. Dee, 2010, pp. 47-86.

16. "Neighborhood Health Profiles." Baltimore City Health Department. Available online: http://baltimorehealth.org/neighborhoodmap.html (accessed on 12 March 2014).

17. Peter Beilenson, and Patrick McGuire. Tapping into the Wire: The Real Urban Crisis. Baltimore: The Johns Hopkins University Press, 2012.

18. The Boys of Baraka [Documentary]. Directed by Heidi Ewing and Rachel Grady. New York: Loki Films, 2005, DVD.

19. Kenyatta Gilbert. The Journey and Promise of African American Preaching. Minneapolis: Fortress Press, 2011, pp. 10-15.

20. Robert D. Putnam, and David E. Campbell. American Grace: How Religion Divides and Unites Us. New York: Simon \& Schuster, 2010, pp. 195-211, 279-84.

21. Hans A. Baer. "The Limited Empowerment of Women in Black Spiritual Churches: An Alternative Vehicle to Religious Leadership." Sociology of Religion 54, no. 1 (1993): 65-82.

22. "The Washington Post and Kaiser Family Foundations 2012 poll of Black Women." The Washington Post. Available online: http:/www.washingtonpost.com/wp-srv/special/nation/ black-women-in-america/ (accessed on 12 March 2014).

23. Martha Simmons, and Frank A. Thomas, eds. Preaching with Sacred Fire: An Anthology of African American Sermons, 1750 to the Present. New York: W.W. Norton \& Co, 2010.

24. Gabriella Zarri. Le Sante Vive: Profezie di Corte e Devozione Femminile tra '400 e '500. Turin: Rosenberg \& Sellier, 1990, pp. 87-164 (In Italian).

25. Donald Weinstein, and Rudolph M. Bell. Saints and Society: The Two Worlds of Western Christendom, 1000-1700. Chicago: The Chicago University Press, 1982, pp. 220-38. 
MDPI AG

Klybeckstrasse 64

4057 Basel, Switzerland

Tel. +41616837734

Fax +41613028918

http://www.mdpi.com/

Religions Editorial Office

E-mail: religions@mdpi.com

http://www.mdpi.com/journal/religions 


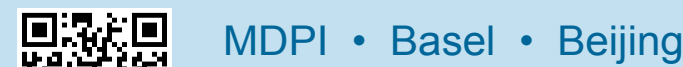

1S4 ISBN 978-3-03842-007-1

教教 www.mdpi.com 